\title{
DE KOLONIËN
}

\section{VAN DE MAATSCHAPPIJ} VAN WELDADIGHEID

$$
\text { (18 18-1859) }
$$

EEN LANDBOUWKUNDIG EN SOCIAAL-ECONOMISCH EXPERIMENT

J. D. DORGELO 
J. D. DORGELO

proefschrift: DE KOLONIËN VAN DE

MAATSCHAPPIJ VAN WELDADIGHEID (I 8 I 8 - I 859 )

\section{STELLINGEN}

I

De fundamentele oorzaak van de mislukking van de vrije landbouwkoloniën in financieel en landbouwkundig opzicht was gelegen in de discrepantie van bevolkingsgrootte en oppervlakte cultuurgrond, die zich manifesteerde in een te geringe bedrijfsomvang en een te sterk overwicht van de akkerbouw in het produktieplan.

Hoofdstukken III en IV van dit proefschrift.

I I

De meningsverschillen over de bedrijfsvoering, vooral ten aanzien van de rundveehouderij en de bremteelt, tussen de directie en deskundige bezoekers van de koloniën enerzijds en de theoreticus Joh. van den Bosch en de Permanente Commissie anderzijds vormen een bewijs voor de onjuistheid van de uitspraak van Westendorp Boerma, dat Van den Bosch een grote soepelheid aan de dag legde met betrekking tot de aanpassing van zijn plannen aan de veranderde omstandigheden.

Hoofdstuk IV van dit proefschrift; J. J. Westendorp Boerma, Johannes van den Bosch als sociaal hervormer; de Maatschappij van Weldadigheid, Groningen 1927.

I I I

In het belang van een efficiënt agrarisch structuurbeleid in de landen van de Europese Economische Gemeenschap dient de Commissie van de E.E.G. op korte termijn:

I. nadere richtlijnen op te stellen ten aanzien van de doelstelling en de inhoud;

2. voorstellen te doen ter bevordering van de coördinatie van dit structuurbeleid. 
Bij de samenstelling van regionale economische ontwikkelingsplannen voor de in 1959 door het Ministerie van Economische Zaken in Nederland aangewezen probleemgebieden is de coördinatie met het agrarisch structuurbeleid onvoldoende; in het belang van een harmonische ontplooiing van de produktiviteit en de welvaart in de verschillende bedrijfstakken is een juist samenspel noodzakelijk.

J. D. Dorgelo, Agrarisch structuurbeleid en regionale economische ontwikkelingspolitiek in West-Europa (III), in: Economisch-Statistische Berichten, 1961 no, $230 x$.

V

Het Ontwikkelings- en Saneringsfonds voor de Landbouw zal met de ten aanzien van de sanering voorgestelde uitvoeringsmaatregelen slechts een geringe bijdrage kunnen leveren tot de verbetering van de bedrijfsgroottestructuur.

VI

Een vigerend streekplan dient niet alleen de juridische grondslag te vormen voor de toekomstige ontwikkeling van de gebieden met een niet-agrarische bestemming, doch tevens het uitgangspunt te zijn voor bindende richtlijnen ter zake van een overheidsbeleid, dat is gericht op de verbetering van de agrarisch-economische structuur in de gebieden met een agrarische bestemming.

\section{I I}

De opvatting, dat de relatief ongunstige bedrijfsverkaveling op de zandgronden in de eerste plaats veroorzaakt is door de vererving van boerennalatenschappen, vindt onvoldoende steun in de resultaten van het historisch onderzoek; de wijze van ingebruikneming van de cultuurgrond is de belangrijkste factor, die het grondpatroon van de bedrijfsverkaveling heeft bepaald.

Een verdeling van de voorkeurssollicitanten voor landbouwbedrijven in de IJsselmeerpolders over de categorieën 
a. gedupeerden door niet-agrarische bestemming;

b. gegadigden uit ruilverkavelingsgebieden, in de verhouding $I: 2$, zoals toegepast bij de eerste uitgifte van bedrijven in Oostelijk Flevoland, betekent:

I. een relatieve onderwaardering van het algemeen belang ten aanzien van categorie a en

2. een niet optimale economische en sociale structuur in de nog te koloniseren IJsselmeerpolders.

I X

In de agrarische streekverbeteringsgebieden dient de overheid in het belang van de leefbaarheid van het platteland in dezelfde mate aandacht te besteden aan de verbetering van het maatschappelijk klimaat als in de probleemgebieden.

$\mathbf{X}$

De vermindering van het aantal leerlingen van de lagere landbouwscholen sedert 1954 is om meer dan één reden een gunstig verschijnsel.

\section{$\mathbf{X I}$}

Met het oog op de sterke samenhang tussen gezin en bedrijf in de Nederlandse landbouw kan de economisch-sociale voorlichting door de plattelandsorganisaties slechts dan een optimaal effect bereiken, indien deze organisaties financieel in staat worden gesteld ook buiten de streekverbeteringsgebieden door middel van individuele huishoudelijke voorlichting huishoud-economische voorlichting te verzorgen.

XII

De aanhang van de Vereniging voor Bedrijfsvrijheid in de Landbouw en van de Boerenpartij is mede veroorzaakt door een onvoldoende functioneren van de interne communicatie in de standsorganisaties. 

DE KOLONIËN VAN DE

MAATSCHAPPIJ VAN WELDADIGHEID

(I 8 I 8-I 859 ) 
Dit proefschrift met stellingen van

JAN DERK DORGELO,

landbouwkundig ingenieur, geboren te Rotterdam, I I september I925, is goedgekeurd door de promotor, Dr. B. H. Sucher van Batr, hoogleraar in de agrarische geschiedenis.

De Rector Magnificus der Landbouwhogeschool, W. F. ErJsvoogeL

Wageningen, 25 mei 1964 . 
NN 8201,367

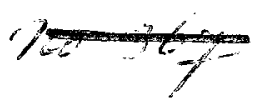

\section{DE KOLONIËN}

\section{VAN DE MAATSCHAPPIJ VAN WELDADIGHEID}

\section{(I 8 I 8 - I 8 59)}

Een landbouwkundig en sociaal-economisch experiment

\section{PROEFSCHRIFT}

ter verkrijging van de graad van doctor in de landbouwkunde, op gezag van de Rector Magnificus, Ir. W. F. Eijsvoogel, hoogleraar in de hydraulica, de bevloeiing,

de weg- en waterbouwkunde en de bosbouwarchitectuur, te verdedigen tegen de bedenkingen van een commissie uit de Senaat van de Landbouwhogeschool te Wageningen op woensdag 17 juni 1964 te 16 uur door

\section{JAN DERK DORGELO}


PROMOTOR: DR. B. H. SLICHER VAN BATH

\author{
MPUPTHE

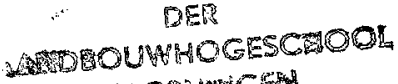 \\ 46 G
}


AAN MIJN VROUW

AAN MIJN KINDEREN 


$$
\text { - }
$$




\section{WOORD VOORAF}

Ter gelegenheid van de voltooiing van mijn studie aan de Landbouwhogeschool wil ik gaarne dank brengen aan U, Hoogleraren en OudHoogleraren, voor Uw andeel in mijn wetenschappelijke opleiding. Met name denk ik hier aan de betekenis van Uw onderricht, Hooggeleerde Hofstee, voor mijn latere werkkring.

In het bijzonder betuig ik mijn grote erkentelijkheid aan U, Hooggeleerde Slicher van Bath. Door Uw colleges is mijn belangstelling voor de geschiedenis van het platteland en de landbouw aangewakkerd. U bent mij steeds ter wille geweest bij de bepaling van de vormgeving van mijn „,hobby”, die uiteindelijk resulteerde in dit geschrift. Voor Uw leiding en raadgevingen ben ik $U$ dankbaar. Het is mij een voorrecht dat $U$ de neerslag van mijn onderzoek als proefschrift hebt willen aanvaarden en als mijn promotor wilt optreden.

Door mijn vroegere werkkring in de provincie Drenthe als wetenschappelijk medewerker van de afdeling Streekonderzoek van het Landbouw-Economisch Instituut ben ik gestuit op het onderwerp van dit proefschrift. Gaarne zeg ik U, Dr. Visser, Hoofd van deze afdeling van het L.E.r., dank voor de welwillende medewerking en belangstelling, die ik van Uw zijde heb mogen ondervinden.

Voor de totstandkoming van deze dissertatie was een diepgaande archiefstudie noodzakelijk. Gaarne maak ik hier melding van de bereidwilligheid van het College van Commissarissen van de Maatschappij van Weldadigheid, dat mij in staat stelde het archief van de Maatschappij te Frederiksoord te bestuderen. U, Ir. Wessels, direkteur van de Maatschappij, hebt mij vele dagen (en avonden) toegang verschaft tot dit archief, verscheidene waardevolle gegevens verstrekt en het manuscript willen doorlezen.

Grote medewerking mocht ik ook ondervinden van de heer Drs. E. J. Werkman, Rijksarchivaris in Drenthe, bij het onderzoek van de vele handschriften, die behoren tot het oud archief van de Maatschappij 
van Weldadigheid, dat thans berust in het Rijksarchief in de Provincie Drenthe te Assen.

Bijzonder erkentelijk ben ik U, Dr. Van der Poel, voor Uw bereidheid de inhoud van het manuscript kritisch te bezien. Vele waardevolle adviezen heb ik aan $U$ te danken.

Voorts dank ik allen, die, op welke wijze dan ook, aan dit onderzoek hebben medegewerkt.

Ten slotte spreek ik op deze plaats mijn dank uit tot mijn vrouw en mijn moeder, die steeds grote belangstelling hebben getoond voor mijn studie. Ondanks haar onophoudelijke zorg voor ons gezin heeft mijn vrouw voortdurend meegeleefd met de ontwikkeling van dit proefschrift. De steun, die zij heeft gegeven, is voor mij van grote waarde geweest. 


\section{INHOUD}

HOOFDSTUK I Inleiding en probleemstelling . . . . . . . . . . . . . . . . I

I. De armoede in Nederland omstreeks 1815 . . . . . . . . I

2. De landbouw in Drenthe omstreeks 1815 . . . . . . . . 4

3. Oprichting, doelstellingen en functie van de Maatschappij van Weldadigheid . . . . . . . . . . . . . . 8

4. De bevolking van de vrije koloniën . . . . . . . . . . 17

5. Probleemstelling . . . . . . . . . . . . . . 19

H OOFDST u K II De cultuurgrond in de vrije koloniën . . . . . . . . . . . . . 22

I. Verwerving van grondbezit . . . . . . . . . . . 22

2. Bodemgesteldheid en ontginning ...... . . . . . $3 \mathrm{I}$

H O OFDSTUK III Enkele economische aspecten van de agrarische structuur . . . . . . 41

I. Waterbeheersing . . . . . . . . . . . . . . 4I

2. Bedrijfsgroottestructuur . . . . . . . . . . . . 43

3. Ruimtelijke ligging en verkavelingstoestand . . . . . . . $4^{8}$

4. Ontsluiting . . . . . . . . . . . . . . 52

5. Pachtverhoudingen . . . . . . . . . . . . 55

6. Bedrijfsgebouwen en woningen ............. 6 I

HO OFDSTUK IV Het produktieplan en de bedrijfsvoering . . . . . . . . . . . . . 65

I. Aard van het grondgebruik . . . . . . . . . . . 65

2. Het bouwland . . . . . . . . . . . . . . 78

a. De mestroorziening . . . . . . . . . . . . . . 79

b. De vruchtwisseling . . . . . . . . . . . . . . 107

c. De opbrengst der gewassen . . . . . . . . . . . . . I 19

3. Het grasland en de veestapel . . . . . . . . . . . . 136

4. De bosbouw . . . . . . . . . . . . . . . . 151 
H O OFDSTUK V Enkele sociale aspecten van de landbouwkoloniën. . . . . . . I55

I. Arbeidsverhoudingen in de landbouw . . . . . . . 155

2. Niet-agrarische werkgelegenheid ......... . 165

3. Het onderwijs. . . . . . . . . . . . . . . . 169

H O OFDSTuK vi Samenvatting en conclusies; overzicht van de ontwikkeling na 1859. . 174

I. Verwerving van grond en ontginning . . . . . . . 174

2. Produktie-omstandigheden . . . . . . . . . . I76

3. Bedrijfstype en bedrijfsvoering . . . . . . . . . . . . I79

4. Arbeidsverhoudingen ............. . 183

5. Conclusies . . . . . . . . . . . . . . . . 184

6. Overzicht van de ontwikkeling na $1859 \ldots \ldots$. . . . I 88

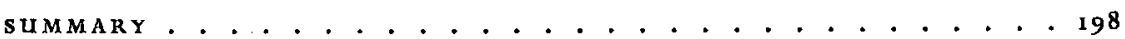

BIJLAGEN . . . . . . . . . . . . . . . . . . 20I

AANTEKENINGEN. . . . . . . . . . . . . . . . . . . 213

GERAADPLEEGDE LITERATUUR EN ARCHIEFSTUKKEN . . . . . . . . 226 


\section{INLEIDING EN PROBLEEMSTELLING}

\section{DE ARMOEDE IN NEDERLANDOMSTREEKS I 8 I 5}

$\mathrm{D}$ E uitgebreide literatuur over de sociaal-economische situatie in ons land ten tijde van en na de Franse overheersing toont duidelijk aan, dat het aantal behoeftigen destijds een omvang had, die wij ons tegenwoordig niet meer voor kunnen stellen. Volgens Witlox heerste in Europa reeds sedert het begin van de 18 de eeuw een "Zeitalter des Pauperismus", dat in 18 I $_{5}-1_{3} 8_{3}$ zijn hoogtepunt tegemoet ging. $\mathrm{Na}$ Spanje en Engeland was in Nederland de werkloosheid het grootst, terwijl ons land tevens naar verhouding het grootste aantal bedelaars telde ${ }^{\mathrm{I}}$.

Men gebruikte destijds de cijfers betreffende het aantal geheel of gedeeltelijk bedeelde armen om de omvang van de armoede aan te geven. Uiteraard vormen deze gegevens slechts een globale maatstaf: de z.g. stille armoede komt hierin immers niet tot uitdrukking. Johannes van den Bosch, die het initiatief heeft genomen tot de oprichting van de Maatschappij van Weldadigheid, noemde voor geheel Europa een aantal armen van niet minder dan 16 miljoen omstreeks 18 I 5 . In procenten van de bevolking bedroeg het aantal armen $50 \%$ in Spanje, $15-20 \%$ in Groot-Brittannië en Ierland en $9 \%$ in de Verenigde Nederlanden. In Frankrijk was dit percentage vóór de revolutie 5 , in 18 I 5 aanzienlijk hoger. Hoewel de toestand in Nederland dus relatief gunstig was, telden de Noordelijke Nederlanden 190.000 bedeelde armen, de Zuidelijke Nederlanden 300.000.

Volgens een schatting van Van den Bosch waren I42.000 armen in Noord-Nederland geschikt om te werken. Hieronder bevonden zich naar zijn berekening 50.000 bedelaars en 20.000 tijdelijk noodlijdenden ${ }^{2}$.

Deze armlastigen woonden vooral in de steden. Westendorp Boerma vermeldt, dat in Amsterdam in de winter van 1798 op 1799 niet minder dan $41 \%$ van de inwoners werd bedeeld, in 1805 zelfs $50 \%{ }^{3}$. In laatstgenoemd jaar was dit percentage voor 's-Gravenhage I 3, Haarlem en 
Rotterdam i 7, Hoorn en Leiden 25, Delft 33. In I 8 I 8, toen Van den Bosch zijn eerste verhandeling publiceerde, behoorde in Amsterdam en Hoorn een derde gedeelte, in Leiden de helft van de inwoners tot de bedeelden.

Hierbij is op te merken, dat de prijzen van de levensmiddelen vooral in de jaren $1805 / 06$ en 18 1 8 relatief zeer hoog waren. Op de goederenbeurs te Amsterdam behaalde de Koningsberger tarwe in deze drie jaren een gemiddelde jaarprijs van resp. $f_{486,79}, f_{525}$, - en $f_{418} 8,60$ per last. Het gemiddelde over de periode 172 I-45 bedroeg $f$ 144,60. Ten opzichte van de prijzen van $1790-94$ was de gemiddelde prijs over de jaren I 805-09 bijna tweemaal zo hoog, in de periode I815-1819 bijna $50 \%$ hoger 4 .

Het is duidelijk, dat de hoge kosten van levensonderhoud in de genoemde jaren een stijging van het aantal bedeelden ten gevolge hadden.

Ten plattelande was de toestand naar de mening van de meeste schrijvers minder nijpend. Zo was in Gelderland en Noord-Brabant de verhouding tussen het aantal behoeftigen en het inwonertal het minst ongunstig. Wel was de bedelarij op het platteland zeer verbreid, hetgeen aanleiding was tot het houden van drijfjachten op bedelaars door de z.g. "bedeljagers". In een provinciestad als Purmerend waren in I 8 I 5 ongeveer 80 beroepsbedelaars, in $18 \mathrm{I}$ in Amsterdam en in $181 \mathrm{~g}$ in Rotterdam ruim $800^{3}$. Betrokken op het inwonertal was het aantal bedelaars in Purmerend echter groter dan in Amsterdam, nl. 5,3 resp. $0,4 \%{ }^{5}$.

Ook Van den Bosch gaf te kennen, dat in vele streken in Gelderland, Overijssel en Noord-Brabant geen enkel bedeeld gezin woonde. Ten plattelande kwamen relatief minder armen voor dan in de „rijke” steden, aldus Van den Bosch. Wel maakte hij melding van seizoenonderstand op het platteland ${ }^{6}$.

In het midden latend in welke mate arme plattelandsbewoners zich in de steden vestigden, is het waarschijnlijk, dat de mogelijkheid door enig grondgebruik en veehouderij in de eerste levensbehoeften te voorzien de oorzaak was van de geringe waarneembare armoede in de plattelandsgebieden. De harde noodzaak zich te wenden tot weldadigheidsinstellingen was dan ook ten plattelande minder frequent aanwezig. Evenwel is het niet uitgesloten, dat, met name in de zandgebieden, omstreeks de Franse tijd meer gezinnen in behoeftige omstandigheden verkeerden, dan uit de cijfers omtrent het aantal bedeelden is af te leiden.

Verberne stelt duidelijk, dat het pauperisme in de jaren omstreeks I 8 r 8 geen stedelijk verschijnsel was. „Ook het platteland kende vreselijke toestanden. Getuigenissen van tijdgenoten bewijzen het". Hij haalt 
enkele uitspraken aan van de eigenaar van een landgoed onder Zundert uit I 8 I $7^{7}$.

Van den Bosch was van mening, dat de armoede, voor zover deze voortvloeide uit een te geringe werkgelegenheid, hoofdzakelijk een gevolg was van de onevenredige eigendomsverdeling. Een betrekkelijk kleine groep particuliere personen had de produktiemiddelen kapitaal en grond in bezit, hetgeen z.i. ook gold voor de landbouw. Bij een gelijkmatiger verdeling van het grondbezit verwachtte hij meer werkgelegenheid, doordat het aantal landbouwpaarden kleiner en het aantal mensen, in de landbouw werkzaam, groter zou zijn. Aldus kon de landbouw in deze omstandigheden meer produkten voortbrengen voor een grotere bevolkingsgroep. Van den Bosch pleitte niet voor een nationalisatie van de cultuurgrond, omdat in landen met staatseigendom van de grond (hij noemde als voorbeeld Oost-Indië) vele andere gebreken bestonden. Het ging hem alleen om het aanduiden van de oorzaak van de armoede door onvoldoende werkgelegenheid8.

Op grond van deze theorie en de latere gang van zaken in zijn schepping, de landbouwkoloniën der Maatschappij van Weldadigheid, hebben sommige auteurs Van den Bosch socialistische of communistische opvattingen toegeschreven. Inderdaad is het begrijpelijk, dat hij in de ogen van zijn tijdgenoten min of meer revolutionaire gedachten verkondigde. Het waren de in sociaal-economisch opzicht zeer ongunstige maatschappelijke verhoudingen, die de directe aanleiding vormden tot het ontstaan van Van den Bosch' zienswijze. Op zichzelf waren zijn denkbeelden zeker niet onjuist. Men gaat m.i. te ver, wanneer men hem beticht van communistische ideeën in de thans gangbare betekenis.

Ook Ameshoff was de mening toegedaan, dat de armoede verband hield met de verdeling van eigendom of het verschil tussen de standen. "Naast rijkdom woont gebrek". Nergens was het standsverschil z.i. zo gering als in Drenthe, waar ondanks vele arme ingezetenen het gebrek minder bekend was dan in andere provincies. Men kon zich door arbeid het nodige verschaffen. Wel waren er veel "seizoenbedeelden”, vooral in de veengebieden ${ }^{\mathrm{I}}$.

Naast de onevenredige eigendomsverdeling noemde Van den Bosch als oorzaken van de armoede door te weinig werkgelegenheid nog de wisseling in de betrekkingen tussen naburige landen, zoals oorlogen en handelsbelemmeringen. Naar zijn mening speelde ook de smaak van het publiek een rolı ${ }^{\mathrm{I}}$.

Een recente schrijver als Witlox komt tot de conclusie, dat de oorzaak van de grote werkloosheid rond 18 I 5 was gelegen in het onvruchtbare 
commerciële en rentenierskapitalisme, de achteruitgang van de handel, de depressie in de nijverheid, de misoogsten in de landbouw en de bevolkingstoeneming sinds de tweede helft van de. I 8 de eeuw ${ }^{\mathrm{I}}$.

Slicher van Bath heeft nader uiteengezet, dat vrijwel overal in WestEuropa na I $75^{\circ}$ door een complex van oorzaken een langdurige en sterke bevolkingsgroei optrad. Hij noemt in dit verband de verlaging van de huwelijksleeftijd in samenhang met de tot omstreeks 1760 gunstige economische omstandigheden, de daling van de sterfte, in het bijzonder de kindersterfte, en de langere levensduur. De produktie paste zich aanvankelijk aan door een uitbreiding in de industriële en de agrarische sector. Ook vermeerderde de geldhoeveelheid 13 .

Blijkbaar nam de werkgelegenheid echter in het algemeen onvoldoende toe om de groeiende bevolking een redelijk bestaan te kunnen bieden. In ons land begon het tijdperk van de industrialisatie eerst in de tweede helft van de rgde eeuw. Deze divergentie van bevolkingstoeneming en groei van de werkgelegenheid is te beschouwen als de hoofdoorzaak van het armoedeverschijnsel omstreeks i 8 I 5 . Deze ontwikkeling spitste zich in de Franse tijd nog aanmerkelijk toe door de sterke vermindering van de bedrijvigheid in de scheepvaart, handel en nijverheid in verband met de oorlogsomstandigheden. Van 1760 tot \pm r 805 stegen de graanprijzen in Overijssel en op de Amsterdamse graanmarkt met ongeveer $100 \%$, terwijl de geldlonen niet veel veranderden.13. Ook het levensniveau van de werkende beroepsbevolking is derhalve in Nederland gedurende en na de Franse tijd niet bepaald rooskleurig geweest. Als algemene conclusie kan men stellen, dat de sociaaleconomische omstandigheden voor het Nederlandse volk bijzonder veel te wensen overlieten. De herboren Verenigde Nederlanden gingen gebukt onder een structurele economische depressie, die wellicht in latere tijden zonder weerga is geweest.

\section{DE LANDBOUW IN DRENTHE OMSTREEKS I 8 I 5}

Op de Drentse zandgronden is de landbouw steeds als gemengd bedrijf beoefend. De oude bouwlanden lagen op de essen bij de dorpen. De oppervlakte bouwland was afhankelijk van het areaal natuurlijk grasland langs de stroompjes. Dit grasland bepaalde nl. de omvang van de rundveestapel, die op haar beurt via de mestproduktie weer de beperkende factor was voor het areaal bouwland. Hoewel de mesthoeveelheid door het gebruik van heideplaggen als strooisel sterk werd vergroot, had deze handelwijze slechts ten dele een toeneming van de bemestingskracht ten 
gevolge, namelijk alleen op langere termijn ten aanzien van het humusgehalte van het bouwland ${ }^{\mathrm{I} 4}$.

De essen waren verdeeld in vele kleine akkers, waarvan elke boer een aantal in gebruik had, verspreid over de es. Men verbouwde voornamelijk rogge en boekweit, in westelijk Drenthe ook in tamelijke hoeveelheden vlas, dat werd verhandeld op de jaarmarkten. Volgens de beschrijving van Van Lier (1795) werden ook aardappelen "hier in eene zeer grote menigte verbouwd". Als gewassen vermeldde hij tevens nog haver en hennep ${ }^{15}$.

Ameshoff noemde ook de gerst en de teelt van spurrie of "spar", die soms na de roggeoogst werd uitgezaaid als groenbemestingsgewas en veevoer. Het belang van de verschillende gewassen blijkt uit zijn opgave van de verdeling over het bouwland in $\%$ :

$\begin{array}{lr}\text { rogge } & \mathbf{6 7} \\ \text { boekweit } & \text { I4 } \\ \text { aardappelen } & \text { 10 } \\ \text { haver } & \mathbf{8} \\ \text { gerst } & \text { I }\end{array}$

Gerst en haver brachten minder op dan de behoefte. Boekweit had veel last van nachtvorst en natte en koude zomers. Naast de rogge en aardappelen was de boekweit het voornaamste voedsel. De oogst van rogge en aardappelen overtrof de behoefte, zodat van deze produkten werd uitgevoerd naar Holland en elders (Groningen) ${ }^{16}$.

Ook te Vledder was de roggeoogst in normale jaren omstreeks 18 Io voldoende voor de eigen behoefte. De opbrengst was omstreeks driemaal de uitzaai, soms vier- of vijfmaal. De haveroogst bedroeg meestal vijfmaal, de boekweitoogst vijftienmaal de uitgezaaide hoeveelheid ${ }^{7}$. De opbrengst van rogge en haver was volgens deze gegevens te Vledder relatief gering in vergelijking tot de door Van der Poel uit de antwoorden op de enquête van I 800 berekende cijfers voor Almelo en Etten (N-B). Hij vond voor rogge en haver gemiddeld resp. 6-7 en 6-1 3 maal de hoeveelheid zaaizaad ${ }^{18}$.

Als vruchtwisseling op de esgronden vindt men doorgaans het drieslagstelsel vermeld: $\mathrm{I} / 3$ wintergraan, $\mathrm{I} / 3$ zomergewas en $\mathrm{I} / 3$ braak ${ }^{\mathrm{I} 9}$. Von Grouner deelde echter omstreeks 1822 mede, dat de rogge door de boeren in de omgeving van Frederiksoord sedert eeuwen op hetzelfde land werd verbouwd zonder enige braak, maar steeds bemest, zodat men altijd een goed gewas verkreeg20. Men mag aannemen, dat Ameshoff en 
Von Grouner de werkelijkheid dichter benaderden ten aanzien van het areaal wintergraan.

Een bijzondere teelt werd gevormd door de cultuur van veenboekweit op plaatsen, waar hoogveen voorkwam. $\mathrm{Na}$ begreppelen van deze grond om de afwatering te bevorderen werd het veen met de hak bewerkt en in het voorjaar gebrand. In de as zaaiden de boeren zonder enige andere bemesting de boekweit, die dikwijls een goede oogst opleverde. $\mathrm{Na}$ een periode van 7 à 8 jaar boekweitteelt liet men de grond weer een aantal jaren braak liggen ${ }^{15}$.

Het grasland langs de beken en riviertjes was volgens Ameshoff zeer schraal en van slechte kwaliteit. Een oppervlakte van 2 morgen $(=\mathrm{I}, 7$ ha) leverde niettemin als weiland voldoende voedsel op voor drie runderen, wanneer hooi en spurrie werd bijgevoerd. ${ }^{16}$ Deze dichte veebezetting stond in verband met het feit, dat het rundvee klein van stuk was en fijn gebouwd. De hooilanden werden 's winters onder water gezet (bevloeid) met behulp van stuwen. In het voorjaar zorgden de boeren voor een tijdige ontwatering, waarna zij zonder bemesting op een matig goede hooioogst konden rekenen. Omdat het water zoet was en zonder slib, achtte Von Grouner de bemestende werking betrekkelijk gering ${ }^{20}$.

Enige uitvoer had ook plaats van rundvee, vette varkens en boter (via Meppel). Kaasmakerij kwam weinig of niet voor. De Drentse boeren hielden destijds veel schapen om de mest, de wol en het vlees. Een deel van de wol werd uitgevoerd naar Kampen, Leiden en Frankrijk. De paardenfokkerij was, ook voor de handel, niet onaanzienlijk. Friese handelaren kochten wel Drentse paarden om ze als Friese paarden naar Holland door te verkopen. De bijenteelt was eveneens van belang. Ook uit Friesland werden bijenvolken op de heide gebracht ${ }^{21}$.

De bedrijven waren omstreeks 1800 doorgaans 40-50 mudden groot (=13-15 ha), terwijl de veestapel per boerderij bestond uit ongeveer 4 paarden, 20 stuks groot- en kleinvee en 150 schapen. Alle schapen van een dorp (16-20 boerderijen) stonden onder de hoede van één scheper, die soms belast was met de zorg voor 2000 dieren. Overdag werd de kudde geweid op de uitgestrekte heide; in de herfst liet men de schapen 's nachts op het bouwland tussen losse hekken en touwwerk voor de mestvoorziening'22.

De eigengeërfde boeren waren in de zandgebieden per dorp verenigd in de z.g. marken. Deze organisaties waren niet alleen eigenaars van de woeste gronden en enig bos, de brinken in de dorpen en de landbouwwegen, maar hadden ook het recht verordeningen vast te stellen met betrekking tot het grondgebruik. In de meeste dorpen bepaalde de 
marke de eerste oogstdag om te voorkomen, dat de boeren elkaar overlast zouden aandoen en ter bespoediging van de z.g. "gemene weide" op het bouwland na de oogst.

Elke eigenaar van aandelen in de marke kon zijn gedeelte van de heide afgezonderd krijgen in particuliere eigendom, indien hij, eventueel met anderen samen, twee volle aandelen ("waardelen") bezat. Dit recht van scheiding was bij de wet toegekend ${ }^{23}$.

Men maakte hiervan echter slechts weinig gebruik, omdat de ontginningsmogelijkheden gering waren. Bij het begin van de I gde eeuw was in Drenthe nog $68 \%$ van de grond in woeste toestand aanwezig, terwijl het bos slechts enkele procenten besloeg24. Kops wees in I 806 in een uitvoerige memorie op de noodzaak van verdeling van de woeste markegrond in het belang van de ontginning. In $1809 \mathrm{kwam}$ een wet tot stand, die bepaalde, dat de gemene gronden na een meerderheidsbesluit konden worden verdeeld onder de rechthebbenden. Ook deze mogelijkheid is weinig toegepast wegens de hoge verkavelingskosten, het gebrek aan kapitaal voor de ontginning en het mesttekort. Sinds I 8 I 2 kon de regering vrijstelling van grondbelasting verlenen gedurende 30 jaren na de ontginning 25 .

In het algemeen nam omstreeks 1800 de belangstelling voor de landbouw toe. Slicher van Bath schetst deze ontwikkeling als volgt: „Tal van uitvindingen op het gebied van de landbouwwerktuigen werden gedaan, groot was de belangstelling voor nieuwe landbouwmethoden. De literatuur op het gebied van de landbouw bloeide. Er werden genootschappen gevormd van personen, die belang stelden in de landbouw. De geboorte van de landbouwwetenschap valt in de tweede helft van de $18 \mathrm{de}$ eeuw. De geestdrift voor de landbouw in deze eeuw is hartverwarmend, maar men miste vaak nog de wetenschappelijke basis. De landbouwwetenschap ontplooide zich eerst ten volle in de i gde eeuw." En verder: "Zelden is wellicht de afstand tussen theorie en praktijk zo groot geweest als bij de landbouw in de 18 de en gedeeltelijk nog in de i gde eeuw." De theoretici publiceerden velerlei „lumineuze ideeën" in boeken en vlugschriften, die veelal nimmer werden verwerkelijkt, hoogstens door enkele grootgrondbezitters, „terwijl de boeren ongelovig en afkeurend toekeken" 26 . 
De gedachten van generaal Van den Bosch, die hebben geleid tot de oprichting van de Maatschappij van Weldadigheid, kunnen in hun oorsprong niet aan hem worden toegeschreven. Weliswaar stelt Westendorp Boerma, dat „het ontwerp en de ontwikkeling van het plan geheel afkomstig zijn van Van den Bosch"27, maar voordat hij zijn ideeën in de openbaarheid bracht, hadden reeds verscheidene personen in binnen- en buitenland soortgelijke voorstellen gedaan ter bestrijding van de armoede.

Zo haalde De Beaufort het verhaal aan van de Engelsman Joseph Marshall, die in $177^{\circ}$ een reis had gemaakt door de Verenigde Provinciën. Hierin noemde Marshall de ontginning van de heide bij Tilburg door de oud-officier Rey, die hiertoe arbeiders uit de Pfaltz, wellicht oudsoldaten, had aangetrokken. Volgens Rey zou het aanzien van Overijssel, Gelderland en Brabant in weinige jaren geheel zijn veranderd, indien de Staten-Generaal konden besluiten arme Duitse gezinnen over te brengen naar de woeste gronden. Marshall had dergelijke gedachten ook aangetroffen in een omstreeks 1770 te Amsterdam verschenen boek, waarvan hij de schrijver niet noemde: de regering kon alle woeste grond tot cultuurgrond maken door 40.000 gezinnen over te brengen en $f 5^{\circ}$ miljoen in het project te investeren. De gemeenschappelijke eigendom van de heide stond de uitvoering echter in de wege 28

Van den Bosch ontvouwde zijn plannen in zijn eerdergenoemde verhandeling, gepubliceerd in I8I8. Hij was van mening, dat de ondersteuning van de armen door liefdegiften schadelijk was voor de samenleving. Als gevolg hiervan nam volgens hem de luiheid toe, terwijl tevens het aantal armen groter werd. Naar zijn schatting schonk men in de Noordelijke en Zuidelijke Nederlanden per jaar ongeveer $f$ r 5 miljoen aan de armen. Dit geld diende men te besteden aan het verschaffen van arbeid door kolonisatie. Van den Bosch verbond hieraan onmiddellijk de bedoeling woelingen in de maatschappij te voorkomen ${ }^{29}$.

Hij was zich ervan bewust, dat de kolonisatie met drie belangrijke moeilijkheden te kampen zou krijgen. In de eerste plaats de opleiding van de armen tot arbeidzame kolonisten, vervolgens noemde hij de verwerving van de benodigde oppervlakte woeste grond en tenslotte de aantrekking van voldoende kapitaal ter financiering van het project. Van den Bosch meende dan ook, dat zekerheid ten aanzien van het welslagen van de onderneming niet kon worden gegeven: „de ondervinding, en deze alleen, kan hieromtrent uitspraak doen"30. Hij beval een proef 
aan met 75 tot 100 gezinnen, waarvoor $f 50.000$, - tot $f 60.000$, nodig zou zijn.

Onder het hoofd „Financiering van de Inrigting” stelde hij voor een jaarlijkse contributie te heffen van de deelnemers, die in vier klassen kon variëren van $f 4^{\circ}$, - per jaar gedurende 5 jaren tot $f 6,5^{\circ}$ per jaar gedurende 25 jaren. Bovendien zou men de leden kunnen verplichten tot bepaalde bedragen per jaar in de koloniën vervaardigde sajet, garen en linnen af te nemen. Van den Bosch ging er blijkbaar van uit, dat de regering niet in de financiering zou deelnemen. De op te richten maatschappij zou dus een vereniging van particulieren zijn. In plaats van uitkering van rente wilde de generaal zelfs de leden verzekeren tegen armoede, gekoppeld aan een weduwen-, wezen- en ouderdomsverzekering met de mogelijkheid van plaatsing in de koloniën. Hierdoor zou ook het eigenbelang van alle Nederlanders worden geprikkeld.

Van den Bosch was wel sterk doordrongen van het inzicht, dat een gezamenlijke aanpak van het armoedeprobleem noodzakelijk was. Op deze grondslag bouwde hij een conceptie, die zeker een revolutionaire ommekeer betekende in de armenzorg van de jaren rond i 8 I 5 !

Niettemin, ondanks zijn gematigd optimisme over de uitslag van het experiment, "geenszins zou daardoor de oorzaak der armoede in de toekomst zijn weggenomen”. De oorzaak was z.i. een „onvermijdelijk gevolg onzer maatschappelijke inrigtingen".

Als belangrijke nevenfunctie van de op te richten maatschappij zag Van den Bosch voorts de opvoeding van de kinderen van de kolonisten voor de gewone samenleving, waarbij vooral het onderwijs van veel gewicht was.

De Maatschappij van Weldadigheid begon gestalte te krijgen door de vorming van een Provisionele Commissie van Weldadigheid, waarschijnlijk tegen het einde van i 8 1 7. Van deze commissie was Van den Bosch president; als secretaris trad op prof. P. van Hemert te 's-Gravenhage, oud-hoogleraar in de letteren en wijsbegeerte te Amsterdam. Beide heren stelden een voorwoord samen, gedateerd 14 januari 18 I 8 , bij het Reglement voor de Maatschappij van Weldadigheid, dat in maart 1 818 op grote schaal werd verspreid ${ }^{3} \mathrm{r}$. Men kan aannemen, dat de Maatschappij feitelijk definitief is opgericht in maart 1818 , hoewel men later I april I 8 I 8 als de oprichtingsdatum heeft vastgesteld.

Uit het reglement blijkt, dat alle Nederlanders lid konden zijn. Nieuwe leden dienden echter te worden voorgedragen door reeds lid zijnde personen, terwijl de toetreding de goedkeuring van het bestuur behoefde. De doelstelling van de organisatie is in artikel 8 als volgt 
omschreven : „Het doel der Maatschappij is hoofdzakelijk, om den toestand der armen en lagere volksklassen te verbeteren, door zoodanige ontwerpen, die voor dezelve dienstig geoordeeld worden, ter uitvoering te brengen, inzonderheid door aan dezelve arbeid, onderhoud en onderwijs te verschaffen, en hen uit dien toestand van verbastering, waartoe deze menschen, in het algemeen, vervallen zijn, optebeuren, en tot eene hoogere beschaving, verlichting, en werkdadigheid op te leiden."

Artikel to voegde hieraan toe: „Het onderhoud, dat den armen verschaft wordt, zal alléén gegeven worden in vergelding van arbeid, en nimmer zal men trachten dit oogmerk door liefdegiften te bereiken." Men beoogde dus niet alleen werkverschaffing, maar tevens onderwijs en opvoeding tot bruikbare burgers, die in hun eigen bestaan konden voorzien. Was het streven economisch gericht voor wat betreft het bieden van werkgelegenheid, de sociale motieven waren primair. Men kan terecht spreken van een sociaal-economische doelstelling, uitgaande van een particulier initiatief.

In juni 1818 ging het bestuur van de Maatschappij over van de Provisionele op de definitieve Commissie van Weldadigheid, die als hoofdbestuur optrad. De Commissie van Weldadigheid bestond uit de volgende personen:

Prins Frederik (voorzitter), tweede zoon van Koning Willem I ;

Generaal-majoor Joh. van den Bosch, 's-Gravenhage (assessor);

Prof. Joh. Kinker, Luik (assessor), filosoof en literator;

P. J. Ameshoff, Amsterdam;

Mr. J.C. Faber van Riemsdijk, 's-Gravenhage, advocaat en adjunctburgemeester, belast met de armenzorg;

Mr. J.F.H. van Hemert, Amsterdam, advocaat;

Prof. P. van Hemert, 's-Gravenhage;

Prof. J. M. Kemper, Leiden;

J. Mendes de Leon, Amsterdam;

Jac. G. van Nes, lid Staten-Generaal;

Dr. C. Nieuwenhuis, Amsterdam, arts;

Prof. J. M. Schrant, Gent;

Mr. T. Sijpkens, Groningen, advocaat en lid Staten-Generaal.

De tien laatstgenoemde leden droegen de titel van directeur.

Het dagelijks bestuur over de Maatschappij kwam te berusten bij de Permanente Commissie, bestaande uit Van den Bosch, voorzitter, P. van Hemert, secretaris, en Faber van Riemsdijk, lid. De leden van de Maatschappij konden alleen invloed uitoefenen op de gang van zaken door 
de uit 24 personen bestaande Commissie van Toevoorzigt, waarvan de leden door kiesmannen werden gekozen. Laatstgenoemde commissie controleerde de rekening en verantwoording en zond jaarlijks een kleine inspectiecommissie naar de landbouwkoloniën om de toestand te onderzoeken.

De leden van de Maatschappij van Weldadigheid werden verenigd in afdelingen, die werden bestuurd door z.g. subcommissies van weldadigheid. Hierin waren zowel het plaatselijk bestuur, de geestelijkheid en de aanzienlijke burgerij als het eventueel aanwezige garnizoen vertegenwoordigd. Verscheidene garnizoenen hadden een eigen militaire subcommissie.

In april I8I9 telde de Maatschappij reeds 21.187 leden, die waren verdeeld over 657 subcommissies, 9 provinciale commissies in de Zuidelijke Nederlanden, 2 individuele leden en de Permanente Commissie. Tot I april I 8 I 9 was aan contributies $f 55.368$, - en aan giften $f_{1} 6.144,83 \frac{1}{2}$ ontvangen ${ }^{32}$. In afwijking van vroegere plannen van Van den Bosch was de jaarlijkse contributie per lid vastgesteld op minimaal $f 2,60$ of vijf cent per week.

Ten aanzien van de nieuw te ontwikkelen middelen van bestaan heeft Van den Bosch in een tweede verhandeling, geschreven in 1819 en in het Frans gepubliceerd in $182 \mathrm{r}$, aangegeven, dat deze aan drie voorwaarden moesten voldoen ${ }^{33}$ :

I. de levensmiddelenproduktie diende door het project toe te nemen; door voortbrenging van andere goederen zouden in de desbetreffende takken van nijverheid werkzame mannen werkloos kunnen worden;

2. de aan het werk gezette armen moesten in staat zijn door hun arbeid in hun behoeften te voorzien;

3. de armen dienden op de een of andere wijze te kunnen worden gedwongen tot werken, omdat morele verbetering nodig was in verband met de langdurige invloed van de armoede op hun geestesgesteldheid.

Op grond van deze overwegingen is Van den Bosch tot de conclusie gekomen, dat de stichting van landbouwkoloniën op heidegrond het enige juiste middel was, gecombineerd met spinnerij en weverij om in de eigen behoeften aan textiel te voorzien. De datum van 25 augustus I 8 I 8 , toen de eerste steen van de eerste kolonistenwoning door Van den Bosch te Frederiksoord werd gelegd, is de feitelijke stichtingsdatum van de landbouwkoloniën ${ }^{34}$.

De eerste aankoop van onroerend goed, het landgoed Westerbeeksloot in de gemeente Vledder, werd geheel gefinancierd met een lening van 
$f 56.000,-35$. Niet alleen voor de grondaankopen was veel geld nodig, maar ook voor de vestiging van de kolonistengezinnen. De Maatschappij becijferde de totale installatiekosten per gezin (woning, inventaris, grond, ontginning, voorschot) op $f_{1} 700$, - , welk bedrag de subcommissies en ook de gemeentebesturen over 16 jaar konden aflossen met een annuïteit van $f$ I 25, - Hiermee kregen zij het recht tot plaatsing van één gezin op één bepaalde hoeve, die na 16 jaar onbezwaard vruchteigendom van de contractant zou zijn, echter onder toezicht van de Maatschappij. Deze vestigingskosten moest de Maatschappij voorschieten ${ }^{36}$.

In de behoefte aan liquide middelen werd voorzien door een reeks leningen. De eerste, onder hypothecair verband op de koloniën I en II te Frederiksoord, bedroeg $f 80.000$,- - De volgende leningen zijn zonder verdere zekerheidsstelling afgesloten.

In de z.g. vrije of gewone koloniën te Frederiksoord en omgeving vestigden zich niet alleen behoeftige gezinnen. Ook bestond de mogelijkheid individuele personen, w.o. weeskinderen, naar deze koloniën op te zenden. Sedert 1822 is de Maatschappij zich tevens bezig gaan houden met de bestrijding van de bedelarij door bedelaars op te nemen in het gesticht bij de Ommerschans in Overijssel en één der te Veenhuizen in noordelijk Drenthe gebouwde gestichten. De twee andere gestichten te Veenhuizen zijn bevolkt met weeskinderen, vondelingen en andere verlaten kinderen, een klein aantal arme gezinnen en gezinnen van oudgedienden van leger en marine. Omdat de ontwikkeling van de landbouw bij de gestichten of dwangkoloniën buiten het bestek van deze studie valt, wordt ook aan de financiering van deze instellingen voorbijgegaan ${ }^{37}$. Hier zij volstaan met de opmerking, dat vooral deze gestichten hebben bijgedragen tot de latere financiële tekorten van de Maatschappij van Weldadigheid, die ontstonden na I 827 en in 1834 ongeveer $f_{3,5}$ miljoen beliepen.

Intussen genoot de Maatschappij in brede kring een grote belangstelling. Omstreeks begin 1823 bracht Koning Willem 1 voor de tweede maal een bezoek aan de koloniën ${ }^{38}$. Ook in het buitenland trokken de activiteiten van de Maatschappij veel aandacht. In I 822 heeft Von Grouner, die vanuit Beieren een studiereis maakte door de Nederlanden, een gedetailleerd onderzoek ingesteld in de landbouwkoloniën. Hij was toen reeds vol lof over hetgeen tot stand was gebracht: „Es giebt wohl kein wohlthätigeres Institut und keines, welches mit so geringen Mitteln so grosses zu leisten vermöchte!" Indien de goede geest van de beginjaren zou blijven heersen, „dann wird es in wenigen Jahren keine wichtigere 
und keine segenreicher Colonie auf der Erde geben, als die ArmenColonie Freederiks-Oord!" 39

Het ledental van de Maatschappij ontwikkelde zich evenwel niet zo gunstig, als de oprichters hadden gehoopt. In 1819 bereikte men een totaal van 22.478 leden, in de volgende jaren trad reeds een vermindering in, die zich vrijwel onafgebroken heeft voortgezet tot 9666 leden in 1833 . Als oorzaken gaf de Maatschappij zelf aan de welvaartsvermindering ten plattelande in de jaren twintig, de watersnoodramp in I 825 en de onvoldoende ijver van sommige subcommissies. Onder de 9666 leden in 1833 bevonden zich \pm 2000 militairen $^{40}$.

Niettemin sprak Martinet in I $83^{\circ}$ van „Deze koloniën, welke welligt de belangrijkste staat- en landhuishoudkundige onderneming onzer eeuw zijn ......" ${ }^{41}$.

In I 834 nam het ledental weer iets toe tot boven de 10.000 . De eerstvolgende jaren bleef het om dit aantal schommelen. In 1836 bestond het uit42 :

$\begin{array}{lr}\text { militairen } & 1498 \\ \text { bij de Permanente Commissie } & \\ \text { ingeschreven } & 36 \\ \text { andere leden in Nederland } & 7200 \\ \text { leden in Oost-Indië } & 65^{8} \\ \text { Suriname } & 168 \\ \text { Curaçao } & 41 \\ \text { Sint Eustatius } & 99 \\ \text { Totaal ledental } & 9610\end{array}$

De Permanente Commissie verzond in $18{ }_{3} 8$ een rondschrijven aan de Gouverneurs der Provinciën, waarin werd aangedrongen op hun medewerking ter vergroting van het antal leden. Ook in Drenthe had deze actie succes: bij de subcommissie te Assen waren in I $84^{\circ}$ ingeschreven als lid I $x 2$ personen op een bevolking van 2394 zielen. In deze verhouding zou de Maatschappij over het gehele land meer dan r 00.000 leden kunnen hebben. In het Financieel Verslag over 1839 verklaarde de Permanente Commissie: „Met genoegen vestigen wij er de aandacht op, dat niet alleen in de hoofdplaats van Drenthe, maar ook in schier al de overige plaatsen van eenig aanzien in dat gewest, de deelneming aan het lidmaatschap een' algemeenen bijval heeft gevonden. Men is toch dáár meer dan elders in de gelegenheid de bijzonderheden onzer stichtingen van nabij te beoordeelen, en het schijnt, dat de vooroordeelen, welke op meer verwijderde plaatsen 
tegen onze Maatschappij nog bestaan, en ons somwijlen worden tegen geworpen, als de opwekking tot belangstelling in den weg te staan, aldaar geen grond vinden."

Inmiddels waren de financiële moeilijkheden van de Maatschappij zo toegenomen, dat het bestuur in 1842 aftrad. De regering, die door eerder afgesloten contracten over de opzending van bedelaars naar de gestichten financieel direct belanghebbende was geworden, benoemde in dit jaar een Staatscommissie, die rapport uitbracht. Dit resulteerde in een nieuw contract tussen regering en Maatschappij in I 843, waarna het bestuur weer in functie $\mathrm{kwam}^{43}$. Om bezuinigingsredenen besloot men de plaatsing van nieuwe gezinnen in de koloniën, op grond van de door de subcommissies afgedragen contributies, tijdelijk tot 1844 op te schorten. 44

Het aantal leden van de Maatschappij bewoog zich in de jaren veertig weer in dalende lijn. Zo bedroeg het volgens het financieel verslag over 1845 in dit jaar 7843 personen. Daarom wendde de Permanente Commissie zich wederom tot de Gouverneurs der Provinciën met het verzoek mede te werken aan pogingen de slapende subcommissies tot leven te brengen. Als gevolg hiervan is in $r 848$ voor het eerst sinds jaren weer sprake geweest van een kleine toeneming van het ledental. Onder andere de subcommissie te Assen werd in het financieel verslag over I 849 weer genoemd als één van de meest actieve afdelingen.

Het is waarschijnlijk, dat de financiële problemen van de Maatschappij mede de verminderde belangstelling in de hand werkten. Dit wil echter niet zeggen, dat men zich in het algemeen weinig interesseerde voor de armoedebestrijding. De discussie over dit onderwerp duurde nog steeds voort. Een voorbeeld van de talrijke geschriften over de armoedebestrijding door kolonisatie uit deze jaren is de brochure van Van den Bergh van 1845 . Hij besprak de mogelijkheden in het binnenland, elders in Europa en overzee en gaf aan de eerstgenoemde de voorkeur. Zelfs stelde hij een plan op, dat in grote trekken met het initiatief van Van den Bosch overeenkwam, zij het dan met een minder straffe inrichting van de koloniën en minder kosten.

De koloniën van de Maatschappij van Weldadigheid beoordeelde Van den Bergh als volgt: „Hoe doorwrocht en diep doordacht het plan des Graven Van den Bosch scheen, de ondervinding heeft niet in allen deele aan de verwachting beantwoord en de ondernemers van verdere pogingen afgeschrikt. Het is bekend, dat de koloniën van nijverheid in Overijssel bij den landman en burgerstand in zekere minachting geraakt zijn, zoodat zij het als eene schande aanzien, iemand hunner derwaarts te zien zenden. Dit komt daar van daan, dat er bedelaars en allerlei straat- 
volk daar opgenomen worden, waarmede de eerlijke man zich niet wil gelijk stellen"45. Zoals meermalen gebeurde, maakte ook Van den Bergh geen onderscheid tussen de bedelaarsgestichten en de vrije koloniën, ofschoon in de laatstgenoemde geen bedelaars werden opgenomen.

De bekende filantroop Heldring was eveneens een voorstander van kolonisatie, maar dan in het bijzonder in Oost-Indië en Noord-Amerika. Hoewel hij zich niet uitsprak tegen de Maatschappij van Weldadigheid, was Heldring het niet eens met het uitgangspunt, dat ook stedelingen landwerk zouden kunnen doen. De Maatschappij had z.i. te weinig gelet op de validiteit van de kolonisten. Heldring kwam tot de volgende uitspraak: „Onze Koloniën van Weldadigheid kosten millioenen schats, terwijl de eene helft der bevolking in de bedelaars-koloniën niet eens als man en vrouw in eigen huisgezin mag zamenwonen, en de andere op gronden moet zwoegen, die niet meer waard zijn dan de mest, die er jaarlijks gebragt wordt, die duizenden schats kosten en niet dan met onnoemelijke onkosten kunnen staande gehouden worden"46.

Toch heeft Heldring gedacht aan de oprichting van een nieuwe maatschappij voor ontginning en vrije kolonisatie van arme plattelandsbewoners, de z.g. één - cent - daags - maatschappij. In $185^{\circ}$ bracht Heldring aan het Nederlandsch Landhuishoudkundig Congres hierover verslag uit namens een in 1846 ingestelde commissie 47 . Omdat de levensmiddelenprijzen inmiddels waren gedaald en de aankoop van heide door „kapitalisten” voor ontginning toenam, oordeelde men de oprichting van een dergelijke maatschappij niet meer nodig. Wel was de Commissie voorstander van plaatsing van arme stadskinderen als bestedelingen op boerderijen. Van de Maatschappij van Weldadigheid werd in het verslag niet gerept.

Eveneens uit 1850 dateert de volgende uitspraak:

„... de oprigting der koloniën van weldadigheid (heeft) tot eene den lande millioenen schats kostende en daarbij mislukte proeve van armenwerkverschaffing gevoerd; terwijl de verhouding der armen tot de overige bevolking, althans van I 822-I $83 \mathrm{I}$, en derhalve in het tijdperk, dat de geroemde goede maatregelen goede vruchten hadden moeten gaan dragen, van I op i I, tot I op 9 was geklommen"48.

Uit deze enkele citaten blijkt duidelijk, dat de Maatschappij van Weldadigheid omstreeks het midden van de 19 de eeuw in een crisisperiode verkeerde. Het grote enthousiasme van de oprichtingsjaren had plaats gemaakt voor soms scherpe kritiek, die veelal niet ongerechtvaardigd was. De Permanente Commissie verflauwde echter niet in haar pogingen de Maatschappij meer weerklank te doen vinden. Als gevolg van een in 
augustus $185 \mathrm{I}$ verzonden circulaire kon men ruim 2300 nieuwe leden inschrijven. De feitelijke toeneming van het aantal leden van einde $185^{\circ}$ tot einde $\mathrm{I} 852$ bedroeg volgens de financiële verslagen evenwel niet meer dan ruim 900 , doordat velen hun contributie slechts eenmaal betaalden.

De meerdere ontvangsten uit de contributies wilde de Maatschappij bestemmen voor uitbreiding van de kolonisatie in de gewone koloniën. Inderdaad zijn in I 853/54 nog I I nieuwe kolonistenwoningen gebouwd, terwijl alle hoeven bezet waren 49 .

Dit was niet meer dan een stuiptrekking. In 1854 was een schuldconversie nodig om de zekerheid van rentebetaling te vergroten. De aanzienlijke lopende schuld werd omgezet in gevestigde schuld; voor een gedeelte hiervan werden rente en aflossing door Prins Frederik gegarandeerd. De Permanente Commissie zag zich het volgende jaar wederom genoodzaakt de regering te verzoeken om financiële steun. De situatie werd onderzocht door een tweede Staatscommissie. Deze adviseerde tot scheiding van gestichten en vrije koloniën: de Staat zou de gestichten in onbezwaarde eigendom en vrij gebruik over kunnen nemen, evenals de tegen $4 \%$ gevestigde schuld met een nieuwe rentevoet van $3 \%$, terwijl de door Prins Frederik gegarandeerde schuld à pari zou worden afgelost.

Het bestuur van de Maatschappij aanvaardde dit voorstel niet en trad einde 1856 voor de tweede maal af. Overeenkomstig het contract van I 843 werd het beheer over de koloniën overgenomen door een regeringsgecommitteerde, die er niet in slaagde een nieuw bestuur samen te stellen. Een groep leden van de Maatschappij vormde vervolgens in 1857 een commissie van zes leden "tot het voorstaan van de belangen der maatschappij". Deze onderhandelde met de Staatscommissie-1 855 over een definitieve regeling en bereidde een interne reorganisatie voor.

De uiteindelijke overeenkomst met de regering en de nieuwe statuten zijn op r I en I 2 maart I 859 goedgekeurd door een vergadering van afgevaardigden te Amsterdam. De overeenkomst tussen Maatschappij en regering bevatte de volgende punten:

1. de gestichten kwamen in volle eigendom aan de Staat (incl. de nog woeste gronden te Veenhuizen);

2. de vrije koloniën te Frederiksoord en omgeving bleven in volle eigendom aan de Maatschappij;

3. de regering keerde aan de Maatschappij $f 3.650 .000,-$ in contanten uit ter betaling van alle schulden. De aandeelhouders in de leningen werd $65 \%$ uitgekeerd 43 .

De Maatschappij van Weldadigheid, die nog slechts ongeveer 3000 leden 
telde ${ }^{50}$, ging zich voortaan beperken tot de het eerst gestichte gewone koloniën. Het nieuwe bestuur verklaarde in een circulaire tot het Nederlandse volk, dat de vermindering van het ledental en de giften vooral was veroorzaakt door de bedelaarsverzorging, de grote Rijkssubsidies en het toezicht van de regering. De Maatschappij was in de periode tot 1859 „allengs bijna geheel ontaard in een staatsarmbestuur" ${ } 51$.

\section{DE BEVOLKING VAN DE VRIJE KOLONIËN}

De gezinnen, die zich in de vrije koloniën vestigden, waren zeer overwegend afkomstig uit de grote en kleine steden en van huis uit met de landbouw onbekend. In 1819 was de eerste kolonie te Frederiksoord (kolonie I) met zijn 52 woningen geheel bewoond. De gezinnen bestonden gemiddeld uit 6,5 personen. Meer dan de helft was uit de westelijke provincies gekomen, nl. I4 gezinnen uit Noord-Holland, I 2 uit Zuid-Holland en 3 uit Utrecht. Vanuit Gelderland en Overijssel hadden zich ro gezinnen in de kolonie gevestigd, uit de noordelijke provincies 7 gezinnen, waarvan slechts I gezin uit Drenthe (Assen). Ten slotte waren 5 gezinnen uit Zeeland overgekomen ${ }^{52}$.

Men kan aannemen, dat ook in latere jaren het merendeel van de kolonisten werd geplaatst vanuit de westelijke provincies en de steden. Westendorp Boerma constateert dan ook terecht: „Voor Drenthe betekende de Maatschappij een hoofdzakelijk Hollandse mensengroep ter grootte van $10 \%$ van de eigen bevolking" 53 .

In I 824 was het aantal bewoners van de vrije koloniën gestegen tot \pm $224^{\circ}$ personen, waarvan in 1825 omstreeks 900 gevestigd waren in de gemeente Vledder, terwijl de oorspronkelijke bevolking van deze gemeente buiten de koloniën slechts bijna 700 zielen telde, hoofdzakelijk gezinnen van kleine boeren en arbeiders. Men sprak van de "oude gemeente" en de „kolonie”, waartussen destijds een vrijwel absolute scheidslijn bestond 54 .

De kinderen van de kolonisten mochten niet in de koloniën trouwen en zich daar blijvend vestigen. $\mathrm{Zij}_{\mathrm{ij}}$ moesten deze verlaten en elders een bestaan zoeken. Men kan aannemen, dat dit laatste vaak moeilijkheden zal hebben opgeleverd. Hierin vonden de tegenstanders van de koloniën volgens Von Grouner hun sterkste argument ${ }^{55}$. Z.i. kon men echter wel een oplossing vinden door de koloniën uit te breiden, zodat de kinderen hun ouders konden opvolgen of een eigen hoeve gaan bewonen. Een dergelijke aanvulling op de wijze van kolonisatie oordeelde Von Grouner vroeger of later nodig. Introuwen van kolonistenkinderen was alleen 
toegestaan, indien het echtpaar zijn intrek nam bij één der ouders en deze weduwe of weduwnaar was. Het oogmerk van de Maatschappij was, dat het aantal gezinnen in de koloniën niet door huwelijk zou vermeerderen 56 .

Uitbreiding van de vrije koloniën heeft na I 824 vrijwel niet meer plaats gehad, zodat ook het aantal inwoners ophield toe te nemen. Het nam zelfs af tot 2145 personen eind 1827 . Weliswaar overtrof in deze jaren, zoals blijkt uit de Algemeene Verslagen, het aantal nieuw opgenomen kolonisten het aantal, dat al dan niet op eigen verzoek was ontslagen, terwijl ook het geboortencijfer groter was dan het sterfteciffer. Deze positieve verschillen werden echter meer dan opgeheven door het aantal "gedeserteerden", dat steeds aanmerkelijk groter was dan het aantal „van desertie terug".

In I 829 nam de Maatschappij een besluit omtrent het verlenen van verlof aan kolonistenkinderen om zich een bestaan buiten de koloniën te zoeken. Op verzoek van de ouders kon z.g. groot verlof voor drie maanden worden gegeven aan kinderen, die "genoegzaam volwassen en voor hun eigen onderhoud geschikt en in staat schijnen te wezen", indien de belangen van het gezin hun vertrek toestond. Waren zij na drie maanden niet teruggekeerd, dan werden zij als ontslagen beschouwd, tenzij verlenging van het verlof met een zelfde periode was gevraagd. De Maatschappij ging het vertrek van de jongelui bevorderen door te bemiddelen bij aanvragen om personeel57. Het is niet gebleken, dat de Maatschappij eigener beweging plaatsingsmogelijkheden ging zoeken en/of beoordelen.

Bij het Algemeen Verslag over 1830 is in tabel B een overzicht opgenomen van de bestemming van de kinderen, die de koloniën in dit jaar hebben verlaten. Deze gegevens zijn samengevat in onderstaande tabel. Hieruit blijkt, dat de variatie in de beroepskeuze niet groot was.

Tabel I - BEROEPEN VAN DE IN I 830 ONTSLAGEN KOLONISTENKINDEREN

\begin{tabular}{lcccccc}
\hline & & \multicolumn{5}{c}{ Aantal kinderen met beroep } \\
\cline { 3 - 7 } & $\begin{array}{c}\text { Aantal } \\
\text { ontslagen }\end{array}$ & militair & $\begin{array}{c}\text { dienst- } \\
\text { knecht, } \\
\text { dienstbode }\end{array}$ & $\begin{array}{c}\text { land- } \\
\text { arbeider, } \\
\text { boerenmeid }\end{array}$ & $\begin{array}{c}\text { M.v.W. } \\
\text { beambte }\end{array}$ & $\begin{array}{c}\text { dienstbode } \\
\text { in } \\
\text { koloniën }\end{array}$ \\
\hline Jongens & 248 & 174 & 13 & I I & 3 & - \\
Meisjes & 81 & - & 36 & 7 & - & 2 \\
\hline
\end{tabular}

Bron: Algemeen Verslag over 1830. 
Inmiddels nam de bevolking van de koloniën vanaf I 828 gestadig toe tot omstreeks 2400 kolonisten in \pm 480 gezinnen in de jaren 1835 en I 836 . In verband met ingevoerde bezuinigingsmaatregelen namen in I 836 tot en met 1838 vele kolonisten ontslag uit de koloniën. Zo b.v. in 1837 zelfs 249 personen, terwijl er 2 I 7 werden opgenomen. Tevens nam het aantal deserties toe: in 1838 zijn 70 personen weggelopen. De inspectiecommissie adviseerde meer tevredenheid op te wekken door het houden van feesten en vermakelijkheden overeenkomstig het oorspronkelijke plan ${ }^{58}$. Op I januari r 839 telden de koloniën nog 2 135 kolonisten-inwoners, dus bijna evenveel als in 1827 .

Gedurende de volgende twintig jaren nam het inwonertal weer betrekkelijk regelmatig toe. Het bereikte zijn grootste omvang op I januari I 856 met bijna 2800 kolonisten in ongeveer $55^{\circ}$ gezinnen. Hierna is het aantal zielen verminderd.

In de eerste jaren van kolonisatie zijn de te plaatsen gezinnen door de subcommissies geselecteerd op voldoende werklust en "werkvatbaarheid". Naderhand zijn echter vele minder valide mensen naar de koloniën gezonden, die niet in staat waren door eigen arbeid geheel in hun onderhoud te voorzien. Vanzelfsprekend bevonden zich onder de kolonisten ook velen, die wel konden, maar niet wilden werken. Deze omstandigheden hebben tot tal van moeilijkheden geleid59.

Omstreeks $193^{\circ}$ beschreef een criticus de gang van zaken bij de kolonisatie in de eerste tientallen jaren op de volgende wijze: „de koloniën (werden) een toevluchtsoord voor alle wrakhout der maatschappij, dat de verschillende afdelingen, gedreven door misplaatsten weldadigheidszin of ter ontlasting van armbesturen en diaconieën, konden opduikelen"60. Eilerts de Haan verklaarde daarentegen in 1872 , als ooggetuige, dat men zich dikwijls een verkeerd beeld heeft gevormd van de bevolking van de vrije koloniën door deze op één lijn te stellen met de bedelaars in de gestichten. Volgens hem waren vele bewoners van de vrije koloniën „veel beschaafder dan het gros hunner naburen in de omliggende dorpen" 6 .

\section{PROBLEEMSTELLING}

In de voorgaande paragrafen is uiteengezet, onder welke omstandigheden de Maatschappij van Weldadigheid het levenslicht aanschouwde. Het project van Johannes van den Bosch voorzag in de stichting van een aantal landbouwkoloniën en was voortgekomen uit de maatschappelijke situatie in de Verenigde Nederlanden na de Franse tijd. Kenmerkend voor de 
jaren omstreeks I 8 I 5 was enerzijds de overstelpende armoede, veroorzaakt door een groot tekort aan werkgelegenheid, met name in de steden, en anderzijds de sluimerende potentie van de uitgestrekte heidevelden in de zandprovincies, die nog vrijwel niet werden beroerd door de activiteiten van de ontginners.

Van den Bosch heeft op zijn wijze de toenmalige sociaal-economische verhoudingen geanalyseerd. Bij afwezigheid van een overheidsbeleid ten aanzien van de armoede oordeelde hij het noodzakelijk, dat het particulier initiatief zich door middel van de Maatschappij van Weldadigheid ging beijveren om kapitaal te vergaren ter investering in de ontginning van woeste gronden en aansluitende vestiging van landbouwkoloniën. Arbeid was in voldoende mate aanwezig in de talrijke stedelijke paupers. Door deze met hun gezinnen over te brengen naar de koloniën kon men deze mensen produktieve werkgelegenheid bieden in de verwachting, dat zij door arbeid in de eigen behoeften zouden kunnen voorzien.

De landbouw op de zandgronden had destijds op traditionele wijze plaats als gemengd bedrijf, in haar ontwikkeling geremd door mestgebrek. De onverdeelde heidegronden waren gemeenschappelijk eigendom van de boeren. Verdeling onder de rechthebbenden had nog weinig zin en kwam dan ook vrijwel niet voor. De nieuwe denkbeelden, verkondigd door een aantal theoretische "landbouwdeskundigen", vonden in de praktijk weinig of geen weerklank met uitzondering van enkele grootgrondbezitters, die sommige vindingen op hun bedrijven toepasten.

In het bestuur van de Maatschappij van Weldadigheid hadden geen praktische landbouwers zitting. Ook Van den Bosch putte zijn landbouwkundige kennis vooral uit de literatuur, grotendeels afkomstig van buitenlandse schrijyers. Hij zag zich echter gesteld voor de taak zijn kennis van de landbouw in praktijk te brengen in de koloniën.

In het licht van het voorgaande doemen enkele vraagtekens op, die de landbouwhistoricus belang inboezemen en in de volgende probleemstelling zijn samen te vatten:

I. Hoe is de Maatschappij erin geslaagd de benodigde woeste gronden in eigendom te verwerven en deze vervolgens te ontginnen?

2. Van welke aard waren de produktie-omstandigheden, waarin de landbouw in de koloniën is uitgeoefend? Men kan in dit verband denken aan de waterbeheersing, de bedrijfsgrootte, verkaveling en ontsluiting, en de toestand van bedrijfsgebouwen en woningen;

3. Welk bedrijfstype heeft de Maatschappij in de koloniën geïntroduceerd? Men had in dit opzicht de keus tussen het gemengde bedrijf van de omgeving der koloniën en hiervan afwijkende bedrijfstypen. 
In het bijzonder de oplossing van het bemestingsvraagstuk op de ontgonnen cultuurgrond kan moeilijkheden hebben opgeleverd;

4. Is het de Maatschappij gelukt de van oorsprong stedelijke kolonisten op te leiden tot landbouwers? Hoe waren de pacht- en arbeidsverhoudingen tussen de Maatschappij en de kolonisten geregeld?

$\mathrm{Bij}$ de beantwoording van deze agrarisch-historische vragen is, naar de tijd gezien, enige beperking noodzakelijk gebleken. Deze is gevonden door de literatuur- en archiefstudie, waarop de nu volgende hoofdstukken zijn gebaseerd, vooral te richten op de periode van I 8 I 8 tot 1859 en als object de z.g. vrije koloniën te Frederiksoord, Willemsoord en Wilhelminaoord te kiezen, aangevuld met het aangrenzende gebied van het Instituut voor den Landbouw te Wateren. Het genoemde tijdvak strekt zich uit van de stichting van de eerste landbouwkolonie te Frederiksoord tot de reorganisatie van de Maatschappij van Weldadigheid, waarbij de gestichten te Ommerschans en Veenhuizen zijn afgescheiden van de vrije koloniën.

Uit landbouwhistorisch oogpunt gezien is de eerste helft van de I gde eeuw tevens het meest aantrekkelijk, omdat de agrarische geschiedschrijving over deze decennia nog betrekkelijk weinig licht heeft kunnen doen schijnen. Men dient zich er evenwel van bewust te zijn, dat in de koloniën van de Maatschappij van Weldadigheid de theoretische z.g. "verlichte" landbouw tot leven is gebracht. Deze studie geeft derhalve in het algemeen geen beeld van de landbouw, zoals deze destijds werd uitgeoefend door de oorspronkelijke boerenbevolking in de omgeving van de landbouwkoloniën. 


\section{DE CULTUURGROND IN DE VRIJE KOLONIËN}

\section{VERWERVING VAN GRONDBEZIT}

TET stond Van den Bosch reeds bij de oprichting van de Maatschappij 1 van Weldadigheid duidelijk voor ogen, dat hij bij de uitvoering van zijn project een aantal grote moeilijkheden zou moeten overwinnen. Hij noemde ook met name de verkrijging van de benodigde grote oppervlakte grondr.

Hoewel in de Noordelijke Nederlanden destijds heide-, broek- en duingronden lagen tot een gezamenlijke oppervlakte van $\pm 750.000 \mathrm{mg}^{2}$, die geen bijzondere eigendom waren, achtte Van den Bosch het moeilijk hiervan vruchtbare cultuurgrond te maken. Een bezwaar was reeds, dat men wegens de gemeenschappelijke eigendom van deze gronden met een groot aantal eigenaren moest onderhandelen om tot een koopovereenkomst te geraken. Ten einde zich nader te kunnen oriënteren over de aanwezige mogelijkheden zond de Commissie van Weldadigheid enkele leden uit haar midden op inspectiereis. Zij bezochten in 18 I 8 de provincies Groningen, Friesland, Drenthe en Overijssel3. Eén der reizigers, P. J. Ameshoff, stelde de bevindingen op schrift en concludeerde: „Bij eene rigtige behandeling en de toereikende verschaffing van de noodige middelen heeft men geene mislukking te duchten, vooral niet in Drenthe, waar alles schijnt zamen te lopen om eenen goeden uitslag te verzekeren"4.

Deze voorkeur voor Drenthe was niet alleen gebaseerd op de gezonde lucht, maar ook op het overwegend voorkomen van het "vereenigd boerenbedrijf" (het gemengde bedrijfstype), waaraan Ameshoff blijkbaar veel waarde hechtte: "Vee is toch de grondslag van de landbouw". In verband met de mestroorziening in die tijd zeker een juist oordeel! Een ander argument ten gunste van Drenthe was de privaateigendom van alle woeste grond5. Men adviseerde overigens aan te vangen met een proefkolonisatie op reeds bebouwde grond. De kolonisten waren dan in staat 
direct in hun onderhoud te voorzien en konden later, met beter resultaat en meer lust, meer grond ontginnen.

Het advies van Ameshoff c.s. mondde dan ook uit in de aanbeveling volledige landbouwbedrijven aan te kopen, zo mogelijk een geheel gehucht. Eventueel zou men ook kunnen volstaan met een aantal afzonderlijke bedrijven, met toereikende andelen in de onverdeelde markegronden, die voldoende weide- en hooilanden en veengronden dienden te bevatten. De bedrijven moesten in de nabijheid van een riviertje liggen in verband met de noodzakelijke bevloeiing van het natuurlijke grasland (madeland) en in de omgeving van een grotere plaats met een verzorgende functie (marktcentrum, aankoop benodigdheden etc.). Bij elk bedrijf zou men ongeveer tien kolonistenwoningen kunnen plaatsen, terwijl men een opzichter met de bedrijfsleiding diende te belasten. Tenslotte achtte men de aanwezigheid of aanleg van een vaart zeer gewenst.

Inderdaad heeft de Maatschappij dit advies opgevolgd, althans wat het ankoopbeleid betreft. Ameshoff vermeldde zelf reeds ${ }^{6}$, dat de Maatschappij het "gehucht" Westerbeeksloot in de gemeente Vledder had gekocht van R.A.L. Nobel, lid van Provinciale Staten van Drenthe. In feite was Westerbeeksloot een landgoed, dat in de $\mathrm{I}$ 7e eeuw was gesticht door Jhr. François van Westerbeeck, commandant van de vesting Steenwijk, die destijds een aanvang maakte met de vervening van het Vledderveen en omgeving tot aan de Friese grens en het gebied van het dorp Nijensleek. Hiertoe sloot hij een serie overeenkomsten met de Vleddermarke en groef hij de Westerbeeksloot naar de Vledder Aa voor de turfafvoer vanuit dit gedeelte van zuidwest-Drenthe naar de marktplaats Steenwijk7. Aan de Westerbeeksloot verrees een landhuis met dezelfde naam.

Na de verkoop van het landgoed (onder de benaming "heerlijkheid") in 1727 aan Steven van Royen, koopman te Amsterdam, veranderde het opnieuw van eigenaar in 1760, toen de erven Van Royen de bezittingen, uitgezonderd het huis en erf, verkochten aan Jhr. N. van Heloma te Heerenveen. Deze kocht meer grond en aandelen in de Vleddermarke, waarna hij omstreeks I $77^{\circ}$ „uitscheiding” verkreeg uit de marke en zijn drie waardelen hem na opmeting werden toebedeeld in groenland en veengrond. Aldus nam het landgoed in omvang toe. Van Heloma bouwde terzelfder tijd een eigen huis, dat vermoedelijk het tegenwoordige huis Westerbeek is, en legde tevens de wegen aan naar Vledder, Wapserveen en Noordwolde8.

Bijna zestig jaren bleef het goed eigendom van de familie Van Heloma. 
In september I 8 I 7 verkochten Nicolaas en Marcus van Heloma, minderjarige kinderen van wijlen Marcus van Heloma en Aletha Catrina van Scheltinga, het landgoed bij publieke veiling ten overstaan van notaris S. J. van Royen te Vledder aan de eerdergenoemde Richard Andreas Ludolphie Nobel ${ }^{9}$. In de zomer van 18 I 8 verklaarde laatstgenoemde zich reeds bereid zijn bezittingen aan de Maatschappij te verkopen voor $f 56.000$, - . De koopakte werd eerst op 7 juli 18 I 9 notarieel gepasseerd.

De eerste aankoop van de Maatschappij bestond uit de volgende 14 percelen:

I. een herenhuis met enige tuingrond en bossen, verhuurd voor $f 4^{\circ},-$ (na aankoop verbouwd en in gebruik bij de directie);

2. een huisje en schuur met een kampje weiland, groot $\mathrm{I} / 3 \mathrm{mg}$, gelegen naast $\mathrm{I}$, verhuurd voor $f 20$, - (in gebruik bij de directie);

3. een boerenplaats groot 25 muddero bouw- en weiland, gelegen achter Moerhoven en genaamd De Hogemaat, met 6 dagmat ${ }^{I}$ hooiland te Eesveen ${ }^{12}$ (verhuurd voor $f 25^{\circ},-$ ). Het huis in gebruik bij de directie, voor de helft geschikt gemaakt tot huis voor de adjunct-directeur voor $f 625$, 一, het bouw- en weiland werden gebruikt voor de stichting van kolonie $\mathrm{I}$, de twee percelen hooiland in gebruik bij de Maatschappij;

4. een herberg met 400 roeden $^{13}$ land, gelegen voor de herberg, en de tuin erachter. Het land getrokken in kolonie I, de herberg verbouwd voor $f$ 4200, - en vermeerderd met een weidekamp (behoord hebbend tot 5). Hierna verhuurd aan A. Schuttelaar voor f 900, ;

5. een keuterij met $x_{4}^{1} \mathrm{mg}$ weiland en 3 mudden bouwland. Huis afgebroken. Weiland gevoegd bij 4, bouwland bij 6 ;

6. een boerenplaats met $2 \mathrm{mg}$ weiland, 6 dagmat hooiland te Eesveen, $\mathrm{I} \frac{\mathrm{I}}{2}$ mud bouwland in het z.g. Haverveld, groot omtrent $3 \mathrm{mg}$, benevens 2 mud bouwland genaamd Het Bultje (verhuurd voor $f$ roo,-). Het huis als magazijn in gebruik genomen, $2 \mathrm{mg}$ weiland en het bouwland getrokken bij kolonie I, het hooiland in gebruik bij de Maatschappij;

7. een keuterij groot 5 mudden land; getrokken bij kolonie II;

8. een boerenplaats groot 20 mudde bouw- en 4 mud weiland; de grond bij kolonie In, het huis verbouwd tot woning voor de adjunctdirecteur voor $f 200$, ;

9. een keuterij groot 3 mudde bouw- en 3 mudde weiland; het huis verbouwd tot onderdirecteurswoning, het land bij kolonie Iv; 
Io. een huisje en tuin; in gebruik bij de boekhouder van de koloniën I en II, verbouwd voor $f$ r 60 , - ;

i1. $35 \mathrm{mg}$ groenland genaamd Het Broek; bij kolonie I;

12. een stuk land genaamd De Kamp, groot $2 \mathrm{mg} 400$ roeden; bij kolonie I;

13. $62 \mathrm{mg}$ bosgrond; hiervan $\pm 16 \mathrm{mg}$ bij kolonie II, het overige in gebruik bij de Maatschappij;

I4. $490 \mathrm{mg}$ en 90 roeden heidegrond, waaronder begrepen het Hollandsche Veen en de Westvierdeparten ${ }^{14}$; hiervan getrokken $\pm 5^{\circ}$ mg bij kolonie I, $97 \mathrm{mg}$ bij kolonie II, $259 \mathrm{mg}$ bij kolonie Iv; het overige alsnog aan de Maatschappij.

Uit de voorgaande opsomming blijkt, dat men door de eerste ankoop tegelijkertijd in verscheidene behoeften voorzag. De drie boerenplaatsen en de drie keuterboerderijtjes omvatten een oppervlakte cultuurgrond, die met enig los land voldoende ruimte bood voor de eerste kolonistengezinnen. Het hooiland verschafte een deel van het benodigde veevoeder. Voor de verdere kolonisatie kon men gebruik maken van de heidegrond, die men verdeelde over 3 koloniën (I en II vormden later de kolonie Frederiksoord, Iv noemde men Wilhelminaoord). Tenslotte leverde de aankoop de nodige gebouwen op voor de directie, alsmede een logement voor de te verwachten bezoekers. De gehele oppervlakte is door Westendorp Boerma gesteld op ongeveer $800 \mathrm{mg}$, waarvan $700 \mathrm{mg}$ heide ${ }^{\mathrm{s}}$. Volgens het register van de akten van koop etc. bedroeg de totale oppervlakte echter ongeveer $625 \mathrm{mg}(=532 \mathrm{ha})$, waaronder $490 \mathrm{mg}(=417$ ha) heide, $62 \mathrm{mg}$ (= 53 ha) bos, 65 mudden en ro $\mathrm{mg} \mathrm{(=25} \mathrm{ha)} \mathrm{bouw-}$ en weiland en 12 dagmat en $35 \mathrm{mg}$ ( = 37 ha) hooiland.

Het register vermeldt verder nog, dat Westerbeeksloot belast was met $22 \frac{1}{4}$ schepel rogge als Sint Maartenspacht aan de predikant en koster van Vledder ${ }^{16}$ en met het onderhoud van twee percelen dijk te Vledder, van de weg en het kerkpad van Frederiksoord naar Vledder en de wegen naar Noordwolde en Wapserveen, zo ver als de koloniën zich uitstrekten, en met het onderhoud van de brug over de Aa en het kerkhek te Vledder.

Het aantal aankopen bewoog zich de eerste jaren (I8I8-182I) in stijgende lijn. Over de periode $1819-1824$ sloot de Maatschappij in totaal 75 koop- en ruilovereenkomsten betreffende onroerend goed, d.i. gemiddeld I 2 à $\mathrm{I} 3$ contracten per jaar. In slechts 20 van deze aankopen waren boerenplaatsen met opstallen begrepen, 20 andere betroffen uitsluitend los land, waaronder bouw- en grasland, heide- en veenpercelen. 
De resterende 35 aankopen hadden betrekking op losse aandelen in onverdeelde marken (heide- en veengrond).

Zoals bijlage I globaal aangeeft, lagen de aangekochte boerderijen en losse landerijen hoofdzakelijk in de gemeenten Vledder (vooral in en bij het dorpje Doldersum), Diever (Wateren en omgeving), Steenwijkerwold (ten noorden van Steenwijk) en Weststellingwerf (omgeving Steggerda en Noordwolde).

Enkele aankopen, van bijzondere betekenis voor de ontwikkeling van de landbouwkoloniën, verdienen afzonderlijke vermelding.

Het register noemt onder no. 8 een aankoop van mevrouw A.C. van Scheltinga, weduwe Heloma, Mr. Nicolaas van Heloma en Marcus van Heloma, die plaatsvond in januari 1820 en de volgende percelen betrof: I. een stuk heideveld, een perceeltje bouwland, enig turfveen en ondergrond, gelegen tussen het Hollandscheveen, de gronden van de Maatschappij en de ongescheiden marke van Vledder;

2. een perceel hoogveen en zandgronden tussen het Hollandscheveen en de Vledder Veenakkers;

3. de z.g. Oostvierdeparten ${ }^{14}$, groot $5 \mathrm{I} .747$ roeden $(=73 \mathrm{ha})$. I en 2 waren samen groot $2 \mathrm{I} .6 \mathrm{JI}$ roeden $(=3 \mathrm{I} \mathrm{ha})$.

De prijs van $\mathrm{I}, 2$ en 3 bedroeg één stuiver per vierkante roede $=$ $f$ 4.1 70,90. Verschillende voorwaarden waren gesteld ten aanzien van de turfafvoer, terwijl de gronden overigens vrij van lasten waren. $Z_{i j}$ zijn geheel benut voor de aanleg van het oostelijke gedeelte van kolonie IV (Wilhelminaoord), behalve enige gronden gelegen om en bij de steenbakkerij, waarvoor dit deel van het veen grotendeels is gebruikt.

De stichting van kolonie III, een gedeelte van Willemsoord, kon een aanvang nemen na de totstandkoming van de aankoop, vermeld onder no I I :

2 I februari i 820 en 13 november I 820 gekocht van gecommitteerden van de erfgenamen van het kerspel Steenwijkerwold: enige gronden in het Steenwijkerwoldscheveld, aan weerszijden van de heerweg van Steenwijk op Friesland, ter breedte van 70 roeden, van de huizen van Hendrik Punter en Jan Potberg tot aan de Friese grens en voorts van genoemde weg oostwaarst voorbij De Ronde Blesse en De Halle tot aan het veld van De Eeze ter zelfde breedte, onder zekere conditiën bij het contract vermeld, makende het gemelde heideveld $\pm 350 \mathrm{mg}$ ( $298 \mathrm{ha}$ ). Prijs $f_{3500,-17}$. In gebruik voor kolonie III.

De aanleg van kolonie vi, tussen III en IV in, werd mogelijk gemaakt door het koopcontract no. I 2 :

27 februari en 8 juli i 820 gekocht van Hendrik Oelkenbos voor 
$f 5500$, - : een boerenerf genaamd De Halle onder Steenwijkerwold met bouw-, groen-, boslanden en heidegronden, groot $\pm 100 \mathrm{mg}$ ( $85 \mathrm{ha}$ ). Nog $f_{15}$, - - voor de mest. Bezwaard met $f 44,75$ aan de Kerk te Steenwijkerwold en $f \mathrm{I}$, - en $\mathrm{I} \frac{1}{3}$ schepel rogge aan de stad Steenwijk. Het huis afgebroken. Cultuurgrond en heide voor $84 \mathrm{mg}$ gebruikt voor kolonie vI, het overige voor kolonie IIr.

Het Instituut voor den Landbouw te Wateren (gemeente Diever) is tenslotte in $\times 823$ gesticht op een complex gronden, waarvan de Maatschappij de eerste aankoop reeds verrichtte in $1819^{18}$.

In I 823 en I 824 zijn nog enkele boerderijen gekocht te Appelscha en Weper bij Oosterwolde (gemeente Ooststellingwerf). Deze zijn echter nooit voor de kolonisatie gebruikt.

Door de verwerving in eigendom van boerderijen kon de Maatschappij aanvankelijk onvoldoende voorzien in de behoefte aan ontginbare woeste grond. Dit ondanks de omstandigheid, dat doorgaans tevens aandelen (meestal waardelen genoemd) in de onverdeelde marken tot de boerenplaatsen behoorden. Het overgrote deel van de heide in het kolonisatiegebied was onverdeelde gemeenschappelijke eigendom van de gewaarden (de markegenoten), terwijl het veelal niet mogelijk was een bepaalde oppervlakte heide van de marken aan te kopen. Alleen de z.g. erfgenamen van het kerspel Steenwijkerwold zijn hiertoe bereid geweest.

In de andere gevallen volgde de Maatschappij noodgedwongen een indirecte weg om heideveld te verkrijgen. Men kocht in korte tijd zo veel mogelijk aandelen op, totdat men voldoende rechten in de marken had verworven. Herhaaldelijk is het voorgekomen, dat men een boerderij met aandeel in de marke kocht om deze later weer te verkopen en slechts het aandeel in de marke in eigendom te behouden. Tenslotte stelde men dan aan de volmachten van de marke voor te worden "uitgescheiden”, waardoor men een bepaald stuk heide kreeg toegewezen uit de onverdeeldheid.

Het eerste dergelijke convenant is gesloten met de Marke van Vledder op 24 oktober $1820^{19}$. De Maatschappij kreeg in eigendom:

1. $65 \mathrm{mg}$ heide in deze marke ( $55 \mathrm{ha})$;

2. een stuk heide geëvenredigd aan 44 koeweiden (= aandelen).

De Maatschappij deed afstand van de verschillende aan haar toebehorende koeweiden waardeel en betaalde bovendien $f 3000,-$. Alle grond is gebruikt voor kolonie II.

De volgende marke, die tot verdeling overging, was de Marke van Doldersum. De voorlopige punten van overeenkomst tussen de Permanente Commissie en de geërfden in de Marke van Doldersum, vast- 
gesteld op 6 juli i 821 , vermelden, dat aan de Maatschappij werd afge$\operatorname{staan}^{20}$ :

I. "een stuk grond langs de Friesche Scheiding, van de Vledder Scheiding af gerekend tot aan Wateren, in evenredigheid van de waardelen, die de Maatschappij in Doldersum bezat;

2. voor het aandeel der venen aan de noordwestzijde, die de Maatschappij wilde verwerven, werd deze schadeloos gesteld door andere venen, meer oostelijk gelegen, zullende de gemene venen of Bovenveenen geheel eigendom blijven der geërfden, met dien verstande nogtans, dat aan de Maatschappij een weg van 20 roeden breed werd toegestaan van de Oostvierdeparten tot daar, waar haar gronden, in deze bedoeld, een aanvang nemen. Zullende de venen, welke de Maatschappij en geërfden hierdoor verkrijgen, worden getaxeerd en de waarde naar evenredigheid door die, welke 't meest verkrijgt, worden vergoed;

3. de ondergronden, waarop de venen zich thans bevinden;

4. de Brink zal ongescheiden blijven;

5. zowel aan de Maatschappij als aan de geërfden zal worden toegekend het recht van uitweg naar zijn gronden, en zullen de bestaande wegen, communicatiën en waterleidingen door beiden worden onderhouden, tot daaromtrent nader zal worden overeengekomen;

6. zullen bij scheiding aan de Maatschappij worden afgestaan de gronden gelegen langs de Markte van Vledder, in ene strekking van de gronden der Maatschappij tot aan de Aa, komende het overige gedeelte langs de Markt van Wateren aan de geërfden”.

De verkregen gronden zijn gebruikt voor de (niet voltooide) stichting van kolonie vII of Doldersum ${ }^{2 I}$. De beschreven scheiding betrof $5 \frac{1}{4}$ waardeel.

Twee jaar later, op 1 juli I 823 , sloot de Maatschappij een convenant met de markerechters van de ongescheiden Marke van Diever en Wateren ter verdeling van het heideveld. Elders is deze scheiding uitvoerig beschreven $^{22}$. Voor elk der bijna 27 waardelen ontving de Maatschappij $42 \mathrm{mg} 332$ roeden ( $=36 \mathrm{ha}$ ) heidegrond in het noordwestelijke gedeelte van de gemeente Diever, grenzend aan Vledder en Friesland. De totale oppervlakte bedroeg dus niet minder dan \pm 972 ha. Van deze heide is $100 \mathrm{mg}$ gebruikt voor de stichting van het Instituut voor den Landbouw te Wateren, bedoeld voor de opleiding van middelbare en lagere ambtenaren in dienst van de Maatschappij. In feite was het de eerste 
landbouwschool in de provincie Drenthe en één van de eerste landbouwscholen van Nederland 23 .

In 1823 en 1824 hadden de meeste aankopen van de Maatschappij nog verder naar het noordoosten plaats in de Friese gemeente Ooststellingwerf. Hierbij nam de verwerving van losse aandelen in de marken een relatief belangrijker plaats in ten opzichte van de ankoop van behuisd en los land dan in de voorafgaande jaren. Dit was met name het geval in de Marke van Appelscha, waar nog veel ongescheiden heideveld en veen lag. De aandelen werden hier aangeduid in aantallen zodesteden resp. veenslagen.

De scheidingsovereenkomst met de gerechtigden in de onverdeelde heidevelden van Appelscha, gelegen tussen Appelscha en de landscheiding van Friesland en Drenthe, op I I februari I 824 tot stand gekomen, werd eerst in 1830 geëffectueerd 24 . De Maatschappij behoorde blijkens het proces-verbaal van opmeting d.d. 22 juli 1830 in totaal $25 \mathrm{r} / 420$ gedeelte of 621 ha 65 roeden 28 ellen. Deze oppervlakte werd uitgemeten evenwijdig aan de Fries-Drentse grens ter breedte van I 379 ellen. Het aandeel van de gerechtigden lag aan de zijde van de Appelsche duinen.

De Maatschappij heeft haar eigendommen in Ooststellingwerf nooit voor kolonisatiedoeleinden gebruikt. In 1832 en i 836 zijn enige percelen veengrond voor boekweitverbouw verhuurd voor I 2 jaar. Rekening houdend met de aankoop van gronden in de aangrenzende Drentse gemeente Norg onder Veenhuizen kan men uit de ontwikkeling van het grondbezit van de Maatschappij concluderen, dat de oorspronkelijke plannen tot aankoop van de heide- en veengronden tussen Steenwijk en Groningen grotendeels zijn verwezenlijkt, hoewel het kolonisatieproject slechts ten dele is gerealiseerd.

De laatste gronden, die men in eigendom verkreeg tussen 1829 en $184^{\circ}$ in de gemeente Vledder (bijlage $\mathrm{I}$ ), waren veenakkers in de Vledderveenen, die zijn gebruikt voor de turfgraverij ${ }^{25}$. De eerdergenoemde hooilanden onder Nijensleek en Eesveen zijn in 1840 door middel van een veiling verkocht. De totale oppervlakte bedroeg bijna 14 ha. Tenslotte is nog vermeldenswaard, dat op 20 november 1857 de algehele scheiding van het Dieverveld plaatshad. De Maatschappij bezat toen nog 2 aandelen, die ruim $8 \mathrm{r}$ ha opleverden ter waarde van $f^{\prime} 1728,-26$.

Het voorgaande overziende, kan men zich afvragen, of de eigendommen van de Maatschappij in de jaren 1819 -1 824, toen zij snel in omvang toenamen, de behoefte aan grond voor kolonisatiedoeleinden weerspiegelden 
of deze mogelijk overtroffen. Uit de ontwikkeling van de koloniën blijkt duidelijk, dat dit laatste inderdaad het geval was. Eilerts de Haan haalde het rapport van Van den Bosch van 24 september I 827 aan ${ }^{27}$, dat een totaal bezit (incl. de Ommerschans en Veenhuizen) vermeldde van 7000 ha, waarvan slechts 2700 ha was ontgonnen. De woeste grond vertegenwoordigde volgens Eilerts de Haan een investering van rond $f 200.000$,( $\pm f 5^{\circ}$, - per ha), die jaarlijks $f_{1} 0.000$, aan rente kostte zonder iets hoegenaamd op te leveren. In I 823 was kolonie vr, later administratief bij kolonie IIr (Willemsoord) gevoegd, geheel bevolkt, en bleek kolonie vII, naderhand Boschoord genoemd, slechts gedeeltelijk van bewoners te kunnen worden voorzien ${ }^{28}$. Niettemin ging men in 1824 op grote schaal voort met het doen van aankopen van grond en losse aandelen, vooral in Ooststellingwerf. Bij een voorzichtiger aankoopbeleid zou men zich wel hebben bedacht, daar enerzijds de opzending van kolonisten in tempo afnam, terwijl anderzijds nog uitgestrekte heidevelden voorradig waren bij Doldersum en Wateren.

Over de verhouding tussen cultuurgrond en woeste grond omstreeks I $83^{\circ}$ geeft tabel 2 enige bijzonderheden in de vorm van een samenvatting van de gegevens in bijlage 2 . Het basismateriaal voor deze overzichten is aanwezig in de stukken betreffende de classificatie der eigendommen van het kadaster ${ }^{29}$.

Tabel 2 - CULTUURGROND EN WOESTE GROND OMSTREEKS I830

\begin{tabular}{|c|c|c|c|c|c|c|c|}
\hline \multirow{3}{*}{ Gemeente } & \multirow{3}{*}{ Jaar } & \multicolumn{5}{|c|}{ Oppervlakte (ha) } & \multirow{3}{*}{$\begin{array}{l}\text { alle } \\
\text { grond }\end{array}$} \\
\hline & & \multirow{2}{*}{$\begin{array}{l}\text { cultuur- } \\
\text { grond I }\end{array}$} & \multirow[b]{2}{*}{ bos } & \multicolumn{3}{|c|}{ woeste grond } & \\
\hline & & & & heide & veen & zandverst. & \\
\hline Diever & 1826 & I 34 & - & 936 & - & - & 1070 \\
\hline Smilde & 1833 & 5 & 3 & $2 \mathrm{I}$ & - & - & 29 \\
\hline Vledder & 1825 & $5^{23}$ & 39 & 809 & 27 & 25 & 1423 \\
\hline Steenwijkerwold & $183^{\circ}$ & 436 & - & $4 \mathrm{I}$ & - & - & 477 \\
\hline Ooststellingwerf & r833 & 16 & - & 742 & - & - & $75^{8}$ \\
\hline Weststellingwerf & I 833 & 272 & 7 & 68 & - & - & 347 \\
\hline Vrije koloniën & $1825 / 33$ & $\times 3^{86}$ & 49 & 2617 & 27 & 25 & 4104 \\
\hline
\end{tabular}

I Bouw-, wei- en hooiland en tuingrond.

2 Ongebouwde eigendommen.

Bron: zie noot 29.

In het gebied van de vrije koloniën met hun naaste omgeving (nl. de gemeenten Diever, Smilde en Ooststellingwerf) bezat de Maatschappij ongeveer 4100 ha ongebouwde eigendommen, waarvan slechts rond 
I 400 ha in cultuur was of ruim een derde gedeelte. De cultuurgrond lag omstreeks $r 830$ overwegend in de gemeenten Vledder, Steenwijkerwold en Weststellingwerf, de woeste grond in Diever, Vledder en Ooststellingwerf. Dat de kolonisatie in 1825 een ontijdig einde had genomen, blijkt uit de volgende aantekening op de stukken van het kadaster bij de sectie Doldersum (kolonie vII): "2 I hoeven grotendeels ontgonnen tot bouwland, 25 uitgezet, maar als heide blijven liggen."

Volgens de toenmalige directeur Van Konijnenburg 30 bestond de grondeigendom van de Maatschappij in het gebied van de vrije koloniën en omgeving in 1859 uit I 100 ha cultuurgrond en 380 ha heide, veen en bos in de eigenlijke koloniën, alsmede \pm 40 ha cultuurgrond en ruim 2000 ha heide, veen en zandverstuiving in de omgeving van de koloniën onder de gemeenten Vledder, Diever en Ooststellingwerf (Appelscha). Tot de genoemde 40 ha behoorden twee verpachte boerderijtjes en enig verpacht los land, terwijl de heide in gebruik was als weide voor de schapen van de Maatschappij en die van andere eigenaren.

\section{BODEMGESTELDHEID EN ONTGINNING}

In het voorgaande is gebleken, dat de door de Maatschappij van Weldadigheid aangekochte gronden waren gelegen in de zuidwestelijke hoek van de provincie Drenthe en het aangrenzende gebied van Overijssel en Friesland, dus ten westen van het centrale Drentse zandplateau, het hoogste gedeelte van deze provincie. Het kolonisatiegebied maakt deel uit van het overgangsgebied langs de Drents-Friese grens met een uitloper in de kop van Overijssel. Dit overgangsgebied kenmerkt zich door een afwisseling van beekdalen en hoger gelegen zandruggen, welk patroon zich voortzet in de Friese Wouden.

De bodemgesteldheid van de bezittingen der Maatschappij werd dan ook grotendeels bepaald door de brede, van zuidwest naar noordoost verlopende rug, bestaande uit dekzand met een keileemlaag in de ondergrond, die plaatselijk dicht aan de oppervlakte komt. Dit is bv. het geval op het hoogste gedeelte van de zandrug te Willemsoord. Waar in deze rug lagere plekken voorkwamen met een stagnerende waterafvoer, trad vorming van hoogveen op, zoals in Vledderveen en langs de DrentsFriese grens bij Appelscha. Overigens was de rug bedekt met hoge heidegrond, die plaatselijk tot verstuiving was overgegaan, vooral tussen Doldersum en Wateren. Tenslotte lag in het beekdal van de Vledder Aa het oude grasland op zandig moerasveen.

Het overgrote deel van de gekochte gronden was woest. De woeste grond 
drukte destijds sterk zijn stempel op het landschap in deze streken, zoals blijkt uit het percentage woeste grond in de gehele gemeente Vledder, dat omstreeks I 800 nog \pm 85 bedroeg ${ }^{31}$ tegen 62 in $1845^{32}, 46$ in $1900^{33}$ en slechts 8 in $1954^{34}$. Van het landgoed Westerbeeksloot was in 1818 niet minder dan $7 / 8$ gedeelte woeste grond ${ }^{35}$.

Om de landbouwkoloniën te kunnen stichten moest Van den Bosch derhalve op grote schaal woeste grond laten ontginnen tot cultuurgrond in een tijd, waarin kunstmest volledig onbekend was. Hij ontveinsde zich niet, dat dit één van de grootste moeilijkheden zou zijn bij de tenuitvoerlegging van zijn plannen ${ }^{36}$.

Volgens de oorspronkelijke gedachten van Van den Bosch ${ }^{37}$ zou de heide worden verkaveld in kleine hoeven van $2 \mathrm{mg}(\mathrm{r}, \mathrm{l}$ ha) cultuurgrond, te verdelen in vier percelen van $\frac{\mathrm{r}}{2} \mathrm{mg}$. Indien de kolonisten in de zomer zouden arriveren, diende elke hoeve in twee jaren geheel te zijn ontgonnen. In het eerste jaar zou perceel I voor de helft plaggen verschaffen voor huisbrand en mestbereiding, de andere helft zou na verbranding van de heideplaggen (asbemesting) op de ongespitte grond worden ingezaaid met rogge of gerst met brem als ondergewas ${ }^{38}$. Perceel 2 zou men gezamenlijk ontginnen door de eventuele oerlagen door te spitten en de goede zwarte grond boven te houden. $\mathrm{Na}$ bemesting door plaggenverbranding en opbrengen van $\mathrm{I}_{3}-\mathrm{I}_{4}$ voer mest uit de mestput kon men in het voorjaar aardappels poten. Op dezelfde wijze zouden de percelen 3 en 4 in het tweede jaar worden ontgonnen.

De werkelijke gang van zaken is in de eerste jaren wel enigszins anders geweest. Westendorp Boerma gewaagt van "gehuurde arbeiders, die bij honderden tegelijk aan het werk waren" bij de eerste ontginning ${ }^{39}$. Van paarden werd volgens hem een ruim gebruik gemaakt om de grond te ploegen. Von Grouner vermeldt in zijn reisbeschrijving ${ }^{40}$, dat het eerste perceel van elke hoeve ter grootte van $85^{\circ}$ Hollandse roeden aanvankelijk in akkoordloon (mogelijk door vreemde arbeidskrachten) werd ontgonnen.

Aan deze uitvoerige verhandeling over de koloniën, waaraan Von Grouner in zijn reisverslag een afzonderlijk hoofdstuk heeft gewijd, is over de eerste aanleg nog het volgende ontleend.

Nadat een weg was gemaakt en sloten waren gegraven, ging men de grond verdelen in rechthoekige stukken van $3 \frac{1}{2} \mathrm{mg} \mathrm{(3} \mathrm{ha),} \mathrm{waarvan} \mathrm{de}$ breedte langs de weg eerst op 30 roeden was bepaald (diepte 70 roeden), maar later op 40-45 roeden werd gesteld (bij een geringere diepte). Met de grotere onderlinge afstand tussen de huizen meende men de zedelijkheid, moraal en huisvrede te bevorderen. Elke hoeve werd omringd door 
een ontwateringssloot, terwijl om elk drietal aangrenzende hoeven aan drie zijden een houtwal werd aangelegd ter breedte van $\mathrm{I} 2$ voet met een hoogte van 3-4 voet. Deze wal diende als windscherm en leverde tevens brand- en werkhout op. Waar nodig werd het land begreppeld. Vervolgens bouwde men de huizen.

Hierna nam de eigenlijke ontginning een aanvang op het eerdergenoemde gedeelte van $85^{\circ}$ roeden, dit is $\pm 40 \%$ van de gehele oppervlakte van elke hoeve. De plaggen werden met de spade verwijderd, op langwerpige hopen gezet, gedroogd en verbrand. Het branden achtte men strikt noodzakelijk om door de asbemesting binnen drie jaren een goede oogst te verkrijgen. $\mathrm{Na}$ verdeling van de as over de grond bracht men op arme grond nog 400 voer van 10 centenaar ${ }^{4}$ natte turf, die werd uitgespreid en aan weer en wind en de vorst werd blootgesteld. De turf viel hierdoor uiteen, waarna het geheel werd geëgd. De grond werd dan ten hoogste 6-8 duim diep geploegd en vervolgens met de hak tot een diepte van 16I 8 duim door en door losgemaakt, waarbij de bovenlaag bleef liggen.

Indien een vrij dikke veenlaag aanwezig was, bracht men deze naar boven om met zand te vermengen. Maakte de bodemgesteldheid dit wenselijk, dan bemestte men nog met een soort compost, bestaande uit paarden- en schapenmest en heideplaggen.

Von Grouner vermeldt in dit verband het volgende voorval. Van den Bosch meende aanvankelijk, dat de grond door een overmaat van stalmest zonder branden eerder vruchtbaar zou zijn dan zonder mest met branden van de plaggen. Een oude boer uit de omgeving waarschuwde hem echter, dat branden noodzakelijk was. Men ging een weddenschap aan en beiden ontgonnen een gelijk stuk heideveld. De boer brandde de grond en kreeg in het eerste en de volgende jaren goede oogsten. Van den Bosch brandde niet, maar bemestte overvloedig en spaarde geen arbeid; toch had hij pas in het derde jaar een goede oogst en verloor hij zijn weddenschap.

De overige grond van de hoeve (I $25^{\circ}$ roeden) moest de kolonist zelf ontginnen tegen dagloon. In het eerste jaar betaalde de Maatschappij hiervoor $f$ roo,- in het tweede jaar $f 91,-$. Het kwam echter wel voor, dat de Maatschappij ook deze grond in cultuur bracht en met boekweit beteelde (zonder mest) om voer en strooisel te verkrijgen voor haar paarden 42 .

In de verhandeling, die Van den Bosch in 1820 schreef 43, kan men nog enkele nadere bijzonderheden over de ontginningsmethoden aantreffen. Bij de heideontginning (zand, waarop niet meer dan 3-6 duim veen voorkwam) maakte men de plaggen $\pm I^{\frac{1}{2}}$ duim dik en zette deze op hopen. 
Zij werden voor driekwart langzaam verbrand met zo min mogelijk vlammen, waartoe men geleidelijk plaggen toevoegde. Dit verbranden gebeurde tegen de zaaitijd. De plaggen werden dan fijngeslagen en de nog warme as over de grond gestrooid, die tevoren was gespit (Van den Bosch sprak niet van ploegen). Het niet verbrande vierde deel van de plaggen diende voor de mest- of compostbereiding op de volgende wijze. De plaggen werden vermengd met I 5 vrachten verse paardenmest, I 5 vrachten straatvuil en 20 schepels 44 ongebluste kalk per vierde deel van de plaggen van I mg heide. De toevoeging geschiedde in lagen. $\mathrm{Na}$ twee maanden zette men de hoop om en na drie maanden was een homogene massa verkregen, die doorging voor een bijzonder goede meststof. De mest werd in de zomer bereid en in de herfst op het land gebracht, waarop men in het voorjaar zomerrogge zaaide.

De veengrondontginning gebeurde als volgt45. Indien de veenlaag 2-3 voet dik was, werd de bovenlaag tot I voet diep afgestoken, opgestapeld en verbrand. De rest van het veen werd doorgespit en op vaste afstanden doorsneden door sloten, die voldoende diep werden gegraven om 5-6 duim zand op het land te kunnen brengen. Het zand werd goed gemengd met het veen en de as, waarna men bemestte met het bovenomschreven mengsel met ongebluste kalk. Volgens Van den Bosch verkreeg men aldus een goed vochthoudende, vruchtbare cultuurgrond, die in het algemeen zeer produktief was.

Indien meer dan 3 voet veen aanwezig was, werd het tot turf gestoken, die men gebruikte in de steenbakkerij en de woningen.

In de Algemeene Verslagen wegens den Staat der Maatschappij van Weldadigheid en der Koloniën, in de eerste jaren opgesteld door Joh. van den Bosch, bracht de Permanente Commissie rapport uit aan de Commissie van Weldadigheid. Aan de hand van de opbrengsten der gewassen gaf Van den Bosch in de verslagen over I822/23 en I823/24 een beoordeling van de afzonderlijke koloniën. In kolonie I (Frederiksoord) was alle grond tegelijkertijd in cultuur gebracht, dit in tegenstelling tot de andere koloniën. De grondkwaliteit van kolonie II waardeerde hij als vrij matig. Kolonie in (Willemsoord) viel tegen door een minder gunstige toestand. De grond scheen een „antivegetaal principe” te bevatten, dat alleen was te bestrijden door herhaalde grondbewerking en bemesting. Kalk noch mergel bracht in het eerste jaar verbetering; na drie jaren constateerde Van den Bosch evenwel een grote mate van vruchtbaarheid. Kolonie IV (Wilhelminaoord) met veenachtige grond voldeed vrij goed en evenaarde II en op sommige plaatsen kolonie I in opbrengsten. 
Kolonie vr (het noordoostelijke gedeelte van Willemsoord) was grotendeels gelegen op zeer slechte grond.

In dit verband zijn de opmerkingen van betekenis die de bekende hoogleraar in de landhuishoudkunde Jan Kops heeft gemaakt in het landbouwgedeelte van het verslag over de staat der koloniën door een subcommissie uit de Commissie van Toezicht in $1823^{46}$. In augustus 1823 bezocht Kops gedurende drie dagen de vrije koloniën, waar hij werd rondgeleid door Van den Bosch en de directeur. Hij had de koloniën toen nog niet eerder gezien. De woeste grond achtte Kops voor het grootste deel beter dan de meeste andere woeste velden door een vlakke ligging, weinig of geen zandverstuivingen, een losse veenlaag en voldoende zand om mee te vermengen. Tevens bevond hij de grond voldoende vochthoudend. De ontdekking van mergel in kolonie III door de heer Matthiese uit Holstein in 1822 en later op vijf andere plaatsen, op een diepte van 8-10 en meer voet, noemde Kops voortreffelijk. De mergel was beter en goedkoper dan de ingevoerde schelpen, die tot kalk werden gebrand. De hoeveelheid achtte men voldoende om alle cultuurgrond te bemergelen. In I 823 was meer dan 15.000 voer verbruikt, waarvan men een gunstige uitwerking verwachtte 47 . Ook Kops vond kolonie III minder goed. De grond was niet veenhoudend en bestond hoofdzakelijk uit leem. $\mathrm{Na}$ enige jaren goede bewerking en bemesting meende echter ook Jan Kops, dat deze grond vruchtbaar bouwland zou worden na "vele vruchtbare stoffen uit de dampkringslucht te hebben aangenomen".

In de kringen van de Maatschappij beschouwde men de toegepaste ontginningsmethode destijds als nieuw. Ook de keuterboeren in de omgeving plagden wel eens een stuk heideveld af, maar deze zaaiden dan terstond boekweit in de as zonder een diepe grondbewerking en vermenging van veen met zand ${ }^{48}$. Waarschijnlijk was dit evenwel een onjuiste vergelijking, daar met de beschreven activiteit van de keuters blijkbaar is gedoeld op de veenbrandcultuur van boekweit, die destijds veel werd toegepast. Men mag deze cultuur echter niet op één lijn stellen met ontginning.

Latere schrijvers verschillen sterk van mening bij de beoordeling van de vroegere ontginningen door de Maatschappij. Zo stelt Westendorp Boerma in $1927^{49}$ : „De ontginning, door Van den Bosch persoonlijk geleid, werd ten uitvoer gelegd volgens methoden, waarop ook thans nog niet veel aan te merken valt. Daarbij werden voortdurend proeven genomen met nieuwe vondsten, waarover de omwonende landbouwers het hoofd schudden, maar die zij bij goed succes vaak navolgden".

Van Konijnenburg echter, die van I 829-1 859 directeur is geweest, 
schreef in een brochures0 ten tijde van zijn vertrek uit de dienst van de Maatschappij, dat een van de oorzaken van de financiële mislukking van de kolonisatie werd gevormd door de gebrekkige ontginning. De afgegraven veengrond was naar zijn mening onvoldoende bezand. Overigens vermeldde hij ook, dat de ontginning door de Maatschappij andere ontginningen in de omgeving had uitgelokt.

In zijn eerder aangehaalde werk ${ }^{51}$ stelde Eilerts de Haan, dat men te weinig praktische kennis had van de heidegronden. Hij vervolgde: „Toen de landbouwers in den omtrek der koloniën in 1818 den arbeid der Maatschappij aanschouwden, en van de gemaakte berekeningen hoorden, glimlachten zij, want zij wisten, beter dan de mannen der theorie, wat heidegrond is. Toch hebben zij hun voordeel gedaan met de proeven, door de Maatschappij genomen. Zij leerden van haar eene zorgvuldiger bewerking van den grond, de bereiding en vermenging van mestspeciën enz. Ja, het geschiedde menigmaal, dat wanneer de Maatschappij eene proeve staakte, omdat ze haar ondoelmatig toescheen, de omwonende boeren haar voortzetten en er zich best bij bevonden."

De eerste directeur van de Maatschappij na de afscheiding van de gestichten, Jongkindt Coninck, schreef in $1865^{52}$, dat de zware zwarte humusrijke zandgrond, die het grootste deel van Frederiksoord vormde, in de ondergrond leem en oerlagen bevatte. De betrekkelijk kleine oppervlakte afgegraven hoogveen noemde hij zeer slecht ontgonnen. De achtergebleven bovenste veenlaag (de bonkaarde) was nauwelijks bezand, terwijl men niets aan egalisatie had gedaan.

De latere directeur Van der Have drukte zich voorzichtiger uit53: "Ook de wijze, waarop de ontginning der heide werd uitgevoerd, schijnt te wenschen te hebben overgelaten." De huidige directie is van mening, dat een gedeelte van de cultuurgrond behoefte heeft aan herontginning.

Vergelijkt men de hiervoor weergegeven ontginningswijze met de huidige opvattingen over de heideontginning ${ }^{54}$, dan kan men constateren, dat de algemene opzet van de toenmalige ontginningsmethode in grote lijnen wel overeenkomt met de tegenwoordige inzichten. Op belangrijke punten is men echter te kort geschoten. Zo bedroeg de doorspitdiepte 16-I 8 duim of $\pm 40-45 \mathrm{~cm}$. Voor de aanleg van bouwland is evenwel een grondbewerking tot $\pm 75 \mathrm{~cm}$ gewenst om harde lagen te breken, indien deze aanwezig zijn. Het valt dus niet te verwonderen, dat deze lagen plaatselijk niet werden doorgespit, zodat wateroverlast moest optreden. Voegt men hierbij de onvoldoende egalisatie en bezanding van het afge- 
graven hoogveen, dan is het duidelijk, dat de gevolgde werkwijze naar hedendaagse maatstaven wel enkele tekortkomingen vertoonde.

In financieel opzicht zijn de ontginningen van de Maatschappij bevorderd door de wet van 23 december I 823 , door de Staten-Generaal aangenomen op voordracht van de Koning, waarbij de Maatschappij voor I 5 jaren vrijstelling verkreeg van grondbelasting. Ook steunde het Provinciaal Bestuur van Drenthe de activiteiten te Frederiksoord op initiatief van de gouverneur Hofstede 5 .

Het Algemeen Verslag over $1826 / 27$ vermeldt, dat in de vrije koloniën en Wateren (excl. de verspreide hoeven te Smilde, Steggerda, Weper etc.) destijds $1 \times 49$ ha in cultuur waren, terwijl de oppervlakte heide onder Doldersum, Diever en Appelscha toen \pm i 500 ha bedroeg. $\mathrm{Om}$ in eigen onderhoud te kunnen voorzien diende de oppervlakte cultuurgrond te worden verdubbeld tot $\mathrm{i} \mathrm{mg}$ per ziel. Dit betekende dus $6 \mathrm{mg}(5, \mathrm{I}$ ha) per gezin van 6 personen, d.i. \pm het dubbele van de oppervlakte der gestichte hoeven. Van een zo sterke uitbreiding van de oppervlakte cultuurgrond is echter niets gekomen.

Slechts in een langzaam tempo ging de heideontginning in die jaren voort. In het Algemeen Verslag over $\mathrm{I}_{32}$ is voor de eerste maal sprake van bebossing van heidegrond. In dit jaar is ten noorden van het Sterrebosch te Frederiksoord een perceel heide van \pm 6 ha bezaaid met gewone grove den, die zeer goed opkwam.

Terzelfder tijd ontgon men een klein gedeelte van dit perceel heide tot bouwland. De ligging is door de toenmalige directeur Van Konijnenburg als volgt omschreven ${ }^{56}:$ in kolonie I (Frederiksoord), iste wijk, achter het zg. Sterrebosch, langs de weg van de eerste naar de tweede regel (= rij) kolonistenwoningen. Het bouwlandperceel was 2 II $2 \mathrm{el}^{2}$ ( $\pm 0,2 \mathrm{ha}$ ) groot en verdeeld in twee akkers, elk 8 el breed (!) en ${ }^{3} 2$ el lang. De heidezode was dun en schraal door het vroegere afplaggen. Onder de zode lag grijs zand met op $\frac{1}{2}$ el diepte leemachtig zand. Men moest veel kleine en grote keistenen verwijderen. Het doel van de ontginning was het verkrijgen van klaverland (rode of snijklaver) voor de ruwvoederwinning ten behoeve van de veestapel.

Van Konijnenburg beschreef de hier toegepaste methode uitvoerig en vulde deze aan met een gespecificeerde opgave van de kosten en opbrengsten. In de winter van $1831 / 32$ werden een grenssloot en greppels gegraven. De vrijkomende grond bracht men over de heide, waarna deze $\frac{1}{2}$ el diep werd gespit, de bovenste steek grond boven houdend. Vervolgens bemestte men met 30 kleine voeren mengmest, bestaande uit paardenmest, slootaarde, verrotte aardappelen en ander afval, hetgeen 
overeenkwam met 10.000 pond zuivere stalmest. Na ploegen en eggen werd nogmaals bemest met een dubbele hoeveelheid mengmest, vervolgens opnieuw ploegen en eggen. In het voorjaar werd 4 mud blanke Engelse aardappels gepoot met de pootstok, die in september 80 mud opleverden $(=378 \mathrm{mud} / \mathrm{ha}$ ). Het tweede gewas was rogge, waarin in mei rode klaver werd gezaaid. In augustus 1833 bedroeg de roggeoost 9,62 $\operatorname{mud}(=45,5 \mathrm{mud} / \mathrm{ha})$.

\begin{tabular}{lc} 
Het aardappelgewas leverde een tekort op van & $\begin{array}{l}f 42,69^{5} \\
\text { de rogge een batig salde van }\end{array}$ \\
& $-2,60$ \\
\hline terwijl het klaverzaad etc. kostte & $\begin{array}{l}f 40,09^{5} \\
-2,70\end{array}$ \\
\hline & $f_{42,79^{5}}$
\end{tabular}

Voor dit bedrag, overeenkomende met $f$ 202,50 per ha, stond de klaver in september 1833 dicht op het land, 5 palm hoog, en zonder enige mest na de rogge. In het volgend voorjaar zou er 6 voer gier op komen, in de herfst zou men het klaverland ploegen om vervolgens weer aardappelen te verbouwen. Uit de gehele beschrijving blijkt, dat Van Konijnenburg deze ontginning gunstig beoordeelde.

Uit het rapport van de subcommissie uit de Commissie van Toezicht, ingesteld tot onderzoek van de toestand der koloniën en gestichten in I 834, blijkt, dat in I 833 een oppervlakte van 20 ha was ontgonnen. In de vrije koloniën was toen 1028 ha in cultuur, verdeeld over 375 hoeven. In de tien jaren, die sedert I 825 waren verlopen, was slechts incidenteel enige heide ontgonnen. De ongunstige financiële omstandigheden gedoogden niet, dat de oppervlakte cultuurgrond aanmerkelijk werd vergroot.

Ook te Wateren verliep de ontginning in een langzaam tempo. Het hier in 1823 gestichte Instituut voor den Landbouw was gebouwd op het heideveld temidden van $100 \mathrm{mg}(85 \mathrm{ha})$ bijbehorende grond, die door rechte wegen in vier gelijke percelen was verdeeld 57 . Het Algemeen Verslag over 1828 geeft aan, dat in dat jaar $5 \mathrm{mg}$ was ontgonnen, waardoor te Wateren in totaal $65 \mathrm{mg}$ ( $55 \mathrm{ha}$ ) in cultuur was. In verband met mestgebrek door ziekte en sterfte onder het vee was het volgende jaar echter slechts 47,5 ha in gebruik als cultuurgrond. In $1832 / 33$ werd een ander perceel heidegrond bij Wateren ter grootte van 30-40 ha ontgonnen tot grasland, dat 's winters onder water werd gezet ${ }^{58}$. Dit gebied kreeg later de naam Oude Willemsveld of de Oude Willem. 
Reeds in 1828 is men te Wateren begonnen met heide-ontginning tot bos $^{59}$. In de volgende jaren werd deze voortgezet. Zo is volgens het Algemeen Verslag over I 834 een overigens onbruikbare hoogte ,aan de linkerzijde, dadelijk bij het inkomen van het hek" met het beste gevolg bepoot met ongeveer 20.000 jonge berken.

Westendorp Boerma vermeldt, dat de ontginning in 1836 met kracht is hervat ${ }^{60}$. Dit blijkt evenwel niet duidelijk uit de verdere ontwikkeling van de vrije koloniën. Wel had Van den Bosch plannen opgesteld om zijn schepping financieel onafhankelijk van regeringssteun te maken ${ }^{6}$, maar dit doel is door hem niet bereikt. Ook voor de gewone koloniën waren nieuwe bepalingen van kracht geworden „ter verdere voltooiing en uitbreiding der Koloniën ${ }^{762}$, doch in feite is slechts sprake geweest van enige afronding van de vroegere ontginningen. Zo was de grond van verscheidene bestaande hoeven slechts ten dele ontgonnen. Vandaar de opmerking in 1837 : „Ook in de gewone Koloniën gaat men voort met de voltooiing der ontginning op de bestaande hoeven, die in 1839 geheel zullen kunnen worden beteeld" 63 .

Als nieuwe ontginning is alleen melding gemaakt ${ }^{64}$ van een heideontginning te Willemsoord door de kolonisten zelf voor i I nieuwe hoeven met woningen in $184^{\circ}$. Verder werd in de gewone koloniën sinds de stichting regelmatig turf gegraven in het hoogveen nabij Doldersum en op 9 akkers in het Vledderveen. De Maatschappij bezat hierin 18 van de 59 akkers. Door aankoop van een geheel blok in het Vledderveen in 1840 zou men gedurende 20 jaar in de behoefte kunnen voorzien ${ }^{65}$. Op het afgegraven veen (de dalgrond) werden echter geen nieuwe boerderijen gebouwd.

In I 844 is nog sprake van een klein stuk nieuwe grond, dat $240 \mathrm{mud}$ aardappelen per ha opleverde66. Dit perceel was bemest met water uit de aardappelbroodbakkerij. Sinds jaren bakte men het brood uit een mengsel van aardappel- en roggemeel. Met het water uit de bakkerij doelde men waarschijnlijk op het afvalwater van de aardappelmeelbereiding.

In de omgeving van het Instituut voor den Landbouw te Wateren ging de bebossing van woeste grond voort. In 1837 is b.v. 7 ha heide en $\frac{1}{2}$ ha schraal gespit bouwland bezaaid met dennenzaad67. In het Algemeen Verslag over $184^{\circ}$ constateerde men dan ook, dat te Wateren de houtteelt doorgaans meer werd beoefend dan in de gewone koloniën. „Een groote hoek gronds" ten noorden van het gesticht is in 1840 bepoot met 6000 eiken duimstekken.

Het Algemeen Verslag over 1848 vangt aan met de beantwoording door 
de Permanente Commissie van een twaalftal punten, naar voren gebracht door Prof. H. C. van Hall, directeur van de Landhuishoudkundige School te Haren en hoogleraar in de landhuishoudkunde te Groningen, als gecommitteerde van de Commissie van Toezicht ter inspectie van de koloniën in r 848. Deze beantwoording was grotendeels een weerlegging van de door Van Hall gedane suggesties. Zijn eerste advies behelsde de uitbreiding van de ontginning door mestaankoop, vooral te Veenhuizen. De Permanente Commissie oordeelde evenwel, dat slechts een langzame ontginning mogelijk was door geldgebrek en onvoldoende geschikte arbeidskrachten.

In 1849 had alleen enige ontginning plaats te Wateren, waar $\frac{1}{2}$ ha heideveld ten zuidoosten van het gesticht werd diepgespit en met verschillende houtsoorten beplant, terwijl elders te Wateren $\frac{1}{2}$ ha heide werd bezaaid met grove den ${ }^{68}$.

Tenslotte vermeldt het Algemeen Verslag over 1855 , dat in dit jaar in kolonie II (Wilhelminaoord) zes nieuwe woningen waren gebouwd, naar men mag aannemen op nieuw ontgonnen grond, terwijl het Algemeen Verslag over $185^{8}$ aangeeft, dat in kolonie I 0,66 ha, in kolonie II 0, I I ha voor de eerste maal was beteeld.

Nog in 1857 is wederom het voorstel gedaan de ontginning op grote schaal te hervatten, $\mathrm{nl}$. in een brochure over de Maatschappij, die vrij scherpe kritiek paarde aan ideeën voor de toekomst ${ }^{69}$. Schrijver beval aan op het vele honderden ha grote Appelscheveld, dat een geheel woest eigendom der Maatschappij was, nog een bedelaarsgesticht te vestigen. Een soortgelijk voornemen heeft de Maatschappij aanvankelijk gehad ten aanzien van het Dieverveld, waar kolonie XI, een tweede bedelaarsgesticht, in de zomer van 1824 reeds zou worden bevolkt ${ }^{70}$. Voor dit laatste plan zijn destijds alleen enige voorbereidende werkzaamheden verricht. Evenmin is het latere voorstel aangaande het Appelscheveld gerealiseerd.

Uit het voorgaande blijkt, dat de periode van grote ontginningsactiviteit van de Maatschappij slechts een zestal jaren heeft geduurd, nl. van I 81 $8- \pm$ r 824. Ten tijde van de afscheiding van de gestichten van de vrije koloniën (in 1859 ) was dan ook bijna tweederde gedeelte van het grondbezit in de vrije koloniën (incl. Wateren en omgeving) als woeste grond voorhanden. Van de 4000 ha was niet meer dan ongeveer I 500 ha in cultuur $7 x$. 


\section{ENKELE ECONOMISCHE ASPECTEN VAN DE AGRARISCHE STRUCTUUR}

\section{WATERBEHEERSING}

$T^{\mathrm{EN}}$ aanzien van de periode 18 1 8-1859 kan men in het kader van de 1 waterbeheersing ten behoeve van de landbouw alleen spreken van maatregelen ter bevordering van de afwatering. In dit verband is de hoogteligging van de grond van veel belang.

Deze varieerde in het kolonisatiegebied van de vrije koloniën tamelijk sterk $^{\mathrm{x}}$. Willemsoord, op de noordhelling van de Woldberg, was het hoogste punt. De West- en Oostvierdeparten in Wilhelminaoord lagen lager, langs de Friese grens. De weg van Noordwolde naar Frederiksoord loopt vanaf Noordwolde geleidelijk op om zijn hoogste punt te bereiken ongeveer halverwege Wilhelminaoord en Frederiksoord. Vanaf dit punt helt het terrein weer af naar de Vledder Aa. Boschoord ligt tenslotte $\pm 2 \mathrm{~m}$ hoger dan Wilhelmina- en Frederiksoord.

Westendorp Boerma stelt, dat bij de ontginning de eerste zorg een goede afwatering gold ${ }^{2}$. Hierin was voorzien in het reglement voor de ontginning, opgesteld door Van den Bosch. Hij voegt hieraan toe, dat het punt van de afwatering naderhand wat verwaarloosd schijnt te zijn. In hoofdstuk II is reeds vermeld, dat elke hoeve werd omgeven door een ontwateringssloot, alvorens de eigenlijke ontginning een aanvang nam. Plaatselijk was het nodig het land te begreppelen, waarschijnlijk in verband met het voorkomen van ondoorlatende lagen in de ondergrond, die bij de ontginning niet altijd werden gebroken. Nog tegen het einde van de I 9 de eeuw had men bij grote regenval te kampen met wateroverlast door de dichte leembanken en door afstroming vanaf de hogere gronden, vooral des winters ${ }^{x}$. Men was toen dan ook van mening, dat op de oude cultuurgrond bij de ontginning geen voldoende afwateringssysteem was aangelegd. Anderzijds heeft men des zomers ongetwijfeld last gehad van verdrogingsverschijnselen, vooral in de eerste decennia wegens het geringe humusgehalte (behalve in Wilhelminaoord, waar de grond veenachtig was). Het slechte natuurlijke grasland langs de Vledder Aa kon 
worden bevloeid door middel van stuwen, die in het riviertje waren geplaatst ${ }^{3}$.

Het grondgebied van de vrije koloniën werd doorsneden door twee hoofdwegen en twee kanalen, die omstreeks i 820 door de Maatschappij zijn gegraven voor de scheepvaart. Het eerste kanaal is het verlengde van de oorspronkelijke Westerbeeksloot te Frederiksoord, ook wel Kolonievaart, Noordwoldigervaart of Splittinge genaamd, en loopt van de Vledder Aa via Frederiksoord en Wilhelminaoord naar Noordwolde. Loodrecht hierop staan de beide zijtakken langs de Friese grens, resp. door de Oostvierdeparten naar Boschoord en door de Westvierdeparten naar Willemsoord. Deze kanalen zijn in het terrein nog terug te vinden en vormden vanouds de hoofdafwateringen voor het grootste deel van de gronden; zij voeren het water af naar de Vledder Aa en voor een kleiner gedeelte naar de Linde in Friesland.

Von Grouner tekende reeds in $182 \mathrm{I} / 22 \mathrm{op}$, dat het verval in het kanaal te Frederiksoord 5-6 voet bedroeg. Ter wille van de scheepvaart had men twee houten sluizen gebouwd met optrekbare schuiven ${ }^{4}$. Bij de oever van de Vledder Aa was waterafvoer en -inlaat mogelijk door middel van een door de wind aangedreven, verplaatsbare Archimedische schroef ("Wasserschraube"). De Maatschappij had deze voor $f 300$,gekocht van de boeren in een naburig dorp5. Hoewel deze maatregelen in de eerste plaats werden getroffen voor de scheepvaart, zal waarschijnlijk tevens de waterbeheersing in de landbouw hiermede min of meer zijn gediend.

De schroefinstallatie voldeed blijkbaar op den duur onvoldoende. In I 855 sloot de Maatschappij nl. een overeenkomst met de „korenmolenaar" K. Spikman te Havelte, op verzoek van laatstgenoemde, waarbij deze vergunning kreeg tot het bouwen van een korenmolen op koloniale grond aan de uitmonding van de Kolonievaart in de Vledder Aa. Hij werd bovendien begunstigd met het malen van het graan voor de gewone koloniën en zou van de Maatschappij een jaarlijkse toelage van $f$ roo,- ontvangen voor het opmalen van water uit de Aa, indien men de vereiste toestemming van de betrokken autoriteiten zou verkrijgen. Het opmalen was nodig om de vaart 's zomers in bevaarbare staat te houden 6 .

Het Jaarverslag over I 856 vermeldt, dat deze molen op I januari 1856 in werking is gekomen en uitmuntend voldeed. In de loop van I 857 werd voor het eerst water opgemalen, hetgeen een gunstig effect scheen te zullen hebben. Het volgende Jaarverslag (over I 857 ) deelt echter mede, dat de molen te Frederiksoord naderhand geen water meer 
kon oppompen door de lage waterstand in de Aa. Als watermolen is ook deze molen waarschijnlijk geen groot succes geweest.

Bovenstrooms langs de Aa liet de afwatering veel te wensen over. De waterlopen, die de Aa vormden, en deze zelf, kronkelend langs de meer afgelegen gronden van de Maatschappij onder Appelscha en Groot Wateren, dienden afdoende te worden verbeterd. De andere aangelanden stelden hierin minder belang en wilden aanvankelijk niet medewerken. In de zomer van 1842 hoopte de Permanente Commissie de verbetering tot stand te kunnen brengen7. Inderdaad is de Oude Loop, een uitgestrekte waterleiding van het Appelscheveld naar de Aa beneden Wateren, in 1842 verbeterd, evenals enige andere waterlossingen ${ }^{8}$.

\section{BEDRIJFSGROOTTESTRUCTUUR}

In de oppervlakte cultuurgrond van de bedrijven in de gewone koloniën is in de periode $1818-1859$ weinig of niets veranderd.

Hiervoor is reeds gewezen op het oorspronkelijke plan van Van den Bosch de kolonistenhoeven slechts $2 \mathrm{mg}(=\mathrm{I}, 7 \mathrm{ha})$ groot te maken. Dit voornemen vloeide voort uit zijn inzichten ten aanzien van de oorzaken van de armoede, die hij uitvoerig heeft beschreven in zijn eerste Verhandeling9. Op zijn theoretische beschouwing baseerde hij de wenselijkheid de te stichten landbouwkoloniën op te bouwen uit een voldoende groot aantal kleine bedrijven. Op grote landbouwbedrijven waren niet alleen meer paarden dan op de kleinere, ook werd op de eerstgenoemde meer geploegd in plaats van gespit en was daar meer grasland en vee nodig voor de mestvoorziening. De kleine bedrijven hadden daarentegen de beschikking over relatief meer menselijke mest, terwijl men een betere grondbewerking kon toepassen. Per morgen bouwland nam Van den Bosch echter wel een gelijke graanoogst aan op grote en kleine bedrijven ${ }^{10}$.

Zelfs becijferde hij, dat een gezin van gemiddeld 2 volwassenen en 4 kinderen zou kunnen bestaan van de opbrengst van i $\mathrm{mg}$ bouwland voor aardappelverbouw met uitsluitend handenarbeid. Daar hij echter de mogelijkheid aanwezig achtte, dat de mestvoorziening door de gezinsleden („sekreetmest”) en 2 of 3 varkens tekort zou schieten, stelde hij vast, dat elk gezin nog over een tweede morgen grond diende te beschikken. Dan kon men afwisselend I mg bebouwen en I mg braak laten liggen. Bovendien wilde Van den Bosch per gezin I mg uittrekken voor een sparrenbos om een uitzet te kunnen verschaffen aan de oudere kinderen, wanneer die in de gewone maatschappij zouden terugkeren. 
Tenslotte moest elk gezin nog enige roeden tuingrond ter beschikking hebben. De kolonistenhoeven zouden dus ruim $3 \mathrm{mg}(=2,6 \mathrm{ha})$ groot zijn, waarvan $2 \mathrm{mg}$ cultuurgrond en $\mathrm{I}$ mg bos ${ }^{\mathrm{I}}$.

Bij de bepaling van de oppervlakte van de hoeven liet Van den Bosch zich niet alleen leiden door zijn inzichten in de oorzaken van de armoede, zoals hiervoor beschreven, maar evenzeer door de landbouwkundige toestand in het Land van Waas in de Zuidelijke Nederlanden, in die tijd niet veel minder dan een voorbeeldgebied voor andere landen. In het interessante, maar enigszins oppervlakkige eerste rapport van de Commissie van Toezicht over de toestand der koloniën d.d. I7 september I $819^{12}$, opgesteld door Van Hogendorp en Siderius, heet het, dat het succes van de kolonisatie werd gewaarborgd door de (korte) ervaring te Frederiksoord en de eeuwenlange ondervinding in het Land van Waas, waar 250 jaar tevoren een soortgelijk heideveld lag. De Hertog van Parma liet daar voor militaire doeleinden een kanaal graven, waarlangs geleidelijk en op natuurlijke wijze een welvarende landbouwstreek was ontstaan. Een bedrijfsgrootte van $2 \mathrm{mg}$, I $\mathrm{mg}$ en zelfs $\frac{1}{2} \mathrm{mg}$ was in het Land van Waas voldoende gebleken voor het bestaan van een gezin. Deze bestaansbasis werd mede verschaft door het teeltplan, waarin vlas en rapen een belangrijke plaats innamen. De vlasverwerking vormde eveneens een bron van verdienste. Te Frederiksoord zijn beide gewassen nooit van veel betekenis geweest. Het genoemde rapport geeft verder aan, dat de hoeven te Frederiksoord aanvankelijk iets meer dan $2 \frac{3}{4} \mathrm{mg}$ groot waren gemaakt, in $182 \mathrm{I}$ en later echter $3 \frac{\mathrm{I}}{2} \mathrm{mg}^{\mathrm{I}}$.

Uit de tweede verhandeling van Van den Bosch, geschreven in 1820 , blijkt duidelijk, dat het braaksysteem noch de bosbouw op de kolonistenhoeven is ingevoerd; het bouwplan was afgestemd op $3 \frac{1}{2} \mathrm{mg}$ cultuurgrond ( $=3 \mathrm{ha}$ ) per hoeve, waarvan $\mathrm{I} / 3 \mathrm{mg}$ tuingrond ${ }^{14}$. Het zou mogelijk zijn geweest per gezin meer grond te geven, aldus de stichter. Het eerste doel was echter een zo groot mogelijk aantal armen te bevoordelen. Ook moesten zij het niet al te goed hebben, daar anders verkwisting zou kunnen ontstaan. Tenslotte had men rekening te houden met de beschikbare werkkracht in overwegend lichamelijk en geestelijk niet sterke gezinnen, dikwijls het uitschot van de stadsbevolking, zo argumenteerde Van den Bosch.

Naarmate de aanleg van de koloniën vorderde, groeide het aantal hoeven aan tot 416 , waarvan er in oktober 1827 echter niet minder dan 94 onbewoond waren ${ }^{15}$. Per 3 I december 1827 was dit aantal gedaald tot $66^{16}$. Bovendien was van een klein gedeelte der hoeven niet alle grond ontgonnen. Reeds eerder is vermeld, dat omstreeks deze tijd het 
inzicht rijpte, dat per gezin van 6 personen $6 \mathrm{mg}$ cultuurgrond benodigd was, wilden de koloniën in eigen onderhoud kunnen voorzien'17. Van een vergroting van de hoeven is tot I 859 evenwel geen sprake geweest. Ook uit andere aanwijzingen mag men wel de conclusie trekken, dat de geringe bedrijfsoppervlakte per hoeve onvoldoende was om een volgroeid gezin in de gegeven omstandigheden een redelijk bestaan te verzekeren.

Uit de stukken betreffende de classificatie der eigendommen voor het kadaster is het overzicht van tabel 3 samengesteld, dat de situatie omstreeks $188_{3}$ o weergeeft per gemeente. Hieruit blijkt, dat de meeste kolonistenhoeven $2 \frac{1}{2}-3$ ha groot waren. De 54 oudste hoeven te Frederiksoord waren echter gemiddeld \pm 2 ha. In de omgeving van Steggerda lagen 5 hoeven van \pm 4 ha.

Tabel 3 - BEDRIJFSGROOTTESTRUCTUUR OMSTREEKS I $83^{\circ}$

\begin{tabular}{|c|c|c|c|c|}
\hline Gemeente & Jaar & Sectie & $\begin{array}{l}\text { Aantal } \\
\text { hoeven }\end{array}$ & $\begin{array}{l}\text { Oppervlakte cultuur- } \\
\text { grond (ha) per hoeve }\end{array}$ \\
\hline Diever & I 826 & Wateren & $\begin{array}{c}3 \\
\text { Instituut }\end{array}$ & $\begin{array}{r} \pm 20 \\
50\end{array}$ \\
\hline \multirow[t]{2}{*}{ Vledder } & 1825 & Frederiksoord & 75 & \pm 3 \\
\hline & & Doldersum & $\begin{array}{l}54 \\
21\end{array}$ & $\begin{array}{c} \pm 2 \\
\text { (grotendeels ontgonnen) }\end{array}$ \\
\hline \multirow[t]{2}{*}{ Steenwijkerwold } & 1830 & Willemsoord & 125 & 2,6 \\
\hline & & Vierde Wijk & $\mathrm{r} 6$ & \pm 3 \\
\hline \multirow[t]{3}{*}{ Weststellingwerf } & I 833 & Noordwolde & $3^{8}$ & 2,9 \\
\hline & & Kolonie & $3^{8}$ & 2,8 \\
\hline & & Steggerda & 5 & \pm 4 \\
\hline
\end{tabular}

Bron: zie noot 29 hfdst. $\mathrm{u}$.

De 3 hoeven te Wateren waren verpacht aan kolonisten; bovendien bezat de Maatschappij hier nog een hoeve van dezelfde grootte, die was verpacht aan een niet-kolonist. Aan het Instituut voor den Landbouw was feitelijk het enige bedrijf verbonden, dat de Maatschappij in het gebied van de vrije koloniën geheel in eigen exploitatie had. Te Doldersum waren nog 25 hoeven in het terrein uitgezet, maar in 1825 nog in het geheel niet ontgonnen.

Ook de in bijlage 2 genoemde boerenplaatsen te Smilde ( 8 ha cultuurgrond, waarvan 3 ha bos) en Weper in de gemeente Ooststellingwerf ( $16 \mathrm{ha}$ ) waren verpacht aan niet-kolonisten. Hetzelfde geldt voor een 
gedeelte van het losse hooi- en weiland. Het hooiland te Frederiksoord, Nijensleek en Eesveen was echter in eigen exploitatie.

In de hiervoor weergegeven bedrijfsgroottestructuur is in de periode tot I 859 vrijwel geen verandering gekomen. Alleen het landbouwbedrijf van het Instituut te Wateren is vergroot door ontginning en door samenvoeging met de vier verpachte hoeven tot een totale oppervlakte van omstreeks 175 ha sedert $\mathrm{I} 833$. In de oppervlakte van de gewone kolonistenhoeven kwam geen wijziging. Uit het vruchtwisselingsplan, dat in I 840 van kracht was ${ }^{18}$, blijkt, dat dit was afgestemd op 3 ha cultuurgrond per hoeve.

Een beoordeling van de bedrijfsgroottestructuur, die ongunstig uitviel, treft men aan in het rapport van de Staatscommissie, ingesteld op 26 oktober $184 \mathrm{I}$ in verband met de slechte financiële positie van de Maatschappij en de door het Rijk verstrekte subsidies. In het landbouwkundig gedeelte van het rapport, samengesteld door Worp van Peyma, een landhuishoudkundige uit Friesland, is ten aanzien van de 398 hoeven in de vrije koloniën sprake van het foutief geachte uitgangspunt van de Maatschappij: „het meeste produkt op de kleinste oppervlakte”. De commissie gaf de voorkeur aan de stelregel: "het meeste produkt per arbeidskracht" 19 . Voor die tijd wellicht een revolutionaire uitspraak!

Min of meer hetzelfde geluid klinkt door in het rapport van de subcommissie uit de Commissie van Toezicht, die de koloniën in augustus I 846 inspecteerde. Aan dit rapport mag men ongetwijfeld grote waarde hechten, daar het landbouwgedeelte is geschreven door de bekende landbouwkundige W.C. H. Staring20. Over de grootte van de hoeven handelt de volgende alinea uit genoemd rapport ${ }^{21}$, die tevens enig licht werpt op de oorspronkelijke gedachten betreffende de exploitatievorm en de feitelijke situatie dienaangaande in $\mathrm{I} 846$. Daarom is deze alinea hieronder volledig geciteerd.

„Het bezoek in deze Koloniën heeft ons tot eene gewigtige bedenking geleid, welke wij niet kunnen nalaten, $u$ mede te deelen, hoewel zij eigenlijk meer de oorspronkelijke inrigting, de grondslagen der kolonisatie aangaat, en alzoo minder tot de bevoegdheid der Commissie van Toevoorzigt kan worden geacht te behooren. De gewone Koloniën bestaan uit een aantal van omstreeks vier honderd woningen, elk met $2 \frac{1}{2}$ bunders bouwland en io Ned. roeden tuingrond, waarop volgens het oorspronkelijk plan, een huisgezin met twee melkbeesten een voldoend bestaan zou vinden. Aanvankelijk echter zou de Maatschappij voor hare rekening deze hoeven bewerkt hebben, met behulp der bewoners als daghuurders, totdat deze den landbouw genoegzaam hadden geleerd en langzamerhand 
allen in zoogenaamde vrijboeren of pachters van de Maatschappij waren veranderd. Als vrijboeren betaalden zij eene pacht van $f 45,-$, en genoten daarvoor het vrij gebruik hunner hoeven en eenige andere voordeelen, uit hunne betrekking met de Maatschappij voortspruitende. Maar eene ondervinding van bijna dertig jaren heeft aangetoond, dat het niet mogelijk is, om, in den regel, deze menschen aan zichzelven over te laten, zonder hen na weinig tijds tot volslagen armoede, en hunne hoeven tot den oorspronkelijken niets opbrengenden toestand teruggebragt te zien. Ruim een twintigtal vrijboeren bestaan er op dit oogenblik, maar verre de meesten zullen eerlang tot den staat van gewone kolonisten moeten terug keeren, hunne hoeven in eenen jammerlijken en hoogst uitgeputten toestand aan de Maatschappij teruggevende. Hetgeen dus de uitzondering moest zijn, het bebouwen namelijk der hoeven door de Maatschappij, is alzoo door den drang der omstandigheden, de regel zelf geworden, en men mag het oorspronkelijk plan van den stichter der koloniën ten dien opzigte als geheel mislukt beschouwen. - Maar is nu de indeeling in kleine hoeven, bij het vooruitzigt, dat men deze nimmer als pachthoeven zal kunnen uitgeven, geen groot bezwaar bij de bewerking der gronden door de Maatschappij? Wij gelooven dat dit niet ontkend kan worden, en dat een ieder ons zal moeten toestemmen, dat eene vereeniging van b.v. een tiental huisgezinnen in grootere gebouwen, omringd door 25 bunders bouwland, op eene vrij wat eenvoudiger en goedkooper wijze ware te administreren. En zou het nu niet af te keuren zijn, dat de Maatschappij evenwel voortgaat, met het aanleggen van dezelfde kleine hoeven, wier inrigting thans niet meer aan het oorspronkelijk doel blijkt te beantwoorden? - "

De suggestie, gedaan in de aangehaalde beschouwingen, die eigenlijk een bedrijfsvergroting beoogde, is door het toenmalige bestuur van de Maatschappij niet overgenomen. Eerst na 1859 zou een hervorming tot stand komen, die tot op zekere hoogte beantwoordde aan Staring's gedachtengang.

Volledigheidshalve verdient aan het einde van deze paragraaf vermelding, dat de vrije koloniën in I 859 in totaal 434 hoeven telden, die gemiddeld 2,7 ha groot waren volgens opgave van de toenmalige directeur $^{22}$. Het landbouwbedrijf van het Instituut voor den Landbouw te Wateren bestond toen uit 200 ha cultuurgrond en 285 ha andere gronden, hoofdzakelijk heide, die dienst deed als schapenweide. 
Bij de behandeling van de verkaveling van de vrije koloniën kan men twee uitgangspunten aannemen. Omdat de exploitatiewijze in de beschouwde periode feitelijk deze was, dat de cultuurgrond voor het overgrote deel in eigen exploitatie was bij de Maatschappij, zullen eerst enkele opmerkingen worden gemaakt over de ligging van het gehele complex cultuurgrond. Vervolgens zal het een en ander worden medegedeeld over de indeling van de kleine hoeven in percelen.

Zoals in hoofdstuk II is beschreven, volgde de aanleg der koloniën de reeks aankopen van woeste grond. Bij het aankoopbeleid was Van den Bosch in zoverre beperkt in zijn mogelijkheden, dat hij aanvankelijk geen aaneengesloten, uitgestrekt heideveld kon verwerven. Hij moest genoegen nemen met de min of meer toevallige ligging van hetgeen te verkrijgen was. Daar de gemeentegrenzen in veel gevallen, overeenkomstig de markegrenzen, de heidevelden rechtlijnig verdeelden, moest het kolonisatiegebied noodzakelijkerwijs wel een grensgebied zijn. In Frederiksoord was de situatie afwijkend; de heide lag hier binnen de gemeente Vledder tussen het dorp van die naam en de in de richting van Steenwijk gelegen, in de late Middeleeuwen ontstane nederzetting Nijensleek. Toch kan men wel constateren, dat de ruimtelijke ligging van het "landbouwbedrijf” van de Maatschappij in de vrije koloniën een "grensgeval" was met een eigenaardige en voor het beheer ondoelmatige T-vorm. Men kan zich de horizontaal van de $T$ voorstellen langs de Overijsselse kant van de Overijssels-Friese grens en aan weerszijden van de Drents-Friese grens. De verticaal vormt dan de wig, die de gemeente Vledder doorsnijdt. Figuur I brengt de situering van de koloniën in beeld.

Alleen aan de zuidelijke einden van de horizontaal en de verticaal van de $T$ kan men spreken van enige kernvorming (resp. Willemsoord en Frederiksoord). Overigens waren de koloniën een typische ontginningsnederzetting met verspreide bebouwing. De grootste lengte was 3 uren gaans, de breedte hier en daar 3 kwartier ${ }^{22}$. Ten behoeve van het bestuur, het toezicht op en de leiding van de werkzaamheden waren de koloniën dan ook verdeeld in enkele wijken. Onder de directeur, die gevestigd was te Frederiksoord en ook de algemene leiding had over de gestichten te Ommerschans en Veenhuizen, stond een adjunct-directeur voor de vrije koloniën, eveneens woonachtig te Frederiksoord. Aan het hoofd van elke kolonie was een onderdirecteur gesteld; de leiding van elke wijk, bestaande uit 24 woningen, was toevertrouwd aan een wijkmeester. Onder 


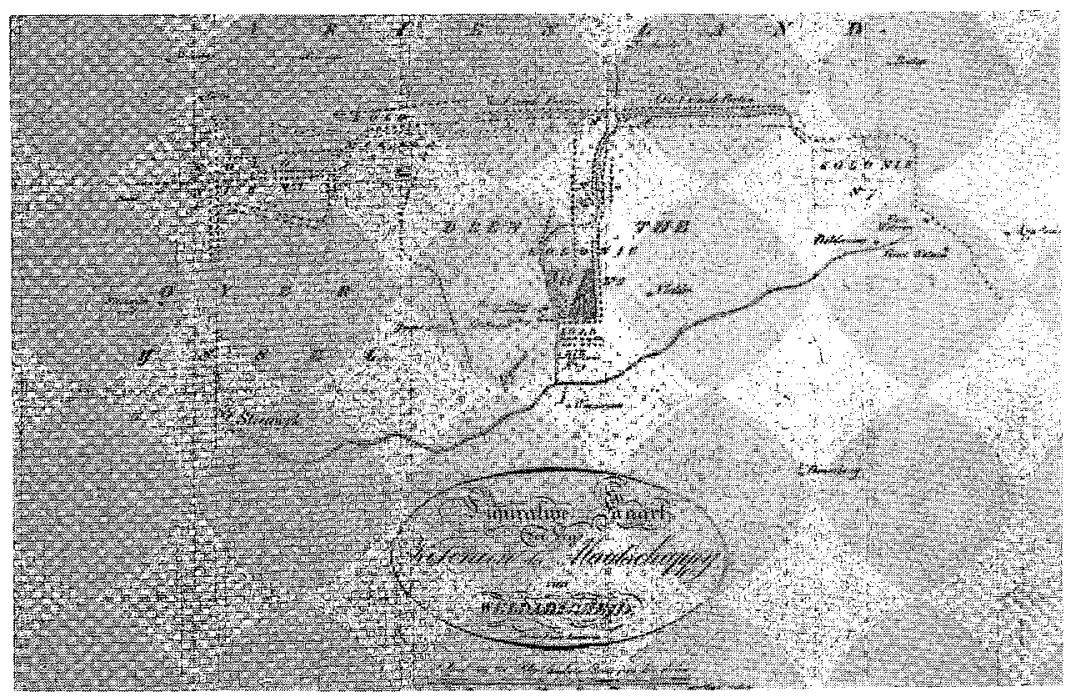

FIG. I - Plattegrond van de vrije koloniën. Ontleend aan het tijdschrift De Star, (v) $1823, \mathrm{blz}, 423$.

FIG. 2 - Gezicht op een vrije kolonie. Overgenomen uit Westendorp Boerma, Johannes van den Bosch, t.a.p., blz. I 35 .

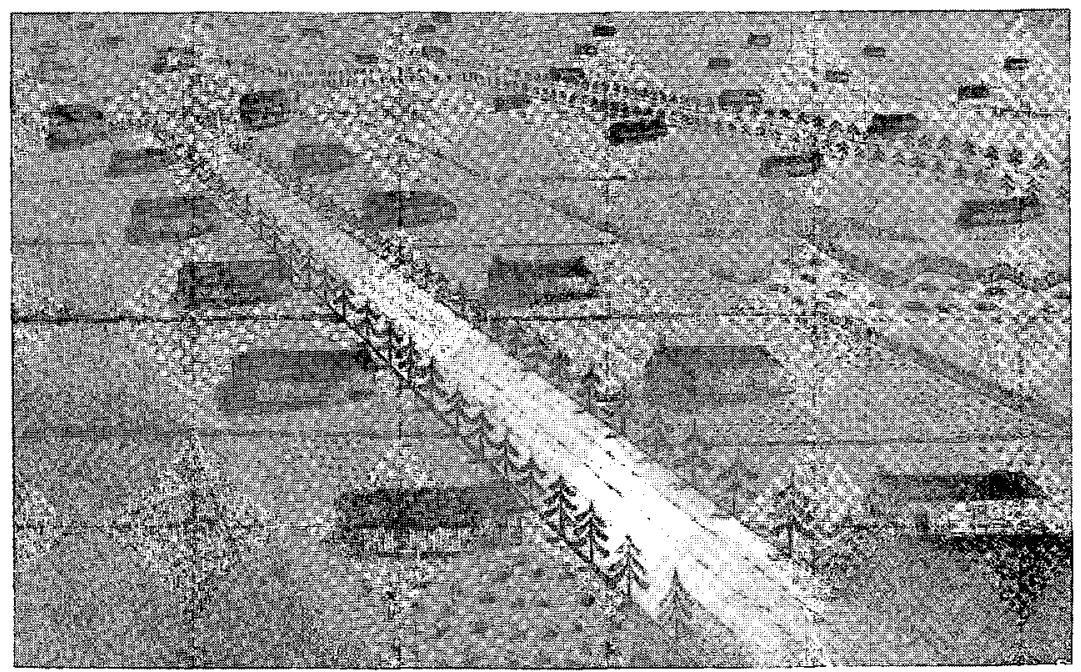


elke wijkmeester stonden weer twee sectiemeesters, één per sectie van I 2 woningen ${ }^{23}$. De onderdirecteuren, wijk- en sectiemeesters woonden in hun respectieve kolonie, wijk of sectie. Door deze spreiding van de ambtenaren over de koloniën werd het nadeel van de ongunstige ruimtelijke situatie zo veel mogelijk opgeheven.

Bij de administratieve reorganisatie in I 826 zijn de oorspronkelijke zes koloniën (I, II, III, IV, VI en VII) samengevoegd tot drie, genaamd Frederiksoord (uit I en II, voortaan I), Wilhelminaoord (uit IV en vII, voortaan II) en Willemsoord (uit III en vI, voortaan III). Kolonie I bestond sindsdien uit 3 wijken, evenals kolonie II; kolonie III was verdeeld in 4 wijken ${ }^{22}$. Het bedelaarsgesticht te Ommerschans stond aanvankelijk te boek als kolonie $\mathrm{v}$.

De cultuurgrond werd doorsneden door enkele hoofdwegen en andere wegen en een tweetal vaarten. Overigens lagen de gronden feitelijk in één kavel, al was deze dan van een eigenaardige vorm. Via kolonie vII was ten westen van Doldersum via de woeste grond van de Maatschappij ook een aaneensluitende ligging verkregen met Wateren. Het bij het Instituut voor den Landbouw behorende landbouwbedrijf bestond ten tijde van zijn grootste uitgestrektheid 24 waarschijnlijk uit vier complexen cultuurgrond, t.w. de ontginningsgrond (bouwland) rond het Instituut, het oudere bouwland van de zes aangekochte boerderijen, het hierbij behorende groenland langs de Aa en het ontginningsgrasland van de Oude Willem. Het juiste aantal kavels is in verband met de doorsnijding door wegen en stroompjes niet te bepalen. De ontginningscomplexen waren rechthoekig van vorm, zoals men nu nog in het terrein kan waarnemen. De grootste kavelafstand, van het Instituut tot de Oude Willem, bedroeg $\pm 5 \mathrm{~km}$.

Over de verkaveling van de kolonistenhoeven is in de vorige paragraaf reeds het een en ander opgemerkt. Elke hoeve bestond uit slechts één rechthoekige kavel. Een algemeen overzicht van de verkaveling van de eigendommen der Maatschappij per kadastrale sectie geeft de tabel op blz. 5o. De kadastrale percelen bouwland vormden tevens de kolonistenhoeven in de gemeenten Vledder, Steenwijkerwold en Weststellingwerf.

De gemiddelde kadastrale perceelsgrootte van het bouwland is niet ongunstig te noemen: het overgrote gedeelte van de bouwlandpercelen was $2-3$ ha groot. Dit in tegenstelling tot het grasland, overwegend madeland, waarvan de perceelsgrootte in de meeste gevallen de 2 ha niet te boven ging.

De kolonistenhoeven waren echter niet als evenzovele percelen in cultuur. Volgens de eerste reglementen van Van den Bosch werd elke 
Tabel 4 - AANTAL PERCELEN CULTUURGROND EN PERCEELSGROOTTE I825/33

\begin{tabular}{|c|c|c|c|c|c|c|c|}
\hline \multirow[b]{2}{*}{ Gemeente; jaar } & \multirow[b]{2}{*}{ Sectie } & \multicolumn{2}{|c|}{ Bouwland } & \multicolumn{2}{|c|}{ Hooiland } & \multicolumn{2}{|c|}{ Weiland } \\
\hline & & $\begin{array}{c}\text { aantal } \\
\text { per- } \\
\text { celen }\end{array}$ & $\begin{array}{l}\text { gemidd. } \\
\text { opp. } \\
\text { in ha }\end{array}$ & $\begin{array}{c}\text { aantal } \\
\text { per- } \\
\text { celen }\end{array}$ & $\begin{array}{c}\text { gemidd. } \\
\text { opp. } \\
\text { in ha }\end{array}$ & $\begin{array}{c}\text { aantal } \\
\text { per- } \\
\text { celen }\end{array}$ & $\begin{array}{c}\text { gemidd. } \\
\text { opp. } \\
\text { in ha }\end{array}$ \\
\hline \multirow[t]{3}{*}{ Vledder ( 1825$)$} & Doldersum & 24 & 3,6 & 22 & $\mathbf{I}, \mathbf{I}$ & 3 & 1,3 \\
\hline & Frederiksoord & 160 & 2,4 & - & - & 8 & 2,8 \\
\hline & Nijensleek-O. & - & - & - & - & 2 & 2,5 \\
\hline \multirow[t]{2}{*}{ Diever (1 826) } & Wateren & $3^{8}$ & $2, I$ & 4 & 3,7 & 14 & 0,9 \\
\hline & Kalteren & - & - & - & - & $\mathbf{I}$ & 4,0 \\
\hline \multirow{5}{*}{$\begin{array}{l}\text { Steenwijkerwold } \\
\quad\left(183^{\circ}\right)\end{array}$} & Kolonie & & & & & & \\
\hline & Willemsoord & 143 & 2,7 & - & - & - & - \\
\hline & Vierde Wijk & 16 & 2,9 & - & - & - & - \\
\hline & Eesveensche & & & & & & \\
\hline & Hooilanden & - & - & 6 & 1,5 & - & - \\
\hline Smilde (I 833 ) & & 3 & 1,3 & - & - & 4 & 0,3 \\
\hline $\begin{array}{l}\text { Ooststellingwerf } \\
(1833)\end{array}$ & Oosterwolde & ro & 0,8 & 4 & 1,3 & 4 & 0,8 \\
\hline \multirow{4}{*}{$\begin{array}{l}\text { Weststellingwerf } \\
\quad\left(\begin{array}{l}1 \\
1\end{array} 33\right)\end{array}$} & Noordwolde & $4^{I}$ & 2,7 & - & - & - & - \\
\hline & Kolonie & 37 & 2,9 & - & - & - & - \\
\hline & Boyl & 13 & 2,6 & - & - & - & - \\
\hline & Steggerda & I I & $x, 8$ & - & - & 2 & 0,0 \\
\hline
\end{tabular}

Bron: zie tabel 2.

hoeve van \pm 3 ha verdeeld in niet minder dan 7 gebruikspercelen, waarvan 2 percelen van 100 roeden $(=14,2$ are) waren bestemd voor afwisselend moestuin en vroege aardappelen, 4 percelen van 400 roeden $(=56,8$ are) voor akkerbouwgewassen en één perceel van 300 roeden $\left(=42,6\right.$ are) voor uitsluitend groenvoedergewas ${ }^{25}$. Figuur 3 brengt de perceelsindeling globaal in beeld.

Feitelijk was volgens deze percelering sprake van een vijfslagstelsel (de klaver etc. was tweejarig). Over de ontwikkeling in de toegepaste vruchtwisseling zal elders uitvoeriger worden gesproken (hoofdstuk IV, 2, b). Wel is hier van belang te constateren, dat de eerste opzet in de praktijk ingrijpend is gewijzigd. Zo zijn ook andere akkerbouwgewassen ingevoegd, terwijl de klaverweide vierjarig is geworden. Door deze oorzaken werd de perceelsindeling van de hoeven gaandeweg ingewikkelder. Het aantal percelen vermeerderde en de perceelsgrootte nam af. 


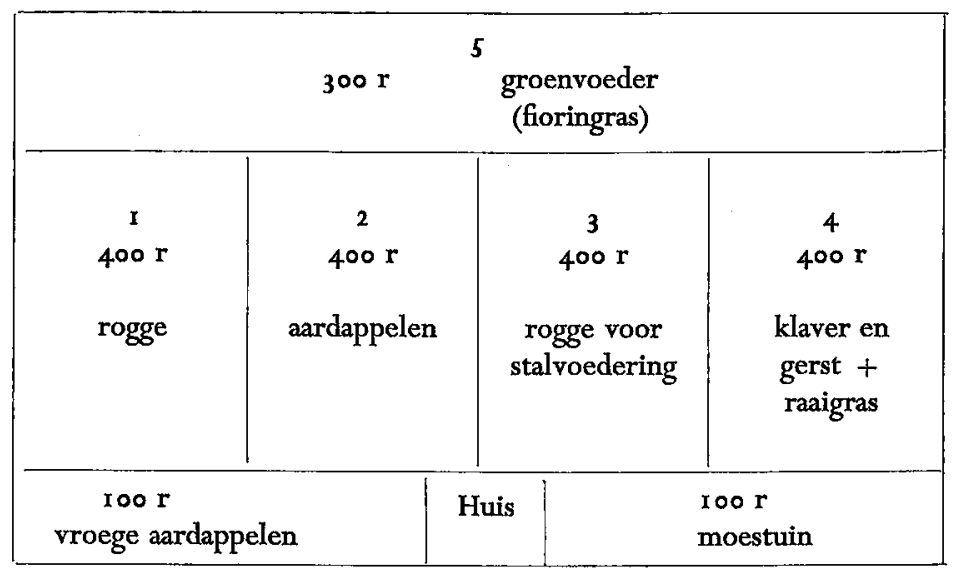

Fig. 3. Perceelsindeling van de kolonistenhoeven in 1820 .

In een beschrijving van de koloniën, die het bestuur van de Maatschappij in $\mathrm{I} 84^{\circ}$ publiceerde, is sprake van vijf opvolgende gewassen, waarvoor de grond van elke hoeve in vijf gelijke percelen zou zijn verdeeld ${ }^{26}$. Deze indruk krijgt men althans bij lezing van dit geschrift. Zo eenvoudig was de perceelsindeling van de hoeven echter niet.

Staring leidde in 1846 uit de destijds geldende voorschriften af, dat in de gewone koloniën feitelijk een vruchtwisseling van niet minder dan 18 slagen bestond, waartoe de hoeven dus in 18 perceeltjes moesten zijn verdeeld 27. Deze conclusie is in 1859 bevestigd door de directeur Van Konijnenburg 28 .

Het behoeft dan ook geen verwondering te wekken, dat de Groninger hoogleraar H.C. van Hall na zijn inspectie van de koloniën in 1848 als gecommitteerde van de Commissie van Toezicht in één van zijn I 2 punten van kritiek stelde, dat het wenselijk was „de kleine en veel verspreide stukken land in de gewone Koloniën zoo veel mogelijk tot grootere te vereenigen". De Permanente Commissie oordeelde echter, dat dit bezwaarlijk kon geschieden, omdat een dergelijke ingreep in strijd zou zijn met de inrichting en de indeling van de koloniën. Bovendien was zo'n verandering "minder oorbaar", omdat de grond meestal met de kantschop werd bewerkt en zelden een ploeg werd gebruikt ${ }^{29}$. Het bestuur wilde van geen verandering weten!

Over de percelering in 1859 schreef de nieuwe directeur Jongkindt Coninck in I 865, dat elke hoeve van omstreeks 2,7 ha was verdeeld in 20-50 akkertjes, gescheiden door brede greppels; elk akkertje droeg een 
afzonderlijk gewas ${ }^{30}$. De gemiddelde oppervlakte van de perceeltjes liep dus uiteen van $\pm 0,05-0$, I ha.

Men kan derhalve constateren, dat de zo sterke reglementering van de landbouw tot gevolg heeft gehad, dat de perceelsindeling in de vrije koloniën in 1859 was ontaard in een ondoelmatig legpuzzelpatroon van zeer kleine percelen, dat een rationele exploitatie volledig in de weg stond. Enig verbruik van paardewerktuigen was praktisch onmogelijk.

\section{ONTSLUITING}

Onder dit hoofd zal eerst de wegaanleg aan de orde komen. Omdat ook het vervoer te water voor de koloniën van betekenis is geweest, zal vervolgens worden ingegaan op de aanleg van kanalen.

Een betrekkelijk gedetailleerd beeld van de ontsluiting van het kolonisatiegebied door de wegen verkrijgt men uit de reisbeschrijving van Von Grouner ${ }^{31}$. Alvorens men overging tot de ontginning van de woeste grond en de bouw van de kolonistenwoningen, werd de heide doorsneden door in het algemeen rechte wegen, waarlangs de hoeven op regelmatige afstanden werden geprojecteerd. De bij de wegaanleg toegepaste methode was van veel belang in verband met de moerassige plaatsen. Bij sterke regenval waren de wegen dikwijls zeer slecht. Aanvankelijk werd het wegtracee ter breedte van $36-40$ voet in het veld uitgezet, de heide afgeplagd en tenslotte bezand met het zand uit de bermsloten. Deze waren 2-3 voet diep, terwijl de breedte afnam van 6 tot $2 \frac{\mathrm{I}}{2}$ voet. Zo nodig voerde men meer zand van elders aan. Het gebeurde echter vaak, dat het zand spoedig in de veengrond was verdwenen, ook nadat het drie- of viermaal achtereen was opgebracht. Eindelijk adviseerde een boer uit de omgeving de nieuwe wegen op veenachtige plaatsen niet af te plaggen, maar andere plaggen omgekeerd op de heide te brengen en hierop zand te storten. Deze methode voldeed goed.

Voor het zandtransport gebruikte men kipkarren, getrokken door één paard, met twee grote wielen en één klein, massief voorwiel of een houten steun aan de voorzijde. Deze steun was niet opklapbaar. Het was een latere verbetering die beter beviel dan een derde wiel ${ }^{32}$. Von Grouner vermeldde, dat tweewielige kipkarren ook elders in Nederland, evenals in Beieren, in gebruik waren. Op vele andere plaatsen waren zij echter destijds nog onbekend. De driewielige kar of de tweewielige met stelt kende men echter ook in Beieren niet. Bij de wegaanleg gebruikte de Maatschappij drie van deze karren met twee paarden, die van kar ver- 
wisselden. Twee jongens laadden de grond op de karren, terwijl twee mannen heen en weer reden en de grond aflaadden.

De vrije koloniën werden doorsneden door twee belangrijke verbindingswegen, nl. de straatweg van Steenwijk via Willemsoord naar Wolvega, Heerenveen en Leeuwarden en de weg Steenwijk-NijensleekFrederiksoord-Vledder-Diever, vanwaar men langs de Smildervaart Assen bereikte. Het wegtransport naar de koloniën langs de eerstgenoemde weg moest te Willemsoord een tol passeren, die een aanzienlijke financiële last betekende voor de Maatschappij. In 1833 werd de tol voor II maanden door de Maatschappij gepacht voor $f 531,67$, hetgeen een zekere besparing betekende. De tolgaarder ontving van de Maatschappij per week $f 2,5^{\circ}$ gaarloon ${ }^{33}$.

Zoals eerder is aangegeven ${ }^{34}$, was de Maatschappij o.a. belast met het onderhoud van de wegen Frederiksoord-Vledder, FrederiksoordNoordwolde en Frederiksoord-Wapserveen, zover haar bezittingen zich uitstrekten, incl. de brug over de Vledder Aa bij Wapserveen. Deze verplichtingen brachten ook de nodige kosten met zich mede. Zo moest men in $\mathrm{r} 844$ over de Aa een nieuwe brug leggen ${ }^{35}$. In de winter van $x 845$ op I 846 is een nieuwe rechte weg aangelegd van het Instituut voor den Landbouw naar Groot Wateren in plaats van de oorspronkelijke slechte en bochtige weg ${ }^{36}$. Alle wegen in de koloniën waren toentertijd nog zandwegen. Zij werden blijkbaar goed onderhouden. Staring trof ze in I 846 „over het algemeen in zeer voldoenden toestand" aan ${ }^{37}$. Het Algemeen Verslag over 1852 bevat de mededeling, dat voor de egalisering van de wegen een z.g. wegsleper was aangeschaft, die, door ossen getrokken, sneller werk gaf. Men was voornemens nog een tweetal te kopen, zodat elke kolonie over één wegsleper zou kunnen beschikken.

De eerste weg, die werd verhard tot „kunstweg”, was de verbindingsweg Steenwijk-Frederiksoord-Vledder (1 857). Hiertoe is een intergemeentelijke commissie ingesteld door de gemeenten Steenwijk, Steenwijkerwold en Vledder. Bijdragen voor de verharding zijn verstrekt door het Rijk, de provinciale besturen en de Maatschappij van Weldadigheid ${ }^{38}$. In I 834 was deze weg reeds enigszins verhard met grint.

Van den Bosch hechtte veel waarde aan de aanwezigheid van vaarwater in de koloniën. Reeds bij het begin van de kolonisatie was de Westerbeeksloot, de verbinding van Frederiksoord met de Vledder Aa, in bevaarbare staat gebracht en in de richting van het latere Wilhelminaoord verlengd. In $1819 / 20$ waren er twee houten sluizen in deze vaart met optrekbare schuiven in verband met het verval, dat $5^{-6}$ voet be- 
droeg. Schepen met een lading van 30-50 voer hooi konden deze sluizen passeren. Elke sluis was voorzien van een brug39.

Von Grouner noemt als tweede soort bruggen de afzonderlijke houten bokbruggen, die rustten op twee bokken, welke in de vaart stonden, en voldoende hoog waren om de schepen door te laten. Tenslotte zag hij nog een derde soort bruggen, die waren gemaakt van heideplaggen en in de bermsloot voor elke kolonistenwoning lagen. Iedere kolonist kon een dergelijke brug in één dag leggen. Om de drie jaren moesten zij worden vernieuwd.

Ten behoeve van de verdere ontginning wilde Van den Bosch een kanaal laten graven van Blokzijl via Steenwijk naar Groningen. Hiertoe waren in 1820 reeds opmetingen verricht 40 ; het plan is echter nooit uitgevoerd. Loodrecht op de Kolonievaart of Noordwoldigervaart heeft de Maatschappij langs de Friese grens twee zijkanalen gegraven in de West- en Oostvierdeparten, waardoor deze beide gedeelten van Wilhelminaoord over een verbinding te water met Noordwolde en de Linde beschikten. Laatstgenoemd riviertje stroomt in zuidwestelijke richting naar de voormalige Zuiderzee.

Vooral in de jaren na 1830 is aan het kanalenstelsel in de koloniën hard gewerkt. In augustus I 832 kon men melden, dat de vaarten te Wilhelminaoord langs de Friese grens in goed bevaarbare staat waren gebracht ${ }^{4} \mathrm{r}$. Tegen het einde van het volgend jaar was de verlengde vaart van Noordwolde naar Frederiksoord voor een derde gedeelte door de kolonisten bevaarbaar gemaakt in één jaar tijds. $\mathrm{Na}$ de herfstregens was dit deel van de vaart in gebruik. Het volgende traject is in de winter $1833 / 34$ onder handen genomen ${ }^{42}$. Het Algemeen Verslag over I 834 kon dan ook vaststellen, dat de Noordwoldigervaart was doorgetrokken tot in kolonie I bij de oude boerderij van de winkelier Kremer. Verder was de zijtak in de Westvierdeparten verlengd tot aan de Steggerdervierdeparten (in kolonie III ten zuidoosten van Steggerda). Aldus kon men de turf, die werd gestoken in het Doldersummerveen, door de vaart naar Willemsoord vervoeren. Het Algemeen Verslag over 1835 geeft aan, dat de bodembreedte van de vaart 4 el bedroeg, terwijl de waterspiegel bijna 8 el breed was, indien het water op peil stond. Sedert januari 1836 was voldoende water aanwezig en konden de schepen met een gewone lading (o.a. hooi en turf) vanaf de Linde via Noordwolde tot het bos bij het huis Westerbeek varen, in november 1836 tot het logement te Frederiksoord. 43

Toch bleek het moeilijk het water in de kanalen gedurende het gehele jaar op peil te houden. Het Algemeen Verslag over I 837 vermeldt $\mathrm{nl}$. reeds, dat men veel hinder ondervond van het feit, dat zij pas in november 
bevaarbaar werden. De mest was daardoor soms te laat aanwezig in kolonie I en II om de winterrogge op tijd te kunnen zaaien. Dit klemde des te meer, omdat "genoegzaam al de mest" toentertijd werd aangekocht. Ook was de afvoer van aardappelen en turf bij watergebrek te laat mogelijk, zodat men op vervoer per as was aangewezen.

Staring constateerde in 1846 , dat de vaarten, in zoverre de Maatschappij daarover kon beschikken, goed werden onderhouden. Hij betreurde evenwel, dat de uitbreiding van de kanalisatie werd belemmerd door oorzaken, die buiten de Maatschappij lagen. Staring doelde o.a. op de aanleg van een kanaal Frederiksoord-Steenwijk, die schijnbaar door tegenstrijdige particuliere belangen werd tegengehouden ${ }^{44}$.

Reeds eerder is vermeld45, dat in 1855 aan de uitmonding van de Kolonievaart in de Vledder Aa een korenmolen is gebouwd, die tevens water uit de Aa moest opmalen. Ook deze maatregel was echter niet afdoende om scheepvaart gedurende het gehele jaar mogelijk te maken.

\section{PACHTVERHOUDINGEN}

Met het onderwerp van de pachtverhoudingen tussen de Maatschappij van Weldadigheid enerzijds en de kolonisten anderzijds betreedt men het terrein van de sociaal-economische omstandigheden, waaronder de koloniale bevolking leefde. Dit punt dient men te zien in nauwe relatie met de arbeidsverhoudingen, die in hoofdstuk $\mathrm{v}$ aan de orde zullen komen.

Uit de eerste Verhandeling van Van den Bosch46 blijkt op verscheidene plaatsen, dat hij zich aanvankelijk voorstelde, dat elke kolonist moest kunnen bestaan van de opbrengst van zijn (pacht-) bedrijfje van \pm 3 ha, dat hij voor eigen rekening zou moeten beheren. Vanaf het derde jaar wilde hij ieder gezin een pachtsom van $f 25$,- per jaar laten betalen, hetgeen minder dan de helft van de normale pachtwaarde zou zijn ${ }^{47}$. Als men aan de veldarbeid gewend was, diende ieder zijn eigen grond te bewerken en de produkten zelf te oogsten. Van den Bosch huldigde in dit opzicht een gezond principe: hij wenste „het eigenbelang dienstbaar te maken aan de bevordering der arbeidzaamheid". Wel was zijns inziens een uniform werkprogramma nodig, dat onder toezicht moest worden uitgevoerd48. In de hier aangehaalde Verhandeling gaf Van den Bosch reeds een gedetailleerd werkplan voor de eerste drie jaren na de vestiging van de kolonisten. Aan het einde van dit geschrift, gepubliceerd voordat de koloniën werden gesticht, maakte hij evenwel een belangrijk voorbehoud: „De tijd alleen kan leeren, in hoeverre de vruchten, die 
ieder van zijnen akker oogst, aan zijne eigene beschikking zullen kunnen worden overgelaten"49. In geval van verkwisting moest de Maatschappij het recht van curatele kunnen uitoefenen.

Over de oorspronkelijke plannen van Van den Bosch treft men in de literatuur ook verdergaande denkbeelden aan. Zo schreef Quarles van Ufford in 1859 , dat het aanvankelijke voornemen van de stichter was de kolonisten na een zekere reeks van jaren de hoeven in eigendom te geven, wanneer zij hun schuld aan de Maatschappij, aangegaan in verband met de kosten van vestiging, zouden hebben afgelost. Dit bleek volgens schrijver echter spoedig een utopie te zijn ${ }^{50}$.

Eilerts de Haan vermeldde echter, dat het doel der stichters was alle kolonisten langzamerhand tot vrije of zelfstandige pachters of vrijboeren te maken. "Zij beschouwden ditals de kroon op hun opvoedingssysteem" ${ }^{5 I}$. De kolonisten hadden het vooruitzicht, dat zij door vlijt en een goed gedrag van kolonist-arbeider konden worden bevorderd tot vrijboer. De vrijboeren moesten een jaarlijkse pacht van $f 60,-$ betalen, waarvoor zij het vrije gebruik van de hoeven verkregen, hoewel onder toezicht van de Maatschappij, en de vrije beschikking over hun oogst. Dit was met de kolonisten-arbeiders niet het geval : zij bewerkten de achter hun hoeven gelegen grond voor rekening der Maatschappij, waarvan zij een arbeidsloon ontvingen. Aldus de werkelijke gang van zaken volgens Eilerts de Haan, die derhalve duidelijk onderscheid maakte tussen de kolonistenarbeiders en de vrijboeren (pachters).

Westendorp Boerma geeft in grote trekken dezelfde beschrijving van de pachtverhoudingen. Hij noemt echter een pachtsom van $f_{50}$,- - voor de vrijboeren (gelijkstaande met $1 / 3$ gedeelte van de oogst) ${ }^{52}$. De arbeiders hadden alleen de beschikking over hun tuingrond en hun arbeidsloon.

Het eigenaardige van de pachtverhoudingen is zeker gelegen in het feit, dat men op grond van de literatuur en archiefstukken tot de conclusie komt, dat elke kolonist, zowel arbeider als vrijboer, een gelijke pachtsom moest betalen. Dit wil dus zeggen, dat de arbeiders minder netto-inkomsten moeten hebben gehad dan de vrijboeren, die hun bedrijfjes goed beheerden. Van den Bosch deelde in zijn tweede Verhandeling mede, dat alleen de ontginning in gezamenlijke arbeid geschiedde, tegen hetzelfde tariefloon (naar prestatie) als in de omgeving van de koloniën, terwijl de kolonisten vervolgens zelf hun eigen grond moesten bewerken. Blijkbaar moesten zij dan $f_{50}^{\circ}$, - pacht betalen, een bedrag als aflossing voor de bij de vestiging ontvangen voorschotten, fo, 10 per week voor de koe, die zij van de Maatschappij voor eigen ge- 
bruik hadden gekregen en een klein deel van de opbrengst van de verkoop van de kalveren door de kolonist 53 .

De weg van de positie van kolonist-arbeider naar het vrijboerschap legde de kolonist in een drietal fasen af. De eerste stap had hij gezet, wanneer hij de helft van de aanvangsschuld had afgelost. Dan ontving hij een koperen medaille. Wanneer de gehele schuld was afbetaald en de kolonist-arbeider zich goed gedroeg, werd hij onderscheiden met een zilveren medaille. Hij had dit in geval blijk gegeven door zijn arbeid in eigen behoeften te kunnen voorzien. De dragers van een zilveren medaille, die in één jaar minstens $f 250$, - netto-inkomsten hadden verkregen uit hun bedrijfje, kregen tenslotte een gouden medaille en een bevordering tot vrijboer. De medailles werden aan een oranje lint gedragen op de linkerborst. De Permanente Commissie verleende de medailles op voordracht van de directeur en kon ze op dezelfde wijze intrekken. De directeur mocht het laatste op eigen gezag tijdelijk doen voor I 5 dagen. Om de twee weken organiseerde de directie een feestelijke bijeenkomst, waartoe alle kolonisten met goed gedrag werden uitgenodigd. Bij deze gelegenheid reikte de directeur de medailles uit, c.q. trok ze in 54 .

De pacht voldeed men doorgaans in natura, waarbij de Maatschappij de prijs van de produkten vaststelde. De oogst vormde feitelijk het onderpand voor de betaling van de verschuldigde bedragen aan de Maatschappij.

In de Huishoudelijke bepalingen voor de vrije koloniën, opgesteld in I 822 en aangehaald door Von Grouner55, kwamen uitvoerige voorschriften voor terzake van de pachtbetaling en de verdeling van de oogst tussen Maatschappij en kolonisten. Hieruit blijkt in de eerste plaats, dat de aanvankelijke opzet alle werk door de kolonisten op hun eigen bedrijfjes afzonderlijk te laten verrichten, toen is vervangen door gemeenschappelijke arbeid per sectie van I 2 gezinnen onder toezicht van de sectiemeester tegen betaling van loon. Voor de arbeid van andere kolonisten op zijn eigen hoeve moest elke kolonist $f 50,-$ per jaar terugbetalen aan de Maatschappij, welk bedrag werd gestort in het Fonds voor den Veldarbeid. Uit de eerste oogst zonderde de Maatschappij voor haarzelf af: zaaizaad voor twee jaren, 160 schepels van 40 pond aardappelen voor wintervoorraad en 36 schepels rogge. De rest van de oogst werd gelijkelijk verdeeld tussen de Maatschappij en de kolonist. Van de tweede oogst ging $\mathrm{I} / 3$ deel naar de Maatschappij voor pacht en genoemd Fonds. Van de volgende oogst ontving de Maatschappij produkten ter waarde van $f 5^{\circ}$, - voor pacht, nog eens $f 5^{\circ}$, - voor het Fonds en 
bovendien een waarde van $f 25,-$ voor schuldaflossing. Het restant kon de kolonist zelf behouden.

Degenen, die na drie jaren nog geen medaille bezaten, moesten per jaar bij het magazijn van de Maatschappij inleveren :

I. voor pacht en het Fonds voor den Veldarbeid $f$ roo,- aan produkten;

2. 36 schepels rogge of ander graan, waarvoor het gezin dagelijks 6 pond brood ontving;

3. I 60 schepels aardappelen, waarvan aan elk gezin vanaf i november tot I augustus wekelijks 4 schepels werd uitgereikt;

4. voor $f 25$, - waarde aan produkten voor schulddelging;

5. $f \circ$, I o per ontvangen gulden arbeidsloon voor administratiekosten;

6. de helft van zijn arbeidsloon voor schuldaflossing.

Hetgeen na aftrek van het bovenstaande overbleef, mocht de kolonist voor zichzelf behouden.

Deze ingewikkelde regeling, van toepassing op de kolonisten-arbeiders, bevat zowel elementen van een pachtverhouding als van een arbeidsverhouding met de Maatschappij. De vrijboeren daarentegen betaalden alleen $f 5^{\circ}$,- pacht (in natura) en ontvingen geen loon voor hun veldarbeid.

De meeste kolonisten bleken echter niet in staat hun schulden af te lossen en bleven derhalve kolonist-arbeider. Zelfs nam de totale schuldsom geregeld toe ${ }^{56}$. De algemene stelregel, die men op verschillende plaatsen in de literatuur tegenkomt ${ }^{57}$, dat de oogst het eigendom was van de kolonisten, had in de praktijk dus slechts een zeer beperkte betekenis. Er was doorgaans geen restant van de oogst voor de kolonist zelf over, nadat hij zijn betalingen had gedaan. De tekorten groeiden aan, waardoor de Maatschappij beslag legde op de gehele oogst van vele kolonisten, zodat deze in feite alleen nog in een arbeidsverhouding stonden tot de Maatschappij.

In het Verslag over de staat der koloniën in $1823^{58}$ komt weliswaar de aanbeveling voor de mogelijkheid te overwegen mettertijd oppassende kolonisten in de vrije koloniën niet alleen in staat te stellen daar als permanente pachters te wonen, maar ook door jaarlijkse aflossing van het kapitaal de gelegenheid te verschaffen eens eigenaar te worden van land en woning, maar deze suggestie was in het geheel niet uitvoerbaar.

Het systeem van bevordering tot vrijboer is tot 1859 slechts weinig toegepast. Eerst in het Algemeen Verslag over 1828 wordt over de resultaten iets medegedeeld. Men had het bezwaar ondervonden, dat de hoeven van de vrijboeren veelal niet meer behoorlijk werden bebouwd, doordat zij ook elders gingen werken. De Maatschappij wilde 
echter nog eens een proef nemen met 20 vrijboeren. De directie diende voor de bebouwing van hun hoeven de nodige zorg te dragen; zij werden op voorschot voorzien van voldoende veevoer voor de winter en zij moesten tevens het nodige stalvoer verbouwen. De vrijboeren mochten alleen elders werken, als het bedrijf dit naar het oordeel van de directie toeliet. Enerzijds blijkt uit de drang bijverdiensten te verwerven, dat vóór I 828 reeds in de praktijk bleek, dat de bedrijfjes te klein waren om een gezin een volledig bestaan te verschaffen. Anderzijds tonen de genoemde voorschriften aan, dat de vrijboeren geenszins als vrije pachters zijn te beschouwen. Dat men slechts weinig kolonisten tot vrijboer ( „kolonist van den eersten rang”) kon bevorderen, werd in genoemd Verslag gerechtvaardigd met de opmerking: „... verre weg de meesten toch waren, bij hunne aankomst, niet alleen weinig tot den arbeid geschikt, maar nog bovendien ijverloos, onbedreven, verkwistend of verslaafd aan den drank."

Het Algemeen Verslag over 1830 bevat de opmerking, dat over de proef met \pm 20 vrijboeren nog geen definitief oordeel kon worden gegeven. Tegenslagen in de landbouw maakten het zelfstandige bestaan op de hoeven moeilijk.

De subcommissie uit de Commissie van Toezicht, die de koloniën in I 838 inspecteerde, maakte melding van de in $1837 / 38$ aan de vrijboeren opgelegde verplichting per jaar $f 20$, - te betalen als aandeel in de kosten van algemeen beheer, onderwijs en geneeskundige dienst59. De subcommissie merkte voorts op: „... de ondervinding heeft geleerd, dat slechts weinige Kolonisten op den duur in staat zijn in de bebouwing voor eigene rekening, die als bijzonder voordeelig voor de Maatschappij schijnt beschouwd te moeten worden, hun bestaan te vinden..." Zij verwachtte dan ook een afneming van het aantal vrijboeren.

De volgende inspectiecommissie, die de koloniën in 1839 bezocht, merkte in haar verslag op, dat het uitreiken van medailles aan kolonisten, die zich onderscheidden, om onbekende redenen was afgeschaft. De commissie pleitte voor wederinvoering.

Blijkbaar bestond echter nog wel de mogelijkheid vrijboer te worden. Het Algemeen Verslag over i 839 maakt nl. gewag van het feit, dat vele kolonisten het vrijboerschap ambieerden. Daarom stelde de Maatschappij enige nieuwe bepalingen vast om haar belangen te verzekeren en het verband te bewaren tussen de landbouw van de vrijboeren en het algemene cultuurstelsel voor de gewone koloniën. Men mag derhalve aannemen, dat de (weinige) vrijboeren een nog geringere mate van vrijheid behielden ten aanzien van hun bouwplan etc. In haar brochure van I $84^{\circ}$ 
zegt de Maatschappij, dat de vrijboeren onderworpen bleven aan de algemene regels voor de koloniale landbouw 60 .

Het Algemeen Verslag over I $84^{\circ}$ somt enige bepalingen op uit het nieuwe reglement voor de vrijboeren. Zij moesten zelf geheel in hun behoeften voorzien. Voor de tweede maal is sprake van toestemming, ook voor hun gezinsleden, buiten de koloniën te gaan werken. Wederom een bewijs, dat de bedrijfjes te klein waren voor het normale levensonderhoud. Voortaan zou de Maatschappij alleen nog extra werkgelegenheid verschaffen aan de kinderen van de vrijboeren in de katoenweverij. De niet ontgonnen gedeelten van de vrijboerenhoeven zou men in cultuur brengen op kosten van de Maatschappij, waarvoor deze de eerste vrucht zou ontvangen; vervolgens hadden de vrijboeren het volledige gebruik van de grond. $Z_{i j}$, die „niet genoegzaam vee” hielden, waren verplicht een deel van de grond op eigen kosten en onder toezicht van de directie met brem te bezaaien ${ }^{6 x}$. De vrijboeren moesten hun overtollige rogge en aardappelen tegen marktprijs aan de Maatschappij verkopen. De jaarlijkse pacht werd vastgesteld op $f 25$, -, vermeerderd met $f 20$, - voor onderhoud van de boerderij, geneeskundige hulp en onderwijs. Fabius ${ }^{2}$ noemde in $\mathrm{r} 84 \mathrm{I}$ dan ook als pachtsom $f 45$, 一, hoewel dit niet geheel juist is, daar men de tegemoetkoming in de kosten van geneeskundige hulp en onderwijs niet als pachtelementen kan beschouwen.

Staring en Quarles van Ufford waren in I 846 van mening, dat de ondervinding van bijna dertig jaren had bewezen, dat het onmogelijk was de kolonisten op te leiden tot onafhankelijke vrijboeren: „... men mag het oorspronkelijke plan van den stichter der koloniën ten dien aanzien als geheel mislukt beschouwen"63.

Het Algemeen Verslag over I $85^{\circ}$ vermeldt, dat het de kolonisten reeds sedert een aantal jaren (waarschijnlijk sinds de jaren ' 30 ) was toegestaan veenboekweit te verbouwen op het veld van de Maatschappij buiten de eigenlijke koloniën, o.a. op het Dieverveld. Zij moesten dit doen buiten de gewone werktijd. De Maatschappij ontving hiervoor de vierde garf, dus een pachtsom in natura.

$\mathrm{Na}$ Staring in 1846 gaf J. M'Neill uit Schotland in 1853 een beoordeling van de vrije $\cdot k o l o n i e ̈ n$ in een rapport, waaruit Willink in $\mathbf{1} 889$ enige citaten heeft overgenomen ${ }^{64}$. Hieruit blijkt, dat het aantal vrijboeren in 1848 nog 25 bedroeg, in 1853 niet meer dan 16 . De toestand van de vrijboeren beoordeelde $M$ 'Neill ongunstiger dan die van de „noncolonist neighbours", die een hogere pacht betaalden zonder de voordelen van de Maatschappij te genieten en zichzelf toch gemakkelijk konden onderhouden. Dit verschil was volgens de rapporteur te wijten 
aan de ongeschiktheid van een groot gedeelte der kolonisten voor de landbouw en aan het algemeen ontbreken van economisch inzicht. Zijn conclusie luidde dan ook, dat de vrije koloniën, gezien als een poging de gezinnen zichzelf te doen onderhouden, na een ondervinding van 34 jaren niet alleen "a complete failure” waren, maar "there was no reason to believe that the scheme could possibly have succeeded." M'Neill achtte het twijfelachtig, of het mogelijk zou zijn de koloniën zelfverzorgend te maken, zelfs als de kolonisten werden geselecteerd uit bevolkingsgroepen die geschikt waren voor het landbouwersberoep. Zijn uitspraak: „... the certainty that the Society will maintain them, whether they save or not, has an unfavourable influence on their habits", die zowel voor de vrijboeren als de arbeiders gold, bevat zeker wel een juiste gedachte, ofschoon men het feit, dat de Maatschappij als geheel (incl. de gestichten) destijds financieel in zeer moeilijke omstandigheden verkeerde, niet behoeft gelijk te stellen met een volledige mislukking. Het is echter evenzeer duidelijk, dat het vrijboerensysteem zeker geen succes is geweest in de beschouwde periode.

Aan het einde hiervan, in 1859 , bedroeg het aantal vrijboeren volgens Eilerts de Haan $^{65}$ en Van Welderen Rengers 66 slechts 20, terwijl in totaal 434 kolonistengezinnen in de vrije koloniën waren gevestigd. De in genoemd jaar afgetreden directeur Van Konijnenburg noemde een aantal van 25 vrijboeren bij de reorganisatie van de Maatschappij. Eén van zijn aanbevelingen was een pleidooi voor een grotere mate van opleiding van de kolonisten tot zelfstandigheid. $\mathrm{Z}_{\mathrm{ij}}$ waren z.i. te veel arbeiders gebleven. Ook was hij voorstander van een geleidelijke afschaffing van de voorziening van de kolonisten met brood, aardappelen, turf en hooi. Een verdere emancipatie van de bevolking achtte Van Konijnenburg noodzakelijk67. Deze weg is inderdaad ingeslagen door het Bestuur, dat optrad na de afscheiding van de bedelaars- en wezengestichten van de vrije koloniën in 1859 .

\section{BEDRIJFSGEBOUWEN EN WONINGEN}

De enige soort boerderijen in de gewone koloniën gedurende de periode I 8 1 8-1 859 was het vrijwel uniforme type kolonistenwoning, dat behoorde bij de hoeven van \pm 3 ha. Deze gebouwtjes bestonden uit een bedrijfs- en een woongedeelte, waarvan het bedrijfsgedeelte het eerst zal worden behandeld.

De volledigste beschrijving van de gebouwen is aan te treffen in de publikatie, waarin de reisgegevens van Von Grouner zijn verzameld 68. 
Hij maakte zijn reis door de Verenigde Nederlanden in de jaren I 82 I en I 822 , zodat hij de oudste modellen heeft beschreven. De bouwkosten van één woning met bedrijfsruimte kwamen op $f 500$,- - Aanvankelijk gaf de Maatschappij de bouw in akkoord aan aannemers, die de materialen over vrij grote afstand op eigen kosten moesten laten aanvoeren. Later kon Van den Bosch in de vrije koloniën zelf stenen bakken en kalk laten branden. Doordat dit goedkoper uitkwam, kon men de woongedeelten voor hetzelfde geld iets ruimer bouwen.

Het bedrijfsgedeelte of achterhuis werd opgetrokken van houten palen met muren van geteerde planken, die rustten op een lage stenen fundering. Deze was slechts ondiep in de grond gemetseld. Bij het oudste type was het achterhuis breder dan het woongedeelte. Elke kolonist kreeg aanvankelijk één koe en, in plaats van een tweede koe, ro schapen. De dieren stonden door elkaar in de stal, de koe vastgebonden tussen twee palen. De mestgang stond, evenals het sekreet, in verbinding met een gierbak, die aan de achterzijde van het gebouwtje was ingegraven. Het schuurgedeelte had een buitendeur in de rechter zijmuur. Onder het rieten dak was boven de woning een kamertje voor het opbergen van gereedschap.

Het z.g. nieuwe type had een achter- en voorhuis van gelijke breedte en een verbindingsdeur tussen beide gedeelten. De bijbehorende waterput was bekleed met heideplaggen; hij zou een roo-jarige periode kunnen doorstaan. Ter verbetering van de waterkwaliteit wierp men gebrande kalk in de put, nadat deze was uitgegraven. Von Grouner vroeg zich af of de heideplaggen niet nadelig waren voor de gezondheid.

Het woongedeelte van het eerste type bestond uit een woonkeuken $(4,5 \times 4,5 \mathrm{~m})$ en drie slaapruimten met twee boven elkaar gelegen bedsteden. Evenals de schuur had ook de woning aan de rechterzijde een buitendeur. De muren, geheel van steen opgetrokken, bevatten verder aan de voorzijde twee benedenramen aan weerszijden van de schoorsteen en twee zeer kleine bovenraampjes. In het iets grotere woonhuis van het nieuwere type waren $4 \times 2$, dus acht bedsteden. In de toegevoegde zijruimte had men twee kleine kamers gemaakt.

Hoewel Von Grouner in het algemeen vol lof was over de activiteiten van de Maatschappij van Weldadigheid, uitte hij reeds bedenkingen tegen de bouwwijze van de kolonistenwoningen: „Im Allgemeinen kann man die Colonisten-Wohnungen, besonders in Ansehung des zu sehr beschränkten Raumes, für den schwächsten Theil dieser grossartigen Unternehmung betrachten".

Over de kalkbranderij en steenbakkerij in de koloniën deelde hij nog 


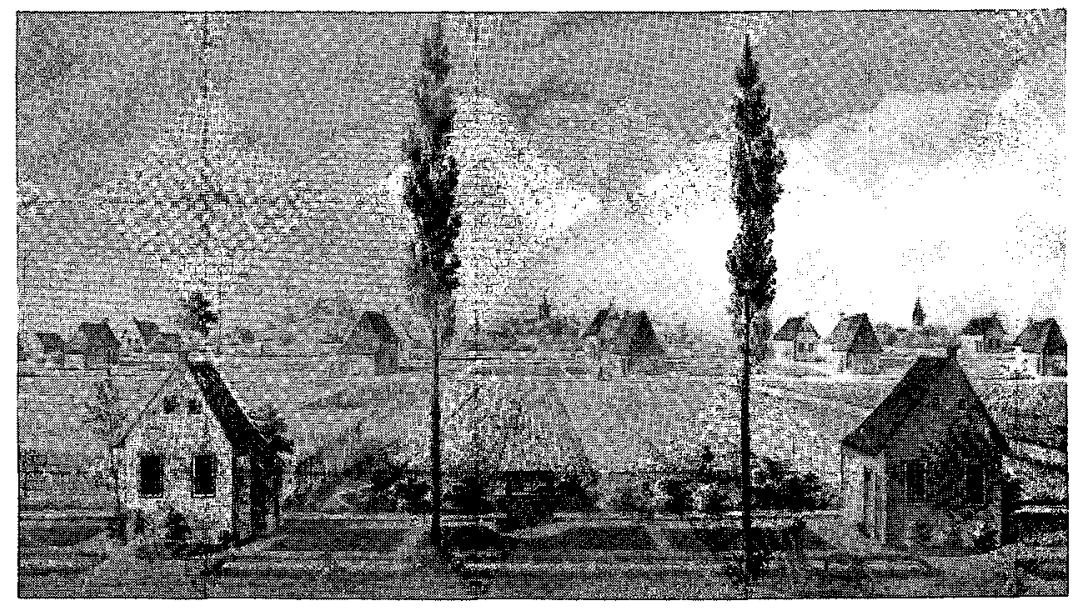

FI G. 4 - Gezicht op de vrije kolonie no. II (Willemsoord). Ontleend aan het tijdschrift De Vriend des Vaderlands, (Iv) r 830 , blz. 3 ro.

FrG. 5 - Indeling van de kolonistenwoningen (links: oudste type, rechts : vergroot type). Overgenomen uit Von Grouner, t.a.p., blz. $3^{00 .}$

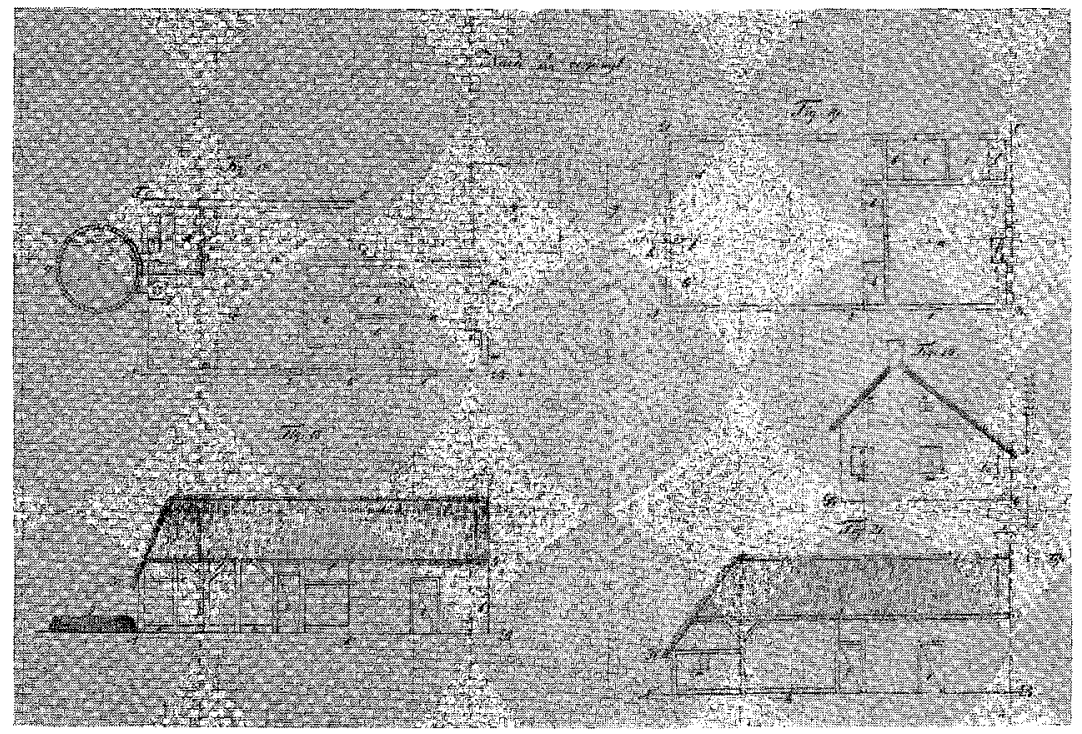



mede, dat de Maatschappij het grondbezit had onderzocht met de grondboor en op verscheidene plaatsen een leemlaag had aangetroffen, op een diepte van I 0-I 2 voet. De leem was wel sterk zandhoudend, maar van voldoende kwaliteit om bruikbare stenen van te bakken. In de omgeving van de koloniën was echter niemand, die dit kon doen. Van den Bosch liet daarom steenbakkers overkomen uit Eindhoven, die de kolonisten het vak leerden. Zowel de Eindhovenaren als de kolonisten bakten de stenen tegen akkoordloon. Men berekende alleen de arbeid; aldus bedroeg de kostprijs $f 5,25$ per 1000 gebrande stenen. De prijs van de vroegere aangekochte stenen was het dubbele. In plaats van de eerder gebruikte gebrande kalk liet Van den Bosch van de Zuiderzee schelpen aanvoeren, die eveneens in de openlucht met turf werden gebrand. Aan de aannemers verkocht hij de gebrande kalk tegen de in de omgeving geldende (hogere) prijs, aan de kolonisten voor bemestingsdoeleinden tegen de kostprijs.

Het behoeft geen verwondering te wekken, dat de kolonistenwoningen met hun muren zonder spouw ook de kritiek niet konden doorstaan van de zijde van de anonieme schrijver, die ruim zes jaren in de koloniën had gewerkt en in 1828 een brochure vol aanmerkingen het licht deed zien ${ }^{69}$. Uit de reacties van de Maatschappij blijkt70, dat de voormalige adjunctdirecteur van de laagste klasse Wardenburg de samensteller was van het geschrift. Zijn kritiek op de kolonistenwoningen luidt: „De huisjes der vrije Koloniën zoo min als de gestichten leveren eenig spoor op van die doelmatigheid of hechtheid, waardoor al de Hollandsche ondernemingen zich zoo voordeelig kenmerken".

Westendorp Boerma deelt bij zijn beschrijving van de kolonistenboerderijtjes o.a. mede, dat de bedsteden in de later gebouwde woningen (hij geeft een plattegrond weer van omstreeks I 827) werden vervangen door kleine kamertjes $7 \mathrm{r}$. Het komt waarschijnlijker voor, dat men de bedsteden in plaats van in de huiskamer in afzonderlijke slaapkamertjes ging bouwen.

Dat de kolonistenwoningen niet in alle opzichten voldeden aan redelijke eisen ten aanzien van de volksgezondheid, blijkt uit het verslag van de subcommissie uit de Commissie van Toezicht, die de koloniën in juli $\mathrm{I} 835$ bezocht. Hierin treft men een pleidooi aan voor de vervanging van de stenen tegelvloeren door houten ter bevordering van de gezondheid, met name van de kinderen. Alleen in kolonie III (Willemsoord) waren enige woningen met houten vloeren. Overigens bestonden zij uit rode onverglaasde, brosse en poreuze tegels, die bij regenweer doortrokken waren van vocht en snel afsleten door de klompen. Zo was bv. 
in één der zalen van de gestichten binnen I 2 jaar voor de vierde maal een nieuwe stenen vloer gelegd. Niettemin spraken Staring en Quarles van Ufford in I 846 van „het genot eener goede woning" en andere voordelen, die de kolonisten genoten 72 .

$\mathrm{Bij}$ het Instituut voor den Landbouw te Wateren behoorde een grote boerderij, gebouwd in r 823 en bewoond door de onderdirecteur van de landbouw van de Maatschappij. Dit bedrijf had de Maatschappij in eigen exploitatie. Het bedrijfsgedeelte bevatte stalruimte voor 25 stuks rundvee en 4 paarden, terwijl drie afzonderlijke hokken 400 schapen en enige varkens konden herbergen. Tenslotte behoorden tot de boerderij enkele gereedschaps- en werktuigloodsen en een graanschuur ${ }^{73}$.

De eerder genoemde criticus Wardenburg beoordeelde de boerderij bij het Instituut te Wateren als een ondoelmatig gebouw, dat geen potstal had, maar een vlakke koestal, die men moest uitmesten, en een onvoldoend diepe en luchtige zuivelkelder op het zuiden ${ }^{74}$.

Over de toestand, waarin de gebouwen van de Maatschappij verkeerden, en het uit te voeren onderhoud vindt men tot 1859 slechts weinig in de archiefstukken. In het verslag van de inspectie van de koloniën in I 839 komt de opmerking voor, dat te Groot Wateren een „zeer bouwvallige schuur (is) aangetroffen, welke in dien toestand niet lang meer aan het oogmerk kan voldoen". Dat het onderhoud in het algemeen veel geld vergde en daardoor zeer waarschijnlijk onvoldoende is uitgevoerd, kan men afleiden uit het feit, dat de Commissarissen in de algemene vergadering van de Maatschappij op 2 mei 1863 als één van de gebreken noemden het te dure onderhoud van gebouwen en bruggen, die van een lichte constructie waren, terwijl sommige van slecht materiaal waren gebouwd75.

Tenslotte is in deze paragraaf nog te vermelden, dat de steenbakkerij te Frederiksoord vóór I 846 geheel is opgeheven, omdat hij geen voordeel opleverde. Staring c.s. verwonderden zich hierover en adviseerden tot wederoprichting van de steenfabriek ${ }^{76}$. Hiertoe is men echter niet overgegaan. 


\section{HET PRODUKTIEPLAN EN DE BEDRIJFSVOERING}

\section{AARD VAN HET GRONDGEBRUIK}

$\mathrm{T}^{\mathrm{N}}$ deze inleidende paragraaf zal een algemeen beeld worden geschetst 1 van de inrichting van de landbouw in de vrije koloniën (incl. Wateren). Verscheidene van de te noemen aspecten van landbouw en veeteelt zullen in de volgende onderdelen van dit hoofdstuk meer in details aan de orde komen. Het is de bedoeling hier vooral aandacht te schenken aan de oorspronkelijke opzet van de landbouw en de achtereenvolgende veranderingen, die in de loop van de periode i 8 1 8-1859 zijn voorgesteld c.q. aangebracht. Hoewel ook de vrijboeren grotendeels waren gebonden aan de koloniale voorschriften voor de landbouw, heeft hetgeen in dit hoofdstuk zal worden beschreven in eerste instantie betrekking op de wijze van "verlichte” landbouw, zoals die door de Maatschappij van Weldadigheid werd uitgeoefend op de cultuurgrond, die volledig in eigen exploitatie was.

Dat men zich hier inderdaad bezighield met de voor die tijd "verlichte" landbouw, blijkt uit de oudste jaargangen van het tijdschrift „De Star”, maandblad van de Maatschappij. Van den Bosch publiceerde in dit orgaan verscheidene artikelen op landbouwgebied, waaruit men kan afleiden, dat hij een grondige studie heeft gemaakt van de (hoofdzakelijk buitenlandse) agrarische literatuur van die jaren. Westendorp Boerma noemt in dit verband de geschriften van Thaer, Hermbstädt, Sinclair, Cobbett, Serrurier en Kops, wier denkbeelden over de wetenschappelijke landbouw zijn terug te vinden in de door de Permanente Commissie van de Maatschappij vastgestelde reglementen voor de koloniale landbouw'. Daar Van den Bosch in deze Commissie de enige was, die zich had verdiept in landbouwzaken, mag men veronderstellen, dat de reglementen overwegend, zo niet geheel, van zijn hand afkomstig zijn. Hij verwachtte, dat zijn methode van landbouw, met name de betere vruchtwisseling en mestbereiding, de nadelen van de met landbouwwerkzaamheden onbekende stedelijke kolonisten zou opheffen. 
Van den Bosch was evenwel niet geheel en al een theoreticus op agrarisch gebied. Ofschoon hij als dokterszoon en officier nooit een landbouwbedrijf had geleid, was hij enigermate bekend met de praktijk van de landbouw, zoals bedreven door Chinese kolonisten op Java en door de destijds beroemde Vlaamse landbouwers in het Land van Waas.

Op grond van het voorgaande kan men wel stellen, dat Van den Bosch in zijn koloniën een landbouwsysteem vestigde, dat op revolutionaire wijze verschilde van de toenmalige landbouw op de Drentse en Overijsselse zandgronden.

In het derde hoofdstuk van zijn eerste Verhandeling gaf Van den Bosch een uiteenzetting van zijn plan voor de koloniale landbouw ${ }^{2}$. Hij besefte terdege, dat aan zijn grootscheepse kolonisatie van armen grote moeilijkheden zouden kleven. Uit de gehele historie van de koloniën der Maatschappij van Weldadigheid is duidelijk af te leiden, dat speciaal de mestbehoefte het grote knelpunt is geweest. Het was tevens aanleiding tot een aantal wijzigingen in het landbouwstelsel, zoals hierna zal blijken.

Wanneer een hoeve geheel was ontgonnen, zouden volgens het eerste plan slechts 4 gewassen worden verbouwd op 4 akkers van $\frac{1}{2} \mathrm{mg}$, waarvan één groenbemestingsgewas, n.l. de brem als tweejarige teelt. Deze kan men derhalve als teelt voor de braakjaren beschouwen. De vruchtwisseling dacht hij zich als volgt:

I. aardappelen;

2. boekweit;

3. rogge met brem als onderteelt;

4. brem.

In deze opzet was dus niet voorzien in de aanleg van tijdelijk of blijvend grasland.

Uit het werkelijk toegepaste teeltplan ${ }^{3}$ blijkt echter, dat de brembemesting in de eerste jaren niet is ingevoerd en in plaats daarvan tweejarig klaverland is aangelegd. Bovendien zaaide men een oppervlakte van 300 roeden in met fioringras als min of meer blijvend hooiland (zo lang dit althans voldoende hooi opleverde). Van de totale cultuurgrond per hoeve $\left(3 \frac{1}{2} \mathrm{mg}=2\right.$ I 00 roeden) was 200 roeden in gebruik als tuingrond, 800 roeden voor de akkerbouwgewassen aardappelen en rogge en I 100 roeden voor voedergewassen, waaronder klaver- en grasland van tijdelijke aard4. Blijvend grasland was op de kolonistenhoeven feitelijk niet aanwezig; de verhouding bouwland : tijdelijk grasland (incl. andere voedergewassen) bedroeg $8: 1$. In deze zin kan men wel van gemengde 
bedrijven spreken, maar dan in de betekenis van wisselbouw, ongetwijfeld voor de jaren omstreeks 1820 een modern bedrijfstype.

De Keverberg, die als gouverneur van Oost-Vlaanderen in 1820 een bezoek bracht aan de koloniën te Frederiksoord, gaf in zijn voorwoord tot de Franse vertaling van de tweede verhandeling van Van den Bosch een bijzonder gunstige beoordeling van de landbouwkoloniën. Hij was vol lof over de mestbereiding en wees op het belang van een juiste verhouding tussen de oppervlakte bouwland en kunstweiden. Men hield slechts zoveel vee aan, als nodig was voor de mestvoorziening. Daarbij had men als voordeel de opbrengst aan melk, boter en vlees. Ook noemde hij in het bijzonder de cultuur van fioringras, die in het algemeen nog te weinig bekend was5.

Toen Van den Bosch in 1827 als Commissaris-Generaal naar WestIndië vertrok, was in de vrije koloniën een oppervlakte van I 107 ha heide herschapen in cultuurgrond, verdeeld over 425 kolonistenhoeven. De veestapel bestond uit 455 koeien en een aantal varkens, in gebruik bij de kolonisten, en 1472 schapen en 8 paarden, die werden geëxploiteerd door de Maatschappij6.

$\mathrm{Na}$ een verblijf van $\mathrm{I} \frac{1}{2}$ jaar in West-Indië kwam Van den Bosch in $\mathrm{r} 828$ voor korte tijd naar Nederland terug om van I 829-1 834 als GouverneurGeneraal van Oost-Indië op te treden. Tussen deze bedrijven door ontwierp hij een uitvoerig nieuw reglement op de landbouw voor de koloniën ( 1828 ), dat grotendeels was gegrondvest op het reeds eerder door hem aanbevolen middel van de bremcultuur als groenbemestingsgewas 7 . Uit het Algemeen Verslag over I 828 blijkt, dat het in de bedoeling lag de bremteelt in 1829 geheel in te voeren. Het nieuwe bouwplan resulteerde in een bouwland-graslandverhouding van $3: 1$, waarbij het (tijdelijk) grasland uit klaverweide bestond. De oppervlakte voedergewassen was derhalve ongeveer gehalveerd. Door gelijktijdig gehele stalvoedering in te voeren, "op sommige hoeven althans", hoopte men meer dierlijke mest te verkrijgen en geloofde men, dat de koloniën geheel en al in hun behoeften zouden kunnen voorzien.

In de hiervoor aangegeven bouwland-graslandverhouding is geen rekening gehouden met de losse percelen hooi- en weiland, die de Maatschappij in eigen exploitatie had. Dit is wel het geval geweest bij de eerste kadastrale opneming omstreeks 1830 . Anderzijds zijn hierbij de kunstweiden tot het bouwland gerekend. Op grond van deze gegevens (bijlage 2) komt men voor de vrije koloniën in de gemeenten Vledder, Steenwijkerwold en Weststellingwerf op een totale oppervlakte cultuurgrond van I 168 ha bouwland en 63 ha grasland. In de genoemde betekenis 
resulteert dit in een bouwland-graslandverhouding van niet minder dan I $8,5: \mathrm{I}$. Het was dan ook onvermijdelijk, dat de Maatschappij grote sommen gelds moest blijven uitgeven voor de aankoop van hooi voor de winterperiode.

Van Konijnenburg, destijds directeur van de Maatschappij, constateerde in een brief aan de Permanente Commissie d.d. 22 augustus $183^{8}$, dat aan de landbouw in de vrije koloniën verscheidene tekortkomingen kleefden. Wegens het mestgebrek pleitte hij voor een uitbreiding van de veestapel, hoewel hij eigenlijk de voorkeur gaf aan een grotere mestaanvoer van buiten de koloniën, in het bijzonder voor de Oost- en Westvierdeparten en Willemsoord. Aan het einde van zijn brief constateerde Van Konijnenburg achtereenvolgens: „Eindelijk is het veelvuldig onkruid en gebrekkige grondroering, waarin almede de achterlijkheid van den kolonialen landbouw gelegen is”. En tenslotte: „...de voltalligmaking van den veestapel...zoo dra mogelijk zou behooren te geschieden, teneinde...de winstderving te doen ophouden, welke de onevenredigheid van grond en handen met die van mest veroorzaakt." Hij beriep zich hierbij op de uitspraak van Van den Bosch, volgens welke bij diens laatste vertrek (in I 829 naar Oost-Indië) een aantal van 500 stuks rundvee (in I 83 I : 700 stuks) te weinig aanwezig was. Uit dit schrijven blijkt derhalve zonneklaar, dat de directeur zelf het peil van de landbouw in de koloniën zeer ongunstig beoordeelde, dit in tegenstelling tot de toenmalige officiële publikaties van de Maatschappij, waarin het bestuur de gebreken min of meer verdoezelde.

Uit de beschouwingen van Van Konijnenburg, geschreven bij de oogststaten, die hij jaarlijks moest verzenden aan de Permanente Commissie, valt af te leiden, dat de directeur een tegenstander was van de brembemesting als oplossing voor de moeilijkheden, waarmee hij ten aanzien van de landbouw had te kampen. Gedurende de afwezigheid van Van den Bosch ging Van Konijnenburg rustig voort zijn eigen inzichten in de koloniën toe te passen. De veestapel breidde hij geleidelijk aan uit teneinde te komen tot een „betere verhouding tusschen teelderij en veehouderij, welke laatste nimmer aan zulke groote verliezen blootstaat als wel de eerste"

In de Algemene oogststaat over 1834 gaf de directeur een overzicht van het grondgebruik in de koloniën, dat is weergegeven in de volgende tabel. Hieruit blijkt, dat de verhouding bouwland (incl. bremgrond) grasland (incl. kunstweide) in de koloniën I, II en III in 1834 overeenkwam met $1,1: 1$. Rekent men de gronden te Wateren mede, dan komt men echter tot de verhouding $0,96: 1$, dus ruim $50 \%$ grasland. Dit laatste 
Tabel 5 - AARD VAN HET GRONDGEBRUIK IN 1834

\begin{tabular}{|c|c|c|c|c|c|c|c|}
\hline \multirow[b]{2}{*}{ Kolonie } & \multicolumn{6}{|c|}{ Oppervlakte cultuurgrond in ha } & \multirow[b]{2}{*}{ totaal 3} \\
\hline & $\begin{array}{l}\text { bouw- } \\
\text { land } x\end{array}$ & $\begin{array}{l}\text { brem- } \\
\text { grond } 2\end{array}$ & $\begin{array}{l}\text { kunst- } \\
\text { weide }\end{array}$ & $\begin{array}{l}\text { hooi- } \\
\text { land }\end{array}$ & $\begin{array}{l}\text { tuin- } \\
\text { grond }\end{array}$ & $\begin{array}{l}\text { boekweit- } \\
\text { veen }\end{array}$ & \\
\hline $\mathbf{I}$ & 97,5 & 47,3 & 138,9 & 3,5 & $16,-$ & 4,5 & 307,7 \\
\hline II & 68,4 & 22,4 & 86,7 & - & I 1,5 & 12,6 & 201,6 \\
\hline III & I $33, I$ & 63,1 & 190,7 & - & 19,3 & - & 406,2 \\
\hline Wateren & 35,4 & 6,0 & 27,0 & 74,9 & 0,4 & I 3,5 & I 57,2 \\
\hline $\begin{array}{l}\text { Vrije koloniën } \\
\text { (incl. Wateren) }\end{array}$ & 334,4 & $3^{8,8}$ & 443,3 & 78,4 & 47,2 & 30,6 & $1.072,7$ \\
\hline
\end{tabular}

I Akkerbouwgewassen excl. brem en kunstweide.

21833.

3 In 1833 was in de gewone koloniën 207 ha onbezaaid (braak).

Bron: Algemene Oogststaat over 1834 ; Staat van de te velde staande gewassen 1833 .

cijfer is het meest reëel, daar men in de praktijk ook te Wateren gewonnen hooi vervoerde aan het vee in de gewone koloniën.

Toen Van den Bosch na zijn terugkeer naar Nederland in 1834 bemerkte, dat zijn reglement voor de landbouw van 1828 door Van Konijnenburg slechts zeer ten dele in praktijk was gebracht, kwam het meningsverschil in het bestuur van de Maatschappij in discussie. Wederom werden de ideeën van Van den Bosch door de Permanente Commissie overgenomen, hetgeen resulteerde in het besluit van 23 juli 1836 , dat geheel was gebaseerd op de verhandeling van laatstgenoemde, getiteld "Verhandeling over de inrigting van den landbouw, den arbeid en de administratie"ro.

Deze uitwoering Verhandeling heeft Van den Bosch geschreven in verband met het K.B. van ${ }_{7} 7$ januari ${ }_{1} 836$ no. 84 , dat de subsidiëring van de Maatschappij door de Regering regelde voor de eerstkomende vier jaren. Nadien zou de Maatschappij financieel op eigen benen moeten kunnen staan. Generaal Van den Bosch achtte het om deze reden noodzakelijk de inrichtingen te herzien ten aanzien van de landbouw en de "fabrykinrigtingen". Hij beperkte zich echter voornamelijk tot de landbouw bij gebrek aan volledige bescheiden over de nijverheid. In de gewone koloniën voorzag men door huisnijverheid in de eigen behoeften aan textiel, schoeisel, touw, kruiwagens en huisraad, terwijl alleen garens en linnen naar buiten werden verkocht ${ }^{\mathrm{II}}$. In $183_{3}$ introduceerde 
Van den Bosch de katoenweverij, die sedert I 837 ook voor de markt produceerde.

In de eerste afdeling, getiteld „Over de behoeften”, stelde de Generaal in zijn Verhandeling, dat de landbouw tweeërlei doeleinden moest dienen:

I. voorzien in een deel van de behoeften der bevolking;

2. voldoende voortbrengen aan ruilgoederen om door aankoop van andere artikelen te kunnen voorzien in de overige behoeften.

Onder de behoeften sub I rekende hij de vraag naar rogge, aardappelen, vlas, zuivel, vlees, vet en wol.

In tegenstelling tot de eerdergenoemde uitspraken van I 829 ten gunste van uitbreiding van de veestapel blijkt Van den Bosch in zijn Verhandeling van 1836 voorstander te zijn van inkrimping van de veehouderij en uitbreiding van de bremteelt, hetgeen dus volledig in strijd was met de inzichten van Van Konijnenburg. De Generaal achtte het houden van koeien op zand- en veenachtige gronden zowel moeilijk als schadelijk. Moeilijk in verband met de voederbehoefte in zeer droge of natte jaren; dan was men "niet zeldzaam tot het aankoopen van hooi verpligt" I 2. Schadelijk, omdat men per koe 3/4 à I mg klaverland nodig had voor zomer- en wintervoer, waarbij men 's winters half om half hooi en stro moest kunnen voeren. Volgens Van den Bosch was het voordeliger op deze grond b.v. rogge te verbouwen, als men de benodigde mest op andere wijze kon verkrijgen. Hij concludeerde: „Het is derhalve van belang den veestapel, voor zooveel het houden van koeyen betreft, zoo veel mogelijk te verminderen, althans indien op eene andere wijze in de behoefte van mest, op eene minder kostbare wijze, kan worden voorzien. Zelfs dit zou dan nog wenschelijk zijn, wanneer het zuivel gedeeltelijk moest worden aangekocht, omdat voor een $\mathrm{mg}$ rogge de dubbele hoeveelheid zuivel te bekomen is dan een mg klaver kan opleveren. - De brem is zoodanig een surrogaat."

De tweede afdeling van Van den Bosch' Verhandeling van i $83_{3} 6$ bevat onder de titel „Wijzigingen in het assolement" het door hem aanbevolen vruchtwisselingsplan. Dit komt in zijn algemene vorm neer op $36 \mathrm{mg}$ bouwland tegen $6 \mathrm{mg}$ tijdelijk grasland (klaverland) zonder andere voedergewassen. De bouwland-graslandverhouding bedroeg dus sinds 1836 in de vrije koloniën op de kolonistenhoeven $6: 1$. Vergeleken met het bouwplan volgens het reglement op de landbouw van I 828 (verhouding $3: 1$ ) betekende de wijziging een vermindering van het percentage grasland (klaverland) van 25 tot $14 \%$, wederom bijna een halvering. De veestapel 
werd echter „slechts” verminderd met één derde gedeelte, zodat na de hervormingen relatief meer hooi per roo koeien moest worden aangekocht.

In de derde afdeling „Over het invoeren van de geprojecteerde inrigtingen" beschrijft Van den Bosch de te nemen overgangsmaatregelen tot in details. In het vierde jaar, d.w.z. in I 839, zou het nieuwe produktieplan geheel zijn ingevoerd.

Uit de vierde afdeling "Over de administratieve inrigting van de koloniën" blijkt, dat de Generaal het jaarlijkse tekort voor de vrije koloniën schatte op $f 5322$,- na invoering van zijn hervormingsplan, waarvan hiervoor alleen enkele agrarische aspecten zijn weergegeven.

De slotwoorden van deze Verhandeling, „....kortelijk resumerende de onderscheidene verrigtingen, bij deze aan den Directeur opgedragen...", tonen aan, dat de plannen van Van den Bosch reeds kracht van wet hadden gekregen. Hij was dan ook voornemens begin mei $183^{6} 6$ zelf naar Frederiksoord te gaan "ter regeling van het geen verder gevorderd worden zal, om het oogmerk te bereiken om de Kolonie in staat te stellen in derzelver onderhoud volledig te voorzien." Uit de geschiedenis van de Maatschappij van Weldadigheid is evenwel duidelijk af te leiden, dat Van den Bosch hierin niet is geslaagd.

$\mathrm{Na}$ de invoering van de beschreven hervormingen gaf de Staatscommissie van 26 oktober $184 \mathrm{r}$, ingesteld om de toestand van de Maatschappij te onderzoeken, een over het algemeen ongunstig oordeel over de landbouw in de koloniën ${ }^{13}$. Volgens deze commissie was het landbouwstelsel voor de grond te uitputtend. „Verbazende sommen” moest men uitgeven voor de aankoop van mest en hooi. Men verbouwde te veel granen en aardappelen en te weinig voedergewassen. De commissie beval dan ook een geleidelijke verandering aan in het produktieplan in de richting van meer vee en voedergewassen en uitbreiding van de bebossing van de woeste grond.

Terzelfder tijd pleitte ook de directeur Van Konijnenburg bij de Permanente Commissie weer voor vergroting van de veestapel. Hij raadde het bestuur aan „bij het behoud van de bremcultuur, den veebouw niet geheel uit het oog te verliezen en daarmede vele dierlijke meststoffen, welke, bij afwisseling met de groene bemesting, niet te veronachtzamen is" 14 .

Staring constateerde in 1846 , dat de veestapel te klein was om met de brem het land behoorlijk te bemesten, zodat de aankoop van mest gerechtvaardigd was. Hieruit kan men concluderen, dat ook het laatste plan van Van den Bosch van 1836 niet aan de verwachtingen heeft be- 
antwoord. Staring was evenwel zeer voorzichtig in zijn aanbeveling op dit punt ${ }^{15}$ :

„Vermeerdert men nu de veestapel, dan behoort men óf nog meer veevoeder aan te kopen, of meer land met voedergewassen te betelen, en alzoo granen en aardappelen aan te koopen. Zoo dat 't hier blijkbaar eene fijne berekening is, wat 't goedkoopst te staan komt: mest, veevoer, of menschenvoedsel; eene berekening, welke niet dan na een zeer langwijlig en naauwkeurig onderzoek te maken is, en welke waarschijnlijk meer ten voordeele van den mestaankoop zou uitvallen."

In het licht van deze uitspraak van Staring is het begrijpelijk, dat het bestuur van de Maatschappij geen fundamentele wijzigingen in het produktieplan aanbracht. Dit ondanks het feit, dat men de adviezen van Van den Bosch sinds zijn overlijden op 28 januari 1844 moest missen. Het bestuur volhardde echter ook na zijn dood in de opvattingen van de stichter der koloniën ten aanzien van landbouw en veeteelt.

Deze houding blijkt zeer duidelijk uit de beantwoording (grotendeels weerlegging) van de $\mathrm{I} 2$ aanbevelingen omtrent de landbouw in de gewone koloniën, opgesteld door de Groninger hoogleraar H. C. van Hall als gecommitteerde van de Commissie van Toezicht ter inspectie van de koloniën in $184^{16}$. Van Hall was voorstander van uitbreiding van de veestapel, gedeeltelijk door eigen fokkerij, ter vervanging van de mestaankopen, en van de teelt van meer voedergewassen, zoals knollen, mangelwortelen en ronde of Kaapse duivebonen (deze waren zowel voor dierlijke als menselijke consumptie geschikt). In het Algemeen Verslag over I 848 stelde de Permanente Commissie, dat de ervaring had geleerd, dat vergroting van de veestapel ongunstig was voor de Maatschappij. Zo lang men onvoldoende menselijk voedsel produceerde, wilde men niet denken aan meer veevoederverbouw. Een "veeljarige ondervinding" had bewezen, „dat zoodra aan de behoefte aan zuivel voldaan is, meer vee schadelijk wordt, omdat men goedkooper mest kan aankoopen dan vee onderhouden, en de Maatschappij niet wel kan slagen, om in het groot boter, voor den handel geschikt, te leveren." De behoefte aan melk voor eigen gebruik bleef dus de beperkende factor ten aanzien van de omvang van de rundveestapel, evenals de behoefte aan rogge en aardappelen dit was voor de oppervlakte voedergewassen.

Het Algemeen Verslag over i 849 bevat een algemene beschouwing over de landbouw in de koloniën, waarin het bestuur nog eens uitdrukkelijk te kennen gaf, dat de ondervinding van ruim 20 jaar had aangetoond, dat de vroegere algemene landbouwvoorschriften schadelijk werkten in de koloniën, zodat Generaal Van den Bosch enkele jaren voor zijn over- 
lijden „algemene regelen voor de koloniale cultuur” voorschreef, die in I $85^{\circ}$ nog werden nageleefd en "proefondervindelijk goed" waren. Men voelde dus nog niets voor een nieuwe hervorming van het produktieplan.

In de zomer van 1854 had men blijkbaar toch enigermate gevolg gegeven aan de aanwijzingen van Van Hall. Uit de verdeling van de in de gewone koloniën beteelde oppervlakte over de gewassen (excl. Wateren) blijkt namelijk ${ }^{17}$, dat de bouwland-graslandverhouding, sinds I 836 op $6: \mathrm{I}$ gebracht, inmiddels was veranderd in $\pm 2 \frac{1}{2}: \mathrm{I}$. Het gedeelte kunstweide en grasland bedroeg in 1854 zelfs iets meer dan vóór de hervorming van I 836, t.w. $29 \%$.

Waarschijnlijk is de directeur der koloniën in deze jaren geheel of ten dele weer teruggekeerd tot zijn vroegere principes en heeft hij min of meer op eigen gezag veranderingen in het grondgebruik aangebracht. In zijn toelichtende tekst bij de "Staat van den Rogge-Oogst in $18{ }_{56}$ volgens de tauxatie" verklaarde hij de relatief grote opbrengst te Wateren in een uitvoerig betoog uit $„ .$. het gebruik van schier het dubbel der mest van de andere koloniën en welke, daar en boven, uit veel meer dierlijke mest-stoffen bestaat...”. Van Konijnenburg gaf hier feitelijk in bedekte termen een pleidooi voor meer stalmest en minder brembemesting. In de "Algemeene Oogst-Staat van I 8 56 " sprak hij zich duidelijker uit: de "bloei der koloniën” zou men „met zekerheid” kunnen bevorderen door aanfokkerij van rundvee, waarvoor men een groter percentage grasland behoefde. Het aandeel van het grasland (kunstweide en blijvend grasland) was inmiddels in 1857 in de vrije koloniën excl. Wateren nog iets toegenomen tot $3 \mathrm{I}^{\mathrm{1}} \mathrm{8}$.

In hetzelfde jaar publiceerde Wardenburg, de schrijver van de „Vlugtige waarnemingen” van I 828 , een tweede critisch gestelde brochure, die echter ook enkele reële suggesties voor de toekomst bevatte ${ }^{\mathrm{I}}$. Dit boekje zag het licht in de moeilijkste periode (december r 856 - herfst I 859), die de Maatschappij van Weldadigheid heeft doorgemaakt. Wegens de in financieel opzicht zeer slechte omstandigheden en de op dit punt tussen de Maatschappij en de Regering bestaande meningsverschillen ${ }^{20}$ waren zowel de Commissie van Weldadigheid als de Permanente Commissie afgetreden en was de Maatschappij gedurende deze jaren onder het bestuur gesteld van een Regeringsgecommitteerde. Wardenburg beval o.a. aan de graanbouw op de voorgrond te plaatsen en meer voedergewassen te verbouwen. Inderdaad is het nieuwe bestuur van de Maatschappij, dat na de overgang van de gestichten te Ommerschans en Veenhuizen naar het Rijk in I 859 optrad, in de gewone koloniën tot invoering van deze veranderingen overgaan. 
Terecht beschouwde directeur Van Konijnenburg, die in 1859 tot directeur van de Rijksgestichten te Veenhuizen werd benoemd, het mestprobleem als de grootste fout van de koloniën der Maatschappij van Weldadigheid vóór genoemd jaar. Men had vrijwel alleen bouwland en zeer weinig grasland en vee, waardoor zowel grote hooi- als mestaankopen nodig waren. Voor voldoende stalmest had men z.i. in plaats van 2 en later 1 koe per kolonistenhoeve 3 of 4 koeien nodig gehad. Ondanks de latere wisselbouw met gras en klaver voor groenvoeder en groenbemesting oordeelde Van Konijnenburg, dat het accent te sterk op de rogge en aardappelen had gelegen.

De tuinbouw in de koloniën overziende blijkt, dat elke kolonist aanvankelijk 100 roeden of 14,2 are tuingrond tot zijn beschikking had, waarop hij naar eigen inzicht vroege aardappelen en groenten kon verbouwen. Deze werkzaamheden diende hij te verrichten na de gemeenschappelijke arbeid, die om 16.00 uur eindigde. Reeds in 1828 werd de oppervlakte tuingrond per hoeve meer dan gehalveerd tot 40 roeden, omdat de kolonisten een te groot gedeelte van de mest voor hun tuinen gebruikten, terwijl deze grotendeels bestemd was voor het bouwland, waarvan de oogst in feite eigendom was van de Maatschappij. Volgens het door Van den Bosch in 1836 ingevoerde reglement werden de tuinen op 50 roeden gebracht, waarvan echter de helft naar de gevoelens van de Generaal met brem zou worden beteeld. Met een weinig mest gedurende twee jaren zou men op deze grond zeer goede groenten kunnen verbouwen. In 1837 nam het bestuur de maatregel enige roeden tuingrond af te zonderen, die door de Maatschappij werden beteeld met aardappelen en enkele groentesoorten, waarmee de gezinnen werden voorzien onder aftrek van de bewerkingskosten ${ }^{2 x}$. Deze maatregel kwam hierop neer, dat de kolonisten nog slechts I 8 roeden per jaar in eigen gebruik hadden $^{22}$. Omdat men hierdoor grote ontevredenheid onder de kolonisten opwekte, besloot de Permanente Commissie reeds in 1840 weer tot vergroting van de oppervlakte tuingrond tot 40 roeden per hoeve, die werden afgewisseld met een even grote oppervlakte klaverland ${ }^{23}$.

In 1847 bevorderde de Maatschappij de fruitteelt door aan de kolonisten 400 vruchtboompjes te schenken, die voor een lage prijs waren afgestaan door de Overijsselsche Vereeniging tot Ontwikkeling van Provinciale Welvaart. Het volgende Algemeen Verslag vermeldt opnieuw een dergelijke zending jonge vruchtbomen in 1848 .

De tuinbouw werd in de periode 18 I 8 - 1859 uitsluitend beoefend om in eigen behoeften te voorzien. In 1854 bedroeg de oppervlakte tuingrond in de vrije koloniën zonder Wateren dan ook slechts 23,9 ha, in 
I 857 ongeveer 25 ha, d.i. $2,4 \%$ van de totale oppervlakte cultuurgrond excl. de 17 resp. 19 hoeven van vrijboeren ${ }^{17},{ }^{18}$.

Als bijzondere vorm van agrarisch grondgebruik kan men de bosbouw beschouwen. Over deze bedrijfstak is ten aanzien van de periode 18 I 8 I 859 zeer weinig te zeggen, dit in tegenstelling tot de latere tijdvakken. Recapitulerend hetgeen reeds elders is vermeld, zij herinnerd aan de eerste aankoop van onroerend goed, $\mathrm{nl}$. het huis Westerbeek, waartoe ook enkele bossen behoorden (o.a. het Sterrebosch), alsmede $62 \mathrm{mg}$ bosgrond. Van de laatste oppervlakte is waarschijnlijk $46 \mathrm{mg}$ als bos in stand gebleven. Verder zijn geen bossen aangekocht. Omstreeks I 830 was de oppervlakte bos, in eigendom van de Maatschappij, volgens het kadaster (tabel 2) 49 ha, w.v. 39 ha in de gemeente Vledder. In de gewone koloniën is alleen omstreeks $1832 \pm 6$ ha heide bebost, aansluitend aan het Sterrebosch. De aanvankelijke gedachte van Van den Bosch op elke kolonistenhoeve van $3 \mathrm{mg}$ een oppervlakte van i $\mathrm{mg}$ te bebossen met sparren, is nooit gerealiseerd. Men kan dan ook concluderen, dat de bosbouw tot 1859 van weinig betekenis is geweest. Van Welderen Rengers noemde het ontbreken van bosbouw als één van de oorzaken van de achteruitgang van de Maatschappij tot I 859, zoals deze zijn opgesomd door La Bassecour Caan, de secretaris van het bestuur, dat in I 859 nieuw optrad 24 .

Afzonderlijke vermelding verdient de aard van het grondgebruik te Wateren bij het Instituut voor den Landbouw, waarvan het landbouwbedrijf steeds volledig in eigen beheer bij de Maatschappij is geweest tot de verkoop in I 860 . De aanvankelijk bij dit Instituut behorende I $00 \mathrm{mg}$ heide is gedeeltelijk ontgonnen tot bouwland en kunstweide. In $1826 / 27$ betrof dit volgens het Algemeen Verslag $42 \mathrm{mg}$, in 1828 reeds $65 \mathrm{mg}$ cultuurgrond. Hier begon men ook op vrij grote schaal met bosbouw en bijenhouderij om de kwekelingen daarmee bekend te maken. Het Algemeen Verslag over I 83 I geeft aan, dat in juli van dat jaar vier te Groot Wateren gelegen boerderijen, die de Maatschappij omstreeks 1820 door aankoop had verkregen en tot I $_{3}$ I waren bewoond door gewone kolonisten, met omstreeks 80 ha cultuurgrond bij het landbouwbedrijf van het Instituut werden gevoegd. Volgens het kadaster bestond de cultuurgrond van het Instituut en deze vier boerderijen in 1826 uit 103 ha bouwland, I 4 ha hooiland, I 2 ha weiland en I ha tuingrond. De bouwland-graslandverhouding bedroeg te Wateren dus $4: 1$, hetgeen betekent, dat het percentage blijvend grasland hier aanmerkelijk groter was dan in de gewone koloniën (I 8,5:I).

De uitbreiding van het landbouwbedrijf van het Instituut hing samen 
met het voornemen van de directeur der Maatschappij hier een groot veefokkerijbedrijf te stichten, waarmee men de veestapel in de koloniën met de minst mogelijke kosten zou kunnen vermeerderen. Om dezelfde reden werd bij Wateren het perceel heideveld van 30-40 ha, genaamd Oude Willem, in $1832 / 33$ ontgonnen tot grasland 25 . In 1834 was de bouwland-graslandverhouding van het bedrijf te Wateren (tabel 5) dan ook I:I, d.w.z. $50 \%$ van de cultuurgrond bestond uit blijvend grasland (hooiland). Dit betekent een aanzienlijke verschuiving in de richting van meer grasland. In tegenstelling tot de gewone koloniën met hun akkerbouwbedrijfstype (wisselbouw) was het bedrijf te Wateren een gemengd bedrijf.

In de volgende jaren veranderde het percentage grasland te Wateren slechts weinig. In $\mathrm{I} 842$ bedroeg het $53 \%$, in 1854 precies $50 \%{ }^{26}$. In deze becijfering is het veenboekweitland in het bouwland begrepen, evenals het bremland en braakland $(4,6 \mathrm{ha})$, hoewel dit laatste werd afgeweid. Het was oud, hoog en afgelegen bouwland, dat niet kon worden bemest. Ook in 1857 was de bouwland-graslandverhouding $\mathrm{x}: \mathrm{I}^{27}$.

In de tuin van het Instituut verbouwde men een aantal groentegewassen voor eigen gebruik op een oppervlakte van $0,4^{-} \circ, 5$ ha. Hierin werden ook planten gekweekt, die in de omgeving in het wild groeiden, vooral voedergewassen. Van meer dan 30 grassoorten werd zaad gewonnen om verder te beproeven. In een ander deel van de tuin legde men in 1835 een kwekerij aan van vruchtbomen en andere inheemse bomen om deze te veredelen en de kwekelingen het enten en dergelijke werkzaamheden te leren. Tenslotte zaaide men ook Amerikaanse boomzaden uit, die goed opkwamen, zoals drie soorten eiken, twee acaciasoorten en Platanus occidentalis. De groenteteelt ondervond te Wateren moeilijkheden door de schraalheid van de grond. Daarom voerde men ook in deze tuin de bremteelt in : in 1846 was bijna tweederde gedeelte van de tuin met eenjarige brem bezet, die in de volgende winter of in het voorjaar zou worden ondergespit. Men was "genoegzaam zeker", dat de grond, hoe schraal ook, uiteindelijk "goed vruchtbaar" zou worden ${ }^{28}$. In ${ }^{1} 8_{5} \mathrm{I}$ klaagde de directeur over de konijnenplaag, die de meeste groente deed mislukken. Zo was van de kool bijna niets terechtgekomen; men kende geen middel om de konijnen uit te roeien ${ }^{29}$.

Het is hier tenslotte wellicht een geschikte plaats om in te gaan op de vraag, in hoeverre de "verlichte" landbouw in de koloniën der Maatschappij van Weldadigheid in het beschouwde tijdvak enigerlei voorbeeldfunctie vervulde voor de landbouwbedrijfsvoering op het oude land in de omgeving. Uiteraard is deze vraag achteraf moeilijk te beantwoor- 
den. In de volgende paragraaf zal, voor zover mogelijk, een vergelijking worden getrokken tussen de opbrengsten van de akkerbouwgewassen in de koloniën en daarbuiten. Uit de archiefstukken zijn overigens enkele meningen te destilleren, die men destijds over een eventuele voorbeeldwerking heeft uitgesproken, waarbij echter moet worden betwijfeld, of hier steeds voldoende objectiviteit is betracht.

Zo vermeldt het Algemeen Verslag over I 823/24, dat de invloed van de bedrijfsvoering in de koloniën niet meer beperkt bleef tot de naaste omgeving. Onderdelen van het landbouwsysteem waren overgenomen in o.a. de Alblasserwaard en de Betuwe, aangepast aan de plaatselijke omstandigheden.

In 1826 is onderstaande volzin afgedrukt in het tijdschrift van de Maatschappij ${ }^{30}$ :

„... de landlieden, in den omtrek der Koloniën, verlaten reeds nu in vele opzigten de voorouderlijke, min goede wijze van Landbouw, en nemen langzamerhand de betere manier der Maatschappij van Weldadigheid aan, - dit moge sommigen ongelooflijk toeschijnen, als die meenen, dat zulks onder de boeren na een tijdsverloop van zoo weinige jaren nog geen plaats kan hebben, doch deze herinneren zich niet, dat het belang de sterkste drijfveer bij den mensch is, en dat de landlieden door twee of drie achtereenvolgens gelukkig geslaagde proeven hunner naburen, al spoedig tot navolging worden uitgelokt".

Reeds eerder is opgemerkt, dat de directeur in een brief aan de Permanente Commissie in I 83 r sprak van „de achterlijkheid van den kolonialen landbouw", veroorzaakt door o.a. mesttekort, veel onkruid en gebrekkige grondbewerking. Uit deze brief krijgt men zeker geen hoogstaande indruk van de resultaten van het toegepaste landbouwsysteem.

De subcommissie uit de Commissie van Toezicht, die de koloniën in I 840 inspecteerde, sprak in haar verslag "met gerustheid” als haar oordeel uit, dat „de landbouw dezer Koloniën dien van bijzondere eigenaren niet zelden overtreft”. Waarschijnlijk bedoelde zij met „bijzondere eigenaren" de individuele landbouwers. Deze uitspraak moet men zien in het licht van de in 1836 en volgende jaren ingevoerde landbouwhervorming. Het is niet onmogelijk, dat hierdoor aanvankelijk betere resultaten werden verkregen dan voordien. Zo bevat de Vriend des Vaderlands in de rubriek "Kolonie-Berigten over Julij i 840" de mededeling, dat het buiige weer de rogge buiten de koloniën had doen legeren, terwijl dit in de koloniën niet het geval was, hetgeen werd toegeschreven aan de vruchtwisseling en de diepere grondbewerking. Laatstgenoemd punt kreeg in 1840 blijkbaar meer aandacht dan in 1831 . 
Directeur Van Konijnenburg komt in zijn situatieschets van 1859 , terugziende op de afgelopen periode, tot de slotsom ${ }^{31}$ :

„Daar de landbouw toen reeds algemeen een voorwerp van meerdere wetenschappelijke beoefening was geworden, is het bezwaarlijk uit te maken, welk een gunstigen invloed de landbouw in de koloniën naar buiten gehad heeft; maar vele landbouwers hier in den omtrek zullen toch zulk een' gunstigen invloed op hun bedrijf gaarne erkennen".

De algemeenheid van de wetenschappelijke landbouw moet men stellig in twijfel trekken; deze wijze van landbouwen was destijds beperkt tot een relatief kleine groep adellijke grondeigenaren, die op hun bedrijven experimenteerden met nieuwe methoden. De moeilijkheid van de bepaling van een eventuele invloed van de landbouw in de koloniën op de buitenwereld valt niet te ontkennen. De landbouwliteratuur uit de periode r 8 1 8-1 859 zwijgt hierover. Deskundigen als Jan Kops, Staring en Van Hall, die de koloniën hebben bezocht en beoordeeld, gewaagden in dit tijdsbestek niet van een voorbeeldfunctie. Eerder uitten zij kritiek op de toegepaste methoden, die zij voor verbetering vatbaar achtten. De conclusie lijkt gerechtvaardigd, dat hoogstens van een beperkte invloed sprake kan zijn geweest op de landbouw in de omgeving en op enkele verderaf gelegen bedrijven van hereboeren. Enkele onderdelen van de bedrijfsvoering in de koloniën, zoals het wisselbouwsysteem en de stalvoedering, zullen wellicht elders zijn nagevolgd, van de brembemesting zijn geen andere toepassingen bekend in de Noordelijke Nederlanden. De in de koloniën met de landbouw verkregen financiële resultaten nodigden in het algemeen niet uit tot overneming van gedeelten van het „koloniale” landbouwsysteem. Tevens zal de grote sociale afstand tussen de bewoners van de koloniën en de autochtone bevolking van de omgeving niet bevorderlijk zijn geweest voor het ontstaan van relaties, die leidden tot navolging van onderdelen van de agrarische bedrijfsvoering, door de Maatschappij van Weldadigheid in de koloniën toegepast.

\section{HET BOUWLAND}

Het zal duidelijk zijn, dat de hoogte van de opbrengsten op ontginningsgronden vooral afhankelijk is van de mestvoorziening. Om deze reden wordt eerst aandacht besteed aan dit zo belangrijke onderdeel van de bedrijfsvoering. Eén van de verbouwde gewassen zal eveneens onder $a$ in bespreking komen, n.l. de brem als groenbemestingsgewas. 


\section{a. De mestvoorziening}

Reeds vóór de stichting van de landbouwkoloniën gewaagde Johannes van den Bosch van het mestprobleem, dat hij als één van de moeilijkste zaken beschouwde bij de uitvoering van zijn kolonisatieplan ${ }^{32}$. In zijn eerste verhandeling beschreef hij de verschillende mogelijkheden van mestvoorziening, t.w.:

I. aankoop van stalmest;

2. rundveehouderij;

3. schapen- en varkenshouderij;

4. benutting van faecaliën;

5. teelt van brem als groenbemestingsgewas;

6. gebruik van bagger, heideplaggen, as en andere stoffen.

Bij de aankoop van stalmest vormde het transport een bezwaar. Het vervoer langs de weg zou per wagenvracht $f \circ, 50$ kosten; Van den Bosch gaf de voorkeur aan transport per schip door de hiertoe aan te leggen vaarten.

De mestproduktie van het rundvee stelde hij op ongeveer $\mathrm{I} \frac{1}{2}$ voer mest per 3 stuks rundvee per week. De mest van 3 koeien achtte hij voldoende voor $2 \mathrm{mg}$ bouwland (mestbehoefte per $\mathrm{mg} 35$ voer per jaar). Om deze 3 koeien te kunnen voeden was echter $\pm 2 \frac{1}{4} \mathrm{mg}$ grasland nodig. Bij deze becijfering nam de generaal niet in aanmerking, dat ook het grasland mest nodig zou hebben. Hij wees de rundveehouderij als mestbron echter af als strijdig met het oogmerk zo veel mogelijk mensen te laten leven op zo weinig mogelijk grond. Dit standpunt ten aanzien van de veeteelt kan men m.i. als de grootste fout beschouwen, die aan het kolonisatieplan kleefde. Een fout, die voor een belangrijk gedeelte de oorzaak was van de financiële moeilijkheden, die de Maatschappij van Weldadigheid korte tijd na haar oprichting reeds het hoofd moest bieden.

Van den Bosch voelde meer voor het houden van schapen en varkens, die men kon laten weiden op de heide resp. in eikenbossen.

Vervolgens gaf hij in zijn verhandeling een uitvoerig betoog over dierlijke mest in het algemeen, de samenstelling van de verschillende soorten mest en planten en over de vorming van humus, genoemd „aarde uit het planten- en dierenrijk" of "modder". In deze beschouwing volgde Van den Bosch de „Boerengoudmijn” van Serrurier, die zich voornamelijk baseerde op de theorieën van Albrecht Thaer ${ }^{33}$. Onder andere noemde Van den Bosch de zienswijze, dat koolstof in de aarde aanwezig moet zijn, opdat de planten vruchten zullen voortbrengen. 
De eerste plaats als mestproducent kende hij toe aan de mens, wiens uitwerpselen het "allervoedzaamst" waren. Dit bleek uit het gebruik in de Zuidelijke Nederlanden, in China en ook in de Groninger veenkoloniën (straatvuil vermengd met de z.g. sekreetmest). Een „bezet” huisgezin van 6 personen leverde naar de mening van Van den Bosch voldoende mest op voor I $\mathrm{mg}$ land. Men moest de uitwerpselen verzamelen in stenen bakken en vermengen met kalk, as en plaggen. Elk gezin zou ter aanvulling van de mest twee of drie varkens kunnen mesten of enige schapen houden. De mestproduktie van 6 schapen stelde hij gelijk met die van 3 varkens resp. I koe. In 4 maanden konden 3 varkens $\pm \mathcal{I}$ voer mest opleveren, hetgeen in kracht gelijk stond met \pm I I voer koemest.

De teelt van brem (Spartium scoparium) vond Van den Bosch zeer geschikt „om gedeeltelijk de plaats van mest te vervullen”. Hij haalde in dit verband het geschrift van Thys aan en beval dan ook een vruchtwisseling aan met tweejarige brem als groenbemesting. Dan was slechts de helft van de normale hoeveelheid dierlijke of menselijke mest nodig.

Thys, kanunnik van de abdij van Tongerloo, vermeldde in zijn memorie dat de bremteelt wel voorkwam bij verscheidene dorpen in Brabant, maar niet in de Meierij van Den Bosch. Hij beval de bremcultuur ook aan voor de ontginningen in dit gebied en baseerde zich in dit opzicht vrijwel uitsluitend op een memorie van de Vlaming F. de Coster, die hij uitvoerig citeerde. Brem kon goede diensten bewijzen bij de ontginning van woeste grond en het vruchtbaar houden (bemesting), leverde tevens hout met enige waarde en kon tenslotte weide verschaffen, wanneer men wat klaver in de brem zaaide.

Thys' conclusie luidde: „dat eenen Akkerman, vage gronden willende opbreéken, Brem zal moeten zaeyen, om dien grond beter te maeken, welken door 't overige mest, dat hy zal hebben, geholpen, eyndelyk met voordeel den Land-bouw op zulken grond zal voortzetten" ${ }^{34}$.

Als andere meststoffen noemde Van den Bosch ten slotte nog hoorns, spaanders, verrotte vis, gestampte beenderen, uitgeperste lijn- of raapkoeken en groenbemesting met rapen (Noord-Holland). Raapkoeken achtte Van den Bosch echter te duur.

Hoe vond nu de feitelijke mestvoorziening in de eerste bestaansjaren van de koloniën plaats? Uit de tweede verhandeling van de stichter blijkt ${ }^{35}$ dat in 1820 elk kolonistengezin de beschikking had over twee koeien. Door volledige stalvoedering, ook des zomers, werd alle koemest verzameld. Volgens zijn eerdergenoemde normen was deze voldoende voor I $\frac{1}{3}-2 \mathrm{mg}$ cultuurgrond. Met de menselijke uitwerpselen zou men dus de 
behoefte van $2 \frac{1}{3}-3 \mathrm{mg}$ kunnen dekken. Bovendien kwam ook reeds groenbemesting voor, terwijl maatregelen waren genomen tot aanschaffing van kudden wolschapen. Bij elke woning was een reservoir gemaakt voor beer, keukenafval, waswater etc., dus een soort gierkeldertje. Op één en ander baseerde Van den Bosch zijn optimistische uitspraak: „Men kon hierdoor rekenen op goede resultaten". Elders in zijn tweede verhandeling stelde hij de norm, dat elk tweetal koeien per jaar aan met plaggen gemengde mest 75-100 voer opleverde 36 . Dit is dus aanzienlijk meer dan volgens zijn eerste geschrift ( 52 voer per jaar per twee koeien). De gierput verschafte nog 20-30 voer vloeibare mest of gier per jaar, d.i. te zamen 95-1 30 voer. In verband gebracht met de eerder door Van den Bosch geraamde behoefte van 35 voer per mg per jaar concludeerde hij nogmaals, dat de kolonisten voldoende mest produceerden voor hun hoeven van $3 \frac{\mathrm{I}}{2} \mathrm{mg}$. Aardappel-, klaver- en fiorinland kreeg alleen gier.

Von Grouner's reisbeschrijving bevat een groot aantal gegevens over de mestvoorziening in het begin van de jaren twintig, waardoor een vollediger beeld kan worden geschetst van de feitelijke gang van zaken. Ten behoeve van de ontginning verkreeg men de benodigde mest op de volgende wijzen ${ }^{37}$ :

I. aankoop uit Holland, later alleen uit de Cavaleriekazerne te Zwolle;

2. indirect door hooiaankoop voor het vee der kolonisten;

3. van de eigen trekveestapel (paarden en ossen, nauwkeurig beperkt tot de behoefte) en vooral de schapenstapel, die zowel mest leverde als wol voor de bevolking. Het waren heideschapen van de gewoonste soort. De edeler rassen waren ongeschikt voor de heide. De kudden bestonden gewoonlijk uit 300 stuks, die overdag werden geweid en 's nachts ondergebracht in op de heide gebouwde schaapskooien van eenvoudige makelij.

$\mathrm{Na}$ de ontginningsperiode waren de mestroorschriften van kracht, waarover Von Grouner het volgende opmerkte ${ }^{38}$. Elke kolonist moest per jaar niet minder dan 300 voer mest van 1000 pond maken en hiermede zijn gehele land bemesten. Dit stond gelijk aan minimaal 25 voer per maand; beter nog was 30 voer. Volgens Beierse maatstaven kon men van één koe echter per jaar niet meer dan 20-25 voer verwachten. In Frederiksoord rekende men evenwel op het zeven- of achtvoudige. Al is dit laatste wellicht enigszins overdreven, het is toch wel duidelijk, dat de aan de kolonisten opgelegde verplichting overeenkwam met ongeveer het zeswoudige van zowel de mestproduktie van 2 koeien in Beieren als de in eerste aanleg door Van den Bosch gehanteerde norm van 26 voer per koe per jaar. Het is wel als vaststaand aan te nemen, dat de door de 
Maatschappij voorgeschreven produktieomvang van de mest door de kolonisten niet werd bereikt.

Von Grouner noemde vervolgens zes algemene mestbronnen voor de koloniën :

I. de wegen, die tweemaal per jaar werden bijgewerkt;

2. de kanalen, die vaker werden geschoond;

3. de plaggenbruggen voor de kolonistenwoningen, die om de drie jaar werden vernieuwd;

4. de schapendriften, die ook tweemaal per jaar werden geschoond;

5. de stalmestbron, de belangrijkste voor de koloniën;

6. de turf.

Over de stalmestbereiding vermeldde Von Grouner nog vele bijzonderheden. Het graanstro gebruikte men voor veevoer en dakbedekking. Heideplaggen dienden als strooisel voor de koeien. De kolonisten staken de plaggen met de spade voor rekening van de Maatschappij in akkoordloon. Het arbeidsloon moesten zij bij aankoop van plaggen aan de Maatschappij terugbetalen. Om in de behoefte aan strooisel te kunnen voorzien was per kolonist nog een oppervlakte van $3 \frac{\mathrm{l}}{2} \mathrm{mg}$ heide nodig. Dit vond Van den Bosch te veel. Hij zocht daarom andere bronnen van strooisel. Turf achtte hij hiervoor onbruikbaar; men kon door vermenging van turf en gebrande kalk wel een meststof maken. Van den Bosch gaf de voorkeur aan het afplaggen van tweejarig klaver- en raaigrasland ter dikte van één duim. Op deze wijze konden de kolonisten ruimschoots strooisel verkrijgen. De generaal was van oordeel, dat twee voer mest van klaver- en raaigrasplaggen evenveel waard was als drie voer van heideplaggen. Het boekweitstro werd in kleine hoeveelheden als strooisel gebruikt.

Volgens de voorschriften moest men 's morgens en 's avonds strooien; tevens werd dan de voorste en achterste helft van de mest onder de koeien verwisseld. Per dag verbruikte men $\frac{1}{2}$ voer strooisel. Eenmaal per week werd de stal uitgemest in de gierbak. Deze was rond, 3-4 voet diep en aan de zijkant en onderin bekleed met turf of heideplaggen. De doorsnede bedroeg $\mathrm{I} 2$ voet. Het geheel zou waterdicht zijn, "maar is het niet", aldus Von Grouner ${ }^{39}$. De stal stond door een afvoerkanaal in verbinding met de gierbak, in de hoeven van het oudste type was dit ook het geval met het sekreet. In de nieuwere woningen werden de menselijke uitwerpselen in een afzonderlijke ton gedeponeerd. De beerton werd eenmaal per twee dagen geledigd in de gierbak, waarin ook de haardas en het huisvuil werden verzameld. Eens in de vier weken moest men de gierbak ledigen. 
De mest werd dan achter de woning laagsgewijs opgestapeld, zodat elke laag van verschillende ouderdom was. Men maakte de mesthoop 3-5 voet hoog en bedekte hem met een laag heideplaggen om de warmte vast te houden en de regen te weren. Nadat de hoop I-3 maanden had gestaan, werd het plaggendek onderin de lege gierbak gelegd en de mest door middel van een kipkar in hopen op het land gebracht. Deze hopen bestrooide men laagsgewijs met gebrande kalk, per voer mest 3/5 tot I kub. voet kalk. Na nog 2-4 weken te hebben gestaan, werd de mest verspreid over het land en ondergespit of -geploegd.

Deze wijze van mestbereiding verzekerde de welstand van de koloniën, aldus Von Grouner, die ook vermeldde, dat het een Chinese methode was, die Van den Bosch in Indië had leren kennen ${ }^{40}$.

Uit de beschreven werkwijze blijkt, dat de stal van het potstaltype was, hoewel de mest er niet langer dan een week bleef liggen. Het komt als omslachtig voor, dat de mest uit de stal eerst in de gierbak of mestbak werd gedeponeerd en vandaar weer eenmaal per vier weken op een hoop werd gezet. Men had de tussenfase zonder nadeel kunnen overslaan. Het afdekken van de mesthopen met heideplaggen was zeker nuttig om verlies van organische stof en stikstof tegen te gaan. De directe afvoer van gier, voor zover niet door het strooisel opgezogen, naar de gierbak was eveneens voordelig, hoewel men beter de mest zelf niet in de gierbak had kunnen deponeren, maar afzonderlijk aan hopen had moeten zetten. Een gescheiden bewaring van vaste en vloeibare uitwerpselen beschouwt men tegenwoordig wel als de beste methode. Het is zeker, dat veel verlies optreedt, wanneer men mesthoopjes lange tijd op het land laat staan. De periode van 2-4 weken, hierboven genoemd, was veel te lang en dus weinig zinvol.

Interessant is nog, dat Van den Bosch een methode van mestonderzoek invoerde om te bepalen, of de mest voldoende verteerd was, als hij op het land werd gebracht. Daartoe nam men van de mesthoop een monster, waarvan twee bepaalde hoeveelheden in gedestilleerd water of regenwater werden geroerd. Het eerste proefje liet men $36-48$ uur staan, waarna het werd gefiltreerd en ingedampt tot honingdikte. Het ingedampte extract (of humus) gaf, al naar de hoeveelheid, aan, of de mest al dan niet voldoende was vergaan. Het tweede proefje werd met lakmoespapier onderzocht op vrij zuur. De bepaling van de benodigde kalktoevoeging tot neutrale reactie leverde de hoeveelheid kalk op, die met een voer mest moest worden vermengd. Als de mest te zuur bleek te zijn, voegde men extra kalk toe en liet de hoop nog enige tijd staan voor afbraak der zuren en verdere humificatie. Generaal Van den Bosch hanteer- 
de als norm, dat de mest vóór het gebruik op het land minstens $2 \%$ extractvloeistof moest opleveren.

Omtrent het gebruik van turf als meststof vermeldde Von Grouner twee werkwijzen ${ }^{41}$. De eerste heeft betrekking op de ontginning van droge zandgronden. Hierop spreidde men gedroogde turf uit, stelde deze bloot aan de vorst en egde de turf in het voorjaar fijn. Het vochthoudende vermogen van de grond werd door deze methode vergroot. De tweede werkwijze bestond uit de verbranding van opgestapelde turf, waarna de as voor bemesting werd gebruikt. Om de verbranding onafhankelijk van het weer te kunnen uitvoeren, paste men na enkele jaren een Engelse uitvinding toe in de vorm van een ijzeren raamwerk, waaromheen de turfhoop werd gebouwd. In de luchtgang stak men droog materiaal aan, waardoor de turf geleidelijk verbrandde door gloeien.

Het is opvallend, dat Von Grouner geen melding maakte van enigerlei vorm van groenbemesting in tegenstelling tot andere schrijvers ${ }^{42}$. Zoals later zal blijken, dateerde de brembemesting niet van de eerste bestaansjaren van de koloniën, ofschoon Van den Bosch wel het plan koesterde de bremteelt van den beginne af in te voeren.

In de eerste Algemene Verslagen van de Maatschappij liet Johannes van den Bosch ook over de mestroorziening optimistische geluiden horen. Zo heet het in het Verslag over $1822 / 23$ bij de beschrijving van kolonie I, dat men "de middelen verkregen (had) om zooveel mest te maken, als de grond slechts verdragen kan." In hetzelfde verslag is ook de opmerking gemaakt, dat slechts aanvankelijk in enige koloniën een zeer matige aanvoer van vreemde mest nodig was voor het eerste jaar.

Prof. Jan Kops, die in 1823 de koloniën bezocht, vermeldde in zijn landbouwverslag ${ }^{43}$, dat men het voorbeeld van enige omliggende streken volgde door tweejarig klaver- en raaigrasland af te plaggen, deze plaggen op de mesthoop te brengen en met andere stoffen om te zetten. Hij spreekt in dit verband van "zodenmest". De vondst van mergel in kolonie III (Willemsoord) noemde Kops een voortreffelijke ontdekking. De mergelbemesting zou de Maatschappij in staat stellen met goed gevolg vlas te verbouwen; een gewas, dat op de vruchtbaarste klei thuishoorde 44 .

In het Algemeen Verslag over I 826/27 wordt voor de eerste maal melding gemaakt van de invoering van de bremteelt voor groenbemesting in de gewone koloniën. Per hoeve was in de herfst van I 826 en het voorjaar van r 827 op een oppervlakte van 400 roeden (ongeveer 2/9 gedeelte van de hoeven) brem ingezaaid onder rogge. Eindelijk had men hiervoor voldoende zaad van goede kwaliteit ontvangen; dit was voordien moeilijk te verkrijgen geweest. Sinds Van den Bosch zijn eerste verhandeling had 
geschreven (1 8 I 8 ) en daarin de bremteelt had aanbevolen, waren in de Zuidelijke Nederlanden, vooral in de provincie Antwerpen, goed geslaagde proeven genomen. Eveneens in $1826 / 27$ is te Wateren een proef uitgevoerd met de teelt van rogge en aardappelen na ondergespitte brem, die zeer voldoende resultaten had. De aardappelen leverden na brem $20 \%$ meer op dan na een gewone bemesting met stalmest 45 . Te Wateren moet dus reeds in 1825 of $\mathrm{I} 824$ een begin zijn gemaakt met de uitzaai van brem, zij het dan bij wijze van proefneming.

In 1828 oogstte men in de vrije koloniën voor de eerste maal, op bijna $2 \mathrm{mg}$ land verdeeld over 8 percelen, aardappelen na een brembemesting en een geringe tot halve gewone bemesting. De gemiddelde opbrengst per mg bedroeg bij deze proefneming niet minder dan $222 \mathrm{mud}$, terwijl na gewone bemesting in dit voor de landbouw gunstige jaar I 35 mud per mg werd geoogst46. In dit geval dus een voordelig resultaat met de brembemesting van bijna $65 \%$ meer dan bij gewone bemesting.

Uit een beschrijving van de bremteelt47 blijkt, dat de Maatschappij de verbouw in $1826 / 27$ beschouwde als een proef op grote schaal, in navolgingvan „sommige Vlaamsche, maarvooral Brabandsche Landbouwers”. Bij de roggeoogst was de brem 3-6 palm hoog, zodat de toppen van de bremplanten dan moesten worden afgesneden. Deze liepen later weer sterk uit. Hieruit kan men afleiden, dat de bremteelt een geringere opbrengst van roggestro (veevoeder) ten gevolge had. De roggestoppels waren langer dan normaal het geval was zonder brem. De bemestingskracht van de brem meende men in 1827 gelijk te kunnen stellen met een ondergespitte "dubbele schoof" spurrie of boekweit. De in de herfst ondergespitte z.g. stoppelbrem zou met een kleine gewone bemesting ongetwijfeld een goede oogst geven. Een ander gedeelte werd eerst in het volgende voorjaar of in de zomer ondergespit als z.g. jarige brem. Hiervoor is reeds geconstateerd, dat de eerste aardappeloogst na uitsluitend brem als bemesting bepaald gunstig was.

In Vlaanderen was de bremteelt reeds toegepast sinds de Middeleeuwen. Het was de plant "die het ontstaan van de landbouw mogelijk maakte in de armste zandstreken van ons land", constateert de Belgische landbouwhistoricus Lindemans ${ }^{48}$. Tot in de rgde eeuw teelden de Vlamingen de brem, gezaaid in de rogge, als voeder- en bemestingsgewas. In het Land van Waas was de brem drie- of vierjarig en verbouwde men boekweit of aardappelen als nagewas.

In het jaar 1828 verscheen de eerdergenoemde brochure van de hand van een anonieme schrijver. Ofschoon men de betrouwbaarheid van dit geschrift in twijfel kan trekken, toont het in ieder geval aan, dat bij het 
tienjarig bestaan van de landbouwkoloniën een mestprobleem aanwezig was, dat destijds waarschijnlijk het belangrijkste onderwerp van discussie vormde ten aanzien van het landbouwstelsel te Frederiksoord en omgeving. De eerste twintig bladzijden van de brochure zijn gewijd aan een kritische beschouwing over de naar de mening van de schrijver onvoldoende bemesting. In het algemeen stelde hij: "Van den Bosch had geen de minste kennis van de hoeveelheid meststoffen, die hij nodig had, toen hij zijn Verhandeling schreef." De norm van de mest van één koe voor één morgen bouwland, gehanteerd door Van den Bosch, noemde hij veel te laag. In Drenthe en Overijssel hadden de boeren z.i. de mest van één koe nodig voor één mudde bouwland, d.i. ruim driemaal zo veel. Ook de hoeveelheid mest, die de generaal berekende uit de menselijke uitwerpselen, was volgens de anonieme schrijver onjuist. Op grond van enkele factoren kwam hij per gezin op een hoeveelheid menselijke mest van 6 voer in plaats van de 25 voer van Van den Bosch. Hij concludeerde, dat per gezin te weinig mest beschikbaar was voor $\mathrm{I}_{4}^{1} \mathrm{mg}$ land, terwijl Van den Bosch voldoende mest aanwezig achtte voor $3 \frac{\mathrm{I}}{2} \mathrm{mg}$ ! Bovendien, zo bemerkte de anonieme criticus op, is op nieuw ontgonnen heidegrond in het derde of vierde jaar behoefte aan een dubbele bemesting. In Frederiksoord was volgens hem dan ook de roggeopbrengst ongeveer I/3 van de normale oogst in Drenthe ondanks de aankoop door de Maatschappij van duizenden raapkoeken voor de bemesting van het aardappelland.

Uitvoerig stond de schrijver vervolgens stil bij de wijze van mestbereiding 49 . Het reglement van i 820 schreef voor ${ }^{50}$, dat de mest moest worden verkregen door vermenging van \pm I 50 voer plaggen, in een hoop gezet, met ro voer straatvuil, 5 voer paardenmest, ro schepels ongebluste kalk. Na broeien diende men nog toe te voegen 500 pond beendermeel, i 50 pond roet en 5 schepels ongebluste kalk. Dit was de wijze van mestbereiding in de ontginningsjaren. Naar de mening van deze criticus was hierbij de verhouding tussen dierlijke en plantaardige stoffen te sterk in het nadeel van de dierlijke mest. Men kreeg wel vermeerdering, maar geen verbetering.

Sinds 1822 was een andere methode ingevoerd5r. Bij gebrek aan plaggen moest worden vermengd : 25 voer verse paardenmest en 25 voer zuivere koemest met 30 voer veen, 30 voer leemachtig zand en 30 schepels kalk per $\mathrm{I} \frac{\mathrm{r}}{2} \mathrm{mg}$. Volgens anonymus bevatte dit mengsel te veel veen, waardoor het te zuur was voor een goede gisting en veel van de mestwaarde verloren ging. Meer kalk en as waren z.i. nodig.

Het raapkoekenmeel, waaraan de Maatschappij vele duizenden guldens 
besteedde, was, ondanks de veelvuldigde toepassing in Brabant, "meer tot opwekkende dan tot voedende mestspeciën te rekenen." Het had niet de minste uitwerking zonder koemest. De schrijver oordeelde, dat proeven beter waren geweest dan een gebruik op grote schaal. In Frederiksoord werd verder nog bemest met olie en oliedroesem: een mengsel van as, kalk en olie strooide men als proef over vlas. De auteur stelde terecht, dat kalk en olie samen kalkzeep vormen, die onoplosbaar is.

De reacties van het bestuur der Maatschappij op de anonieme brochure lieten niet lang op zich wachten. In het tijdschrift De Vriend des Vaderlands werd reeds omstreeks mei i 828 een artikeltje opgenomen, dat zou zijn geschreven door de kolonist Klaas Visser, die bijna to jaar in Frederiksoord en Wilhelminaoord had gewoond. Hij beschuldigde de schrijver van laster en leugens en vereenzelvigde hem met de ontslagen voormalige adjunct-directeur Wardenburg van kolonie vir. Deze was na overplaatsingen naar Veenhuizen en Ommerschans tenslotte wegens zijn gedragingen ontslagen. Men kan zich afvragen, hoe een eenvoudige kolonist deze en andere persoonlijke bijzonderheden kon weten. De eerste reactie op de Vlugtige waarnemingen lijkt m.i. op een geensceneerde zaak, zodat men ook de juistheid van de tweede reactie wel mag betwijfelen.

Het tweede verweerschrift5 ${ }^{52}$ geschreven door de Permanente Commissie, bevestigt inderdaad, dat de criticus een voormalige adjunctdirecteur van de laagste klasse was. In het algemeen weerlegde het bestuur alle kritiek van Wardenburg. De per hoeve geproduceerde mest was weliswaar niet voldoende voor de eerste bemesting bij de ontginning, maar wel voor de instandhouding van de bodemvruchtbaarheid, die zelfs regelmatig toenam. Over de bemesting van vlas met een mengsel van olie en as merkte de Permanente Commissie op, dat deze de beste uitwerking had. Feitelijk vormden de beide bestanddelen wel kalkzeep, maar met water zou dan zeepsop ontstaan, dat volgens Serrurier een grote groeikracht bezat. Omdat houtas (beter dan turfas) moeilijk was te verkrijgen, was men met deze bemesting opgehouden. Bovendien had raapkoekenmeel dezelfde goede uitwerking gegeven.

De berekening door Wardenburg van de hoeveelheid beschikbare mest per mg kon in de ogen van het bestuur in het geheel geen goedkeuring verdienen. Voor de gewone koloniën kwam de becijfering van de Permanente Commissie tot de mest van 1088 (omgerekende) koeien, ongerekend de varkensmest, haardas, het zeepwater en groentenafval. De oppervlakte ontginningsgrond bedroeg i $100 \mathrm{mg}$. Er was dus I koemest per mg beschikbaar, aldus de Permanente Commissie. 
Ondanks de hierboven weergegeven verzekering van de zijde der Maatschappij, dat de mestvoorziening zonder aankoop voldoende was, ging men op korte termijn over tot volledige invoering van de bremteelt. In 1829 bedroeg de oppervlakte aardappelen, geteeld na een brembemesting en gedeeltelijk een halve gewone bemesting, ruim $18 \mathrm{mg}$ met een gemiddelde opbrengst van $70 \mathrm{mud}$ per $\mathrm{mg}$, terwijl de opbrengst bij gewone bemesting $60 \mathrm{mud}$ per $\mathrm{mg}$ bedroeg. In beide gevallen was dit ongeveer $2 / 3$ gedeelte van een normale oogst door de vele regens ${ }^{53}$. In hetzelfde jaar stelde Van den Bosch een nieuwe instructie op, feitelijk alleen gebaseerd op de resultaten van de proeven van 1828 , waardoor met ingang van I 829 de bremcultuur geheel werd voorgeschreven als onderdeel van een gewijzigd vruchtwisselingsstelsel. Het Algemeen Verslag over I 828 maakt hiervan reeds melding en zet uiteen, dat alle hoeven werden verdeeld in 8 percelen van $25^{\circ}$ roeden en een tuinperceel van 100 roeden. Ieder jaar zou men op 3 percelen rogge verbouwen, waarvan 2 percelen met ondergezaaide brem. $\mathrm{Na}$ de roggeoogst volgde op het ene perceel na de stoppelbrem een aardappelgewas, terwijl de brem op het andere perceel nog één vol jaar zou blijven staan. Men geloofde, dat de koloniën door deze maatregelen geheel en al in hun onderhoud zouden kunnen voorzien. Dit was zeker wel een gewaagde verwachting; zij was slechts gebaseerd op enkele proeven. Het ware beter geweest voorlopig proefnemingen op grotere schaal uit te voeren. Waarschijnlijk dwongen echter ook in dit geval de ongunstige financiële omstandigheden tot deze reorganisatie "op hoop van zegen”.

Einde 1829 bestond de oppervlakte cultuurgrond in de vrije koloniën (roog ha) voor niet minder dan 2 1 3 ha of ruim $20 \%$ uit bremland. Het Algemeen Verslag over dit jaar zegt tevens, dat men door de lange winter van 1829 op I 830 in het voorjaar, wegens tijdgebrek, de eenjarige brem geheel moest laten staan tot de herfst van $183^{\circ}$ (roggezaai) of de lente van r 83 I (aardappelen). Ook de brem had bijzonder geleden door de strenge winter.

In het najaar van 1829 is de kolonisten opnieuw aanbevolen de zuivere koemest te vermengen met heide- of veenplaggen, slootaarde en andere plantaardige stoffen om de hoeveelheid te vermeerderen. Bij een inventarisatie van de verzamelde mest in begin december bleek deze aanbeveling goede resultaten te hebben: de mestvoorraad was groter dan voorheen. Ook moesten de kolonisten hun haardas droog bewaren en in februari/maart over het klaverland strooien in navolging van de Vlamingen.

Ondanks deze maatregel moest de Maatschappij in april $183^{\circ}$ weer een 
partij Amsterdams straatvuil aankopen. De brem, die op laag, veenachtig land was gezaaid, was mislukt. Het bleek steeds meer, dat deze plant onder graan (vooral rogge) moest worden gezaaid om goed te slagen 54 . Het Algemeen Verslag over 1830 deelt mede, dat in dit jaar weinig nut is ondervonden van de brembemesting, hetgeen men toeschreef aan de vele regens in de voorafgaande jaren en de strenge winter van $1829 / 30$. De groei van de brem was minder dan in "gewone tijden". Deze vergelijking lijkt erg moeilijk uitvoerbaar, daar men de brem nog slechts enkele jaren had geteeld. Hoe dit ook zij, het begin van de bremteelt op grote schaal is blijkbaar geen groot succes geweest.

In tegenstelling tot het vorige jaarverslag vermeldt het verslag over 1 $83^{\circ}$, dat bij een inspectie van de hoeven was gebleken, dat "de mestmakerij zeer veel te wenschen overig liet". De bestaande mestbepalingen werden dan ook vernieuwd en verscherpt. De ambtenaren moesten deze en andere zaken wekelijks en maandelijks opnemen. De nieuwe regels waren aanvankelijk „niet zonder moeite ten uitvoer gelegd", maar de tekortkomingen van de kolonisten waren niet aanzienlijk en verminderden in aantal.

Ook te Wateren had men nog geen afdoende oordeel over de bremteelt. Hier was rogge gezaaid na eenjarige en na tweejarige brem met een halve gewone bemesting. In het laatstgenoemde geval stond de rogge het beste.

Vanaf het jaar $\mathrm{I}_{3} \mathrm{I}$ is een duidelijker inzicht te verkrijgen in de ontwikkeling van de landbouw in de koloniën uit de reeds eerder genoemde oogststaten met toelichtende tekst, opgesteld door de directeur Van Konijnenburg. Elders 55 zijn hieruit de conclusies getrokken, dat laatstgenoemde in het algemeen een tegenstander is geweest van het wondermiddel van de brembemesting en meer gevoelde voor een uitbreiding van de veestapel. Ook is gewezen op het feit, dat het bestuur van de Maatschappij in het meningsverschil tussen Van den Bosch en Van Konijnenburg de zijde van de generaal koos en zijn ideeën in praktijk heeft gebracht. In deze paragraaf zullen nog enkele bijzonderheden uit de oogststaten naar voren komen, die speciaal betrekking hebben op het probleem van de mestvoorziening.

De sceptische opvattingen van de directeur ten aanzien van de bremteelt blijken uit zijn opmerkingen: $„ \ldots$ oogst met en zonder brem volkomen gelijk" ( 183 I) en „De brem op leemachtigen grond minder voort willende, zoo was hier tot dit aardappelgewas genoegzaam geen brem voorhanden" ( 1832 , Willemsoord) ${ }^{56}$. Het Algemeen Verslag over I 832 toont dan ook aan, dat in de koloniën I, II en III op slechts 2 I van de I I 2 
ha aardappelland brembemesting was toegepast, waarvan zeer overwegend met bovendien een volle gewone bemesting. Hierdoor verkreeg men een 26-28\% grotere opbrengst dan bij uitsluitend gewone bemesting. De brem had de vruchtbaarheid van de grond dus vermeerderd, hoewel men ook rekening moest houden met de kosten van het zaaien van de brem en het moeilijke onderspitten, aldus het verslag. Hieraan kan men nog toevoegen de geringere opbrengst aan roggestro en het missen van één geheel gewas in het geval van de tweejarige bremteelt.

Hoewel in 1833 in de drie koloniën $\mathrm{I} 33$ ha brem aanwezig was, blijkt uit niets, dan in dit jaar ook aardappelen na brem zijn verbouwd. Ondanks de bremteelt had men alleen voor de gewone koloniën I 500 voer mest aangekocht, geheel bestemd voor het bouwland ${ }^{57}$. Alleen te Wateren is sprake van een proef op een viertal percelen met aardappelen na brem (totaal $2 \mathrm{ha}$ ). De opbrengsten waren kleiner dan na een gewone bemesting. Hierover schreef Van Konijnenburg: „Denkt men, bij dit alles aan den tijd, gedurende welke deze bremgrond renteloos heeft moeten liggen, - aan den arbeid, die het onderspitten van de brem gekost heeft en meer andere bezwaren, - waaronder ook nog, deze, min algemeen bekende, dat de aardappelen, op bremgrond geteeld, niet goed van smaak zijn, - hetgeen door de kolonisten in de gewone koloniën algemeen gezegd wordt, - dan zijn mij de uitkomsten van alle deze nieuwe proeven even onvoldoende als alle vroegere ${ }_{58}$. Hier bracht de directeur derhalve een nieuw element in de discussie, nl. de minder goede smaak van de aardappelen, verbouwd na brem.

In weerwil van de grote oppervlakte bremgrond (in de zomer I43 ha) is ook in 1834 slechts een proef genomen met aardappelteelt na brem, dit jaar op 7 percelen van totaal in ha, terwijl de gehele oppervlakte

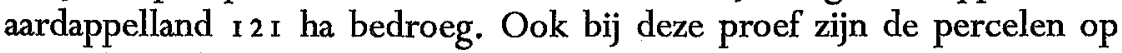
uiteenlopende wijzen bemest, n.l. met ondergespitte tweejarige brem, al dan niet met een halve of gehele gewone bemesting. Gemiddeld was de aardappeloogst per ha op de proefpercelen slechts $10 \%$ hoger dan op de overige I r 0 ha59. De commissie, die de koloniën in dit jaar inspecteerde, gaf in haar rapport over de bremcultuur de volgende veelbetekende conclusie: „De denkbeelden daaromtrent in de Koloniën zijn verschillend, en de gevoelens geheel inloopende tegen vroegere berigten, en als het ware in strijd met hetgeen daaromtrent door deskundigen is geschreven. Wij vonden het derhalve gewaagd, deswege onze denkbeelden te bepalen, en willen aan nader onderzoek en proefneming de beslissing overlaten, of het al dan niet raadzaam kan geacht worden, van die wijze van bemesting gebruik te maken." Het is wel zeker, dat de 
commissie met de deskundigen o.a. doelde op Van den Bosch als voorstander van de bremcultuur. Van den Bosch, die in hetzelfde jaar 1834 uit Oost-Indië naar Nederland terugkeerde en moest constateren, dat het door hem zo warm aanbevolen redmiddel voor de landbouw van de Maatschappij van Weldadigheid gedurende zijn afwezigheid feitelijk niet op grote schaal was toegepast en nog steeds in het experimentele stadium verkeerde! Wel gaf de commissie het advies aan elk gezin een tweede koe ter beschikking te stellen; dit achtte zij onontbeerlijk voor een behoorlijke bemesting.

Ongetwijfeld is het standpunt van de inspectiecommissie beïnvloed door de mening van Van Konijnenburg, die over i 834 aan de Permanente Commissie een uitvoerig overzicht zond van de verhouding tussen mestproduktie en oppervlakte cultuurgrond zonder rekening te houden met de bremteelt! Een dergelijke berekening heeft hij ook voor volgende jaren opgesteld aan de hand van bepaalde omrekeningsnormen ten aanzien van de mestproduktie van de verschillende diersoorten en de volwassen kolonisten. In bijlage 3 is als voorbeeld de verkorte becijfering weergegeven van de omvang der mestvoorziening in I 834, afzonderlijk voor de koloniën $\mathrm{I}$, Ir en IIr en Wateren.

Uit deze gegevens blijkt allereerst, dat het hooiland het zonder mest moest stellen evenals het boekweitveen. De hooilanden werden echter elk jaar bevloeid, waaraan men destijds veel waarde hechtte, terwijl het boekweitveen in het vroege voorjaar werd gebrand, waarna men de boekweit in de as zaaide. De berekende verhoudingscijfers tonen aan, dat de eigen mestproduktie het geringst was in kolonie III en het grootst te Wateren. De directeur constateerde hier dan ook een „betere verhouding tusschen teelderij en veehouderij, welke laatste nimmer aan zulke groote verliezen blootstaat als wel de eerste".

Tegenwoordig neemt men aan, dat een volwassen rund per jaar I $2.500-16.500 \mathrm{~kg}$ verse mest of 9.000-I $2.000 \mathrm{~kg}$ verrotte mest produceert (vaste en vloeibare mest met strooisel). Daar de mest ten tijde van de bemesting gedeeltelijk verrot is, is de door Van Konijnenburg gebruikte norm van 25 voer $=25.000$ pond $=12.500 \mathrm{~kg}$ te hoog te noemen. De norm voor de paarden is eveneens veel te hoog: Otten en Veenstra komen tot 2 paarden $=\mathrm{I}$ koe. Hetzelfde geldt voor de schapen. Genoemde schrijvers stellen 15 schapen $=\mathrm{I} \mathrm{koe}^{60}$.

Het jaar 1836 bracht een ommekeer in de koloniën ten aanzien van de toepassing van de brembemesting. Hoewel het Algemeen Verslag over I 835 slechts melding maakte van een proef met aardappelen na brem op een tweetal kleine akkers in de gewone koloniën en eenzelfde aantal te 
Wateren, was men toch "door de verkregen uitkomsten meer en meer bevestigd in de overtuiging van het uitstekend nut" en werden bevelen gegeven om in de gewone koloniën alle „ledigliggende” grond met brem in te zaaien. Deze grote wijziging in de opvatting van het Maatschappijbestuur is waarschijnlijk uitsluitend toe te schrijven aan de invloed van de inmiddels naar het vaderland teruggekeerde Van den Bosch 6 . Voor de algehele invoering van de bremcultuur liet hij goed zaad uit België komen.

Aan deze reorganisatie van de landbouw lag de derde verhandeling van Van den Bosch ten grondslag, waarin hij over de bemesting de volgende mening uitte ${ }^{62}$. Uit de vroegere proefnemingen, maar tevens uit die van I 834 en I 835 bij het 2de gesticht te Veenhuizen, was volgens hem gebleken, dat de mestkracht van I $\mathrm{mg}$ brem gelijk was aan die van twee koeien. Zo verkreeg men in 1834 zonder bijbemesting op bremgrond meer dan 200 mud aardappelen per bunder, in het droge jaar I 835 nog I 89 mud. Dit was meer dan het gemiddelde van de met stalmest bemeste grond. Als tweede gewas oogstte men in 1835 per bunder 22 mud rogge en in het volgende jaar waarschijnlijk nog een zeer goed gewas boekweit zonder enige verdere bemesting in 1834 tot en met I 836 . Voor elke met brem beteelde morgen kon men dus twee koeien minder aanhouden. Van den Bosch concludeerde: „Zoodanig eene kultuur ... zou dan volstrekt geen mest vereischen." De toch aanwezige koe- en sekreetmest kon men gebruiken om de vruchtbaarheid te verhogen en voor de teelt van handelsgewassen.

Door de invoering van een nieuw vruchtwisselstelsel zou I/3 à $\mathrm{I} / 4$ deel van de oppervlakte bouwland in de gewone koloniën des zomers met eenjarige brem zijn bezet. Verder werd voorgeschreven, dat hierbij het klaver-en vlasland sekreetmest zouden krijgen, het roggeland gedeeltelijk koemest en deels sekreetmest. Alle aardappelen moest men voortaan zonder enige verdere mest na brem telen. In zijn Verhandeling sloeg Van den Bosch de waarde van de sekreetmest nog weer hoger aan dan Van Konijnenburg (bijlage 3): „De secreetmest van een huisgezin, het opveegsel, zeepsop en water van de spijzen, dat doorgaans met eenig zout vermengd is, benevens de haardasch, goed behandeld, staan tenminste gelijk met de mest van eene koe", aldus de generaal. Van de tuintjes van 50 roeden per gezin moest naar zijn gevoelens de helft met brem worden beteeld. Hierna zou men met een weinig mest gedurende twee jaar zeer goede groenten kunnen verkrijgen.

De overschakeling op het nieuwe bouwplan met uitgebreide bremcultuur diende geleidelijk te geschieden, zodat het in I 839 (het vierde 
jaar) geheel zou zijn ingevoerd. Overeenkomstig de voorstellen van Van den Bosch stelde het bestuur van de Maatschappij de nodige besluiten vast en werd de directeur opgedragen de reorganisatie volgens de voorschriften te volbrengen.

Het effect van de bremcultuur kon dus eerst in r 839 geheel en al blijken. In de jaren van de overgangsperiode gaf men nog grote sommen uit voor de aankoop van mest (in 1836 ruim $f 16.000$, , in 1837 niet minder dan $\pm f 67.000$, - voor alle koloniën) ${ }^{63}$. Het Algemeen Verslag over I 837 vermeldt dan ook: „genoegzaam al de mest wordt tegenwoordig aangekocht". In de koloniën I en II was de mest te laat aanwezig om de rogge op tijd te kunnen zaaien, doordat de vaarten pas in november bevaarbaar waren. In dit jaar is voor bijna $f_{1}$ 900, - bremzaad gekocht ${ }^{64}$.

De grote omvang van de mestaankopen blijkt duidelijk uit het feit, dat in de gewone koloniën in 1838 de gebruikte mest voor $72 \%$ bestond uit aangekochte mest, voor $23 \%$ uit eigen stalmest en voor $5 \%$ uit sekreetmest van de kolonisten. Het hoge percentage gekochte mest was een gevolg van de inkrimping van de veestapel. Per morgen verbruikte men ruim ro० voer mest, hetgeen men zeker wel een zware bemesting kan noemen $(50.000 \mathrm{~kg})$. Te Wateren gaf men in dit jaar gemiddeld 70 voer per mg, hoewel de grondsoort hier minder vruchtbaar was dan in Frederiksoord en omgeving. Voor Wateren werd alleen eigen mest gebruikt, n.l. 97\% stalmest en $3 \%$ sekreetmest ${ }^{65}$.

In de oogststaten over 1838 maakte Van Konijnenburg voor de eerste maal gewag van proeven met beendermeelbemesting op $3 \mathrm{mg}$ gerst met klaver, die bijna niets opbrachten, en op aardappelen, die een matige oogst gaven.

Zoals gezegd was 1839 het eerste jaar, waarin de resultaten van de bremcultuur op grote schaal moesten blijken. Hoewel de aardappeloogst na brembemesting even groot was als na een gewone bemesting van 48 voer per $\mathrm{mg}$, bestaat de indruk, dat de hooggestemde verwachtingen van Van den Bosch niet werden bewaarheid. Weliswaar had men de aardappelen bijna overal op bremland kunnen poten, maar de brem was zeer ongelij]k van zwaarte en vertegenwoordigde gemiddeld slechts $2 / 3$ van een gewone bemesting. Plaatselijk was dan ook $\mathrm{r} / 3$ gewone bemesting toegevoegd ${ }^{66}$. In verband hiermede had men alleen voor de gewone koloniën bijna I I.000 voer mest elders moeten kopen, overeenkomend met $\pm 25 \%$ van de gehele hoeveelheid gebruikte mest. Volgens een berekening van de directeur maakte de brem ongeveer I $5 \%$ van het totaal uit ${ }^{67}$. De Maatschappij was dus nog steeds ten dele aangewezen op mestaankopen. 
Op grond van de opbrengstcijfers hield de Permanente Commissie echter vast aan de bremteelt. Bovendien waren de aardappelen na brembemesting in het algemeen smakelijker dan na een bemesting met stalmest, althans niet minder smakelijk, zo stelde de Permanente Commissie in de Vriend des Vaderlands ${ }^{68}$. In dit opzicht verschilde het bestuur van mening met de subcommissie uit de Commissie van Toezicht, die de koloniën in 1839 inspecteerde. In haar rapport, dat opvalt door de opbouwende kritiek, sprak de subcommissie ten aanzien van de bremcultuur nog van een "proeve”, ofschoon nimmer tevoren zo'n grote oppervlakte aardappelen na brem was verbouwd. Hoewel vooral de aardappelen, in de gewone koloniën (vrijwel) overal na brem gepoot, welig stonden, had het de aandacht van de subcommissie getrokken, „dat niemand, uit vrije verkiezing, van deze bemesting gebruik maakte of genegen was die te beproeven wegens de onaangename smaak van de aardappelen na brem". Dat de brem in 1839 niet overal goed groeide, blijkt ook uit de opmerking in het Algemeen Verslag, dat in de gewone koloniën 30.000 pond hooi was gewonnen van 12 ha bremland, waarop meer gras dan brem stond!

Ook bij de ontginning van veengrond, voor zover deze omstreeks I $84^{\circ}$ nog plaatshad, werd de bremplant direct ingeschakeld. Men vond het wenselijk in het eerste jaar na een dubbele stalmestgift aardappelen te verbouwen, vervolgens in het tweede jaar rogge na een enkele bemesting. Tegelijk met de rogge zaaide men 20 Nederlandse ponden bremzaad per ha. In de volgende herfst had men de beschikking over 40-50 pond brembemesting per are; na nog een jaar was dat 70-80 pond. Men zou dan afwisselend aardappelen, rogge met brem en brem kunnen telen zonder enige andere mesttoevoeging ${ }^{69}$.

In 1840 leverde $68 \mathrm{mg}$ aardappelen op uitsluitend brembemesting in de gewone koloniën gemiddeld $226 \mathrm{mud} / \mathrm{mg}$ op, hetgeen de directeur "zeer voldoende" noemde (het algemeen gemiddelde was $198 \mathrm{mud}{ }^{70}$. Ook verwachtte hij geleidelijk hogere roggeopbrengsten, naarmate de percelen alle met brem beteeld waren geweest ${ }^{71}$. Mogelijk kwam Van Konijnenburg langzamerhand tot een gunstiger oordeel over het nut van de bremcultuur; het is echter waarschijnlijker, dat hij noodgedwongen moest instemmen met het standpunt van Van den Bosch en de Permanente Commissie. Te Wateren gelukte de bremteelt niet naar wens. De directeur stelde dan ook voor de roggeteelt te Groot Wateren om de twee jaren af te wisselen met boekweit zonder enige bemesting in plaats van brem wegens de weinige werkzaamheden, die boekweit nodig had, het zuiver houden van het roggeland en de overvloed van grond 72 . 
Dat het bestuur van de Maatschappij bijzonder tevreden was over de resultaten van de bremteelt, blijkt uit de uitspraak in het Algemeen Verslag over $184^{\circ}$, gebaseerd op de eerdergenoemde opbrengstcijfers van de aardappelen:,$\ldots$ is het groote voordeel der brembemesting overtuigend gebleken". Ook de vrijboeren moesten voortaan de bremcultuur toepassen, hetgeen zij voordien uit eigen beweging niet hadden gedaan. Vrijboeren, die „niet genoegzaam vee” hielden, werden verplicht een deel van hun grond met brem te bezaaien op eigen kosten en onder toezicht van de directie. Een andere nieuwe maatregel, die was bedoeld ter vermijding van een te groot mestverbruik door de kolonisten-arbeiders op hun tuingrond, bepaalde, dat de directie jaarlijks de ligging van de tuin op elke hoeve zou aanwijzen.

's Zomers ging men in groten getale zaad plukken van de bremplanten om zelf in het benodigde zaaizaad ( 24 pond per ha) te kunnen voorzien. In augustus $184^{\circ}$ gingen de kinderen in de gewone koloniën alleen 's morgens naar school; 's middags moesten zij bremzaad plukken, waarvan men voldoende had geoogst om gedurende twee jaren alle roggeland te kunnen inzaaien 73 .

De Algemene Verslagen bleven voortaan het grote voordeel van de bremcultuur verkondigen, hoewel men er blijkbaar niet in was geslaagd alle aardappelen in de vrije koloniën uitsluitend met brembemesting te verbouwen. Het sprekendste nut van de brem gaven volgens het Verslag over I $84 \mathrm{I}$ de opbrengstcijfers van kolonie III aan:

23 ha op stoppelbrem (1-jarig) $25 \mathrm{Imud} / \mathrm{ha}$;

$\mathrm{r} 45$ ha op oude brem (2-jarig) $266 \mathrm{mud} / \mathrm{ha}$;

35 ha op gewone bemesting $234 \mathrm{mud} / \mathrm{ha}$.

Ook makkte dit Verslag voor de eerste maal melding van de teelt van rogge zonder enige bemesting na aardappelen met brembemesting. In I 84I leverde I 5,5 ha van deze rogge in kolonie I I $0,0 \mathrm{mud} / \mathrm{ha} \mathrm{op,} 3$ ha in kolonie III gaf r r, 2 mud/ha. „Deze uitkomst is belangrijk”, aldus het Verslag. De gemiddelde opbrengst van alle winterrogge bedroeg dit jaar 10,0 $\mathrm{mud} / \mathrm{ha}$, hetgeen zeker niet meer dan de helft van een normale oogst was.

De brem groeide in $184 \mathrm{r}$ zo goed, dat zij tegen de maaitijd op vele plaatsen hoger stond dan de rogge. Men vraagt zich af, hoe de rogge werd gemaaid. Dit vermeldt het Verslag helaas niet.

In 1842 zijn proeven genomen met roggeteelt na bemesting met stoppelbrem op ruim I ha, gedeeltelijk zonder, deels met toevoeging van een halve resp. gehele gewone bemesting. Omgerekend bedroeg de oogst per ha achtereenvolgens $25,7,26,3$ en 27,3 mud. Toevoeging van 
stalmest was dus niet nodig om een goed roggegewas te verkrijgen ( $\pm 23 \mathrm{mud} / \mathrm{ha}$ ). "Trouwens de stoppelbrem was dan ook best ...”, aldus Van Konijnenburg74.

De aardappeloogst in de gewone koloniën was in 1842 als volgt75 :

met stoppelbrem I 24,3 $\mathrm{mg}$ tegen I67 mud/mg;

met oude brem 92,4 ” I54 "

met gewone mest 5,0 ” I 54 ”

Genoemde $5 \mathrm{mg}$ bestond uit gescheurd groenland en nieuw ontgonnen grond. Men kan dus concluderen, dat in dit jaar alle aardappelen op het "oude" bouwland werden geteeld op bremgrond. De opbrengsten zijn echter niet zonder meer verkregen: op $80 \mathrm{mg}$ stoppelbrem had men een gewone bemesting gegeven, bij de oude brem slechts op $9 \mathrm{mg} \frac{\mathrm{I}}{2}$ gewone bemesting. Hieruit krijgt men de indruk, dat de brem, met name de stoppelbrem, toch niet zo best was. Bovendien blijkt, dat in $184 \mathrm{I}$ de aardappelen overwegend op 2-jarige brem, in 1842 echter meer op stoppelbrem zijn geteeld. Hierin is niet veel systeem te ontdekken.

De Algemeene Oogststaat van 1843 bevat verscheidene gegevens, die vermeldenswaard zijn. In dit jaar was de gezamenlijke waarde van de oogst van alle koloniën bijna $\mathrm{r} / 3$ groter dan die van $\mathrm{r} 842$ en overtrof eerstgenoemde de allerbeste oogst (van 1840 ) nog met $f$ 70.000, De Maatschappij van Weldadigheid bestond in 1843 juist 25 jaren; men verkreeg de laatste oogst tijdens het leven van de stichter Van den Bosch. Waarschijnlijk ook in verband met deze omstandigheid weidde Van Konijnenburg uit over de voordelen van de brembemesting. Hij schreef de "ongewoon groote opbrengst van het jaar 1843 " in de eerste plaats toe aan het gunstige weer, in de tweede plaats aan de brem: „... onwedersprekelijk te danken aan de voortzetting en uitbreiding der bremcultuur, die, hoe meer dezelve over alle stukken lands is gebragt geworden, de teelstof in den grond vermeerdert, de ontzuring van denzelven bevordert en alzoo de groeikracht in denzelven verhoogt". De $30 \%$ brembemesting in de gewone koloniën was z.i. dan ook „nog voor eene aanzienlijke toeneming vatbaar".

Het volgende overzicht geeft de verhouding van de verschillende mestbronnen in 1843 weer.

De verhoudingsgetallen van tabel 6 zijn gebaseerd op een oppervlakte brembemesting in de gewone koloniën van $195 \mathrm{mg}$ stoppelbrem en 89 $\mathrm{mg}$ tweejarige brem en te Wateren $8 \mathrm{mg}$ tweejarige brem. Van Konijnenburg stelde I mg stoppelbrem gelijk met $3 \circ$ voer, I $\mathrm{mg}$ tweejarige brem met 60 voer dierlijke mest per mg. Het valt op, dat te Wateren de dier- 
Tabel 6 - BEMESTIN GSBRONNEN IN I 843

\begin{tabular}{lcc}
\hline Mestsoort & \multicolumn{2}{c}{ Gebruikte hoeveelheid in \% in } \\
\cline { 2 - 3 } & gewone koloniën & Wateren \\
\hline Dierlijke mest & 32 & 79 \\
Brembemesting & 30 & 15 \\
Sekreetmest & 22 & 6 \\
Aangekochte mest & 16 & - \\
\hline Alle soorten & & 100
\end{tabular}

Bron: Algemeene Oogststaat van 1843 .

lijke mest zeer belangrijk was. In de gewone koloniën werd relatief twee maal zoveel brembemesting toegepast als te Wateren. Niettemin was men toch nog genoodzaakt voor $f 7729$,- mest aan te kopen, zodat de gewone koloniën nog steeds niet zelfverzorgend waren ten aanzien van de mestvoorziening.

Andere bemestingsbronnen werden daarom aangeboord. Zo waren in I 843 uit opgeschoonde en uitgediepte sloten "veel dienstbare bijstoffen” vooral over het groenland gebracht. Een nieuwe meststof meende men te hebben gevonden in het vocht uit de aardappelmaalderij, waar aardappelmeel werd bereid voor de koloniale broodbakkerij ter vermenging met roggemeel. Bij wijze van proef was dit vocht met al het spoelsel in zijn geheel als meststof gebruikt in plaats van de bezonken stof, verkregen door indampen. Deze proef had ,zoo zeer voldaan, dat dit water tegenwoordig in al de koloniën met de meeste spaarzaamheid verzameld en aangewend wordt, hetgeen eene belangrijke aanwinst van meststof uitmaakt, waarvan zeer veel mag worden verwacht", zo schreef Van Konijnenburg in optimistische bewoordingen aan de Permanente Commissie in de Algemeene Oogststaat van r 843. Hij voorzag een gunstige toekomst voor de landbouw, o.a. vanwege de zorgvuldige mestverzameling en de uitbreiding van de brembemesting.

Als de grond hierdoor na enige jaren aanmerkelijk zou zijn veredeld, zou deze ook geschikt zijn voor andere gewassen dan rogge, boekweit en aardappelen, zoals b.v. groene erwten en duivebonen, die te Wateren in r 843 bijna geheel waren mislukt ${ }^{76}$. Ook had men in de koloniën I en III een proef genomen met de teelt van winterkoolzaad en tarwe op viermaal een halve mg "bestjarige" brem met een halve gewone bemesting van $3 \circ$ voer stalmest per mg77. 
In de Staat van den Haver-oogst in I 843 verklaarde Van Konijnenburg tenslotte over de brem: „De brem, welke hier en daar onder de haver gezaaid is, is als gewoonlijk wederom slecht voortgekomen ..." Als oorzaak wees hij op de grotere bladrijkheid en dichtheid van haver ten opzichte van rogge. Dit was nog sterker het geval bij brem onder boekweit, waarbij de brem alleen aan de randen van de percelen enigszins groeide. Als dekvrucht voor brem verkoos de directeur dus de rogge.

Uit zijn opmerkingen bij de Staat van den Rogge-Oogst in I 844 blijkt, dat de bremcultuur het nadeel had, dat de grond meer vervuilde met onkruid. De geringe roggeoogst in dit jaar werd plaatselijk mede veroorzaakt door de vuilheid van het land. „Dat de brem-cultuur onkruid veroorzaakt is niet tegen te spreken, doch door de brem voortaan meer overjarig dan als stoppelbrem te bezigen, zal dat nadeel grootelijks worden voorgekomen." In tegenstelling tot voorgaande jaren waren de aardappelen in I 844 weer overwegend op tweejarige bremgrond verbouwd. De resultaten waren als volgt:

I 66,7 ha met 2-jarige brem: $28 \mathrm{r} \mathrm{mud} / \mathrm{ha}$;

24, 5 ha met stoppelbrem $+\frac{1}{2}$ gewone bemesting: $237 \mathrm{mud} / \mathrm{ha}$;

2, I ha oud groenland met hele gewone bemesting: $235 \mathrm{mud} / \mathrm{ha}$;

1 5,7 ha nieuw land met drievoudige gewone bemesting: I $35 \mathrm{mud} / \mathrm{ha}$.

Het commentaar van de directeur hierbij was zeer positief:

"Waar daden spreken, behoeven geene woorden verspild te worden!"78

In het Algemeen Verslag over 1844 wijdde de Permanente Commissie toch nog enkele juichende woorden aan deze uitkomsten: „Deze uitkomsten ... zijn belangrijk en stellen, zoo het nodig ware, in het helderst licht de voortreffelijkheid en het voordeel van de aardappelbouw op eenjarigen bremgrond" (men bedoelde hier tweejarige brem). Objectief gezien kan echter geen enkele conclusie uit deze en andere soortgelijke cijfers worden getrokken, daar geen vergelijkingspercelen op oud bouwland met uitsluitend gewone bemesting waren aangelegd.

Een tweede proef met tarwe na beste tweejarige brem zonder andere bemesting was wederom "genoegzaam mislukt, zoo ten gevolge der vuilheid van den grond, als van het sterk afwisselende winter-weder". In de Algemeene Oogststaat van 1844 komt in dit verband de opmerking voor, dat men door middel van brem geen tarwe kon verbouwen op zandgrond.

Deze Oogststaat vermeldt ook, dat in 1844 ongeveer $1 \frac{1}{2}$ maal zo veel brem had overgestaan als in 1843 . „Zulks verzekert een goed aardappel- 
verbouw, met besparing van meer dierlijke meststof voor de graan-teelt." Hierop volgt dan de typerende uitspraak, dat naarmate de aardappelplanten door meer loof de grond beter zouden bedekken, „zoo minder voedsel ontrooft de vrucht aan den grond, ook door eene ruimere atmospherische bemesting en blijft die dus voor de opvolgende roggeteelt te beter". In die dagen veronderstelde men nog, dat de planten de voedingsstoffen in het algemeen zowel uit de lucht als uit de grond konden opnemen.

Van Konijnenburg pleitte ervoor te zorgen, dat geen gewas zou kunnen mislukken door onvoldoende bemesting. „Een arme boer heeft om de drie jaar een misgewas, een rijke slechts om de zeven."

Een klein stuk nieuwe grond, bemest met water uit de aardappelbroodbakkerij, leverde 240 mud aardappelen per ha op. Als meststof voldeed poortaarde minder dan straatvuil, vooral op nieuwe grond79. Ook tegenwoordig is compost, bereid uit straat- en huisvuil, een belangrijke meststof voor ontginningsgrond.

In $1844 / 45$ nam de Maatschappij van Weldadigheid voor de eerste maal bemestingsproeven met guano, vogelmest uit Zuid-Amerika, vooral uit Peru. Hiertoe werden $4 \times 2$ gelijke percelen, in de koloniën I en III, beteeld met rogge. 4 percelen hadden koemest gekregen ter waarde van $f_{50}$,- (excl. de kosten van oprijden), de 4 andere percelen waren voor eenzelfde waarde bemest met guano. De reeks met koemest bracht gemiddeld 1 7, 2 mud per ha, de guanoreeks I4, I mud/ha op. De guano, die in Amsterdam was gekocht, voldeed het best, in droge toestand meer dan nat. Niettemin concludeerde Van Konijnenburg80, dat het verschil tussen guano en koemest „niet van belang was”. „Goedkooper acht ik de Guano dus thans nog niet." Guano scheen een "meer opwekkend dan voedend vermogen" te bezitten. Op nieuwe grond zonder humus voldeed de guano nog minder.

In het landbouwkundige gedeelte van het verslag van het inspectiebezoek in I 846, verzorgd door Staring, is een tweetal bladzijden gewijd aan de mestsituatie ${ }^{81}$. Het oordeel van Staring over de behandeling der eigen stalmest was onverdeeld gunstig, althans wat betreft de gewone koloniën. Als strooisel werd stro gebruikt. De aankoop van poortaarde of sekreetmest uit Amsterdam en straatvuil, in I 845 voor $f$ i 7.765, - voor alle koloniën, achtte Staring geheel verantwoord. Ondanks de brembemesting, geschat op $\frac{1}{4}$ van de benodigde mesthoeveelheid, was de veestapel onvoldoende om de cultuurgrond behoorlijk te voorzien.

Uit de zin „De brembemesting blijft tot dusverre volkomen aan de verwachting voldoen" kan men afleiden, dat Staring gunstig stond ten 
opzichte van de bremcultuur. Dit blijkt ook uit zijn verdere beschouwing. Het is evenwel niet duidelijk, of ook hij tevoren zulke grote verwachtingen omtrent de brem had als Van den Bosch. In de gewone koloniën, waar de grond minder humusrijk was, stond de brem volgens Staring echter niet zo goed als te Veenhuizen en te Ommerschans op de dalgronden. Hij raadde daarom aan de brem met grotere tussenpozen op dezelfde percelen te verbouwen. Tot dusverre scheen de brem niet te lijden onder een veelvuldige teelt op dezelfde akkers: te Veenhuizen waren sommige sinds 1823 reeds achtmaal met brem ingezaaid, die nog steeds een goed gewas gaf. Toch achtte Staring het waarschijnlijk, dat eenmaal het land de brem niet meer zou kunnen voeden; de ondervinding moest dit leren. Zijn conclusie luidde: „Wijsselijk doet alzoo de Maatschappij, door vooreerst nog van dit hulpmiddel ruimschoots gebruik te maken, terwijl het niet te weerspreken is, dat, bij de waarde van den bodem in de Koloniën, het verlies van een jaar opbrengst aldaar ruim wordt opgewogen door het winnen eener voldoende bemesting voor een aardappelgewas." Staring gaf dus bepaald geen afwijzend oordeel over de brembemesting.

In 1847 werd in de vrije koloniën op niet minder dan 204 ha van de 2 Io ha aardappelland brembemesting toegepast, n.l. 145 ha met tweejarige brem en 59 ha met stoppelbrem met een halve gewone bemesting. De opbrengst per ha bedroeg resp. 161 en $198 \mathrm{mud}^{82}$.

Voor de zaadwinning liet men voortaan geen brem meer staan; het zaad werd geplukt van de opslag langs sloten, greppels, wallen, heggen en bossen. Zo was in 1847 in de gewone koloniën $45^{\circ}$ pond, te Wateren roo pond bremzaad verkregen (ongeveer $\mathrm{I} / 3$ van de behoefte). Als benodigde hoeveelheid zaaizaad is in dit jaar opgegeven 18 pond per ha, d.i. aanmerkelijk minder dan in vroegere vermeldingen (b.v. in $1840: 24$ pond per ha) $)^{83}$.

Twee jaar later sprak Van Konijnenburg van 20 pond bremzaad, die per ha was ingezaaid onder rogge. De zaaizaadhoeveelheden wisselden dus nogal. Ook schreef hij over de stoppelbrem, „die echter doorgaande weinig aanbrengt ..."84.

Het is opvallend, dat in de oogststaten vanaf 1848 weinig meer is geschreven over de bremcultuur in het algemeen en nog minder over de voordelen. Mogelijk stond de brem in deze jaren ook minder in de belangstelling door de op grote schaal optredende aardappelziekte, die aller aandacht in beslag nam.

Evenals in $185 \mathrm{I}$ was de bremzaadoogst in 1852 zo groot, dat vrijwel geen zaad behoefde te worden gekocht. In alle koloniën had men de 
ondervinding opgedaan, dat „zaadbrem een minder vruchtbaren grond dan jarige brem achterlaat, hetgeen men vroeger niet zoo had waargenomen"85.

Om over meer mest te kunnen beschikken is de schapenstapel te Wateren omstreeks I 850 aanzienlijk uitgebreid tot 1200 stuks in $185^{1}$. Als verklaring voor de telkenjare relatief grote roggeoogsten te Wateren voerde Van Konijnenburg aan „het gebruik van meer hete schapenmest ..., die de boeren mede voor de rogge-cultuur verkiezen". De schapenmest werd vermengd met heideplaggen. Te Wateren verbouwde men vrijwel alle rogge met deze mest, in kolonie II een zeer klein gedeelte. In de vrije koloniën $\mathrm{I}$, II en III waren de opbrengsten van de rogge in $185^{\circ}$ en $185 \mathrm{I}$ blijkbaar geringer dan in de omgeving. In dit verband was de directeur niet tevreden over de stalmest: „Het is alsof de koloniale mest niet in dien vereischten staat van broei te velde gebragt wordt; althans mist zij veelal die sterke amoniak-lucht, die men over de roggelanden, buiten de koloniën gaande, overal waarneemt, wanneer ze bemest worden"86.

Vooral de Oost- en Westvierdeparten (2 de wijk van kolonie iI) bleven achterlijk in opbrengsten. Dit was een gevolg van de hoge ligging en onvruchtbaarheid van de grond. Om deze te verbeteren, aldus het Algemeen Verslag over i $85^{2}$, zijn tegen het eind van dit jaar ook voor kolonie II meer schapen aangekocht, terwijl tevens andere meststoffen zijn aanbevolen. Van de brembemesting werd in dit verband met geen woord gerept.

Men kan inderdaad wel concluderen, dat de directeur Van Konijnenburg langzamerhand was teruggekeerd tot zijn oorspronkelijke opvattingen over de mestvoorziening, t.w. de noodzaak van meer stalmest en een zeker scepticisme wat betreft de brembemesting. De eertijds zo veelvuldige opmerkingen over de grote voordelen van de bremcultuur, die de aankoop van stalmest overbodig zou maken, bleven volledig achterwege. Zo schreef de directeur bij de Algemeene Oogststaat van I 855 , dat het in de gewone koloniën voornamelijk ontbrak aan de nodige mest, "welk gebrek in deze koloniën hoe langer zoo meer wordt gevoeld, een gevolg van den betrekkelijk geringen veestapel en de moeylijkheid om aangekochte mest aangevoerd te krijgen, ter oorzake van het gebrekkige vaarwater, hetwelk de rivier de Linde oplevert".

Niettemin vergrootte de directie de mestaankopen, hetgeen blijkt uit de gegevens van de Algemeene Oogst-Staat van r856. Bedroeg het bedrag, uitgegeven voor mestaankoop, in 1855 voor alle koloniën $f 16.500$, - en voor de gewone koloniën alleen reeds bijna $f$ 9300, 一, 
het volgende jaar waren deze sommen respectievelijk ruim $f$ 29.000,en bijna $f 16.000$,- - Voor Wateren waren echter in beide jaren (en ook daarvoor) geen mestaankopen nodig geweest.

Elders ging hij nader in op het verschil in mestvoorziening en oogstresultaten tussen de gewone koloniën en Wateren ${ }^{87}$. Ten aanzien van de rogge stond Wateren doorgaans bovenaan bij alle koloniën. Dit werd niet veroorzaakt door verschil in grondsoort. „Maar die bijzondere omstandigheid is gelegen in het gebruik van schier het dubbel der mest van de andere koloniën en welke, daar en boven, uit veel meer dierlijke mest-stoffen bestaat ..." Te Wateren gaf men per ha rogge ruim 90 voer mest, w.v. $10 \%$ groenbemesting, elders slechts 45 voer, w.v. ruim $25 \%$ groenbemesting, hoofdzakelijk brem. Ook hier voerde de directeur dus een pleidooi voor meer stalmest. De in 1856 grotere roggeopbrengst, vergeleken met I 855 , schreef hij toe aan de grotere aankoop van mest (voor $f 6700$, - meer). Volgens een potloodaantekening bij deze oogststaat, waarschijnlijk geplaatst door een lid van de Permanente Commissie, bedroeg de meeropbrengst van de rogge echter slechts $f$ 1780,(à $f$ r o,- - per mud). Uit deze aantekening blijkt, dat men het slechts ten dele met de directeur eens was. De meeropbrengst woog niet op tegen de meerdere kosten van de mest.

Het jaar 1857 is het laatste, waarvan de door Van Konijnenburg samengestelde oogststaten in het oud archief van de Maatschappij aanwezig zijn. Hieruit is het onderstaande bemestingsoverzicht afgeleid.

Tabel 7 - ENKELE MESTBRONNEN IN I 857

\begin{tabular}{|c|c|c|c|c|c|}
\hline \multirow{2}{*}{ Kolonie } & \multirow{2}{*}{$\begin{array}{l}\text { Beteelde } \\
\text { oppervlakte } \\
\text { in ha }\end{array}$} & \multicolumn{2}{|c|}{ Oppervlakte brem } & \multicolumn{2}{|c|}{ Mestaankoop in guldens } \\
\hline & & in ha & in $\%$ van 2 & totaal & per ha $(2-3)$ \\
\hline $\mathbf{I}$ & 2 & 3 & 4 & 5 & 6 \\
\hline $\mathrm{I}$ & 364 & 60 & 17 & 3.800 & $12,5^{\circ}$ \\
\hline II & 241 & 37 & 15 & 3.000 & 14,70 \\
\hline III & 429 & 78 & 18 & 5.600 & 16,- \\
\hline$I+I I+I I I$ & 1.034 & 175 & I 7 & 12.400 & $14,4^{\circ}$ \\
\hline Wateren & 104 & I 2 & 12 & - & - \\
\hline
\end{tabular}

Bron: Staat der teveld staande Gewassen in den Zomer van 1857. 
Moest volgens het plan van Van den Bosch ${ }^{88}$ omstreeks $25-35 \%$ van het bouwland des zomers met brem zijn bezet, in 1857 waren deze percentages aanmerkelijk kleiner, vooral te Wateren. Hoewel het bedrag, uitgetrokken voor de aankoop van mest, in 1857 lager was dan in het voorafgaande jaar, was deze mestbron toch zeker niet van belang ontbloot, met name in de koloniën II en III. Alleen te Wateren kon men het stellen zonder aangekochte mest.

De rogge-oogst in de koloniën was in I 857 ,wederom gebleven verre beneden de opbrengst daarbuiten". Dit verschil zou voornamelijk zijn te wijten aan „vervuiling van den grond, nog meer welligt dan aan eene onvoldoende bemesting. De brem groeit niet meer zo welig als in vroegere jaren; de aardappelen, die daarop worden geteeld, waren gedurende het heerschen der aardappelziekte, niet meer zoo zwaar van lof, door welk een en ander de kweek en ander onkruid zoo zeer de overhand heeft verkregen, dat de groei van het graan er door benadeeld wordt en de zaadgeving steeds gering is." Op deze wijze schilderde Van Konijnenburg een somber beeld van de landbouw in de vrije koloniën te Frederiksoord en omgeving 89 , een beschrijving, die men tevergeefs zoekt in de officiële gepubliceerde jaarverslagen van de Maatschappij.

Uit het voorgaande is te concluderen, dat de mestvoorziening van de landbouwkoloniën der Maatschappij van Weldadigheid tot 1859 voortdurend een probleem van de eerste orde is geweest. Ondanks de toepassing van het wondermiddel van de brembemesting heeft de Maatschappij nooit voldoende in de eigen mestbehoefte kunnen voorzien. Het is in dit verband van belang te constateren, hoe enkele ter zake kundige schrijvers het bemestingsvraagstuk bij ontginningen in het algemeen en bij de Maatschappij van Weldadigheid in het bijzonder in de vorige eeuw beoordeelden.

Verscheidene malen heeft de eerdergenoemde ontslagen adjunctdirecteur der Maatschappij Wardenburg, die zich nadien als advocaat te Steenwijk vestigde, zijn gedachten hierover gepubliceerd. In 1829 reeds gaf hij een uitvoerige verhandeling uit over de ontginning van woeste zand- en veengronden, feitelijk een verzameling opstellen, die de redactie van de Vriend des Vaderlands had geweigerd in het tijdschrift van de Maatschappij op te nemen. Uit hetgeen hij mededeelde over de brembemesting90 blijkt, „dat onderscheidene heiontginners eene ongemeene waarde aan den aanbouw van Brem gehecht, en de ontginning der woeste gronden door middel van deze plant voorgeslagen hadden". Bovendien vormde de brem z.i. een goed voedsel voor de schapen. Wardenburg gaf vervolgens de ervaringen weer van de Vlaming Frans de Coster ${ }^{91}$, die 
zich in de omgeving van Antwerpen vele jaren lang had bezig gehouden met de ontginning van heide. Op grond van genomen proeven durfde deze de brembemesting aan iedereen aan te bevelen. Het betrof hier de teelt van driejarige brem, waarvan de groene takjes werden ondergeploegd voor een volgend roggegewas zonder of met een halve gewone bemesting. De stammen van de driejarige brem waren als brandhout te gebruiken. Over de aardappelteelt na brem sprak Wardenburg niet. De Coster meende wel, dat men ook na onderploegen van eenjarige brem rogge kon telen. Wardenburg gaf als zijn mening, „dat de onder de rogge gezaaide brem, wanneer dezelve goed slaagt, het koren aanmerkelijk in deszelfs wasdom benadeelt, terwijl men de akker drie jaren moet ontberen, om in het vierde jaar vruchten te trekken". Niettemin achtte hij de bremteelt, vooral bij ontginning, nuttig voor kleine boeren. Van den Bosch was dus niet de enige voorstander van de bremcultuur.

Bijna $3 \circ$ jaar later was Wardenburg blijkens een artikel van zijn hand 92 van gedachten veranderd in die zin, dat hij de teelt van tweejarige brem onder rogge om vervolgens zonder andere mest aardappelen te verbouwen, zoals sinds geruime tijd in de koloniën van de Maatschappij van Weldadigheid geschiedde, als onvoordelig beschouwde. Hij somde tenminste alleen een reeks nadelen op:

1. stalmest werkte beter in op de ontbinding van de grond;

2. een deel van het roggestro ging verloren, doordat men hoger moest maaien;

3. men ontbeerde een stoppelvrucht (spurrie of knollen);

4. in het volgende jaar had men ook zonder bemesting een boekweitoogst kunnen verkrijgen;

5. het onderspitten of -ploegen van de brem vergde veel arbeid;

6. kweek en ander onkruid woekerden sterk onder de brem;

7. de hoeveelheid grond in de koloniën was onvoldoende om de bevolking te voeden; niettemin werd door de bremteelt veel grond "braakgelegd";

8. men kon beter, na onderploegen van een stoppelgewas na de rogge, in het volgende jaar zwarte haver telen zonder verdere bemesting. De opbrengst zou ongeveer 40 mud zaad en een grote hoeveelheid voerstro per ha bedragen.

Wardenburg constateerde dan ook, dat de brembemesting bij geen der naburen van de Maatschappij navolging had gevonden. De teelt was alleen te rechtvaardigen door de uitzonderlijke toestand van de landbouw en de financiën van de Maatschappij. Hij beval als groenbemesters aan de 
witte lupine (Lupinus albus), de reinvaren (Tenacetum vulgaris) en in het bijzonder de kegeldistel (Echinops bannaticus).

In hetzelfde jaar leverde Wardenburg in een brochure vrij scherpe kritiek op de Maatschappij van Weldadigheid, vergezeld van enige suggesties voor de toekomst ${ }^{93}$. De in de koloniën berekende hoeveelheid mest van twee koeien en één gezin per drie mg moest men naar zijn mening met minstens $\mathrm{I} / 3$ verminderen in verband met de karige voeding van het vee. Men gebruikte „krachtelooze surrogaten” als raapkoekenmeel, mengsels van kalk en veen en van heideplaggen en mest van "half verhongerde schapen".

Verder deelde Wardenburg als zijn mening mede, dat de Permanente Commissie alle middelen bezigde om de ongunstige stand van zaken te bedekken. Het ontbrak echter niet aan deskundigen, die meenden, dat de Maatschappij haar "onvermijdelijken ondergang te gemoet snelde”, door de Permanente Commissie „zendelingen der kwaadwilligheid" genoemd.

Vele deskundige bezoekers merkten de ongunstige toestand van de landbouw op. Zo schreef één der bezoekers in het boek, dat door de Permanente Commissie was neergelegd in het logement van Crusinga, bij het bedelaarsgesticht Ommerschans, om de lof van de stichter te bezingen:

\author{
„O, edele Maatschappij! \\ Gij weert de bedelarij, \\ God geef U Zijnen zegen \\ En schenk U eenen strondregen."
}

Aldus de criticus Wardenburg.

Over de invoering van de brembemesting zei Van Konijnenburg in 1859, dat hij van tegenstander tot voorstander was geworden. Hij gaf echter toe, dat men na $\pm 185^{\circ}$ op oudere grond slechte resultaten verkreeg. De bremgroei werd minder, de hoeveelheid kweek nam evenwel toe. Soms was op enige afstand geen verschil te zien tussen aardappelland en grasland! Ook het gebruik van gips, beendermeel, beenzwart en guano, waaraan hoge kosten waren verbonden, gaf onvoldoende resultaat 94 .

Ten aanzien van de bremteelt was men tot de ervaring gekomen, dat de grond werd uitgeput. Men pleegde op deze wijze jarenlange roofbouw op grote schaal. De grond keerde hier en daar letterlijk tot zijn oorspronkelijke toestand terug, aldus Eilerts de Haan in $187^{95}$. Elders 
vermeldde hij, dat ook de bossen waren verarmd, doordat men de humuslaag uit de bossen op het bouwland bracht ${ }^{96}$.

De eerste directeur van de Maatschappij na de reorganisatie van I 859 , Jongkindt Coninck, noemde de bremteelt een "eigenaardige cultuur". Ondanks de dalende tendens in de opbrengsten van rogge, aardappelen, boekweit en haver in de periode 1848 -1 $85^{8}$ en de minder goede resultaten van de bremteelt had men destijds geen wijziging gebracht in de vruchtwisseling97.

Samen met Enklaar heeft Jongkindt Coninck een verklaring gevonden voor de achteruitgang van de bremteelt ${ }^{98}$. Deze luidt aldus: de brem bevat in zijn houtige delen veel kalium; de plant neemt deze stof met zijn lange wortels op uit de diepere ondergrond. De aardappel, die op bremgrond wordt geteeld zonder andere bemesting, neemt op zijn beurt de kalium weer op uit de met brem bemeste bovengrond. Op den duur raakt de ondergrond uitgeput, zodat de brem minder goed groeit en ook de aardappelplanten een geringere opbrengst gaan geven. Men kwam dan ook tot de overtuiging, dat de brem op oude grond na verloop van een aantal jaren volstrekt niet groeide en alleen op pas ontgonnen grond gunstige resultaten opleverde. Het duurde echter tot na 1859 , voordat men zich dit in de koloniën voldoende realiseerde. Volgens Jongkindt Coninck namen de boeren in de omgeving van de koloniën ook proeven met de bremteelt, waarbij zij tot dezelfde conclusie kwamen.

Bovenstaande uiteenzetting lijkt een aanvaardbare verklaring voor de praktijkervaring met de bremteelt. Het is overigens wel opvallend, dat men in de literatuur van de r 9 de eeuw geen woord vindt over de belangrijkste functie van de brem als vlinderbloemige, nl. de vastlegging van stikstof uit de lucht in de grond door een bacterie (Bacterium radicicola), die de vorming van wortelknolletjes veroorzaakt. Hiervan was men destijds blijkbaar nog niet op de hoogte.

De mestvoorziening van de koloniën der Maatschappij van Weldadigheid heeft dus voortdurend grote moeilijkheden opgeleverd. In de periode tot 1859 hebben de gewone koloniën nimmer in de eigen behoeften kunnen voorzien. Deze ongunstige factor, voortkomend uit het eenzijdige produktieplan met het zwaartepunt zeer sterk op de akkerbouw, was bepalend voor de over het algemeen onbevredigende opbrengsten van de gewassen.

Welke akkerbouwgewassen in de koloniën werden geteeld, zal in het volgende gedeelte van deze paragraaf ter sprake komen bij de behandeling van de vruchtwisseling. 


\section{b. De vruchtwisseling}

Reeds in zijn eerste verhandeling van 18 r 8 hield Generaal Van den Bosch zich bezig met de in de koloniën toe te passen vruchtwisseling. Zoals hiervoor is vermeld, beval hij een stelsel aan met rapen of brem als groenbemestingsgewas op de helft van de oppervlakte cultuurgrond. In het door hem uitvoerig beschreven werkprogramma voor de eerste jaren na de aankomst van de kolonisten 99 kwam hij in het derde jaar tot een volledig gebruik van de ontgonnen twee $\mathrm{mg}$ bouwland ( $=\mathrm{r}, 7_{7} \mathrm{ha}$ ) per hoeve in vier percelen van $\frac{1}{2} \mathrm{mg}$ met de gewassen:

I. rogge met brem als ondervrucht;

2. brem;

3. aardappelen;

4. boekweit.

Van den Bosch stelde dus een eenvoudige vierjaarlijkse vruchtwisseling voor. $\mathrm{Na}$ de oogst van de rogge zou op deze wijze inderdaad de halve oppervlakte van elke hoeve brem dragen. De in de praktijk toegepaste vruchtwisselstelsels weken echter in belangrijke mate af van bovenstaande gedachten van de stichter der koloniën.

Hij heeft de werkelijke gang van zaken beschreven in zijn tweede verhandeling van $1820^{100}$. Inplaats van $2 \mathrm{mg}$ was elke hoeve $3 \frac{\mathrm{I}}{2} \mathrm{mg}$ of 2100 roeden $(=3 \mathrm{ha})$ groot, waarvan 200 roeden in twee gelijke percelen afwisselend met groenten en vroege aardappelen werden beteeld en derhalve als tuingrond verder buiten beschouwing kunnen blijven. Van de resterende oppervlakte werden 300 roeden bestemd voor fioringras, dat enkele jaren achtereen bleef staan voor hooiwinning.

De eigenlijke vruchtwisseling had plaats op de vier percelen van 400 roeden $(=0,6$ ha) en was in $\mathrm{i} 820$ van de volgende vorm:

I. gerst met klaver als ondervrucht;

2. klaver;

3. rogge met knollen als nagewas;

4. aardappelen.

Dit was het z.g. Norfolkse systeem met dit verschil, dat de tarwe was vervangen door rogge en aardappelen de plaats van de voederknollen innamen. Het Norfolksysteem is omstreeks r 800 uit Engeland overgenomen door de verlichte grootgrondbezitters in verschillende andere westeuropese landen ${ }^{10 x}$. Bij gebrek aan voldoende bremzaad verving Van den Bosch dus de brem van zijn oorspronkelijke stelsel door klaver 
(met raaigras), die tevens ruwvoeder leverde. Als dekvrucht verbouwde men gerst, terwijl de boekweit was vervangen door rogge. Al met al zeker een intensief vruchtwisselingssysteem, dat stellig gunstig afstak bij het destijds door de Drentse boeren gevolgde stelsel. In het bijzonder is het opvallend, dat in de koloniën reeds in $\mathrm{I} 820$ wisselbouw werd toegepast en de graangewassen werden gecombineerd met een ondervrucht of nagewas.

Van den Bosch vermeldde echter, dat in de eerste jaren door de omstandigheden van de aanloopperiode veel heeft ontbroken aan deze voorgeschreven vruchtwisseling. In 1820 is dit stelsel in kolonie I geheel ingevoerd.

In Von Grouners reisbeschrijving, die betrekking heeft op de jaren I $821 /$ I 822 , treft men reeds een gewijzigd rotatiesysteem aan ro2, dat neerkomt op de volgende cyclus :

I. zomerrogge met klaver;

2. klaver;

3. klaver;

4. rogge;

5. vlas ( $100 \mathrm{r}$ ), aardappelen ( $5 \circ \mathrm{r}$ ) en groenvoer ( $100 \mathrm{r})$;

6. rogge;

7. aardappelen;

8. rogge.

De tuingrond was verminderd tot $\mathrm{r} \circ 0 \mathrm{r}$ en het perceel fioringras had men laten vervallen. Bovenstaand stelsel werd dus toegepast op 8 percelen van slechts $250 \mathrm{r}(=0,36 \mathrm{ha})$. De oppervlakte graan was vergroot tot rooo $\mathrm{r}$, waarbij de gerst was vervangen door rogge. De groenvoederverbouw was ingekrompen (tot $600 \mathrm{r}$ ), evenals de aardappelteelt (tot $300 \mathrm{r}$ ). Als nieuw gewas deed het vlas zijn intrede. Het teeltplan bestond dus uit:

$50 \%$ rogge,

$30 \%$ voedergewassen,

$15 \%$ aardappelen en

$5 \%$ vlas.

Von Grouner vermeldde verder, dat de rogge niet alleen als zaadrogge werd verbouwd, maar ook veel als groenvoeder. Hiertoe zaaide men de rogge het gehele jaar door van maart tot in december. De snijrogge groeide op goed bemeste zandgrond snel en leverde goed voer op. De snelle groei liet voor of na de rogge nog een gewas boekweit of spurrie (Spergula arvensis) toe. 
De percelen groenvoedergewassen droegen voornamelijk rode klaver (Trifolium pratense), evenwel steeds gemengd met raaigras (Avena elatior) na zomergraan. Destijds werd het land vóór de teelt van de zomerrogge bemest, terwijl men vervolgens het klaverland in de herfst van het eerste jaar stalmest gaf en in het volgende voorjaar turfas of nogmaals korte mest. De opbrengst was doorgaans buitengewoon en zonder weerga, aldus Von Grouner. De klaver werd $3 \frac{1}{2}$ à 4 voet hoog en gedroogd volgens de z.g. Klappmaierse methode in hopen, hetgeen goed voldeed. Van den Bosch had ervaren, dat de klaver ook voortreffelijk groeide onder boekweit (Polygonum fagopyrum), ook wanneer deze met een andere dekvrucht mislukte. Naar de mening van de geciteerde Duitse schrijver zou dit vooral het geval zijn geweest op zeer droge zandgrond, waarop boekweit het beste groeide en de jonge klaverplantjes vocht en schaduw gaf.

Het fioringras (Agrostis alba) werd geteeld op nieuwe, goed gebrande en vochtige grond. Het groeide welig, scheen echter slechts als weidegras de toegekende lof te verdienen. Het Hollandse fiorin (in Duitsland windhalm geheten) groeide niet zo goed; ook te Frederiksoord liet men daarom planten uit Engeland komen. In vroegere geschriften was over dit gewas hoog opgegeven; deze waardering werd in de praktijk niet bevestigd. Het was mogelijk, dat men de cultuur van fioringras in de koloniën zou beëindigen, aldus Von Grouner.

De aardappelen werden op nieuw ontgonnen, geploegd en met de hak losgemaakt land gepoot door eerst met de schop op rijen gaten te steken, en hierin de poters te leggen met een handvol warme schapenmest. Op oude grond legde men de pootaardappelen „op de bekende wijze” na voorafgaande bemesting achter de ploeg in de voor. Indien nodig kreeg het gewas een overbemesting. Men overwoog te Frederiksoord aardappelen te laten volgen na tweejarige klaver en raaigras met een flinke bemesting.

Reeds in $1822 / 23$, toen de oudste kolonie (I) vier jaren in cultuur was, nam de Maatschappij hier een proef met enkele handelsgewassen, waartoe men vlas, winterraapzaad en wintertarwe rekende. Het winterraapzaad mislukte geheel, hetgeen aan de strenge winter werd toegeschreven. Dit gewas werd dan ook vervangen door zomerraapzaad ${ }^{03}$.

$\mathrm{Om}$ aan het hooigebrek tegemoet te komen dacht men aan een „ruimer teelt van mangelwortelen, zoo deze slagen, gelijk het zich laat aanzien". Uit deze mededelingen blijkt, dat Van den Bosch al gauw begon te experimenteren met gewassen, die in het voorgeschreven bouwplan niet waren opgenomen. 
De Utrechtse hoogleraar Jan Kops heeft in 1823 enkele vermeldenswaardige opmerkingen gemaakt over de gewassenkeuze ${ }^{104}$. Hij vond in het bijzonder de oudste koloniën I en II van belang, die respectievelijk 5 en 4 jaar in cultuur waren. De hoofgewassen rogge en aardappelen beoordeelde Kops op de meeste hoeven gelijk aan de stand op oude bouwlanden in de omgeving van de koloniën. Zelfs zag hij zeer goede percelen tarwe. Indien dit gewas tot de noodzakelijke behoeften der koloniën behoorde, niet meer mest nodig had dan rogge en voerstro van gelijke kwaliteit opleverde, kon men z.i. met de tarweteelt wel doorgaan. Uit deze zinsnede blijkt, dat Kops feitelijk sceptisch stond ten aanzien van de tarweproeven.

Ook het vlas deed het goed: het stond 4-5 oude voeten hoog. Daarom had Van den Bosch besloten jaarlijks 1/14 deel van elke hoeve met dit gewas te betelen.

Kops vond met name de rode klaver, die ook een goed gewas gaf, van veel belang. De kunstweide van raaigras en fiorin was eveneens van voldoende hoedanigheid. Als fiorin verbouwde men Agrostis vulgaris; het eigenlijke fiorin, Agrostis stolinifera, was niet te krijgen.

In het algemeen gaf Jan Kops in zijn verslag een gunstige beoordeling van het landbouwstelsel, zoals dit in de koloniën werd toegepast, al had hij op enkele ondergeschikte punten wel enige kritiek.

In 1824 maakte het Algemeen Verslag voor de eerste maal melding van de teelt van erwten in kolonie I. Naarmate de grond ouder werd en de bemestingstoestand zou verbeteren, dacht men meer handelsgewassen te verbouwen. In verband met de lage tarweprijzen had men in plaats van zomertarwe I mg gerst verbouwd, die een goede oogst beloofde.

Het Algemeen Verslag over I 826/27 noemt enige gewassen, die op de gronden van het Instituut voor den Landbouw te Wateren werden verbouwd. Van de voedergewassen gelukten klaver, rutabaga (of Zweedse rapen) en mangels minder goed. Spurrie en knollen deden het in Wateren beter.

In 1827 teelde men ook in de gewone koloniën, om in het tekort aan hooi te voorzien, "Mangelwortel (turnips) en Ruta-Baga (Zweedsche rapen), ook koolrapen genoemd, welke tot beestenvoeder in den winter gezaaid zijn en op vele plaatsen zeer goed voortkomen" 05 .

Dat de Maatschappij van Weldadigheid in de eerste jaren na de ontginning van de gronden meer moeilijkheden met haar teeltplan ondervond dan bij het opmaken van de plannen was voorzien, gaf zij toe in de weerlegging van de eerdergenoemde "Vlugtige waarnemingen". Zo was de proef met fioringras in het klein goed geslaagd, maar in het groot niet. 
Mede hierdoor waren belangrijke aankopen van hooi en mest noodzakelijk ${ }^{106}$.

Een geheel nieuwe vruchtwisseling voerde de Maatschappij in bij het besluit van 30 mei 1829 , dat was gebaseerd op een uitvoerige memorie, die Van den Bosch had samengesteld ${ }^{107}$. In dit gewijzigde vruchtwisselingsstelsel was een belangrijke plaats ingeruimd voor de bremcultuur, die in het voorgaande gedeelte van deze paragraaf is beschreven. Daar is ook vermeld, dat directeur Van Konijnenburg de aanwijzingen van de generaal gedurende diens afwezigheid slechts gedeeltelijk heeft opgevolgd.

De verhandeling, die Van den Bosch in 1836 heeft opgesteld ${ }^{08}$, bevat een afdeling, die onder de titel "Wijzigingen in het assolement" geheel is gewijd aan een hervorming van de vruchtwisseling. Naar zijn mening was de voordeligste algemene cyclus de volgende:

I. rogge met brem;

2. brem;

3. aardappelen.

Een zeer eenvoudig systeem derhalve, gebaseerd op de brembemesting. In verband met de omstandigheden en behoeften in de afzonderlijke koloniën waren echter variaties op deze algemene vruchtwisseling aan te bevelen.

Ten aanzien van de vrije koloniën ging Van den Bosch accoord met het voorstel van de directeur de gezinnen in twee categorieën in te delen, n.1. :

I. voor de landbouw ongeschikte gezinnen $( \pm \mathrm{r} / 3$ deel $)$;

2. voor de landbouw geschikte gezinnen ( $\pm 2 / 3$ deel).

De eerste groep moest „fabriekmatige arbeid” verrichten, voornamelijk aan de weefgetouwen, en zou zo nodig een toelage ontvangen. Zij moesten hun grond afstaan; deze werd zo regelmatig mogelijk verdeeld over de andere hoeven. Naar gelang van de omstandigheden zouden de z.g. „invalide" gezinnen worden verplaatst, zodat per sectie vier invalide en acht valide gezinnen zouden wonen.

Voor elke sectie van $42 \mathrm{mg}(=36 \mathrm{ha})$ stelde Van den Bosch de volgende vruchtwisseling vast, een variant op het reeds genoemde algemene systeem:

r. rogge, w.v. I I mg met brem, $3 \mathrm{mg}$ met klaver;

2. brem (I i $\mathrm{mg}$ ) en klaver ( $3 \mathrm{mg}$ );

3. aardappelen ( $8 \mathrm{mg})$, vlas ( $3 \mathrm{mg}$ ) en klaver $(3 \mathrm{mg})$. 
Naast eenjarige brem bleef tweejarige klaver in de vruchtwisseling opgenomen.

Het bouwplan bestond dus uit:

$33 \%$ rogge,

$26 \%$ brem,

$19 \%$ aardappelen,

$14 \%$ klaver en

$7 \%$ vlas.

Vergeleken met het voor I $83^{\circ}$ officieel van kracht zijnde teeltplan was derhalve de oppervlakte voedergewassen met ruim de helft verminderd, het areaal rogge met een derde gedeelte. De aardappel- en vlasteelt werden echter enigszins uitgebreid, terwijl de brem de resterende vrijgekomen grond in beslag nam. In verband met de geringe voederbouw verminderde men ook de veestapel tot één koe per voor de landbouw geschikt gezin.

In verband met de tussen de hoeven aanwezige greppels en wallen was het zonder veel kosten niet mogelijk het beschreven vruchtwisselingsstelsel geheel in te voeren per sectie op percelen van 3,8 en I I $\mathrm{mg}$. Daarom detailleerde Van den Bosch zijn systeem nader voor de beide categorieën hoeven ter grootte van $3 \frac{1}{2} \mathrm{mg}$ of 2 roo roeden $(=3 \mathrm{ha})$.

Voor de „invalide” hoeven (zonder koe) gold het systeem:

I. rogge met brem (j00 r);

2. brem (700 r);

3. aardappelen ( $700 \mathrm{r})$.

Dit was dus de algemene vruchtwisseling.

Voor de "valide" hoeven (met koe) moest men een ingewikkelder systeem volgen:

I. rogge, w.v. $475 \mathrm{r}$ met brem, $225 \mathrm{r}$ met klaver;

2. brem (475 r) en klaver (225 r);

3. aardappelen (250 r), vlas ( $225 \mathrm{r}$ ) en klaver $(225 \mathrm{r})$.

Op deze hoeven waren de percelen derhalve aanmerkelijk kleiner dan bij de „invalide” hoeven.

Een samentelling van de beide gedetailleerde bouwplannen in de verhouding van vier ,invalide" tot acht "valide" hoeven leidt tot de conclusie, dat per sectie op deze wijze inderdaad het hiervoor weergegeven bouwplan voor $42 \mathrm{mg}$ werd bereikt. Rekenkundig vormde de verhandeling van Van den Bosch dus een sluitend geheel. In verband met de onge- 
lijke oppervlakte van de percelen der „valide” hoeven en de wenselijkheid, dat alle percelen in de loop der jaren brem zouden dragen, behoeft het geen verwondering te wekken, dat de praktische toepassing van de beide voorgeschreven vruchtwisselstelsels een veel langduriger wisseling op de "valide" hoeven betekende dan een driejaarlijkse, waarbij moeilijkheden dan ook niet konden uitblijven.

Blijkbaar liet men de vlasteelt achterwege (zie ook bijlage 4). In een publikatie van de Maatschappij van I $84^{109}$ wordt een vijfjarig vruchtwisselplan opgegeven, waarin de klaver één- in plaats van tweejarig was :

I. rogge met brem;

2. brem;

3. aardappelen;

4. rogge met klaver;

5. klaver.

Deze vruchtwisseling vond toen plaats op vijf percelen van 0,6 ha. Het resulteerde in een bouwplan met:

$40 \%$ rogge,

$20 \%$ aardappelen,

$20 \%$ klaver en

$20 \%$ brem.

Op grond van de sinds 1840 teruglopende hooiopbrengst en toenemende hooiaankopen beval de directeur Van Konijnenburg in 1845 aan de Permanente Commissie een wijziging in de vruchtopvolging aan door de klaverteelt driejarig te maken ${ }^{100}$.

Deze verandering is naderhand ingevoerd. De bekende landbouwkundige Staring heeft namelijk in zijn rapport vermeld, dat in 1846 het volgende voorschrift in de gewone koloniën van kracht was :

$3 / 9$ rogge,

$2 / 9$ brem,

2/9 aardappelen,

$2 / 9$ haver of gerst met klaver en een-, twee- en driejarig klaverland.

Staring heeft aan de vruchtopvolging, de „hoofdzaak van allen akkerbouw”, een vijftal bladzijden van zijn rapport gewijd ${ }^{1 r}$. Het bovenstaande reglement ontwikkelend kwam hij tot een vruchtwisseling van niet minder dan $\mathrm{I} 8$ slagen (!), t.w.: 
x. rogge met brem;

2. brem;

3. aardappelen;

4. rogge;

5. haver of gerst met klaver;

6. klaver ;

7. klaver;

8. klaver;

9. rogge; ı . aardappelen;

I . rogge met brem;

I 2. brem;

1 3. rogge met brem;

I4. brem;

I 5. aardappelen;

I6. rogge met brem;

1 7. brem;

I 8. aardappelen.

Om het voorschrift volledig uit te voeren moest men dus de hoeven ter grootte van 3 ha verdelen in 18 percelen van $1 / 6$ ha. Staring noemde het terecht een onmogelijkheid dit systeem in de praktijk vol te houden.

Hij oefende dan ook tamelijk veel kritiek uit op de wijze, waarop de vruchtopvolging was geregeld. Degenen, die met de directe uitvoering waren belast, konden niet overzien, welk gewas op elke akker moest worden verbouwd in verband met de voorafgegane teelten. De opzichters maakte men "tot bloote werktuigen van degenen, welke van uit hun studeervertrek of bureau moeten bepalen, wat op dezen of genen akker geteeld behoort te worden". Men moest evenwel ook niet alles overlaten aan b.v. de onderdirecteuren voor de landbouw, "want dan zouden de bij alle Drentsche en Overijsselsche bouwlieden ingewortelde vooroordeelen welhaast alle vruchtafwisseling verbannen, te beginnen voorzeker met den Brem, en binnen weinig tijds zou men hier weder het jammerlijke drieslagstelsel ... zien heerschen".

Staring gaf de voorkeur aan een eenvoudiger vruchtopvolging van zes of zeven slagen als algemene regel, waarbij de adjunct-directeur voor de landbouw enige keus uit enkele gewassen kon doen overeenkomstig de weers- en bodemgesteldheid. Hij noemde een voorbeeld van een zesslagstelsel met $50 \%$ granen (dus meer dan in de koloniën) en een derde gedeelte voedergewassen in plaats van een zesde deel :

1. aardappelen of zomerknollen, zwaar gemest;

2. gerst of haver met klaver of raaigras of haver alleen;

3. klaver en raaigras of gemeste duivebonen of erwten;

4. rogge;

5. wortels, mangelwortels of koolrapen, zwaar gemest, of boekweit zonder mest;

6. rogge, haver of boekweit (na boekweit gemeste rogge).

Dit stelsel werd volgens Staring gevolgd op een bedrijf in Gelderland met lichte zandgrond. Hoewel de brem in dit systeem niet voorkwam, wilde 
hij hiermede niet zeggen, dat men deze teelt moest opgeven. Ook Staring was van mening, dat de bremcultuur in de koloniën zeer was aan te raden. Het was dan ook mogelijk om na de zesde slag van bovengenoemd voorbeeld een jaar brem in te voegen.

Reeds eerder is opgemerkt, dat de Permanente Commissie het rapport van de inspectiecommissie van 1846 , waarvan Staring deel uitmaakte, niet op de normale wijze wenste te publiceren als onderdeel van het Algemeen Verslag. Het bestuur van de Maatschappij reageerde in deze verslagen dan ook niet op Staring's kritiek op de vruchtwisseling en men mag derhalve aannemen, dat in het voorgeschreven systeem geen wijziging is gebracht.

Verdere aandrang tot veranderingen in de vruchtopvolging bleef echter niet uit. De inspectiecommissie uit de Commissie van Toezicht, die de koloniën in 1847 bezocht, beval de teelt van Engelse turnips en Zweedse rapen of knollen aan voor veevoeder. In de beantwoording van deze suggestie in het Algemeen Verslag over I 847 stelde de Permanente Commissie, dat de genoemde gewassen meermalen waren beproefd, maar niet hadden voldaan. Ook gewone knollen en spurrie mislukten niet zelden. Omdat de aardappelen en rogge nog onvoldoende opbrachten om de bevolking te voeden, gaf de Permanente Commissie aan deze gewassen de voorkeur, daar men veevoer goedkoper kon ankopen dan levensmiddelen voor de kolonisten.

Van Hall pleitte in 1848 voor dubbele cultures in één jaar, b.v. knollen of wortelen na of met rogge, kool na vroege knollen. Hoewel hij de brem niet met name noemde, kan men hieruit afleiden, dat de Groninger hoogleraar geen bewonderaar van deze teelt was: men kon deze nagewassen immers alleen op enigszins grote schaal verbouwen, als de bremteelt werd opgegeven of ingekrompen.

De Permanente Commissie nam aan, dat de dubbelcultures in ${ }_{n}$ de gewone zandstreken" meer voorkwamen dan in de koloniën. Echter achtte zij het "proefondervindelijk” bewezen, dat het niet raadzaam was deze in de koloniën meer toe te passen, dan toen het geval was wegens: a. het tekort aan arbeidskrachten om de nagewassen te zaaien ten tijde van de graanoogst en de uitzaai van het wintergraan; b. de extra bemesting, die meer zou kosten dan de waarde van het nagewas; c. de grote kans, dat de tweede cultuur zou mislukken.

Ook Van Hall's pleidooi voor meer vruchtwisseling in het algemeen legde de Permanente Commissie naast zich neer. De vruchtopvolging had reeds op doelmatige wijze plaats, hetgeen moest blijken uit het feit, dat de rogge-opbrengst in de koloniën niet achterbleef bij de gemiddelde 
opbrengst elders ${ }^{112}$. Men was overigens bereid te onderzoeken, in hoeverre meer vruchtwisseling mogelijk zou zijn.

Tenslotte schaarde ook directeur Van Konijnenburg zich in 1848 in het koor van de voorstanders van een gewijzigde vruchtopvolging. De oppervlakte groenvoer was te klein, terwijl het klaverland als kunstweide met vier jaren te lang werd aangehouden ${ }^{\mathrm{I}} \mathrm{3}$.

Ondanks alle goed bedoelde kritiek bracht het bestuur van de Maatschappij geen enkele verandering in het toegepaste systeem. In I 854 was nog hetzelfde "plan" van kracht als in I 846. Dit blijkt uit de toelichtende tekst bij de Staat van de te veld staande Gewassen in den zomer van I 854 , waaruit bijlage 5 is samengesteld. Hierin is niet opgenomen de in 1854 met brem beteelde oppervlakte, in de gewone koloniën 200,5 ha, te Wateren 13,4 ha, evenmin de grond in gebruik bij de 17 vrijboeren $(47,0 \mathrm{ha})$. Bovendien lag in dit jaar in de gewone koloniën $2,3 \mathrm{ha}$, te Wateren 4,6 ha braak. Het braakland was oud, hoog en afgelegen bouwland, dat niet kon worden bemest en werd afgeweid.

Bij de genoemde Staat is een vergelijking gemaakt tussen het teeltplan en de werkelijk bebouwde oppervlakten in de gewone koloniën. Deze luidt als volgt:

$\begin{array}{ll}\text { Volgens plan } & \text { In werkelijkheid } \\ 3 / 9 \text { winterrogge }=336,5 \text { ha, } & 3 \mathrm{I}, 3 \text { ha minder; } \\ \text { 2/9 aardappelen }=224,3 \mathrm{ha}, & \mathrm{I7}, 4 \text { ha minder; } \\ 2 / 9 \text { brem }=224,3 \mathrm{ha}, & 23,8 \text { ha minder; } \\ 2 / 9 \text { groenland }=224,3 \mathrm{ha}, & 72,4 \text { ha meer. }\end{array}$

Men had dus het areaal akkerbouwgewassen en brem met 8-10\% verminderd, waardoor bijna een derde meer groenland aanwezig kon zijn, dan geheel overeenkomstig het vruchtwisselplan het geval zou zijn geweest.

Bij wijze van proef verbouwde men in 1854 in kolonie $\mathrm{I}$ en in resp. 2,9 en 4, r ha Himalayagerst op aardappelgrond. Dit gewas, ook wel naakte gerst genoemd, werd als zomergraan gezaaid in plaats van winterrogge, indien men deze niet tijdig in de grond had kunnen brengen. Daar de proef goed gelukte, beval de directeur aan hiermee voort te gaan op leemachtige grond in de eerste wijken van kolonie I en III. Deze gerst werd als rogge in het brood verbakken ${ }^{114}$.

In onderstaande tabel volgt een overzicht van het teeltplan in 1857 . De totale oppervlakte cultuurgrond in dit jaar verschilde vrijwel niet van die in 1854 , zodat onderlinge vergelijking mogelijk is. 
Tabel 8 - BOUWPLAN IN I 857

\begin{tabular}{|c|c|c|c|c|c|c|c|c|}
\hline \multirow{3}{*}{ Kolonie } & \multicolumn{8}{|c|}{ Beteelde oppervlakte (ha) } \\
\hline & \multirow{2}{*}{$\begin{array}{l}\text { winter } \\
\text { rogge }\end{array}$} & \multirow{2}{*}{$\begin{array}{c}\text { aard- } \\
\text { appelen }\end{array}$} & \multirow[t]{2}{*}{ haver } & \multirow[t]{2}{*}{ boekweit } & \multirow[t]{2}{*}{ brem } & \multirow{2}{*}{$\begin{array}{l}\text { tuin- } \\
\text { grond }\end{array}$} & \multicolumn{2}{|c|}{ groenland $\mathbf{I}$} \\
\hline & & & & & & & kw. & bl. \\
\hline \multicolumn{9}{|l|}{ Gewone } \\
\hline koloniën & 290 & 208 & $x_{7}$ & 8 & 175 & 25 & 302 & I I \\
\hline Wateren & 20 & I 2 & 3 & 4 & 12 & I & 19 & 35 \\
\hline
\end{tabular}

I kw. = kunstweide, bl. = blijvend.

Bron: Staat der teveld staande Gewassen in den Zomer van 1857 .

Ten opzichte van 1854 blijkt vooral de oppervlakte brem te zijn verminderd, n.1. met $13 \%$ in de gewone koloniën en r $\%$ te Wateren. De vrijgekomen grond is voor een gering gedeelte gebruikt voor een lichte uitbreiding van het areaal granen (rogge, haver en boekweit), voor een groter deel voor de kunstweiden, althans in de gewone koloniën.

Toch werd ook in I 859 officieel nog steeds hetzelfde vruchtwisselingsplan gevolgd als in 1846 . Van Konijnenburg kwam tot de conclusie, dat de gehele vruchtwisseling een periode van $\mathrm{r} 8$ jaren omspande. Per hoeve van 2,7 ha bestond 2/9 deel of 0,6 ha uit kunstweide (klaver en gras), die 4-jarig was in die zin, dat jaarlijks $\frac{1}{4}$ deel of 0,15 ha werd gescheurd en eenzelfde oppervlakte kunstweide opnieuw ingezaaid, „hoedanige omgang, op zulk eene uitgebreide oppervlakte, met geene mogelijkheid door de ambtenaren behoorlijk is na te gaan, waarvan het gevolg is, dat er geen geregelde opvolging is verzekerd" 15 .

Naar de mening van Van Konijnenburg was de oppervlakte aardappelen en rogge te groot, bleef de kunstweide te lang liggen en was het vooral een bezwaar, dat $2 / 3$ van de rogge volgde op aardappelen, hetgeen een grote top in de arbeidsbehoefte betekende. Hij beval dan ook een aanmerkelijk eenvoudiger 6-jarig vruchtwisselstelsel aan met iets minder granen $(\mathrm{r} / 3 \mathrm{deel}), 25 \%$ minder aardappelen ( $\mathrm{r} / 6 \mathrm{deel}$ ) en 2 -jarige in plaats van 3 -jarige kunstweide. De oppervlakte groenland zou volgens het voorstel echter $50 \%$ groter zijn dan voorheen, $\mathrm{nl}$. 0,9 ha per hoeve. Ook aan de brem dacht Van Konijnenburg nog een plaats toe, evenwel onder de voorwaarde, dat dit gewas goed zou gelukken.

Samengevat kwam het plan van de aftredende directeur op het volgende neer: 
Tabel 9-DE BOUWPLANNEN IN DE GEWONE KOLONIZ̈N

\begin{tabular}{lrrrrr}
\hline & \multicolumn{5}{c}{ Percentage van de beteelde oppervlakte in } \\
\cline { 2 - 6 } & 1820 & 1822 & 1836 & 1840 & 1846 \\
\hline Regge & 25 & 50 & 33 & 40 & 33 \\
Gerst/haver & 25 & - & - & - & 6 \\
Aardappelen & 25 & 15 & 19 & 20 & 22 \\
Vlas & - & 5 & 7 & - & - \\
Groenvoeders & 25 & 30 & 14 & 20 & 17 \\
Brem & - & - & 26 & 20 & 22 \\
\hline & 100 & 100 & 100 & 100 & 100 \\
\hline Opp. van de & & & & & \\
kleinste percelen (ha) & 0,6 & 0,4 & 0,3 & 0,6 & 0,2 \\
\hline
\end{tabular}

Bronnen: zie de voorgaande tekst.

I. rogge met brem;

2. brem of boekweit;

3. aardappelen;

4. rogge of haver met klaver en raaigras;

5. klaver;

6. klaver.

Dit systeem heeft inderdaad verschillende voordelen vergeleken met het destijds toegepaste stelsel, zoals uit de voorgaande beschouwing is af te leiden. Van Konijnenburg besloot dan ook: "Mannen van het vak zullen, vlei ik mij, geen verdere aanprijzing van dit stelsel behoeven, om het boven het bestaande de voorkeur te geven."

Was Van Konijnenburg in de jaren rond 1830 geen voorstander van de door Van den Bosch gewenste invoering van de bremcultuur, men kan aannemen, dat hij omstreeks I 850 met de Permanente Commissie van mening verschilde over het bestaande vruchtwisselingsplan. Blijkbaar voelde het bestuur van de Maatschappij er niet voor zijn ideeën over het landbouwstelsel in de koloniën over te nemen en tot uitvoering te brengen. Het is dan ook waarschijnlijk, dat dit meningsverschil heeft bijgedragen tot het vertrek van Van Konijnenburg als directeur van de Maatschappij van Weldadigheid in I 859 onder gelijktijdige aanvaarding van de leiding over de sindsdien geheten Rijksopvoedingsgestichten te Veenhuizen.

Tot slot van deze uiteenzetting over de vruchtopvolging geeft tabel 9 een overzicht van de achtereenvolgens van kracht geweest zijnde bouw- 
plannen in de gewone koloniën. Duidelijk blijkt hieruit, van welk een grote invloed de invoering van de brembemesting is geweest op de oppervlakte groenvoedergewassen en rogge. Het bouwplan van 1846 is gehandhaafd tot I 859 , zoals hiervoor reeds is opgemerkt. Wel heeft de directeur in de praktijk enige kleine wijzigingen gebracht in de verhoudingen tussen de gewassen.

\section{c. De opbrengst der gewassen}

Uit de eerste jaren van de koloniën zijn vrijwel geen concrete gegevens bewaard gebleven over de opbrengst van de verbouwde gewassen. Het is de vraag, of men in de drukke aanvangsperiode van kolonisatie en ontginning wel voldoende tijd had om aandacht te besteden an een nauwkeurige bepaling of een taxatie van de stofopbrengsten. Voor de geschiedschrijving van de landbouw in de eerste helft van de Igde eeuw is het trouwens van meer waarde bekend te zijn met opbrengstcijfers betreffende bouwland, dat reeds enige jaren in cultuur was. Van de latere jaren zijn door de Maatschappij van Weldadigheid uitvoerige opbrengstgegevens verzameld in de oogststaten, t.w. vanaf het jaar $183 \mathrm{I}$. Ten dele zijn deze cijfers gepubliceerd in de Algemeene Verslagen.

Enkele jaren na de stichting van de koloniën in 1818 overtroffen de rogge- en aardappeloogst blijkbaar de eigen behoeften van de bevolking. In I $822 / 23$ ging men nl. het aardappelverbruik in de koloniën stimuleren in verband met de dalende prijzen ${ }^{116}$. Ook sprak men over de roggeprijs, die eveneens een dalende tendens vertoonde, zij het in mindere mate dan de aardappelprijs. Hieruit kan men afleiden, dat de Maatschappij aardappelen en rogge verkocht buiten de koloniën. De aardappelen slaagden dan ook het best op nieuwe gronden.

Ter vermeerdering van de eigen aardappelconsumptie ging de Maatschappij in de centrale bakkerij voortaan een mengsel van één deel roggemeel en drie delen aardappelmeel verbakken tot "roggebrood", dat naar de mening van de Permanente Commissie smakelijker, voedzamer en goedkoper was dan het zuivere roggebrood. Uit latere geschriften blijkt echter, dat de opvattingen over de smaak en voedingswaarde van het aardappelroggebrood uiteenliepen.

In het algemeen bereikte men op veenachtige grond in het tweede jaar een normale oogst, in het eerste jaar van cultuur $\pm 2 / 3$ gedeelte hiervan. Zandgronden zonder veen gaven in het eerste jaar ongeveer een halve oogst, in het tweede jaar $2 / 3$ en in het derde jaar een normale opbrengst. Op de z.g. magere leemgronden duurde het tot het vierde jaar, voordat 
men een gewone oogst verkreeg; in het eerste jaar brachten deze vrijwel niets op.

$\mathrm{Na}$ de beginjaren rekende de Maatschappij in $1822 / 23$ een matige opbrengst gemiddeld op 40 schepels rogge en $45^{\circ}$ schepels aardappelen per morgen, d.i. I 2 mud rogge en 136 mud aardappelen per $\mathrm{mg}$ of $990 \mathrm{~kg}$ rogge en II $200 \mathrm{~kg}$ aardappelen per ha ${ }^{17}$. Deze hoeveelheden zijn vanzelfsprekend aanmerkelijk kleiner dan de oogsten, die men tegenwoordig per ha zandgrond behaalt. Zo was de gemiddelde produktie van rogge per ha in de periode $1956 / 1960$ niet minder dan $2.892 \mathrm{~kg}$, van consumptieen voederaardappelen $26.300 \mathrm{~kg}^{118}$. Het uitgangspunt van $11.200 \mathrm{~kg}$ per ha voor een matige oogst in $1822 / 23$ in de koloniën is zeer waarschijnlijk nog aan de hoge kant.

Het Algemeen Verslag over I $824 / 25$ bevat de eerste gegevens over de werkelijke opbrengsten in de vrije koloniën. De rogge leverde $15 \mathrm{mud} / \mathrm{mg}$ op, de aardappelen $120 \mathrm{mud} / \mathrm{mg}$ en het boekweit $15 \mathrm{mud} / \mathrm{mg}$. De totale produktie achtte de Maatschappij voldoende om de exploitatiekosten te kunnen dekken. De oogst van rogge en aardappelen overtrof de behoefte met ruim $100 \%$, zodat de Maatschappij hiervan aan derden verkocht, veelal aan handelaren, die de winkelwaren voor de koloniale winkels leverden.

Hoewel cijfers niet worden vermeld, bevat het Algemeen Verslag over I 826/27 optimistische geluiden over de toenemende opbrengsten van de landbouw in de gewone koloniën. In de kolonie Willemsoord, die in vergelijking tot de andere steeds minder goede resultaten had gegeven, verkreeg men in 1827 voor de eerste maal op de gewone oppervlakte een aardappeloogst, die groter was dan de behoefte van deze kolonie ${ }^{I}{ }^{9}$.

De eerder aangehaalde anonieme schrijver verkondigde evenwel in 1828 , dat de opbrengsten van het land in de koloniën relatief laag waren. De rogge zou wel 90 schepels/mg kunnen opbrengen, d.i. bijna het dubbele van de in 1825 verkregen oogst, terwijl de aardappelen in de koloniën volgens hem slechts $\frac{1}{4}$ à $\mathrm{r} / 5$ opleverden van de opbrengst buiten de Maatschappij. Elders noemde hij als een normale roggeoogst in Drenthe en Friesland 80 schepels $/ \mathrm{mg}=24 \mathrm{mud} / \mathrm{mg}^{\mathrm{I20}}$.

In de jaren $1828 \mathrm{t} / \mathrm{m}$ I 830 had men te kampen met wateroverlast door langdurige regenval en met vroeg invallende vorst in het najaar ${ }^{21}$. De aardappelopbrengst bedroeg in de vrije koloniën in 1828 per $\mathrm{mg}$ 1 32-1 38 mud, in 1829 slechts 60 mud. Bovendien waren in enkele koloniën de aardappelen door zeer strenge vorst gedurende enige dagen in de eerste helft van november 1828 in de grond bevroren en was tevens de roggezaai vertraagd. Dit veroorzaakte een verlies van bijna $2000 \mathrm{mud}$ 
aardappelen in alle koloniën (incl. de gestichten), hetgeen de helft uitmaakte van de nog te velde staande aardappelen. De oogstwerkzaamheden waren dus zeer laat in de herfst nog niet beëindigd. De rogge bracht in 1829 in de gewone koloniën slechts $5,4 \mathrm{mud} / \mathrm{mg}$ op, terwijl men door de natte herfst en strenge winter in dit jaar niet meer dan $2 / 3$ van het roggeland kon inzaaien.

In $183^{\circ}$ was de aardappelopbrengst $\frac{1}{4}$ en de roggeopbrengst $\mathrm{I} / 3$ van de gemiddelde hoeveelheden van 1825 -I $827^{122}$. Men sprak dan ook in het Algemeen Verslag over I 829 van "buitengewone rampen”, die de landbouw hadden getroffen. Bovendien moest de Maatschappij aanzienlijke sommen besteden aan levensmiddelen en brandstof. Toch had men hoop dat de koloniën eenmaal in eigen onderhoud zouden voorzien.

Eveneens in 1829 gaf Wardenburg een schatting van de gemiddelde opbrengst van de zomer- en winterrogge in Drenthe en Overijssel over een periode van tien jaren ter grootte van $20 \mathrm{Ned}$. mudden/ha, d.i. \pm I $7 \mathrm{mud} / \mathrm{mg}^{\mathrm{I23}}$, dus betrekkelijk veel lager dan de elders door hem genoemde $24 \mathrm{mud} / \mathrm{mg}$. Maar ook wanneer men de laagste schatting als vergelijkingsmaatstaf hanteert, is het duidelijk, dat de opbrengst in de koloniën omstreeks $x 29$ bepaald slecht was.

Dat het hier inderdaad uitzonderlijk geringe oogsten betrof, blijkt wel uit de jaarlijkse opbrengstcijfers vanaf $183 \mathrm{I}$, zoals deze zijn opgenomen in de oogststaten. Bijlage 6 geeft hiervan een overzicht voor de gewone koloniën tezamen en Wateren.

Uit deze jaarcijfers is af te leiden, dat de roggeoogst in de gewone koloniën alleen in 1847 de eerdergenoemde opbrengst van $20 \mathrm{mud} / \mathrm{ha}$ opleverde. Te Wateren bracht de rogge doorgaans betrekkelijk veel meer op dan in de gewone koloniën. Dit was aanvankelijk ook met de aardappelen het geval. Vanaf I 84I was de aardappeloogst te Wateren echter steeds kleiner dan die in de gewone koloniën.

Het verloop van de opbrengstcijfers sedert ${ }_{1} 8_{3} I$ is duidelijker af te lezen uit tabel 10 , die vijfjaarlijkse gemiddelden weergeeft voor de beide belangrijkste gewassen rogge en aardappelen. De gemiddelden zijn niet gewogen en berekend uit bijlage 6 .

De opbrengst van de rogge vertoont vanaf $\mathrm{I} 83$ I een onregelmatige lijn in die zin, dat de gemiddelde oogst per ha in de gewone koloniën in de jaren $1851-1857$ ongeveer $10 \%$ groter was dan in $1831-1835$. Te Wateren bedroeg dit verschil ruim 1 $2 \%$. De aardappelopbrengst echter bereikte in de gewone koloniën in de jaren 1841 - 1845 een hoogtepunt om vervolgens, vooral door de aardappelziekte, af te nemen tot een niveau, dat na 1845 gemiddeld lager lag dan vóór I 835 . Bij het Instituut 
Tabel IO-OPBRENGST VAN ROGGE EN AARDAPPELEN I83 I-1857

\begin{tabular}{|c|c|c|c|c|}
\hline \multirow{3}{*}{ Periode } & \multicolumn{4}{|c|}{ Gemiddelde opbrengst in mud/ha van } \\
\hline & \multicolumn{2}{|c|}{ rogge } & \multicolumn{2}{|c|}{ aardappelen } \\
\hline & gewone koloniën & Wateren & gewone koloniën & Wateren \\
\hline $1831-35$ & I 2,3 & I7,4 & 179 & 197 \\
\hline $1836-40$ & $\mathbf{1 4 , 4}$ & 23,8 & 205 & 217 \\
\hline $184 I-45$ & I 2,8 & 17,2 & $2 \times 2$ & 150 \\
\hline$x 846-50$ & 14,3 & 18,9 & $\mathbf{1 4 5}$ & 93 \\
\hline $1851-57$ & $r_{3}, 4$ & 19,6 & 136 & 99 \\
\hline
\end{tabular}

Bron: oogststaten.

te Wateren vielen de grootste aardappeloogsten in de jaren $1836-1840$. De latere daling was hier veel sterker dan in de gewone koloniën: in I 846-I 850 verkreeg men slechts $43 \%$ van de opbrengst van I 836-I 840 !

Directeur Van Konijnenburg constateerde in 1859 dan ook terecht, dat de vruchtbaarheid van de grond gering bleef door het zoeken naar het beste landbouwstelsel ${ }^{\mathrm{r} 24}$. Vergelijkbare goede zandgrond in de omtrek van de gewone koloniën bracht naar zijn mening in $\mathrm{I} 859$ bij een redelijk goed gewas 23 mud rogge per ha op. De arbeid van de kolonisten was dus onvoldoende produktief, aldus Van Konijnenburg, hoewel men het volle zaaizaad van bijna 3 mud per ha aanwendde. Dit bracht in de koloniën slechts het vier- tot vijfvoudige op in plaats van het achtvoudige.

Deze opvattingen van Van Konijnenburg zijn eerst in I 859 gepubliceerd. Hetgeen de Maatschappij voordien in de openbaarheid bracht, getuigt van een grote mate van optimisme ten aanzien van de ontwikkeling van de agrarische produktie in de koloniën, zodat men in de officiële publikaties waarschijnlijk slechts zelden een juiste, objectieve weergave van de feitelijke situatie aantreft. Wanneer men hierin al een uiting van ontevredenheid vindt over de opbrengst van de gewassen, dan is deze altijd wel gekoppeld aan een verklaring, die de oorzaak legt bij factoren, waarop de Maatschappij zelf weinig of geen invloed kon uitoefenen.

Zo stelde de Permanente Commissie in de Berigten uit de koloniën over de maand Augustus $183^{125}$, dat de rogge voorspoedig was binnengehaald en men tevreden was over de oogstcijfers, geraamd aan de hand van het gedeeltelijk afdorsen, hoewel „de oogst nog gering is bij een gewoon goed roggegewas van deze gewesten". Een opbrengst van 16 mud/mg zou het "toppunt van volkomenheid" zijn. Ook de uitkomsten 
van de aardappelteelt noemde men in $183^{\mathrm{r}}$ "redelijk en gezegend" ${ }^{26}$. In de gewone koloniën was de opbrengst driemaal zo groot als in i 830 .

Bij de door hem opgestelde oogststaten gaf de directeur evenwel af en toe een kritische beschouwing, die de indruk wettigt, dat deze voor intern gebruik bedoelde geschriften de werkelijkheid meer weerspiegelden dan de publikaties.

Om de aardappeloogst te vergroten gebruikte de Maatschappij in $\mathrm{I} 832$ nieuwe poters, meest Bremers, die veel op de Rademakers geleken, en ook Engelse. Zij hadden uitmuntend voldaan. Te Wateren was de stijging van de opbrengst te danken aan de goede behandeling van de grond en de uitbreiding van de veestapel. „Ook dit etablissement kan, zoo voortgaande, weldra bloeyend heten en in de ruimte afleveren de rente, die deszelfs verbetering gekost heeft" 127 .

Voor de vlasverbouw gebruikte men Rigazaad (uitzaai 2 mud/mg) en ook Revelaar en Revelaarskind (resp. eerste en tweede nabouw in Nederland). De gemiddelde opbrengst in kolonie I bedroeg in 1832 per Rijnlandse mg 334 pond vlas. Een matig gewas kon op geschikte grond echter wel 600 pond opleveren ${ }^{\mathrm{I} 28}$.

In zijn commentaar op de roggeoogst schreef Van Konijnenburg in dit jaar : „In weerwil dier onmiskenbare vooruitgang moet de oogst nog gering heten, al slechts de helft bedragende van hetgeen de grond ligtelijk opleveren kan." Als oorzaken noemde hij :

I. de nog te geringe bemesting;

2. de veenachtige losheid van de grond in de 3 de wijk van kolonie I en de iste en 2 de wijk van kolonie II;

3. het vele onkruid, vooral kweek;

4. de minder zorgvuldige bewerking.

De directeur beval aan de veengrond te bezanden, overigens veel te spitten tegen het onkruid en meer te bemesten, desnoods op een kleinere oppervlakte roggeland. Z.i. was zeker I $2 \mathrm{mud} / \mathrm{mg}$ mogelijk ${ }^{129}$.

In het volgende jaar ( 1833 ) bracht de rogge op vele plaatsen buiten de koloniën meer dan $3 \circ \mathrm{mud} / \mathrm{ha}$ op. Weliswaar was dit een buitengewoon rijke oogst, maar in de gewone koloniën kwam men tot niet meer dan I $5 \mathrm{mud} / \mathrm{ha}$. Om de onderdirecteuren en wijkmeesters tot meer ijver aan te sporen bepaalde de Maatschappij, dat hun geschiktheid voornamelijk zou worden getoetst aan het welslagen der gewassen ${ }^{130}$.

Te Wateren vond dit jaar een tweede proef plaats met zomerkoolzaad op drassige, gebrande veengrond, die 15 mud zaad opbracht van 2 ha. Doordat de grond pas laat kon worden gebrand, moest men het zaad te 
laat zaaien, zodat het gewas niet geheel kon rijpen. Niettemin was deze proef beter geslaagd dan die van $183^{2^{13 x}}$.

De geringe opbrengst van de meeste gewassen in 1834 hing samen met de langdurige droogte in dit jaar ${ }^{\mathrm{I}} \mathbf{2}$.

Het was voor de Maatschappij van Weldadigheid uiteraard van groot financieel belang te trachten de agrarische produktie op een dusdanig peil te brengen, dat aan de behoeften van de bewoners der koloniën kon worden voldaan. Dat dit bij de in het algemeen geringe opbrengsten en de dichte bevolking (een ongunstige „man-land ratio”) een moeilijke opgave was, blijkt uit de situatie in 1836 , toen de oogst aan aardappelen en rogge relatief groot was (bijlage 6 en tabel ro). Hoewel de gerooide hoeveelheid aardappelen voldoende was om de behoefte te kunnen dekken, was dit bij de rogge geenszins het geval. In de gewone koloniën bedroeg in dit jaar de benodigde hoeveelheid rogge (totaal verbakken) 2848 mud. De eigen produktie beliep slechts 1656 mud, d.i. $58 \%$. Deze kon de Maatschappij intern aanvullen met 88 mud uit Wateren en 300 mud uit de Ommerschans, zodat men nog 804 mud moest aankopen ${ }^{133}$.

Door een grote uitbreiding te geven aan de oppervlakte rogge in de gewone koloniën ( $1836:$ r 84 ha, $1837: 269$ ha) gelukte het in 1837 aan de vraag naar rogge te voldoen. De totale produktie (incl. 9 vrijboeren) bedroeg $4.031 \mathrm{mud}$ en overtrof de behoefte met $43^{\circ} \operatorname{mud}^{134}$.

Het areaal aardappelen was eveneens iets vergroot (met 2 I ha) door de tuinen voor eigen gebruik van de kolonisten te verkleinen. Daar de opbrengst per ha in 1837 echter relatief gering was, bedroeg de totale produktie (incl. vrijboeren) niet meer dan 24.895 mud, na aftrek van poters 21.000 mud tegen een behoefte van $33.000 \mathrm{mud}$. In de gewone koloniën was dus een tekort van 12.000 mud aardappelen, terwijl in Wateren de opbrengst ongeveer overeenkwam met de behoefte. Hier werd op bijna $3 \mathrm{mg}$ een proef genomen met het zorgvuldig afplukken van de bloemen op de ene helft van het perceel; op de andere helft liet men de aardappelplanten normaal doorbloeien. Bij overigens gelijke behandeling was geen opbrengstverschil te constateren, „zoodat de gunstige meening van sommigen dier handelwijze, bij ons nog wordt in twijfel getrokken", aldus Van Konijnenburgi 35 .

Inmiddels was in 1836 de brembemesting op grote schaal ingevoerd. Westendorp Boerma zegt over de gevolgen van de bremcultuur voor de opbrengst der gewassen: „Er woei weer een nieuwe wind door de koloniën. De toestand van de velden verbeterde zienderogen en de oogsten werden jaar op jaar fraaier"1 36 . Hij merkt evenwel tevens op, dat de oogsten in de gewone koloniën geheel achteraan kwamen, maar 
langzamerhand weer ophaalden. Uit de opbrengstcijfers van bijlage 6 krijgt men echter de indruk, dat de roggeoogst in de gewone koloniën en te Wateren in de jaren na 1836 tot 1847 vrijwel niet toenam. Wel is tot en met 1844 , althans in de gewone koloniën, een vergroting van de aardappelopbrengst per ha te constateren, die het gevolg kan zijn geweest van de brembemesting.

De winterrogge leverde op veenachtige grond, zoals in de derde wijk van kolonie I en in kolonie II, minder op dan zomerrogge. Van Konijnenburg kwam tot het besluit, „dat op ligten of lossen veenachtigen grond beter zomer- dan winterrogge wassen wil" ${ }^{137}$. Niettemin verbouwde men in de gewone koloniën in 1839 slechts 9 ha zomerrogge tegen 192 ha winterrogge ${ }^{138}$.

Om de aardappeloogst te verruimen nam de Maatschappij in $183^{8}$ een proef in kolonie I op 5,3 $\mathrm{mg}$ grond met een ander ras, de z.g. kromhouten. Het resultaat was niet voordeling: $133 \mathrm{mud} / \mathrm{mg}$. Het volgende jaar werd deze proef herhaald met kromhouten uit de omgeving van Leiden. $\mathrm{Zij}$ voldeden deze keer matig. Een derde proefneming in 1840 te Willemsoord leverde weliswaar $209 \mathrm{mud} / \mathrm{mg}$ op, maar dit was relatief weinig ten opzichte van $68 \mathrm{mg}$ gewone aardappelen na uitsluitend brembemesting $(226 \mathrm{mud} / \mathrm{mg})$. De teelt van kromhouten wilde men toch voortzetten in verband met de bijzonder goede en fijne smaak ${ }^{139}$.

Eveneens in I 840 nam men een proef met het afmaaien van zeer geil aardappelloof op één voet hoogte. Het bleek echter, dat dit geen aanbeveling verdiende. Daar de totale aardappeloogst in de vrije koloniën in dit jaar groter was dan de behoefte, kon men 4719 mud afleveren aan de gestichten te Veenhuizen.

Ook de roggeoogst overtrof de behoefte, zowel in de gewone koloniën als te Wateren. $184^{\circ}$ was dus een relatief gunstig jaar. Uit de in de oogststaten vermelde opbrengstcijfers per wijk volgt de conclusie, dat zowel rogge als aardappelen tot en met r 836 het meest opbrachten in kolonie I, met name in de eerste en tweede wijk (Frederiksoord), het minst in kolonie II (Wilhelminaoord), vooral in de 3 de wijk, terwijl kolonie III (Willemsoord) doorgaans een tussenpositie innam. Vanaf 1837 gaf echter kolonie m de grootste roggeoogsten, wat eveneens in de meeste jaren het geval was met de aardappels. Het aanvankelijk minder gunstig beoordeelde Willemsoord ging na 20 jaren de beide andere koloniën overvleugelen in produktiviteit. In $184^{\circ}$ leverde zelfs kolonie II per $\mathrm{mg}$ meer rogge dan I, maar dit was slechts incidenteel. In de gewone koloniën was de oogst het vijfvoudige van het zaaizaad, te Wateren het acht- 
voudige. De zomerrogge mislukte opnieuw, zodat Van Konijnenburg besloot dit gewas niet meer te verbouwen ${ }^{\mathrm{I} 40}$.

Behalve rogge en aardappelen was ook de haverteelt van enig belang. In 1843 besloeg deze in de gewone koloniën $40 \mathrm{mg}$. De opbrengst was 501 mud groter dan de behoefte aan zaaizaad (4 mud/mg) en paardenvoer door een oogst van bijna 2 I mud/mgin ${ }^{14}$.

De roggeoogst was in 1843 weer groter dan de behoefte aan broodgraan en zaaizaad $(2,4 \mathrm{mud} / \mathrm{mg})^{\mathrm{I} 42}$. De opbrengst van de aardappelen was in dit jaar in de gewone koloniën beter dan ooit tevoren (2 8 mud/ $\mathrm{mg}$ ), in verhouding tot de hoeveelheid pootgoed van 23,6 mud/mg meer dan het negenvoudige. Men had een overproduktie van 7512 mud. Een "vol gewas" stelde Van Konijnenburg op $200 \mathrm{mud} / \mathrm{mg}$. Deze hoeveelheid was in 1843 voor de eerste maal (in I 844 voor de laatste maal!) overschreden. Te Wateren gebruikte men nooit meer dan 18 mud pootaardappelen per mg, zodat de opbrengst daar ruim het tienvoudige bedroeg (bijlage 6). Als vroege aardappelen verkoos de directeur de negenwekers, als "volgers" de zomer-Engelse en als winteraardappelen de Rademakersi43.

In het algemeen was 1843 ten anzien van de opbrengst van de landbouw het topjaar van de periode i 8 1 8-1859. De directeur gaf bij deze gelegenheid een uitvoerige beschouwing en een optimistische toekomstvisie $^{144}$. Hij verbond hieraan een overzicht van de "ruwe opbrengst" in de afzonderlijke en gezamenlijke koloniën, dat een duidelijk beeld geeft van de uiteenlopende agrarische bedrijfsstructuur (tabel II). Hierin is de bruto geldopbrengst in verband gebracht met de oppervlakte cultuurgrond, de gebruikte hoeveelheid mest en het aantal inwoners (excl. de ambtenaren en hun gezinsleden).

Tabel II - BRUTO OPBRENGST VAN DE LANDBOUW IN I 843

\begin{tabular}{|c|c|c|c|c|c|c|c|}
\hline Kolonie & $\begin{array}{l}\text { Bruto } \\
\text { opbr. in } \\
\text { guldens }\end{array}$ & $\begin{array}{l}\text { Opp. } \\
\text { cult.- } \\
\text { grond in } \\
\text { mg }\end{array}$ & $\begin{array}{c}\text { Bruto } \\
\text { opbr. in } \\
\text { guld./ } \\
\text { mg }\end{array}$ & $\begin{array}{c}\text { Voeren } \\
\text { mest }\end{array}$ & $\begin{array}{c}\text { Bruto } \\
\text { opbr. in } \\
\text { guld./ } \\
\text { voer }\end{array}$ & $\begin{array}{l}\text { Aantal } \\
\text { zielen }{ }^{I}\end{array}$ & $\begin{array}{c}\text { Bruto } \\
\text { opbr. in } \\
\text { guld./ } \\
\text { hoofd }\end{array}$ \\
\hline Gewone koloniën & 114.547 & 959 & II9 & 36.961 & 3,10 & 2.495 & 46 \\
\hline Wateren & 8.366 & 108 & 77 & $3 \cdot 37 \mathrm{I}$ & 2,48 & 72 & 116 \\
\hline $\begin{array}{l}\text { Alle koloniën } \\
\text { (incl. gestichten) }\end{array}$ & 325.603 & 2.931 & III & I 1.937 & 2,91 & 10.233 & 32 \\
\hline
\end{tabular}

I Alleen de kolonisten en gezinsleden.

vet = het grootst van alle koloniën incl. de gestichten te Veenhuizen en cursief $=$ het geringst van alle koloniën $\}$ Ommerschans.

Bron: Algemeene Oogststaat van 1843 . 
Het blijkt, dat de landbouw in de gewone koloniën per mg het meest opleverde, te Wateren het minst (in geld uitgedrukt). Bij het Instituut te Wateren gebruikte men per mg ook relatief weinig mest, terwijl de vruchtbaarheid van de grond hier sinds I 84I achter was gebleven. Ook per voer mest was de bruto opbrengst te Wateren naar verhouding gering. Doordat het aantal zielen per $100 \mathrm{mg}$ te Wateren (67) relatief zeer klein was (in de gewone koloniën 260 zielen/roo mg), was de bruto opbrengst per hoofd te Wateren echter het hoogste van alle koloniën. Men kan stellen, dat de „arbeidsproduktiviteit” te Wateren 2,5 maal zo groot was als in de gewone koloniën.

In de herfst van I 844 zou in alle koloniën (incl. de gestichten) \pm 800 ha rogge worden uitgezaaid, „die, bragt ze, even als de aardappelen, een vol gewas voort, zoo als in Drenthe in der daad gemiddeld verkregen wordt, niet minder dan 19.000 Mud moest opleveren, tegen 24 Mud van het bunder, of 7 -voud van het gezaaide" ${ }^{145}$. Ten aanzien van de roggeteelt maakt het Algemeen Verslag over 1844 tevens melding van een proef met rijenteelt op 72 roeden, die tegen $14 \mathrm{mud} / \mathrm{ha}$ opbracht.

De feitelijke roggeoogst in $\mathrm{r} 845$ bedroeg niet meer dan $14,6 \mathrm{mud} / \mathrm{ha}$ (gewone koloniën); de bovengenoemde normale hoeveelheid van 24 $\mathrm{mud} / \mathrm{ha}$ is in deze koloniën in de periode tot en met 1857 nooit bereikt (bijlage 6). Over de zaaizaadhoeveelheid, zo schreef de directeur, „is men het thans in de koloniën eens geworden": 2,8 mud/ha tot I 5 oktober $3 \mathrm{mud} / \mathrm{ha}$ van 15 oktober tot ${ }_{5} 5$ november, hierna $3,2 \mathrm{mud} / \mathrm{ha}^{146}$. Naar hedendaagse begrippen zijn dit grote hoeveelheden. In verband met de rijenteelt zaait men tegenwoordig in het algemeen niet meer dan 2 $\mathrm{mud} / \mathrm{ha}$. Wat de voorvrucht betreft, had de ondervinding in de koloniën geleerd, dat voor de roggeteelt niets beter was dan gescheurd groenland, zoals bremgrond voor de aardappelen.

Laatstgenoemd gewas is in 1845 voor de eerste maal getroffen door de gevreesde aardappelziekte, "de bekende ramp der aardappelen", zoals het Algemeen Verslag zegt. Het gevolg was, dat de aardappeloogst in I 845 per ha nog niet de helft bedroeg van de opbrengst van het voorgaande jaar (die de grootste was in de geschiedenis van de Maatschappij). Van Konijnenburg heeft een tamelijk uitvoerige beschrijving opgesteld van de ziekte en haar verschijnselen ${ }^{147}$, die tevens een goed beeld geeft van de destijds levende gedachten over de mogelijke oorzaken. Na de geringe opbrengst te hebben genoemd, vervolgde de directeur:

„Hoe treurig en hoogst schadelijk deze uitkomst ook zij; bemoedigend (sic) is het daarbij te weten, dat het misgewas der aardappelen zoo algemeen, niet alleen over ons land, maar over geheel Europa, voor zoo 
verre er de aardappel verbouwd wordt, verspreid is, dat daarvan geen voorbeeld bestaat, zoo lang dit voedsel in ons werelddeel wordt geteeld. -Zelfs zou de zoogenoemde aardappelziekte ook in Amerika zijn waargenomen. Geen wonder dan, dat de gansche wetenschap er op uit is, de aanleidende oorzaak van deze verschrikkelijke ramp, waarvan de gevolgen nog niet te overzien zijn, optesporen, en nogtans lopen de gevoelens hierover zóó uiteen, dat men van de waarheid nog zeer verre verwijderd schijnt. Intusschen komen de waarnemingen, gevolgtrekkingen en oordeelvellingen in de Koloniën en van den Ondergeteekende hierop neder :

"Het is waar, de vorige winter heeft, van het begin van December tot in het laatst van Maart en dus 5 maanden ${ }^{148}$, zeer lang geduurd, zoo dat men eerst met half April is begonnen te poten; doch die voorafgaande koude kan de bedoelde oorzaak niet geweest zijn, daar juist de vroeg rijpe hun wasdom hebben bekomen en de later gepoote niet.- Nog vóór Juny was de poting overal in de koloniën afgelopen. Die vruchtbare maand deed het aardappelengewas voordeelig staan; in de koloniën nog gunstiger dan ooit te voren, doordien er nog nimmer zoo veel op eene beste brembemesting gepoot waren, waaraan de in het oog loopende vooruitgang in den kolonialen aardappelbouw, gedurende de laatste jaren, te danken was.- In het begin van July, terwijl er nog al veel regen viel, stonden de planten dan ook zoo geil, als ooit gezien was.- Daarop vielen den 3 e en vervolgens den $7 \mathrm{e}$ voorbeeldloos heete dagen in, dat de thermometer tot 92 graden klom, eene hitte, die spoedig bleek, door dit gewas niet te kunnen worden wederstaan ${ }^{149}$. Reeds werd er toen, door sommigen, opgemerkt dat de aardappelen in hunnen groei scheenen stil te staan en nog geene maand daarna, waarin het weder koel en vochtig was, verspreide zich de mare der aardappel-ziekte, die achtereenvolgende overal werd opgemerkt, met dit onderscheid, dat de aardappelen op de kleien leemgronden of op zulke gronden, welke door veel teelstof het vruchtbaarst waren, meer of minder tot verrotting overgingen, terwijl die op zand- en veengronden, op schralen en op nieuw aangemaakte gronden geteeld, slechts de eerste sporen van de ziekte, in eenige donkere vlekken droegen. Maar overal bleek het dat de aardappel in zijnen groei was gestuit; verdere aandoening en verrotting stond in verband tot de meerdere vruchtbaarheid van den grond. Later is het gebleken, dat de gevlekte aardappel ligtelijk uitloopt, dat het bewijs oplevert voor die plotselinge stuiting van den groei, daar de aardappel, die men vergeet te rooyen, niet voor na den winter en dus na de groei geheel opgehouden heeft, opslaat. De aardappelziekte zou aldus niets anders wezen, dan dat de 
vermelde hitte het climaat ongeschikt gemaakt heeft voor deze plant, hetzelve als dat men de aardappelen in eene broei-kast bij zulk eenen graad van hitte, wilde teelen, waarom het van belang schijnt te wezen, na te gaan, of die hitte niet overal en evenzeer is waargenomen, daar waar zich de aardappelziekte geopenbaard heeft. Voor herhaling van deze ramp zou dan ook geen meer vrees bestaan, als hetzelfde zeldzame heete weder onder deze luchtstreek te verwachten is en de overgebleven goede, ja zelfs min of meer gevlekte aardappelen, maar waarin niettemin de kiem reeds gebleken is bewaard te zijn, zullen, op zijn tijd gezet, hoogst waarschijnlijk, even goed ontspruiten, wassen en goede vrucht voortbrengen als eertijds. Veel minder behoeft er gedacht te worden aan een of ander bederf in den grond, die zich vervolgens, weer aan den aardappel of ook aan andere vruchten zou doen kennen.-" Aldus de uiteenzetting van directeur Van Konijnenburg van december r 845 .

De schade, die de Maatschappij opliep door de aardappelziekte, was aanzienlijk. Ter tegemoetkoming schonk de regering in I 846 een bedrag $\operatorname{van} f 80.000$, - 150 .

Ook in dit jaar trad de aardappelziekte op, zij het met minder ernstige gevolgen dan in I 845. Wederom was er begin juli een periode van aanhoudende, felle droogte, niet zo sterk als in 1845 , maar wel van langere duur. Na deze warmte stagneerde de groei van de aardappelplanten opnieuw. Naarmate de aardappels later waren gepoot, leverden zij ook minder op.

De directeur zei hierover het volgende: „Geen soort van aardappelen, - geen bijzonder land noch voorafgegane beteling van hetzelve is gebleken voor die ziekelijke aandoening te beveiligen; zelfs de planten onmiddellijk van buitelandsch zaad voortgekomen, zijn evenzeer door de ziekten getroffen geworden. Het schijnt derhalve dat de hitte zekere ongunstige gesteldheid van den grond opwekt en de aardappelen-ziekte veroorzaakt, die intusschen, dit jaar reeds aanmerkelijk minder hevig was, dan het jaar te voren, zoodat er, maar weinig aardappelen tot bederf zijn overgegaan en de vrucht, in het algemeen, ook grooter en beter van smaak geworden is, waaruit kan worden afgeleid, dat dezelve weldra geheel zal verdwijnen, hetgeen voor het geheele Vaderland en vele andere Rijken, zoo wel als voor de Koloniën, eene aller gewenschte zaak zoude zijn"15 .

In zijn toelichting op de Algemeene Oogststaat van 1846 sprak Van Konijnenburg zich over de mogelijke oorzaak van de aardappelziekte nader uit: ,,Ontwikkeling, door de hitte, van in den grond aanwezigen voor den aardappel schadelijke stof- misschien door vroegere vochtigheid ontstaan, schijnt onzes oordeels de oorzaak van de ziekte." 
Ook de rogge bracht in 1846 zeer weinig op; in de gewone koloniën en te Wateren was de opbrengst de laagste van de gehele periode I 83 2-I 857 (bijlage 6). Deze tegenslag werd eveneens veroorzaakt door een ziekte, die de directeur als volgt beschreef:

„De oorzaak van het geringe verbouw van dit jaar is voornamelijk geweest de roest, of de aan de rogge ontdekte algemeene ziekte, welke de roggeteelt, naar het oordeel van den landman, voor de helft heeft doen mislukken. Die ziekte heeft zich aldus vertoond. De zaai-tijd is vrij gunstig geweest, en de winter was zeldzaam zacht, genoegzaam zonder enige vorst, en in February was het weder zelfs zoo vruchtbaar, dat de rogge-planten sterk waren opgegroeid en uitgestoeld, zoo dat er de aren schenen te zullen uitkomen. Hierop volgde, in Maart tot in April, zoo veel vochtigheid en koud weder, dat het schoone groen verdween en de rogge zoo achterlijk maakte als maar zeldzaam gezien was. Toen, vervolgens, in Mei de planten weer begonnen op te schieten en in de aren kwamen, werd het blad der halmen geel, als met een fijn poeder overdekt. Het drooge weder in Juny deed die geelheid langzaam verdwijnen, maar de plant bleef ziekelijk, daar de bloesem niet dan traag en moeyelijk uitkwam, en er wel stukken waren, die, inplaats van twee, meer dan vier weken bloeiden. Daarna ontdekte men, aan de meeste aren, tot in de zaadcellen, gelijk geel-roode stof, die de groei des korrels verhinderde. Daarbij waren de aren holvakkig, of slecht geladen en veel warmte en droogte deed het graan zeer vroeg rijpen. - Of nu deze ziekte veroorzaakt is door die vochtigheid en koude, gevolgd op het zachte winterweder; of van op de planten gevallen honig-douw, waarvan ik het eerste zou gelooven, de uitkomst was, in alle gevallen noodlottig en schijnt het over een groot gedeelte van Westelijk Europa te wezen, daar de prijs der rogge, - zeker ook ten gevolge van eene vernieuwde gedeeltelijke mislukking van den aardappelbouw, tot over de $f 9,-$ het mud is gestegen en er in de koloniën, alwaar maar $2 \frac{1}{2}$ maal het zaai-zaad gewonnen is, niet minder dan 7122 mud voor de brood-bakkerijen zal te kort komen, wanneer men 2 en 3 mud aardappelen tegen $r$ mud rogge zal kunnen blijven verbakken"152.

De marktprijs van rogge was normaal $f_{5}$, -, van aardappelen $f_{\mathrm{I}}$, per mud. Een hoeveelheid brood met een mengverhouding van I op 3 mud kostte dus in gewone tijden $f 8$, - . In $1846 / 47$ kon men in de koloniën echter alleen rogge verbakken, waarvan de prijs in april 1847 per mud $\pm f$ r 4,75 bedroeg. Daar het meel van 3 mud aardappelen gelijk werd gesteld met I mud roggemeel, kostte eenzelfde hoeveelheid brood, uiteraard van een betere samenstelling, toen niet minder dan $\pm f 29,50$, 
d.w.z. meer dan $3 \frac{1}{2}$ maal zo veel153. Daarom verleende de regering de Maatschappij ook in 1847 een subsidie, deze keer ten bedrage van $f_{1} 61.586,59$, ter tegemoetkoming in de buitengewone uitgaven. Hoewel de wet van 30 mei i 847 maximaal $f$ i 90.000 , - toestond, was dit bedrag door de Minister van Binnenlandse Zaken verminderd ${ }^{154}$. Het ontvangen subsidie was echter ruim tweemaal zo groot als in I 846.

De Maatschappij van Weldadigheid was in 1847 fortuinlijker dan in de voorgaande jaren: zowel de rogge als de aardappelen brachten meer op. Een oogst van 20,4 mud rogge/ha in de gewone koloniën was zelfs nooit tevoren verkregen! Men had dan ook een overschot van bijna 2500 mud. Niettemin oogstte men in de omgeving van de koloniën in dit jaar \pm 30 mud rogge per ha, hetgeen de directeur in de Algemeene Oogststaat een normaal verschil noemde. De Maatschappij had te kampen met veel onkruid, vnl. dravik, waarvan het graan moeilijk was te zuiveren. Men zou echter zorgen voor zuiverder zaaizaad. Ook duurde de roggeoogst in de koloniën altijd langer dan daarbuiten; in 1847 resp. 3 en 2 weken. Dit verschil was te wijten aan de taxatie, die één week in beslag nam, maar door de aanhoudende droogte geen schade veroorzaakte ${ }^{155}$.

De aardappelziekte deed ook in 1847 weer van zich horen in alle koloniën. Maar de verbetering, vergeleken met de voorgaande jaren, deed de verdwijning van deze ziekte verwachten. Evenwel had men dit jaar ook last van de rotziekte, die andere aardappelen in de kuil zou aansteken, hetgeen volgens de directeur nog niet was bewezen ${ }^{156}$. Als het weer dit toeliet, zou het poten van de aardappelen in I 848 op de normale datum van 15 maart beginnen.

Ook in 1848 ontving de Maatschappij weer een regeringsbijdrage in verband met de gedeeltelijk mislukte aardappeloogst; het bedrag beliep $f 86.000$, -157.

In tegenstelling tot de verwachting teisterde de aardappelziekte de koloniën in 1848 in ongekende mate: de oogst was geringer dan ooit tevoren, terwijl bovendien ruim I $8 \%$ van de oogst in de gewone koloniën door ziekte onbruikbaar was. Deze zieke aardappelen kon men, gedeeltelijk in plaats van brood, opvoeren aan de ossen, oude guste koeien en ook aan melkkoeien. De totale schade in alle koloniën (incl. de gestichten) werd becijferd op minstens 60.000 mud à $f x, 50=f^{\prime} 90.000$, . Toch waren in I 848 vrijwel alle poters per I mei in de grond. Vroeg poten vond men de beste bescherming tegen de ziekte. Desondanks was de plaag, na de nachtvorst in mei, zo hevig, dat ook onder de vroege aardappels veel zieke en rotte voorkwamen. De ziekte was in het noorden van het land erger dan in het zuiden, in Noord-Europa was zij weinig 
aangetroffen. In dit vierde achtereenvolgende jaar van de aardappelziekte veronderstelde Van Konijnenburg, dat de hoofdoorzaak mogelijk in de luchtgesteldheid was gelegen ${ }^{158}$.

Begin I 849 verleende de regering wederom een subsidie, ditmaal van $f 80.000,-$. Dit was echter voor de Maatschappij niet meer dan een druppel op een gloeiende plaat: de financiële toestand verslechterde voortdurend 159 .

Het is wel typerend, dat de Permanente Commissie in deze benarde situatie, althans in haar officiële publikaties, een optimistische toon liet doorklinken, die getuigde van een grote mate van zelfingenomenheid. Zo bestond de beantwoording van de aanbevelingen van de Groninger hoogleraar Van Hall grotendeels uit een afwijzing van zijn voorstellen'160. Naar de mening van de Permanente Commissie waren de koloniën, wat de opbrengst van de rogge betrof, niet achter bij de gemiddelde oogst elders volgens opgaven in de Staten van Landbouw:

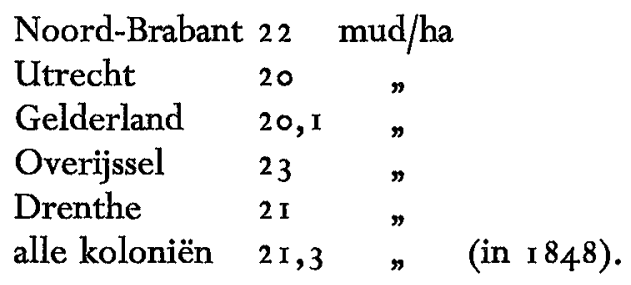

Dit zijn echter slechts cijfers van één jaar, waarin men in de gewone koloniën niet meer dan $16,9 \mathrm{mud} / \mathrm{ha}$ oogstte. Ook uit hiervoor aangehaalde opmerkingen van de directeur, geplaatst bij de voor intern gebruik bestemde oogststaten, blijkt toch wel duidelijk, dat Van Konijnenburg deze opvatting van zijn bestuur niet deelde.

Van Hall had tevens o.a. in overweging gegeven de granen meer te wieden, waar men over voldoende arbeidskrachten beschikte, hetgeen in de koloniën in het algemeen het geval was. Ook raadde hij de beproeving van de rijenteelt in dit verband aan. De Permanente Commissie antwoordde hierop door te verklaren, dat de rijenteelt bij de boekweit reeds was beproefd. Men erkende het grote nut van het wieden. Dit werk eiste echter veel zorg en toezicht in verband met de onkunde van de bevolking, die het verschil tussen graan en onkruid vaak niet kende.

Terzelfder tijd drong ook Van Konijnenburg bij de Permanente Commissie aan op invoering van de rijenteelt met schoffelen, zowel voor de boekweitteelt als voor de graanverbouw ${ }^{161}$. Inderdaad werd volgens het Algemeen Verslag over 1849 de boekweit op zandgrond in dit jaar 
voor het eerst op rijen gezaaid, hetgeen goed voldeed. Voortaan zou men dit gewas overal in de koloniën op rijen verbouwen.

Voor de rogge schreef de Maatschappij met ingang van i 849 een "dunner tarief van zaaijing" voor, dat van kracht was in alle koloniën: tot lo oktober 2,5 mud/ha, van 1o oktober tot ro november $2,75 \mathrm{mud} / \mathrm{ha}$ en vanaf 10 november $3 \mathrm{mud} / \mathrm{ha}^{\mathrm{I} 62}$.

De aardappelziekte (ook "rotziekte" genaamd) was in $185^{\circ}$ weer heviger dan in het voorafgaande jaar. Men had getracht de ziekte te voorkomen door vanaf half maart ongeveer een derde gedeelte vroege aardappelen te poten. Door de vorst kon men pas op I april beginnen. Een maand later waren evenwel toch alle aardappelen in de grond. De kou in mei veroorzaakte een geringe groei, zelfs in juni trad nog nachtrorst op. Alleen de vroege aardappelen bereikten hun volle wasdom, vóór de ziekte inviel; de late brachten wederom het minst op. Vroeg poten bleef dus raadzaam, liefst tussen I 5 maart en I 5 april. In de gewone koloniën zou men onvermijdelijk ook alle fabrieksarbeiders aan het poten moeten zetten ${ }^{163}$. Verder merkte Van Konijnenburg nog op: „De oorzaak dezer ziekte blijft, na het zesde jaar van derzelver ontstaan, nog even onbekend. - Geen der bijzondere waarnemingen, die algemeen van toepassing wordt bevonden. Alleen blijft het verbouw op nieuw ontgonnen grond het beste en de grofste aardappelsoorten het meeste van de ziekte bevrijd."

Ook in 1851 verbouwde men bijna een derde deel van de aardappelen in de gewone koloniën als vroege, n.l. 60,6 van de 207,7 ha. Rotte (of zieke) aardappelen kwamen het meest voor te Willemsoord in verband met de zware, leemachtige grond, het minst te Wateren. Het opbrengstverschil tussen vroege en late aardappels blijkt uit onderstaande cijfers (gemiddeld $15 \%$ ).

Tabel I 2 - AARDAPPELOPBRENGST IN 185 I

\begin{tabular}{|c|c|c|c|}
\hline \multirow{3}{*}{ Kolonie } & \multicolumn{2}{|c|}{ Opbrengst in mud/ha } & \multirow{3}{*}{$\begin{array}{l}\text { Percentage zieke } \\
\text { aardappelen in } \\
\text { de oogst }\end{array}$} \\
\hline & vroege & late & \\
\hline & \multicolumn{2}{|c|}{ aardappelen } & \\
\hline I & 181 & 150 & I 8 \\
\hline II I & 141 & II 5 & 10 \\
\hline III & I 80 & $15^{8}$ & 22 \\
\hline Gewone koloniën & 167 & $14 \mathrm{I}$ & (vroege) 12 ; (late) 20 \\
\hline
\end{tabular}

Bron: Staat van den Aardappel-oogst in $185 \mathrm{x}$. 
Zoals reeds lange tijd het geval was, gaf ook in I $85 \mathrm{I}$ kolonie II (Wilhelminaoord) een relatief lage opbrengst. Nogmaals beval Van Konijnenburg de teelt van vroege aardappelen aan; met name noemde hij de graafjes (Westlandse en Engelse), de negenwekers en de roodleden. De late Rademakers wilde hij voortaan minder verbouwen.

Bij de Staat van den Rogge-Oogst in $18{ }_{5}$ I volgens de tauxatie weidde de directeur uit over de geringe roggeoogst in de koloniën, die blijkbaar ook in $185^{\circ}$ en $185 \mathrm{I}$ kleiner was dan in de omgeving: „Intusschen is het vreemd, dat de landlieden van den omtrek niet zoo zeer klagen over misgewas; wel zeggen zij schudt de rogge minder, maar ze garfde beter dan verleden jaar en is men alzoo in het algemeen te vreden over den verkregen oogst, terwijl ook de prijs der rogge, tot hiertoe nog niet van eenige beduidenis is gerezen. En toch mag de opbrengst in de Koloniën maar een half gewas heten en is er schier van geen enkel stuk een goed verbouw verkregen. Waaraan zulks toeteschrijven of hoe die bedenking op te lossen is durf ik niet bepalen." Het dunner zaaien kon volgens Van Konijnenburg de oorzaak niet zijn. In 1852 noemde hij echter de onvoldoende bemesting en het vele onkruid als oorzaken voor de doorgaans geringe roggeopbrengst in de koloniën in vergelijking tot de buitenwereld ${ }^{64}$.

Hoewel op I juli I 852 de aardappelziekte weer was gesignaleerd, toen na een vochtige juni-maand een grote hitte (meer dan $90^{\circ} \mathrm{F}$ ) inviel, meende de directeur deze hitte als hoofdoorzaak van de geringe opbrengst te kunnen zien, omdat onder de late aardappelen slechts weinig zieke waren aangetroffen. De plaatselijke directies werden uitgenodigd steeds meer vroege aardappelen te poten, ook al moest men hiervoor grote eetaardappels gebruiken. De oogst was eerst half november geheel achter de rug, doordat de katoenwevers in dit jaar niet als oogsthulp waren ingeschakeld. Voor de eerste maal waren in Willemsoord enige vreemde arbeidskrachten aangetrokken voor de aardappeloogst (eveneens in 1853$)^{165}$.

In de eerste wijk van kolonie I verbouwde men in 1853 op $1 / 8$ ha troshaver, die $63 \mathrm{mud} / \mathrm{ha}$ opbracht tegen gewone haver $31,8 \mathrm{mud} / \mathrm{ha}$. Bovendien was hier een vierde gedeelte van het Voorbroek $(4,7 \mathrm{ha})$ gescheurd en in onbemeste toestand met haver beteeld, die $37,5 \mathrm{mud} / \mathrm{ha}$ opleverde. De geoogste haver was steeds grotendeels afkomstig van snijhaver, die als zodanig niet benodigd was ${ }^{166}$.

Het spreekt vanzelf, dat de ongunstige oogsten van I $85^{2}$ en I 853 en de over het algemeen hoge prijzen van de levensmiddelen de financiële positie van de Maatschappij zeer benard maakten, zodat men een lening van niet minder $\operatorname{dan} f 822.000$, - moest afsluiten ${ }^{167}$. 
In 1854 bestond de aardappelverbouw voor $2 / 3$ deel uit vroege. De pootgoed-en zaaizaadhoeveelheden per ha bedroegen in dit jaar :

aardappelen 22 mud,

rogge 2,83 mud (gewone koloniën), resp. 2,75 mud (Wateren),

haver 4 mud,

gerst $\quad 2,70 \operatorname{mud}^{168}$.

Tegenwoordig gebruikt men bij 40.000 planten/ha ongeveer i 5 mud kleine pootaardappelen, bij rijenteelt tot 2 mud rogge en zomergerst per ha en \pm 4 mud haver, breedwerpig gezaaid. De pootgoed- en zaaizaadhoeveelheden waren destijds in het algemeen dus groter dan thans.

De aardappeloogst in de gewone koloniën ging ook in I 855 weer gepaard met moeilijkheden in de arbeidsvoorziening, omdat de katoenweverij gaande moest blijven en bijna de helft van de valide bevolking aan zich bond. Er was vreemde oogsthulp nodig voor 30 van de 200 ha. Alle soorten aardappelen, ook de vroege, waren in dit jaar door de aardappelziekte aangetast. Deze openbaarde zich vooral in een algehele stilstand van de groei; rotte aardappelen kwamen steeds minder voor.

In het jaar I $85^{6}$ trad de aardappelziekte voor de twaalfde maal op. Bij alle soorten bleven de knollen klein, hoewel de rode of bonte het minst waren aangedaan. Overigens ondervond men weer de meeste schade op de zwaardere, lemige grond. Wederom was vreemde hulp nodig voor het op tijd rooien ${ }^{\mathrm{x} 69}$.

De zaaizaadhoeveelheden bedroegen in 1857 per ha (in mud):

$\begin{array}{lcl}\text { aardappelen } & \text { kolonie I } & 27 \\ & \text { kolonie II } & \text { I9 } \\ & \text { kolonie III } & 24 \\ \text { Wagge } & \text { Wateren } & 22 \\ \text { haver } & \text { gewone koloniën } & 3 \\ & \text { Wateren } & 5 \\ \text { boekweit } & \text { kolonie I en II } & 0,75 \\ & \text { kolonie III } & \text { I } \\ & \text { Wateren } & \text { I, 25 } 5^{\text {I70. }} .\end{array}$

De redenen van de uiteenlopende hoeveelheden pootgoed voor de aardappelteelt en zaaizaad van haver en boekweit zijn niet nader aangegeven.

De geringere opbrengst aan rogge in 1857 , vergeleken met 1856 , zou volgens de directeur zijn te wijten aan „vervuiling van den grond, nog meer welligt dan aan een onvoldoende bemesting”. Het onkruid had de 
overhand gekregen, doordat de aardappelplanten slechts gedeeltelijk uitgroeiden wegens de aardappelziekte. Ook de brem groeide minder welig dan voorheen. De roggeverbouw in de koloniën was "wederom gebleven verre beneden de opbrengst daarbuiten", die Van Konijnenburg naar alle waarschijnlijkheid op $20 \mathrm{mud} / \mathrm{ha}$ dacht te kunnen stellen, d.i. $60 \%$ meer dan in de gewone koloniën' ${ }^{7 x}$.

Over de laatste jaren vóór de afscheiding van de gestichten van de gewone koloniën zijn oogstramingen gepubliceerd voor Frederiksoord (= gewone koloniën), Wateren en de Drentse essen, die een globale vergelijking mogelijk maken ${ }^{172}$. De ramingen betreffende de Maatschappij van Weldadigheid zijn opgesteld door de directeur, die voor de Drentse essen door S. van Roijen te Vledder. Zij zijn verzameld door de vereniging "De Volksvlijt” (bijlage 7).

Uit deze gegevens is af te leiden, dat de aardappelteelt in de koloniën ten opzichte van de Drentse essen blijkbaar doorgaans bevredigende resultaten had, vooral in de gewone koloniën. De rogge leverde inderdaad, waarschijnlijk voortdurend, kleine opbrengsten op, in het bijzonder in de gewone koloniën. Ten aanzien van de minder belangrijke gewassen haver, boekweit en gerst zijn feitelijk geen algemene conclusies te trekken uit de beschikbare cijfers.

Het grote, voor de Maatschappij nadelige verschil was dus gelegen in de relatief geringe opbrengst van de rogge in de gewone koloniën, waarschijnlijk te wijten aan een onvoldoende bemesting en een welige onkruidgroei. Vanzelfsprekend heeft ook de sinds 1845 heersende aardappelziekte de uitkomsten van de landbouw in de koloniën zeer ongunstig beïnvloed.

De oorzaak van de aardappelziekte heeft Van Konijnenburg in I 846 vrij goed aangegeven door te zinspelen op de mogelijkheid van een in de grond aanwezige schadelijke stof, die door een hitteperiode tot verdere ontwikkeling kon komen. Bergsma, hoogleraar in de landhuishoudkunde te Utrecht, heeft reeds in 1845 de oorzaak nader aangeduid door een schimmelplant te noemen als de meest waarschijnlijke mogelijkheidi 73 . Thans is bekend, dat de gewone aardappelziekte wordt veroorzaakt door de wierzwam Phytophthora infestans, waarvan het mycelium in de grond overwintert ${ }^{174}$.

\section{HET GRASLAND EN DE VEESTAPEL}

In de vrije koloniën van de Maatschappij van Weldadigheid is het grasland in de periode 18 I 8 - I 859 slechts van ondergeschikte betekenis geweest. 
Het accent van de opeenvolgende landbouwstelsels lag steeds op de akkerbouw, hoewel in de vruchtwisselingssystemen een plaats was ingeruimd voor tijdelijk gras- of klaverland (kunstweiden) en andere voedergewassen. De veestapel was dan ook in de eerste plaats bedoeld om zelf te kunnen voorzien in de zuivelbehoefte van de bevolking en gedeeltelijk in de mestbehoefte van het bouwland.

Over het blijvend en tijdelijk grasland is hiervoor reeds het een en ander meegedeeld, terwijl de verbouwde voedergewassen eveneens elders aan de orde zijn gesteld 175 . Hier kan derhalve worden volstaan met de vermelding van enige aanvullende bijzonderheden betreffende de veehouderij, waarbij de oppervlakte grasland zal worden beschouwd in verband met de grootte van de veestapel, zowel in de gewone koloniën als bij het Instituut voor de Landbouw te Wateren.

Het oorspronkelijke plan van Van den Bosch was gericht op de vestiging van een eenzijdig produktiepatroon met uitsluitend akkerbouw zonder rundvee ${ }^{76}$.

In de praktijk heeft de akkerbouw zonder enig rundvee in de koloniën slechts korte tijd standgehouden. Reeds in i 820 voorzag het kolonisatieplan voor de gewone koloniën in twee koeien per gezin, waarvoor $1 \frac{1}{2} \mathrm{mg}$ voedergewassen moest worden verbouwd. De aan de kolonisten verstrekte koeien bleven eigendom van de Maatschappij; voor het gebruik van de melk moest men $f$ o, i o per koe per week betalen en een klein gedeelte van de opbrengst van de verkoop van de kalveren, die wel het eigendom van de kolonisten waren ${ }^{177}$.

In de jaren $1821 / 1822$ bestond de veestapel uit het trekvee, t.w. paarden en ossen, verscheidene kudden schapen en het melkvee. Voor het gebruik van het trekvee door de kolonisten ontving de Maatschappij vergoeding. Dit vee was ook haar eigendom.

Von Grouner noemde in zijn reisbeschrijving het aanvankelijke gebrek aan veevoeder, dat noodzaakte tot aankoop van hooi buiten de koloniën. De directie verkocht het hooi door aan de kolonisten, die hierdoor te veel schuld aan de Maatschappij kregen. Het gevolg was, dat elk gezin voortaan slechts één koe en tien schapen mocht houden. De schapen waren overdag op de heide en 's nachts opgestald om mest te leveren.

De koeien van de kolonisten waren niet van het grote Hollandse type, noch van de Friese soort, maar van een klein, onaanzienlijk ras. Van den Bosch was van mening, dat de kwantiteit en kwaliteit van het veevoer in de ontginningsperiode geen groot veeslag veroorloofden. Later zou men op groter en beter vee kunnen overgaan.

Met uitzondering van het slechte aangekochte hooi en de af en toe ge- 
hooide snijrogge rekende Von Grouner het veevoer in de koloniën toen reeds tot de voedselrijke soorten: klaver en raaigras, fioringras, groene rogge, spurrie, boekweit en aardappelen.

De schapen hadden lange poten en waren vrij groot in tegenstelling tot de heideschapen. De wol was lang en donzig en werd in de koloniën verwerkt tot kleren, sokken etc. voor de kolonisten.

$\mathrm{Zij}$ hielden door henzelf gekochte varkens; verscheidene kolonisten hadden in 182 I zelf een paard en kar gekocht om loonwerk te verrichten. Anderen hadden de Maatschappij het huurvee teruggegeven en eigen vee gekocht.

Het was niet te ontkennen, zo besloot Von Grouner dit gedeelte van zijn reisverhaal, dat welstand en vlijt toenamen en aanleiding gaven tot goede hoop ${ }^{178}$.

Jan Kops rekende de schapen van de Maatschappij in I 823 , in tegenstelling tot Von Grouner, tot de kleine Drentse schapen met grove wol. Hij beval Friese en Texelse schapen aan; deze zouden betere wol opleveren. Ook drong Kops aan op een nieuwe proef met trekkoeien voor matige arbeid. De aanvankelijk gebruikte werkossen waren wegens hun trage gang en betrekkelijk geringe werkkracht vervangen door paarden.

Generaal Van den Bosch trachtte de kolonisten in de eerste jaren aan te sporen tot gemeenschappelijke boterbereiding. Deze gedachte had echter geen bijval ondervonden. Jan Kops gaf ook de voorkeur aan gezamenlijke boterbereiding, zoals in Zwitserland met voordeel gebeurde ${ }^{179}$.

Vanaf medio 1827 heeft de Maatschappij in haar tijdschrift De Vriend des Vaderlands maandelijks een opgave verstrekt van de in elke kolonie aanwezige hoeveelheid vee. Met behulp van deze gegevens is een jaaroverzicht samengesteld (bijlage 8). Hierin is uitsluitend het vee opgenomen, dat eigendom was van de Maatschappij van Weldadigheid. Sommige kolonisten hadden enig kleinvee in eigendom: b.v. in 1832 in totaal 87 kalveren en jongvee en 200 schapen en lammeren.

Uit de gegevens van bijlage 8 blijkt duidelijk, dat het beleid van de directeur Van Konijnenburg resulteerde in een toeneming van het aantal koeien in de gewone koloniën en te Wateren van resp. 451 en 18 eind 1827 tot 656 en 54 in 1835 . In verband met de door Van den Bosch in de volgende jaren doorgevoerde reorganisatie van de landbouw trad vervolgens in de omvang van de rundveestapel een scherpe daling in tot resp. 406 en 33 in 1838 . Het aantal koeien in de gewone koloniën was toen zelfs geringer dan in 1827 . In de 20 jaren na 1838 valt een geleidelijke toeneming van beperkte omvang te constateren tot resp. 476 en 49 koeien in $\mathrm{I} 858$. Uit het verloop van de jongveestapel te Wateren blijkt verder, hoe 
men hier in de jaren 1830 - 835 de fokkerij sterk uitbreidde en deze vervolgens weer ging inkrimpen.

De schapenhouderij was in de gewone koloniën in I 827 nog van veel betekenis (ruim I $_{4} 00$ schapen). In ${ }_{1} 8_{3}$ I-I $8_{3} 6$ hield de Maatschappij hier in het geheel geen schapen aan; vanaf 1837 bevond zich in kolonie II weer een kudde van \pm 300 stuks. De schaapskudde te Wateren is na 1830 vergroot tot ruim 1000 in 1837 , daarna geleidelijk gehalveerd (in I 843) en in de volgende jaren weer uitgebreid tot boven het duizendtal, waarbij de grootste omvang werd bereikt in I 854 met ruim 1300 dieren.

Zoals hiervoor reeds is vermeld, is het aanvankelijke doel van twee koeien per kolonistengezin nooit verwezenlijkt. In I 827 hadden 32 I gezinnen 455 koeien ter beschikking ${ }^{180}$, dus per gezin gemiddeld $\mathrm{r}, 4$. In onderstaande tabel is de melkveedichtheid voor enkele jaren weergegeven betrokken op het aantal gezinnen in de gewone koloniën, resp. de oppervlakte grasland (incl. kunstweide) in deze koloniën en te Wateren.

Tabel I 3 - MELKVEEBEZTTING I 827-I 854 (I857)

\begin{tabular}{|c|c|c|c|c|c|}
\hline \multirow{3}{*}{ Jaar } & \multicolumn{5}{|c|}{ Aantal melkkoeien in } \\
\hline & \multicolumn{3}{|c|}{ de gewone koloniën } & \multicolumn{2}{|c|}{ Wateren } \\
\hline & totaal & per gezin & $\begin{array}{l}\text { per roo ha } \\
\text { grasland }\end{array}$ & totaal & $\begin{array}{l}\text { per Ioo ha } \\
\text { grasland }\end{array}$ \\
\hline 1827 & 455 & 1,4 & 70 & 18 & 69 \\
\hline 1834 & 604 & $\mathrm{I}, 3$ & 144 & 49 & $4^{8}$ \\
\hline 1840 (g.k.), $184^{2}(\mathrm{~W})$. & 439 & 0,9 & $35 \mathrm{I}$ & 32 & 56 \\
\hline 1854 (g.k.), I 857 (W.) & 474 & 0,9 & 160 & 46 & 85 \\
\hline
\end{tabular}

Incl. kunstweide.

Bronnen: hiervóór hfdst. IV, I (oppervlakte grasland), bijlage 8 (veestapel),

Algemeene Verslagen (bevolkingscijfers).

Uit bovenstaande verhoudingscijfers blijkt, dat het aantal melkkoeien per gezin door de hervormingen in de jaren $1836 \mathrm{t} / \mathrm{m} \mathrm{I} 839$ terugviel tot beneden het gemiddelde van één koe. Daarentegen was de melkveebezetting per $\mathrm{i} 00$ ha grasland door de drastische inkrimping van de groenvoederoppervlakte omstreeks $184^{\circ}$ in de gewone koloniën zeer hoog. Dit noopte tot de hiervoor reeds genoemde omvangrijke hooiaankopen. Te Wateren waren de fluctuaties veel minder sterk, terwijl de melkveedichtheid aanmerkelijk geringer was dan in de gewone koloniën. Men 
kan concluderen, dat de veestapel van het Instituut beter was afgestemd op de eigen ruwvoederwinning.

De varkenshouderij was in de gewone koloniën een privé aangelegenheid van de kolonisten. Voor de huisslacht hielden zij in september I 829 b.v. I 53 mestvarkens op 329 gezinnen ${ }^{18 x}$.

De schaapskudden werden in 1828 en 1829 geteisterd door veeziekten, die een sterke vermindering van het aantal schapen (bijlage 8) en van de hoeveelheid mest veroorzaakten ${ }^{\mathrm{I}} \mathbf{2}$.

Omstreeks $183^{\circ}$ ging Van Konijnenburg te Wateren de rundveefokkerij uitbreiden, opdat in alle koloniën de veestapel door eigen aanfok zou kunnen worden vergroot. In oktober I 83 I waren op de hoeven te Groot Wateren reeds \pm 20 stuks jongvee. Dit aantal wilde men vóór de winter vermeerderen tot 40 à 50 , in $183^{2}$ tot zelfs $15^{183}$. Zo ver is het echter nooit gekomen (bijlage 8).

Over de kippenhouderij leest men slechts weinig in de archiefstukken van de Maatschappij. Deze bedrijfstak was feitelijk sedert 1830 in de gewone koloniën niet toegestaan. Het Algemeen Verslag van dit jaar vermeldt, dat bij inspectie van de hoeven was gebleken, „dat onderscheidene kolonisten hoenders hielden, die bij velen niet dan ten koste der Maatschappij worden gevoed, terwijl anderen honden er op nahielden, hetgeen nutteloos en kostbaar is. Alle deze misbruiken moesten ophouden." Het houden van kippen en honden werd verboden; op overtredingen werden straffen gesteld.

In 1832 pleitte Van Konijnenburg voor de verbouw van klaverhooi in de koloniën. "Het aanmaken, in stand houden en verbeteren van groenland is, mijns bedunkens, de sleutel der geheimenis in de landbouw, inzonderheid in dien der Koloniën"184. Dit pleidooi hing samen met de mijns inziens juiste mening van de directeur, dat men de veestapel aanmerkelijk moest vergroten, wilde men tot een gezonde landbouw komen.

Over de opbrengst aan zuivel over de periode 1 november I 83 I tot I november I 832 verschafte Van Konijnenburg de volgende gegevens. In de gewone koloniën raamde hij de boteropbrengst van 516 koeien op $25.800 \mathrm{Ned}$. pond $(=\mathrm{kg}$ ), d.i. gemiddeld $50 \mathrm{~kg}$ per koe. Deze boter was eigendom van de kolonisten voor eigen gebruik. Te Wateren leverden 24 koeien een (gemeten) hoeveelheid van 52 I $\mathrm{kg}$ op, d.i. $22 \mathrm{~kg}$ per koe. De gemiddelde produktie stelde de directeur voor alle koloniën tezamen op ruim $28 \mathrm{~kg}$ boter per koe ${ }^{185}$. Deze opbrengsthoeveelheden bedragen slechts $25-50 \%$ van de in die tijd elders verkregen opbrengst van goed gevoerde en verzorgde koeien, aldus deelde Van Konijnenburg mede. 
Ter illustratie diene, dat Wardenburg in 1829 de gemiddelde opbrengst van een 's zomers en 's winters goed gevoerde koe op $100 \mathrm{~kg}$ boter stelde. De jaarlijkse melkproduktie berekende hij op grond van enkele literatuurbronnen op globaal 2400-2900 liter. Hij vermeldde verder, dat Hora Siccama (Groningen) voor I kg boter $32 \mathrm{l}$ melk aanhield, Aelbroeck (Vlaanderen) echter niet meer dan 261 in verband met een hoger vetgehalte ${ }^{86}$. De tegenwoordige gift aan botervet per koe kan men wel $50 \%$ hoger stellen, dus op $\pm 150 \mathrm{~kg}$ per jaar.

Het Algemeen Verslag over I 832 werpt enig licht op de moeilijke positie van de ruwvoederwinning in de koloniën. Met uitzondering van een klein aantal hoeven kon men in de gewone koloniën wegens het mestgebrek geen hooi winnen. Onder Eesveen (gemeente Steenwijkerwold) had de Maatschappij $\pm 3,5$ ha hooiland gehooid, alsmede van een stuk land in de $\mathrm{Ma}$ achter Nijensleek enig boshooi. Overigens waren hier in de zomer, evenals op een ander perceel, i 5 guste koeien vetgeweid.

De kalveren, in de gewone koloniën eigendom van de kolonisten, werden voor het grootste deel kort na de geboorte geslacht of verkocht. In 1832 betrof dit 340 stuks. Om de veestapel uit te breiden ging de Maatschappij ertoe over het aanhouden van vaarskalveren door de kolonisten aan te moedigen. Als deze drachtig waren (meestal vóór de derde winter) nam de directie ze over tegen marktprijs, verminderd met de waarde van het geleverde hooi. In december 1832 hielden de kolonisten echter slechts 46 kalveren aan. Tevens hadden zij „ettelijke Vriesche schapen" voor eigen rekening ${ }^{187}$.

De veefokkerij te Wateren, aangevangen in 1832 , leverde in het volgende jaar reeds vee af aan de gewone koloniën, t.w. to koeien en 2 I drachtige vaarzen. „Volgens het plan moest er zoo veel vee zijn, als in het geven van mest gelijk stond met 3919 koeijen en er was, op I Januarij I 834, slechts zoo veel als gelijk staat met I 754 koeijen, zijnde bijna 45 honderdste" 188 .

Als gevolg van de inzichten van de directeur nam de veestapel toe: in 1834 met 52 koeien of ruim $8 \%$ in de gewone koloniën. "Aan de tweede koe voor iederen kolonist ontbreken er nu nog 140 ", aldus Van Konijnenburg in de Algemeene Oogststaat over I 834. De veefokkerij te Wateren leverde in dit jaar wederom $2 \mathrm{I}$ vaarzen en 3 pinken an de gewone koloniën af ${ }^{\mathrm{r}} 89$.

De oude guste koeien uit de gewone koloniën gingen vanaf I 834 naar de gestichten om te worden vetgemest voor gebruik aldaar ${ }^{190}$. De veesterfte veroorzaakte een „zeer gering verlies”, hetgeen getuigde van een „behoorlijke behandeling van het vee". Niettemin stierven in alle 
koloniën gezamenlijk in 1833 van de 2300 schapen rog stuks of $5 \%$, van de 1030 koeien 19 stuks of $2 \%$. De gemiddelde boteropbrengst per koe bedroeg in dit jaar voor alle koloniën $5^{2} \mathrm{~kg}$ boter, d.i. bijna het dubbele van 1832 . Te Wateren was de produktie echter verminderd van 22 tot I $6 \mathrm{~kg}$ per $\mathrm{koe}^{\mathrm{I} 9 \mathrm{I}}$.

Deze daling stond waarschijnlijk in verband met de veefokkerij en de moeilijke ruwvoedervoorziening. Zo bedroeg de produktie te Wateren in 1834 :

r. van 4,8 ha klaverland en ander nieuw groenland à $2316 \mathrm{~kg}$ per snede per ha:

2. van 74,9 ha oud natuurlijk groenland à $\mathrm{r}, 000 \mathrm{~kg}$ : : II $.000 \mathrm{~kg}$. $76.500 \mathrm{~kg}$.

Totale eigen produktie: $87.500 \mathrm{~kg}$.

Men moest voor Wateren $100.000 \mathrm{~kg}$ hooi aankopen. Verder werden in de verbeterde Oude Willem ( 50 ha, begrepen onder 2) na de eerste snede 90 stuks jongvee geweid. Hierbij zij opgemerkt, dat het oude grasland niet werd bemest.

In de gewone koloniën was de verhouding tussen eigen produktie en hooiaankoop aanzienlijk ongunstiger. Met uitzondering van kolonie I leverden de hoeven door de geringe bemesting geen hooi op. Eigen produktie in 1834 :

r. van 1 4,6 ha klaverland (4r hoeven) in kolonie I, bij het Broek gelegen,

$1265 \mathrm{~kg} / \mathrm{ha}$ :

$18.45^{\circ} \mathrm{kg}$.

2. van 3,5 ha oud grasland, het z.g. Haverland onder Eesveen, $1285 \mathrm{~kg} / \mathrm{ha}: \quad 4.500 \mathrm{~kg}$.

Totale eigen produktie: $\mathbf{2 2 . 9 5} \mathrm{kg}$. Aangekocht niet minder dan $740.000 \mathrm{~kg}$.

Bovendien kon men het Westerbroek en de Ma onder Nijensleek slechts als weide gebruiken voor 22 oude guste koeien ${ }^{192}$. Deze cijfers geven wel een treffend beeld van het zeer grote gebrek aan goed grasland in de gewone koloniën!

Van Konijnenburg adviseerde, behalve diep losspitten van de vele stukken vaste ontginningszandgrond, de klaver en het raaigras dikker te zaaien in de rogge, nl. $15 \mathrm{~kg}$ klaver- en $5 \mathrm{~kg}$ raaigraszaad per ha. Deze hoeveelheden zaaide men destijds ook overal elders ${ }^{193}$. Tegenwoordig houdt men ongeveer dergelijke hoeveelheden aan of zaait men minder uit.

Ook in 1835 nam de veestapel toe, $\mathrm{nl}$. van 1907 (omgerekende) koeien per I januari tot 2033 per 31 december. Deze aantallen hadden betrekking op alle veesoorten in alle koloniën. Van Konijnenburg voegde 
hieraan de opmerking toe: „En de sterkte, naar het aan de Permanente Commissie aangeboden plan, behoorde te zijn gelijk aan 3.919 stuks koeyen, waar ze dus nog met 1886 stuks beneden is" ${ }^{194}$. Blijkbaar had de directeur derhalve een plan tot vergroting van de veestapel aan het bestuur voorgelegd. Uit de verdere gang van zaken is af te leiden, dat de Permanente Commissie dit plan van de directeur niet ten volle onderschreef.

Ook was er een meningsverschil tussen directie en bestuur over de door eerstgenoemde geraamde opbrengst van de melkkoeien der kolonisten. Van Konijnenburg zou te hoog schatten, hetgeen hij ontkende. Volgens een potloodaantekening bij de Algemeene Oogststaat van I 835 was de mening van (waarschijnlijk) één der bestuursleden : „Is wel degelijk zoo. Ik begrijp niet, hoe men ter goeder trouw kan stellen, dat de koeijen in de gewone Koloniën zoo veel zuivel zouden geven." Ook meende de directeur, dat men te Wateren meer schapen kon houden. Inderdaad is dit aantal in 18,6 bijna verdubbeld.

Geheel in strijd met de opvattingen van Van Konijnenburg kwam generaal Van den Bosch in 1836 met zijn reorganisatieplan, dat juist voorzag in een drastische vermindering van het aantal stuks vee met gelijktijdige uitbreiding van de bremcultuur ${ }^{195}$. Voortaan kregen in verband met het veevoedergebrek alleen nog de z.g. valide gezinnen (2/3 van het totaal), die in de landbouw konden werken, de beschikking over één koe. Aan de invalide kolonisten werden de koeien, die alle eigendom van de Maatschappij waren, ontnomen. Per sectie van I 2 gezinnen achtte Van den Bosch één os nodig voor de veldarbeid. Deze trekdieren werden gestald bij en verzorgd door hiervoor aangewezen kolonisten, $\operatorname{die} f \mathrm{I}$, 一 per dag extra ontvingen, waarvan de helft in contanten. In 1838 zou men beginnen met de intrekking van de koeien van de invalide gezinnen, tenzij deze voor eigen rekening hooi wilden kopen.

Nog in I 835 moest Van Konijnenburg een aantal „oude en sukkelende beesten" uit de gewone koloniën overbrengen naar het gesticht te Ommerschans voor de vetmesterij, hetgeen aldaar een grotere sterfte veroorzaakte. Hij was het ook met deze maatregel niet eens : „Ik herhaal, het was eene verkeerde berekening zulke oude koeijen, die, om bekende redenen, veel te lang als melkkoeijen gehouden waren, te willen vetmesten of weiden, terwijl dezelve beter tot alle prijzen waren verkocht geworden"196.

De hooioogst was in 1836 zeer matig. Weliswaar leverde het z.g. Haverland, dit jaar 5,5 ha groot, $12.500 \mathrm{~kg}$ hooi op, d.i. bijna het dubbele per ha van I 834 , maar men verkreeg slechts van enkele hoeven 
in kolonie $\mathrm{I} \pm 1000 \mathrm{~kg}$ klaverhooi. Verder was geen hooi gewonnen. Percelen oud groenland in het Broek en de Ma waren voor de vetweiderij gebruikt.

Te Wateren was de hooioogst in 1836 minder dan de helft van die in I 834:

I. van 9 ha klaverland bij het Instituut iste snede

$11.000 \mathrm{~kg}$.

(de grond was hier onvoldoende ontzuurd)

2. van 24 ha oud hooiland (de Ma's te Groot Wateren)

3. van 33 ha nieuw groenland (de Oude Willem)

$20.000 \mathrm{~kg}$.

$7.000 \mathrm{~kg}$.

Totale eigen produktie: $38.000 \mathrm{~kg}$.

In dit jaar was ook overal buiten de koloniën weinig hooi door het ongunstige weer; de prijzen per $500 \mathrm{~kg}$ lagen $f_{\mathrm{r}}$, - à $f_{2}$, - hoger dan normaal 97.

De eerdergenoemde aanzienlijke vermindering van de rundveestapel had plaats in 1837 door verkoop, deels van jongvee. De inkrimping bedroeg in dit jaar $\pm 20 \%$ (melkkoeien). Het is opvallend, dat de directeur met geen woord repte van de "voordelen" van de reorganisatie!198 Wel vermeldde hij bij de Algemeene Oogst-Staat van 1 837, dat het vee in alle koloniën gezamenlijk door de vermindering $\pm f 8000$,minder opleverde. Ondanks of juist door de grotere mestaankoop in 1837 was de totale netto opbrengst van de landbouw in de gewone koloniën

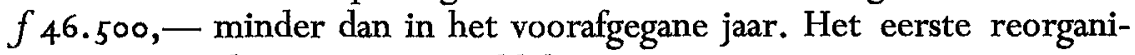
satie jaar was dus geen succes gebleken.

De totale omvang van de veeverkopingen voor alle koloniën blijkt uit onderstaande gegevens ${ }^{199}$ :

\begin{tabular}{lrr} 
& \multicolumn{2}{c}{ Verkocht in } \\
& 1836 & 1837 \\
paarden & 7 & 19 \\
koeien & 74 & 240 \\
jongvee & 144 & 621 \\
\hline totaal & 225 & 880
\end{tabular}

Vooral de jongveestapel, aangefokt overeenkomstig het beleid van de directeur, moest het ontgelden!

In het Algemeen Verslag over 1837 is sprake van een proef ter veredeling van de Drentse schapen. Door bemiddeling van de Administrateur voor de Nationale Nijverheid ontving de Maatschappij van de heer Numan te Utrecht, directeur van de Rijksveeartsenijschool, twee z.g. 
Zuiderduinrammen en één ram als kruising van een Merinoschaap met een Zuiderduinram ${ }^{200}$. Over de resultaten van de veredelingsproef is later niets vermeld, zodat deze waarschijnlijk niet gunstig zijn geweest.

De drastische verkleining van de veestapel duurde in 1838 nog voort en bedroeg in de gewone koloniën wederom ruim $20 \%$ tot 406 melkkoeien. Hiervoor was I $84 \mathrm{mg}$ groenland (blijvend grasland en klaverkunstweide) beschikbaar (= I $5^{8} \mathrm{ha}$ ). De melkveebezetting was dus nog steeds hoog, doordat ook de oppervlakte groenland was verminderd. Bovendien was de weide "uiterst schraal en onbemest gelaten, zoodat dezelve nauwelijks toereikend kon worden geoordeeld voor eene koe op het $\mathrm{mg}{ }^{201}$. Omdat het niet gehooide groenland I $_{3} 8 \mathrm{mg}$ besloeg, is het onbegrijpelijk, dat voor de gewone koloniën geen hooi behoefde te worden aangekocht (te Wateren nog slechts voor $f_{400,-)}$ ).

Ten aanzien van de veevoeding is in de Algemeene Oogststaat van $18{ }_{3} 8$ te lezen, dat men in de gewone koloniën de z.g. halve stalvoedering toepaste, d.w.z. dat de koeien 's zomers alleen overdag werden geweid (getuurd) en 's nachts op stal stonden. De stalvoedering werd destijds sterk gepropageerd in verband met de mestwinning. Te Wateren bleef het rundvee des zomers ook 's nachts in de weide.

De schapenhouderij door de kolonisten zelf is in $r 838$ verboden, ook in verband met beschadiging van boomaanplant. De beperking van het aantal koeien en de andere hervormingen, waarvan de invoering "eene zekere ontevredenheid scheen te hebben verwekt", deed de inspectiecommissie in dit jaar spreken van „den staat van spanning, waarin zich de gemoederen in de gewone Koloniën bevinden". Meer kolonisten hadden ontslag genomen dan voorheen. De commissie adviseerde dan ook niet verder te gaan door nog meer beperkingen in te voeren ${ }^{202}$.

Als trekdieren waren in 1839 uitsluitend ossen in gebruik. Als voordelen noemde men: $x$. na hun diensttijd vormden zij geschikt slachtvee; 2. de voerkosten bedroegen per os per week slechts $\pm f \mathrm{r}, 4^{\circ}$ (brood), van een paard $\pm f 2,5 \circ$ (haver). De inspectiecommissie merkte echter op dat de ossen in veenachtige grond te veel wegzakten en overal te langzaam werkten. Bovendien kon men met paarden beter ploegwerk verrichten ${ }^{203}$.

In het Algemeen Verslag over I 839 raamde men de zuivelopbrengst per koe in de gewone koloniën op $60 \mathrm{~kg}$ boter (in I $832: 50 \mathrm{~kg}$ per koe). Te Wateren bedroeg de gemeten produktie in $1837: 28,64 \mathrm{~kg}$, in 1838 : $33,62 \mathrm{~kg}$, in $1839: 40,74 \mathrm{~kg}$ boter per koe (in I $832: 22 \mathrm{~kg}$ ). Hier was de produktie per koe in 7 jaar dus bijna verdubbeld in verband met het afgenomen melkverbruik voor de fokkerij. 
Niettemin was de opbrengst te Wateren nog relatief gering door „bekende oorzaken, die men zoo goed mogelijk tracht weg te nemen”. Neemt men echter in aanmerking, dat Alstorphius Grevelink ter zelfder tijd opgaf, dat de boteropbrengst per koe naar de plaatsen in Drenthe varieerde van 30-50 Ned. p.204, dan kan men de opbrengst te Wateren in 1839 niet anders dan normaal noemen. De geschatte produktie in de gewone koloniën was daarentegen zeer waarschijnlijk aan de hoge kant.

Een „noodlottige ziekte” onder het rundvee en de duurte van het vee bemoeilijkten in I 839 de vervanging van de oude of gestorven koeien van de kolonisten. Als schadevergoeding betaalde de Maatschappij aan een kolonist voor elke koe, die hij miste, $f \circ, 5^{\circ}$ per week uit. De veeziekte was een besmettelijke long- en mondziekte. In de gewone koloniën mocht men evenwel weer per gezin twee koeien hebben, indien de kolonist in staat was van de gezinsverdiensten wekelijks voldoende geld bij de directie tegoed te laten staan voor de aankoop van hooi voor de tweede $k^{205}$. Inderdaad nam de veestapel in de jaren na 1838 weer langzaam toe (bijlage 8).

Ook in 1839 waren de hooiaankopen zeer omvangrijk. Hoewel Van Konijnenburg de hooioogst in de gewone koloniën als „zeer voldoende” beoordeelde, moest in dit jaar volgens raming niet minder dan 320.000 $\mathrm{kg}$ worden aangekocht. Voor Wateren nam men $54.000 \mathrm{~kg}$ over van het I ste gesticht te Veenhuizen ${ }^{206}$.

De klaver- en grasverbouw was in I 841 "allerongunstigst”. De directeur merkte op: "De uitbreiding van de brem-cultuur maakt ook de oppervlakte groenland geringer dan vroeger" 207 .

De veevoederpositie was in de gewone koloniën ook in 1842 zeer benard. De oppervlakte groenland bestond in dit jaar uit:

hooiland $\quad 63 \mathrm{mg}$ (oud groenland, gerst, klaver en uitgezaaid gras), weiland $108 \mathrm{mg}$,

ander groenland I $20 \mathrm{mg}$ (snijvoer voor de zomer).

$$
\text { Totaal } 29 \mathrm{rmg}=250 \mathrm{ha} \text {. }
$$

De veestapel bestond (excl. de vrijboeren) uit 377 koeien en 36 ossen en stieren, die men gelijk stelde met 72 koeien. Gezamenlijk dus 449 koeien, d.i. I 80 koeien per 1 00 ha. Het veevoedertekort was zo groot, dat 12.000 mud krielaardappelen werd vervoerd, terwijl bovendien nog $500.000 \mathrm{~kg}$ hooi werd aangekocht, ruim $50 \%$ meer dan in 1839 .

Te Wateren werd hooi gewonnen van I $2 \mathrm{mg}$ bemest groenland bij het 
Instituut, $6 \mathrm{mg}$ te Groot Wateren, $24 \mathrm{mg}$ oud grasland (madeland) en $24 \mathrm{mg}$ te Oude Willem. Bovendien verkreeg men enig spurriehooi van oud boekweitland en zelfs wat hooi uit heidevennen, die in normale jaren onder water stonden, maar in het droge jaar $\mathrm{r} 84^{2}$ geen water bevatten. De kwaliteit van dit hooi zal wel niet bijzonder goed geweest zijn! In de zomer ging men zeer zuinig met het veevoer om door het vee b.v. gedeeltelijk te voeren „met aardappellof en ander onkruid en door hetzelve in de heide te weiden te laten". Deze bijzonderheden werpen wel een schril licht op de bedrijfsvoering in de koloniën! Ondanks alle zuinigheid moest men voor Wateren toch nog $30.000 \mathrm{~kg}$ hooi aankopen 208 .

Het volgende jaar was voor de gewone koloniën een nog weer grotere hooiaankoop nodig, n.1. $522.000 \mathrm{~kg}$, om 's winters met I mud aardappelen per koe per week rond te kunnen komen. Te Wateren was de hooioogst echter met aardappelen en stro voldoende voor de behoefte. Door de vermindering van het aantal schapen liep de oppervlakte bemest groenland terug; men moest meer moeite doen om genoeg hooi te krijgen, dit „overal op te zoeken en zorgvuldig te verzamelen"209.

De zuivelopbrengst in de gewone koloniën is ook in 1843 weer geschat op $60 \mathrm{~kg}$ boter per koe. Volgens de directeur was er "geen twijfel aan, of de kolonisten hebben dat jaar de geraamde hoeveelheid zuivel verkregen, te meer daar de goede zorg van den kolonist voor de beminde koe weinig te wenschen overlaat". In Wateren was van 19 melkkoeien gemiddeld $5^{\circ}, 5 \mathrm{~kg}$ boter verkregen, dus $10 \mathrm{~kg}$ meer dan in 1839 . Van Konijnenburg vond de opbrengst in Wateren evenwel relatief klein door het voedergebrek: 's zomers een schrale weide, 's winters "een weinig hooi, benevens gekookte aardappelen en ook afgemaaide heide ..." Het vee te Wateren was kleiner van stuk dan in de andere koloniën ${ }^{210}$.

Ten aanzien van de behandeling van het vee door de kolonisten sprak de directeur zichzelf tegen door in verband met het relatief lage sterftecijfer voor het rundvee in de koloniën te verklaren, dat ${ }_{n}$ zeer veel beesten aan min kundige kolonisten moeten worden toevertrouwd, die, in alle gevallen, geen eigenaars zijn, bij wie men dus kwalijk de nodige zorg kan veronderstellen"2 II.

In I 844 moest voor het seizoen $1844 / 45$ alleen in de gewone koloniën voor $f 3774,-$ - hooi worden gekocht, voor alle koloniën gezamenlijk voor $f 6500$, - . "Of men echter, door voor $f 6500$, - meer mest aan te koopen, in plaats van zulk eene som in hooi te besteden, niet ruim het ontbrekende hooi zelf zou hebben kunnen winnen en tevens beter land, voor volgende gewassen, in een volgend jaar overlaten, is eene belang- 
rijke vraag, der overweging wel waardig”, aldus Van Konijnenburg212.

Dit lijkt inderdaad een reële uitspraak te zijn, hoewel de suggestie van de directeur door het bestuur van de Maatschappij blijkbaar naast zich neer is gelegd. In I 845 zei eerstgenoemde, dat de hooioogst sinds I 840, dus na de reorganisatie in de landbouw, steeds terug was gelopen, en de hooiaankopen tegelijkertijd groter werden. Voor $1845 / 46$ besteedde men aan hooi voor de gewone koloniën $f 9.275,50$, d.i. $2 \frac{1}{2} \times$ het bedrag van I $844 / 45$, voor Wateren $f 657,5^{\circ 213}$.

De zuivelopbrengst te Wateren nam niettemin toe tot gemiddeld $52,97 \mathrm{~kg}$ boter per koe in 1845 . De vooruitgang hield stand en zou dit nog lang kunnen, ,wanneer de stalvoedering maar toeneemt, waarop men zich dus moet blijven toeleggen"2I4. Evenwel was het vee te Wateren volgens de Algemeene Oogststaat 's zomers ook 's nachts buiten, zodat van zomerstalvoedering hier nog geen sprake was.

In het overigens uitvoerige rapport van Staring over de landbouwkundige situatie in 1846 zoekt men tevergeefs naar opmerkingen over de behandeling van het grasland. Wel gaf ook hij de voorkeur aan de aankoop van meer mest boven uitbreiding van de veevoeraankopen, zoals de directeur eerder had voorgesteld. Over de toestand van het vee rapporteerde Staring als volgt: „Behalve op de magerheid der meeste paarden, ten gevolge van overspannen arbeid, valt er niets aan te merken op den toestand van het Vee; een duidelijk bewijs, dat de behandeling daarvan niets te wenschen overlaat. Het rundvee is het voor dezen bodem juist passende Drenthsche, hetwelk tevens de meest geschikte trekossen oplevert." Op de hoeven trof Staring hier en daar koeien met ongeneeslijke gebreken aan, die voor vervanging in aanmerking kwamen. De lagere beambten hadden blijkbaar geen volmacht om deze dieren direct af te voeren. Staring gaf de inrichting van centrale ziekenstallen voor het zieke vee in overweging.

Over de varkens zei Staring: „De varkens zijn allen van het inlandsche ras. Te wenschen ware het, dat men ook in de Koloniën overging tot het veel voordeeliger Engelsche ras, hetwelk binnen weinig jaren in Overijssel zoo zeer verspreid is geworden, dat het thans weinig moeite zal kosten om zich hiervan te voorzien."

Ten slotte gaf Staring in dit gedeelte van zijn rapport een pleidooi voor de oprichting van een centrale rundveefokkerij te Wateren, zoals Van Konijnenburg die vroeger reeds had ingericht in de jaren omstreeks I 830-1 835. Hij had deze op gezag van Van den Bosch moeten opheffen. Staring merkte verder op, dat het jongvee in het eerste jaar stalvoedering 
met droog voer zou moeten ontvangen, terwijl men voor het twee- en driejarige vee over voldoende weiland diende te beschikken ${ }^{215}$.

Directeur Van Konijnenburg was kennelijk ook nog steeds een voorstander van een veefokkerij. In 1847 vermeldde hij namelijk, dat de veestapel dit jaar in alle koloniën was vergroot, terwijl deze in vorige jaren nauwelijks op peil was gebleven. In de loop van 1848 zou het aantal stuks rundvee „aanzienlijk” worden uitgebreid. Bij deze tekst van de directeur treft men een potloodaantekening aan: „Waardoor?”, waarschijnlijk afkomstig van een bestuurslid ${ }^{216}$. Het is wel zeker, dat Van Konijnenburg ook deze maal door het bestuur in de uitvoering van zijn voornemens is gedwarsboomd; men leest er verder niets meer over, terwijl de veestapel in 1848 en volgende jaren praktisch niet is vergroot (bijlage 8).

Het jaar 1847 was bijzonder droog. In de koloniën kon alleen de eerste snede worden gehooid, de tweede snede was direct nodig als groenvoer. In september en oktober was er bijna geen weide meer, zoals overal het geval was. In de vrije koloniën was van bijna 40 ha bemest nieuw klaverland $89.000 \mathrm{~kg}$ hooi verkregen. Voor de 7 maanden vanaf oktober moest men een recordhoeveelheid van $1.425 .000 \mathrm{~kg}$ aankopen, hoofdzakelijk van Genemuiden en Kuinre. Voor Wateren was in dit jaar ook hooi van buiten nodig, n.l. $147.000 \mathrm{~kg}$ tegen een eigen produktie van $41.000 \mathrm{~kg}^{217}$.

Bij de Staat van den Hooi-Oogst in 1848 merkte de directeur in verband met de geringe eigen hooiwinning op: „De oppervlakte groenland is dan ook te klein en hetzelve 218 wordt met vier jaren te lang gehouden. Het wordt daarbij afgeweid, dat meer lands vordert dan de stalvoedering met afgemaaid groenvoer."

Omstreeks het midden van de I 9 de eeuw deed men allerwegen aanbevelingen ten gunste van de zomerstalvoedering. Deze werkwijze heeft als voordelen:

I. geen grasverlies door vertrappen;

2. tijd- en materiaalbesparing wegens het vervallen van het slaan van flatten, de drinkwatervoorziening, het melken en de afrastering in resp. van het weiland;

3. betere contrôle op het vee;

4. betere gezondheid van het vee;

5. grotere stalmestproduktie;

6. grotere veestapel per roo ha grasland.

Als nadeel noemt men tegenwoordig echter, dat bij zomerstalvoedering in totaal meer arbeid nodig is.

In een recent literatuuroverzicht over dit onderwerp wordt gezegd: 
„De eerste keer, dat stalvoedering, of „soiling”, zoals het in Engeland heette, in de buitenlandse literatuur genoemd werd, was in 18 I 2 . Nadien raakte deze voedermethode in verval, terwijl zij thans vooral in Amerika en Engeland en ook in Frankrijk weer in de belangstelling komt te staan."

Van der Poel heeft echter aangetoond, dat de zomerstalvoedering in België reeds in de 18 de eeuw werd toegepast, zoals blijkt uit vermeldingen in de Duitse literatuur, die omstreeks 1800 is verschenen ${ }^{219}$.

Ging de Maatschappij, ondanks de adviezen, niet over tot uitbreiding van de rundveestapel, het Algemeen Verslag over i 849 vermeldt, dat de vergroting van het aantal schapen voor de vetweiderij des zomers één aanbeveling was, die wel in praktijk werd gebracht. Inderdaad had deze vergroting plaats in $\mathrm{I} 85 \mathrm{I}$.

De directeur zei in dit verband over Wateren, dat men door uitbreiding van de schapenhouderij (ook vanwege de mestproduktie) en door verbetering van het groenland door begreppelen en beaarden wilde trachten in de eerste plaats te zorgen zelf het benodigde hooi te winnen. In $185 \mathrm{I}$ was voor het vee te Wateren echter nodig 277 voer hooi à 1000 oude of $500 \mathrm{Ned}$. ponden $(=500 \mathrm{~kg}$ ), terwijl men ter plaatse slechts 74 voer had kunnen verkrijgen, d.i. ruim een kwart van de behoefte 220 .

Het beoogde doel van zelfvoorziening in de hooibehoefte heeft men te Wateren niet kunnen bereiken. Zo leest men in de Algemeene Oogststaat van I 856, dat voor de winter I 856/57 nog een groot deel van het voor Wateren benodigde hooi moest worden aangekocht, n.l. voor bijna $f 2200$, - . In de gewone koloniën was de toestand nog veel ongunstiger. Bijna alle hooi werd gekocht voor ruim $f$ i 5.300, 一.

Hier had men alleen in kolonie I de beschikking over I I ha blijvend groenland in het Broek en op de kampen bij Niënkemper en Matena. Met de 302 ha kunstweide in de drie koloniën verkreeg men dus veel te weinig wintervoer voor de 475 melkkoeien 221 .

Er was nog niet voldoende tot I december, doordat i 857 een „zeldzaam droog jaar" was. Als wintervoer werd 3800 mud krielaardappelen gebruikt en \pm I 200 voer gekocht hooi; de grootste helft was licht hooi van Zuidveen en Giethoorn tegen $f$ 8,50 per voer, de kleinste helft zwaar hooi van Kuinre à $f$ i 4 ,- - per voer aankoopprijs. Inclusief transportkosten moest de Maatschappij $\pm f$ i $5.000,-$ an hooi besteden, bijna evenveel als in 1856 . De vervoerde aardappelen hadden een waarde van $\pm f 3000$, - zodat één rund aan wintervoer $f_{3} 6,50$ had gekost. Voor Wateren moest men 280 voer hooi aankopen ${ }^{222}$.

Ook $185^{8}$ was een droog jaar met weinig gras en hooi. Om de dure voeraankopen tot het hoogstnodige te kunnen beperken had men in ge- 
deeltelijk nieuw gebouwde „kookhuizen” veevoer gekbokt, dat bestond uit aardappelen en stro. Naar de mening van Mackay, de gecommitteerde van de regering, zou men dit ook in volgende jaren kunnen voeren ${ }^{223}$.

Het is hier wellicht de meest geschikte plaats om iets mee te delen over de bijenteelt, op de zandgronden vroeger een veel voorkomend bedrijfsonderdeel. Reeds in 1825 deed een Amsterdamse waskaarsenfabrikant de Permanente Commissie de aanbeveling in de koloniën op grote schaal over te gaan tot bijenhouderij volgens een nieuwe methode (met magazijnkorven). Er was eerder al een goed geslaagde kleine proef genomen. Men besloot de bijenteelt langzamerhand verder in te voeren onder deskundige leiding 224. Hierover verneemt men in de latere archiefstukken echter niets meer.

Tot slot van deze paragraaf over het grasland en de veestapel ligt de conclusie ten aanzien van dit gedeelte van het landbouwbedrijf in de koloniën voor de hand. Of de veestapel nu in bepaalde jaren groter of kleiner was, hij had voortdurend een te grote omvang in verhouding tot de oppervlakte tijdelijk en blijvend groenland. Bovendien nam de opbrengstwaarde van het klaver- en grasland met het verstrijken van de jaren af door een te geringe mestvoorziening; dit geldt uiteraard ook voor het bouwland. Hieruit resulteerde een stijgende behoefte aan aangekocht ruwvoeder in de vorm van hooi. Deze aankopen waren een permanente belasting van de financiële huishouding van de Maatschappij, die steeds zwaarder drukte en uiteindelijk bijdroeg tot de noodzaak van de algehele reorganisatie in 1859 .

Directeur Van Konijnenburg noemde voor de jaren vóór I 859 een algemeen financieel tekort op de huishouding van de gewone koloniën van $f 50.000,-\operatorname{tot} f 60.000,-$ jaarlijks, d.i. $f$ i $20,-\operatorname{tot} f$ I $40,-$ per kolonistengezin 225 . Volgens een berekening van zijn opvolger zou het verlies op de sector veehouderij per jaar $f 20.000$, - hebben bedragen ${ }^{226}$.

\section{DE BOSBOUW}

In tegenstelling tot de akkerbouw is de bosbouw in de gewone koloniën en te Wateren van I 8 I 8 tot 1859 slechts van geringe betekenis geweest. Westendorp Boerma merkt in dit verband op, dat pas na 1830 een grotere bedrijvigheid op bosbouwgebied valt waar te nemen ${ }^{227}$. Elders is echter reeds aangeduid, dat ook na $183^{\circ}$, althans in de gewone koloniën, weinig of niets van importantie is verricht ten aanzien van de bosbouw ${ }^{228}$. De enige angekochte bossen (o.a. het Sterrebosch) bevonden zich in de eerste koop van onroerend goed, waardoor de Maat- 
schappij eigenaresse werd van het huis Westerbeeksloot en bijbehorende goederen. Zelfs is een areaal bosgrond van $62 \mathrm{mg}$, dat hiervan deel uitmaakte, verminderd tot $46 \mathrm{mg}$ omstreeks $\mathrm{8} 830$. De Maatschappij bezat toen 39 ha bos in de gemeente Vledder, 7 ha in Weststellingwerf en 3 ha in de gemeente Smilde (tabel 2).

Van de aanleg van bos door ontginning van heidegrond is tot 1859 in nog mindere mate sprake geweest. Aansluitend aan het Sterrebosch is echter in 1832 een oppervlakte van \pm 6 ha heide bebost met gewone grove den, die zeer goed opkwam. Van de oorspronkelijke plannen van Van den Bosch op elke kolonistenhoeve (van $3 \mathrm{mg}$ ) I $\mathrm{mg}$ te bestemmen tot sparrenbos is niets gekomen.

In 1823 pleitte Jan Kops reeds voor beplanting van de brede wegen in de gewone koloniën met Canadese populieren, die goed klompenhout konden leveren. Blijkbaar waren toen niet veel laanbomen aanwezig. Wel stonden bij de meeste hoeven al enkele bomen ${ }^{229}$.

De anonieme criticus 230 van i 828 sprak zelfs van een "gehele verwaarlozing van het aanleggen eener boomkwekerij zoo wel als van de beplanting der houtwallen". Dit was z.i. één van de veelvuldige bewijzen van het „zeer oppervlakkig nadenken over de middelen van ontginning en vruchtbaarmaking der heigronden". Houtwallen om de hoeven zouden de lucht verwarmen en meer regen veroorzaken ${ }^{23 x}$. Er waren wel enkele beplante houtwallen in de koloniën, maar de bomen waren op de vaste grond gepoot. Om de hoeven stonden geen iepen of populieren. De Permanente Commissie tekende bij deze kritiek echter aan, dat in kolonie II (Frederiksoord) een boomkwekerij was ingericht.

Deze kwekerij begon in 1833 materiaal af te leveren. Voor de eerste maal treft men n.l. in het Algemeen Verslag over I 833 een opsomming aan van de aantallen bomen, die in de gewone koloniën waren gepoot langs de wegen, o.a. de weg Frederiksoord - Vledder. Het betrof hier 200 grote Amerikaanse populieren, 4000 kleine dennen, I6.500 eiken, 17.000 elzen en 38.000 berken. De populieren waren gekocht, de overige soorten waren voor $4 / 5$ gedeelte afkomstig uit de eigen kwekerij. Het ging hier dus uitsluitend om laanbomen.

In Wateren deed men doorgaans iets meer aan de eigenlijke bosbouw dan in de gewone koloniën. Zo is in 1840 "een groote hoek gronds" ten noorden van het gesticht bepoot met 6000 eiken "duimstekken”, die echter slecht aansloegen. Waarschijnlijk waren de gekochte stekken te lang uit de grond geweest. In het najaar ging men daarom opnieuw beplanten met zelfgekweekte berken en eiken ${ }^{232}$.

Ook ging men hier in de winter van $x 842$ op I 843 op gedempte sloten 
tussen akkers bouwland op een onderlinge afstand van 18 roeden 10 houtwallen aanleggen, die I $\mathrm{r}$. breed waren en een totale lengte van $840 \mathrm{r}$. hadden. Volgens het Algemeen Verslag over I 842 waren zij „zeer doelmatig aangelegd" met aan weerszijden een greppel. 25.000 stuks berken- en eikenplantsoen waren hiermee gemoeid. Ook bij het Instituut te Wateren was een boomkwekerij, die in de herfst van 1842 is uitgebreid met één mg geëgaliseerde en begreppelde grond, waarop meer dan 3o mud eikels was gepoot.

Tenslotte is men in het begin van de jaren veertig tevens in kolonie III (Willemsoord) met een kwekerij van berken en elzen begonnen. De pootplanten dienden steeds hoofdzakelijk voor de aanleg van heggen en wallen en voor erfbeplanting. In I 843 b.v. zijn 80.000 boompjes uit de kwekerij van kolonie III uitgepoot ${ }^{233}$.

Uit het feit, dat Staring en Quarles van Ufford in hun rapport, samengesteld na hun bezoek in 1846 , drie bladzijden wijdden aan de houtteelt, kan men afleiden, dat zij betrekkelijk veel waarde hechtten aan de bosbouw. Hoewel zij opmerkten, dat deze „tak van landbouw” in de gewone koloniën in de laatste jaren aanmerkelijk was vooruitgegaan, maar te Wateren nog zeer achterlijk was, oordeelden zij in het algemeen, dat de bosbouw voor meer uitbreiding vatbaar was. Tot dusver had deze bedrijfstak meest uit proefnemingen bestaan. De elzenheggen vormden het enige gewas, dat goede resultaten opleverde. Maar men moest jaarlijks grote sommen uitgeven aan timmer- en werkhout, doordat dennen, eiken, beuken en bomen voor klomphout vrijwel alleen in kleine proefbosjes aanwezig waren. De grond achtte Staring ,volmaakt geschikt" voor deze en andere houtsoorten.

De toenmalige directie van de koloniën was onvoldoende op de hoogte van de bosbouwwetenschap; Staring drong dan ook aan op de aanstelling van een adjunct- of onderdirecteur voor de bosbouw. De grond moest beter worden bewerkt. Een tweede gebrek was het ontbreken van beschermende dennensingels voor de omheining van tuinen en akkerland. Staring vond het „onbegrijpelijk, dat men niet vroeger bedacht is geweest op de leer der landontginners in Gelderland, wier eerste handeling bij het aanvaarden van woeste heidevelden, onveranderlijk is het zaaijen van dennen en het aanleggen van dennensingels tot windbrekers"234.

Hierop repliceerde het bestuur van de Maatschappij in het Algemeen Verslag over 1847 , dat in de kwekerijen in de gewone koloniën jaarlijks 80.000 - 100.000 zaaielzen en -berken werden gepoot, die men had verzameld in de koloniën of gekocht voor $f 0,75$ per ı 000 . Na I à 2 jaar hadden zij een waarde van $f_{3}$,- per roo०. Zij werden uitgeplant in 
houtwallen en heggen, b.v. de houtwal langs de Vledderweg in Frederiksoord door de zandverstuiving. Aan bosbouw in het groot deed men vrijwel niets, omdat men geen geschikte grond kon onttrekken aan de cultuurgrond of de heide, die als schapenweide moest dienstdoen. De adviezen van Staring werden dus in de wind geslagen.

De volgende deskundige, die de koloniën in 1848 bezocht, de Groninger hoogleraar Van Hall merkte over de houtteelt alleen op, dat de houtwallen dienden te worden uitgebreid. De Permanente Commissie antwoordde, dat men hiermee sinds jaren bezig was 235 .

Toch trok het bestuur van de Maatschappij zich blijkbaar wel iets aan van het pleidooi van Staring c.s. tot uitbreiding van de eigenlijke bosbouw. In I 849 werd $\frac{1}{2}$ ha heideveld ten zuidoosten van het gesticht te Wateren diepgespit en beplant met verschillende houtsoorten. Dit was dus waarschijnlijk een proefneming. Ook bezaaide men hier een $\frac{1}{2}$ ha heide met grove den, terwijl een hooggelegen akker werd omgeven met een houtsingel van 225 fijne dennen tegen het stuiven ${ }^{236}$.

Tenslotte maakt ook het Algemeen Verslag over i 852 melding van een begin van bosbouw ter beteugeling van de zandverstuivingen in kolonie vII. Aan het einde van de derde wijk van kolonie II (Wilhelminaoord), bij de Doldersummerduinen, is in dit jaar I ha heide begreppeld en bezaaid met dennenzaad om t.z.t. jonge dennen te verkrijgen voor de beplanting van de duinen. Ook is in 1852 voor de eerste maal hout verkocht, n.l. een aantal populieren, die het bouwland nadeel berokkenden en $f 282,50$ opbrachten.

De bosbouw is eerst op enigszins grote schaal op gang gekomen na I 859 . Zo is vanaf 1862 in kolonie vII bijna 200 ha bezaaid met dennenzaad. Ook in Frederiksoord, Wilhelminaoord en Willemsoord zijn bossen aangelegd, w.o. ook larix. De nieuwe eigenaren van Wateren en omgeving gingen ook hier de bosbouw na I 860 in het groot uitvoeren ${ }^{237}$. 


\section{ENKELE SOCIALE ASPECTEN VAN DE LANDBOUWKOLONIËN}

\section{ARBEIDSVERHOUDINGEN IN DE LANDBOUW}

$\mathrm{Z}$ oAls hiervoor reeds is opgemerkt, bestaat een nauw verband tussen de arbeids- en de pachtverhoudingen. Laatstgenoemd onderwerp is behandeld in hoofdstuk III, 5, waar tevens enige bijzonderheden zijn medegedeeld over de arbeidsverhouding, zoals deze zich heeft ontwikkeld tussen de Maatschappij van Weldadigheid enerzijds en de kolonistenarbeiders resp. de vrijboeren anderzijds. In deze paragraaf zullen nog enkele nadere gegevens betreffende de landbouwarbeid in de koloniën worden vermeld. Voor het overige zij verwezen naar de paragraaf over de pachtverhoudingen.

Van den Bosch heeft in zijn eerste Verhandeling aan het Nederlandse volk kenbaar gemaakt, dat het verrichten van arbeid de belangrijkste pijler diende te zijn, waarop de landbouwkoloniën zouden rusten: "Arbeid derhalve, arbeid alleen, kan als een geschikt middel worden aangemerkt, om de armoede te bestrijden; en ieder geschikt middel behoort te worden beproefd om die talrijke klasse van menschen, die door toevallige of andere opgesomde oorzaken uit den arbeidenden kring zijn uitgestoten, daarin op nieuws eene plaats te doen vinden" ${ }^{\text {. }}$

Als één der moeilijkste zaken beschouwde hij de opleiding van de armen tot arbeidzaamheid; de ontginning en bebouwing van de doorgaans schrale gronden zouden een moeilijke en zware arbeid betekenen voor de kolonisten. Met name de bedelaars zouden eerst aan lichtere arbeid moeten worden gewend, die tevens geschikt zou zijn voor de vrouwen als aanvullende inkomstenbron, wanneer man en zoons de landarbeid leerden. Als zodanige arbeid noemde Van den Bosch het spinnen van vlas en wol tot garen en sajet en het weven van linnen ${ }^{2}$.

De generaal achtte de arbeidskrachten van één gezin voldoende om I mg grond met handenarbeid zonder paardewerk te kunnen bebouwen. Hij begrootte b.v. de arbeidsbehoefte voor I $\mathrm{mg}$ aardappelen op : 


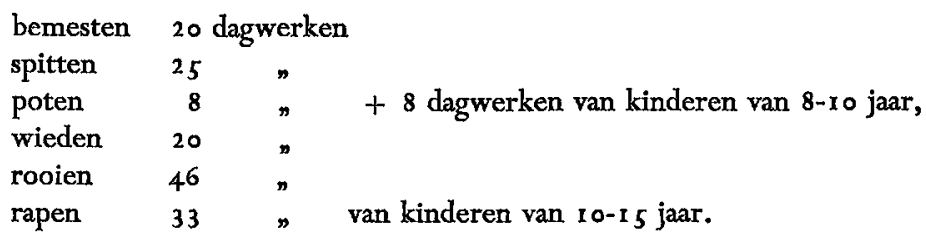

Totaal benodigd I 70-1 80 dagwerken (incl. naar huis brengen van de oogst), waarvan 4I dagwerken door kinderen.

De totale oogst van 200-250 zakken aardappelen met een waarde van $\pm f 300,-$ zou voldoende zijn voor het onderhoud van een gezin ${ }^{3}$. De kolonist zou volgens deze berekening dus maximaal 140 dagwerken of 28 weken landbouwwerk moeten verrichten. De zaterdagen moest hij besteden aan de mestbereiding en zijn eigen z.g. tuinstuk. Wat hij in de overige 24 weken te doen zou hebben, vermeldde Van den Bosch echter niet. Het is zonder meer duidelijk, dat $\mathrm{r} \mathrm{mg}$ cultuurgrond onvoldoende arbeidsgelegenheid biedt aan een gezin. In werkelijkheid werd dan ook per gezin $3 \mathrm{mg}$ bebouwd.

Het was de bedoeling, dat de kinderen van de kolonisten na hun opleiding buiten de koloniën zouden gaan werken. De jongens konden de duizenden vreemde landarbeiders vervangen, die jaarlijks gedurende ongeveer drie maanden tegen hoge daglonen bij Nederlandse boeren werkten. Ook achtte Van den Bosch de kolonistenzoons bijzonder geschikt voor de krijgsdienst en de dochters voor boerendienstboden ${ }^{4}$. De kinderen konden hun ouders dus niet opvolgen als kolonisten op de hoeven.

Alleen werkwilligen wenste de generaal in de koloniën op te nemen. Een behoorlijke discipline was nodig, te verzekeren door een systeem van toezicht, bij voorkeur door oud-gedienden met een (te) klein pensioen aan te stellen als ambtenaren, b.v. onderofficieren en soldaten uit de landbouwende stand. Bij nalatigheid en niet opvolgen van billijke bevelen kon men een geldboete heffen door inhouding op het loon van de vrouwen. Anderzijds zouden de ijverigsten worden aangemoedigd door premies, te bekostigen uit de ontvangen boetes. "Geheel onwilligen en wederspannigen, of zedeloozen, behooren te worden weggejaagd", d.w.z. zij zouden voor enige tijd worden opgesloten in een Rijkswerkhuis, tot zij zich hadden gebeterd5. Aldus meende Van den Bosch door een uniform werkprogramma onder streng toezicht, op militaire leest geschoeid, de kolonisten tot een arbeidzaam leven te kunnen brengen.

Eilerts de Haan heeft een lezenswaardige beschrijving gegeven van de 
wijze, waarop de landarbeid in de koloniën was geregeld. Hieraan is het volgende ontleend 6 .

De wijk- en sectiemeesters werden in het algemeen geselecteerd uit de beste kolonisten. De sectiemeesters leerden de kolonisten de landbouwwerkzaamheden, terwijl de wijkmeesters met het toezicht waren belast, het tijdstip van aanvang en einde van het werk aangaven en het loon berekenden volgens het geldende tarief. De loonberekening gebeurde aanvankelijk zeer nauwkeurig, omdat het loon afhankelijk was van de verrichte hoeveelheid arbeid overeenkomstig het beginsel : „Die niet arbeidt, zal niet eten."

Het bleek echter al gauw, dat niet alle kolonisten de lust hadden of in staat waren tot regelmatige arbeid.

Daar de Maatschappij deze kolonisten en hun gezinnen niet kon laten verkommeren, voerde zij in 1822 het systeem van minimum- en maximum-lonen in onder de leuze: „De Maatschappij zal $U$ voeden en kleeden voor den arbeid, dien gij verricht." Dit stelsel bleef tot I 859 van kracht.

De werkzaamheden bestonden uit ontginnings- en landbouwwerk; in de herfst, winter en lente had men tijd beschikbaar voor het graven van vaarten en sloten, onderhoud van wegen en werk in de bossen of het veen.

De ingewikkelde regeling van de verplichte betalingen in natura en looninhoudingen, die vanaf $\mathrm{r} 822$ ten laste van de kolonisten kwamen, is reeds elders vermeld 7 . Alle betalingen en inhoudingen werden aangetekend in een zakboekje of livret. Wat van het arbeidsloon overbleef, werd in geld uitbetaald en diende als winkelgeld voor het doen van aankopen in de „koloniale” winkels. Toen bleek, dat sommige kolonisten buiten de koloniën sterke drank kochten, waarvan het gebruik in de koloniën niet was toegestaan, ging de Maatschappij eigen geld uitgeven, dat alleen in de koloniën was te gebruiken. Tot 1859 is de z.g. koloniale munt in omloop geweest.

Het gemeenschappelijke landbouwwerk begon 's zomers om 6.00 uur, 's winters om 7.00 uur, en eindigde 's middags om 16.00 uur. Om 5.00 resp. 6.00 uur gaf de wijkmeester met een bel het sein voor de reveille; een uur later gaf het gelui het tijdstip aan van het appèl voor het huis van de wijkmeester. Hoewel men overwegend handenarbeid verrichtte, had elke sectie aanvankelijk een paard of os voor het ploegen. Men rekende, dat de kolonisten niet meer dan $2 / 3$ gedeelte van de arbeidsprestatie van een gewone landarbeider konden leveren ${ }^{8}$.

Het minimale dagloon is in 1822 vastgesteld op 6 pond roggebrood, $\frac{1}{2}$ schepel aardappelen en $f$ o, 18 per gezin. Hierbij had men dan de op- 
brengst van de koe en de eigen groentetuin. Had men minder verdiend, dan werd het tekort als schuld aan de Maatschappij in het betaalboekje bijgeschreven. Het gevolg was, dat vele kolonisten hun schuld voortdurend zagen aangroeien, al dan niet tegen hun zin. Men was verzekerd van de eerste levensbehoeften, ook wanneer men niet kon of wilde werken. Anderzijds droeg de invoering van een maximum-loon niet bij tot vergroting van de inspanning van de kolonisten. Hetgeen meer was verdiend dan het maximaal vastgestelde bedrag, werd in het boekje tegoedgeschreven als een reservefonds voor tijden van tegenspoed. Het aanvankelijk ingevoerde systeem van tarief- of accoordloon (loon naar werken) werd dus tweezijdig geweld aangedaan.

Von Grouner vermeldde, dat ook kinderen van 6 en 7 jaar in drukke tijden in accoordloon werkten. Zij moesten per week minstens $f \circ, 3^{\circ}$ verdienen. In juni en juli ging men wel heideplaggen steken, waarmee een man per dag soms $f \circ, 5 \circ$ of $f \circ, 60$ kon verdienen (wederom in accoord), een jongen van 12 jaar $f \circ, 3 \circ$ tot $f \circ, 45$. Men kan echter niet stellen, dat de kolonisten-arbeiders volledig in loondienst waren bij de Maatschappij, daar zij ieder afzonderlijk moesten betalen voor de door anderen verrichte arbeid. Kochten zij van de Maatschappij turf, dan betaalden zij de daarin begrepen loonsom terug aan de Maatschappij. Elke kolonist-arbeider moest op dezelfde wijze aan de directie het loonbedrag restitueren, dat andere kolonisten hadden verdiend door op zijn hoeve in ploegverband landarbeid te verrichten. Deze verrekening had plaats via het Fonds voor den Veldarbeid, waarin een kolonist-arbeider jaarlijks $f_{50},-$ moest storten in natura ${ }^{9}$. Al droeg ook de Maatschappij zelf wel bij tot genoemd fonds, toch krijgt men uit deze regelingen de indruk van een collectivistische structuur.

De bekwaamste kolonisten konden opklimmen tot vrijboer (pachter), werden soms bevorderd tot wijkmeester of als bouwboer geplaats op de grote boerderijen te Veenhuizen of Ommerschans. Onwilligen en luiaards werden daarentegen wel verlaagd tot kolonist-arbeider te Veenhuizen (zuiver dagloner) of bij wangedrag opgezonden naar de strafkolonie te Ommerschans ${ }^{10}$.

Wardenburg heeft in 1828 vrij veel aandacht besteed aan de onderwerpen arbeid en loon. In zijn brochure schreef hij onder het hoofd „bewerking van den grond", dat deze bijna uitsluitend met de spade gebeurde I . Naar zijn mening zou men een grotere opbrengst verkrijgen door herhaald ploegen. In dit verband haalde hij de schrijvers Serrurier en Thaer aan. Bovendien maakte het spitten z.i. de landbouw kostbaar, hetgeen noch in het belang van de Maatschappij, noch in dat van de 
kolonisten was, die de levensmiddelen duurder moesten betalen. Het spitloon bedroeg in de koloniën $f 0,02 \frac{1}{2}$ per roede of $f 15$,- per $\mathrm{mg}$. Voor dit bedrag kon men de grond volgens Wardenburg zeker driemaal ploegen en zesmaal eggen. De vele handen had de Maatschappij beter kunnen gebruiken voor de ontginning van meer woeste grond.

In haar antwoord op deze aanmerkingen gaf de Permanente Commissie als haar mening weer, dat de kolonisten de gewone arbeidsmarkt niet mochten benadelen. $\mathrm{Zij}_{\mathrm{ij}}$ moesten dus in de koloniën voldoende arbeid kunnen vinden. $\mathrm{Na}$ de ontginning met paarden maakte de Maatschappij in de landbouw derhalve alleen gebruik van handenarbeid. Het lijdt m.i. echter geen twijfel, dat de dichte arbeidsbezetting een belangrijke oorzaak was van de financiële tekorten.

Wardenburg haalde vervolgens in zijn brochure onder de titel „middelen van bestaan der kolonisten" uit de Huishoudelijke Bepalingen aan, dat een gezin na drie jaren een inkomen van $f_{400,}-\operatorname{tot} f_{525}$, per jaar zou kunnen verwerven. Dit was volgens hem in strijd met de werkelijkheid: in r 828 bedroeg de gemiddelde schuld enkele honderden guldens per gezin. Voor de directie leverde de landbouw onvoldoende overschotten op om door verkoop de aankopen van mest, veevoer, zout, zeep etc. te kunnen betalen. Naar de mening van deze criticus was geldgebrek de aanleiding tot de invoering van de koloniale munt en de oorzaak van het feit, dat in de koloniale winkels "meestentijds het nodige ontbreekt”. Sterke drank konden de kolonisten z.i. toch wel krijgen door ruiling van levensmiddelen.

Het bestuur van de Maatschappij deelde in haar beantwoording van Wardenburgs brochure mee, dat de arbeidsongeschikheid van een aantal gezinshoofden noopte tot kostbare paardenarbeid en het aantrekken van vreemde arbeidskrachten ${ }^{12}$. De samenvoeging van de oorspronkelijke zes koloniën tot drie gaf een bezuiniging op het ambtelijke apparaat, evenals het aanstellen van ambtenaren uit de kolonisten zelf en het ontslaan van ongeschikte beambten (waaronder de anonieme schrijver van de „Vlugtige waarnemingen”).

De vergelijking, die deze had getrokken tussen het minimum gezinsinkomen van $f 400$, - en de gemiddelde opbrengst van de oogst der $37 \mathrm{I}$ hoeven in 1825 , was volgens de Permanente Commissie onjuist. In de Huishoudelijke Bepalingen was sprake van het inkomen, niet van de oogstwaarde. De P.C. becijferde het gezinsinkomen op $f 7,3^{8}$ gemiddeld per week of $f_{38}{ }_{3,76}$ per jaar, dus niet veel minder dan het gestelde minimum. Hierin waren tevens begrepen de inkomsten uit de "fabriekmatige arbeid" 
(weven b.v.) en alle verdiensten van bakkers, kleermakers, schoenmakers, timmerlieden, spinners, wevers enz.

Tenslotte vond Wardenburg, dat de kolonisten te weinig verdienden. De daglonen in de omgeving (gemeente Diever en Vledder) bedroegen 's zomers $f \circ, 8 \circ$, 's winters $f \circ, 4^{\circ}$. De directie der Maatschappij zou teveel op de lonen korten. Bij aangenomen werk konden dagloners in alle omstreken van de koloniën wel $f 6,-\operatorname{tot} f 8,-$ per week verdienen in de zomer en $f 2,5 \circ$ tot $f 5$, - 's winters. Het minimum weekloon van de kolonisten was echter (in geld uitgedrukt) bepaald op $f 4,8 \circ$, het maximum op $f 6, \mathrm{I}^{13}$, zodat men niet kan concluderen, dat de lonen in de koloniën in het algemeen lager waren dan daarbuiten. Hoewel dit 's zomers inderdaad wel het geval was, stond hiertegenover, dat de verdiensten in de koloniën 's winters gemiddeld hoger waren dan in de omgeving.

Zoals reeds meermalen is vermeld, voerde het bestuur van de Maatschappij in 1836 op instigatie van Van den Bosch belangrijke veranderingen in ten aanzien van de structuur van de vrije koloniën. Ook voor de arbeidsverhoudingen had deze reorganisatie een aantal ingrijpende gevolgen, waarover de generaal het een en ander meedeelde in zijn derde verhandeling ${ }^{\mathrm{I}}$.

In de tweede afdeling merkte hij op onder het hoofd „Verdeeling van den arbeid": „Zoo er iets gebrekkigs bestaat in de inrigtingen van de Maatschappij van Weldadigheid, is het voorzeker in de verdeeling van den veldarbeid, zonder dat zou men niet zoo zeer klagen over gebrek aan handen ter verdere uitbreiding van de kultures."

Ter bepaling van de arbeidsbehoefte baseerde Van den Bosch zich op het werk van Thaer. Na de reorganisatie raamde hij het arbeidsaanbod per sectie van 36 ha op I 2 mannen en jongens van i 5 jaar en ouder, zijnde het aantal "werkbare handen" voor de landbouw. Dit aanbod achtte hij voldoende voor de behoefte.

De verschillende werkzaamheden werden in vier perioden ingedeeld, te rekenen vanaf $\mathrm{x}$ november:

eerste periode: 70 dagen voor het plukken van bremzaad en het spitten van $7 \mathrm{mg}(=6 \mathrm{ha})$ één steek diep;

tweede periode: 86 werkdagen (tot Io mei) voor het spitten van I mg bremgrond, het klaarmaken en inzaaien van $3 \mathrm{mg}$ vlas, het poten van $8 \mathrm{mg}$ aardappelen en overmesten van $6 \mathrm{mg}$ klaver; 
derde periode: 72 dagen voor de roggeoogst van $14 \mathrm{mg}$ en het oogsten en roten van $3 \mathrm{mg}$ vlas; de resterende tijd te besteden aan turfgraven en andere arbeid;

vierde periode: 76 dagen voor het rooien van $8 \mathrm{mg}$ aardappelen (1 2 arbeiders in 3 dagen $\mathrm{I} \mathrm{mg}$, indien alle huisgenoten en aankomende kinderen raapten), het klaarmaken en inzaaien van $14 \mathrm{mg}$ rogge met brem en het onderspitten van $3 \mathrm{mg}$ brem. Dit laatste gebeurde greppelsgewijs door een greppel te spitten van I steek diepte, de ondergrond I steek diep om te spitten, de greppel met de bremplanten te vullen en te bedekken met de eerste steek aarde, zodat de bovengrond steeds boven bleef.

Op deze wijze waren de werkzaamheden verdeeld over de 304 werkdagen van het jaar. Het hooien van klaver en ander werk op de hoeven moest door de afzonderlijke gezinnen gebeuren. Het onderploegen van de mest op het roggeland en het ineggen van zaad had plaats met behulp van trekarbeid door ossen of paarden. Al het overige was handenarbeid.

Het gemiddelde arbeidsloon stelde Van den Bosch op $f$ 0,50 per dag voor de veldarbeid. Het andere werk, zoals dorsen, vlas roten en turf steken, inbegrepen kon elk valide gezin per jaar $f 234,-$ verdienen (per week $f 4,5^{\circ}$ ). Bovendien kon het uit fabrieksarbeid $f^{2}$,- - per jaar verkrijgen, terwijl het tevens de opbrengst van de koe ontving ter waarde van $f 3 \circ$, - Aldus raamde Van den Bosch het gemiddelde jaarloon per

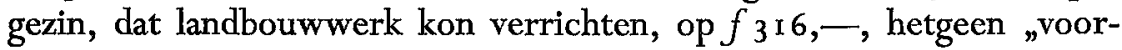
zeker als een ruim inkomen voor een arbeidershuisgezin kan worden beschouwd". Men had immers vrij wonen en turf voor het steken. De Maatschappij bekostigde verder, naast de administratie, het onderhoud van de huizen, het school- en godsdienstonderwijs en de geneeskundige hulp. Hiervoor moest de kolonist per jaar afdragen resp. $f_{2}, 5^{\circ}, f_{1} 0,-$ en $3 \times f 2,50$, dus $f 20,-$ per gezin.

Van het door de landarbeid verdiende weekloon van gemiddeld $f 4,5 \circ$ werd ingehouden: $f \mathrm{r}$, - voor het verstrekte brood, $f \mathrm{r},-$ voor de verstrekte aardappelen en $f \mathrm{I}, 5$ o voor de kleding. De resterende $f \mathrm{I}$, per week werd als winkelgeld uitbetaald. Indien een gezin uit de veldarbeid in een week meer $\operatorname{dan} f 6$, - verdiende, zou het meerdere worden tegoed geschreven als een reserve voor uitkering bij mindere verdiensten in de slappe tijd. Een soort verplichte spaarregeling dus (zonder rentevergoeding).

$\mathrm{Na}$ de invoering van bovengenoemde regelingen werd in. 1839 nog bepaald, dat de kolonisten-arbeiders in de gewone werkuren geen arbeid 
buiten de koloniën mochten verrichten. Dit om te verzekeren, dat alle arbeidskrachten voor de Maatschappij behouden bleven ${ }^{15}$. Hieruit kan men de conclusie trekken, dat de arbeidslonen buiten de koloniën naar alle waarschijnlijkheid hoger waren. Sedert r $84^{\circ}$ was het wiel aan de vrijboeren toegestaan met hun gezinsleden buiten de koloniën te gaan werken.

Overigens hadden de landbouwwerkzaamheden op dezelfde wijze plaats als voorheen. De arbeiders-kolonisten verrichtten de veldarbeid gemeenschappelijk gedurende vijf dagen per week onder leiding van de wijkmeesters. Op de zesde dag hadden de kolonisten vrij voor de verzorging van hun eigen tuinen, waarvoor zij geen loon ontvingen. De sectiemeesters werden in $184^{\circ}$ niet meer genoemd ${ }^{16}$. Elke kolonie van omstreeks roo hoeven stond onder het toezicht van een onderdirecteur met 3 of 4 wijkmeesters en evenveel opzichters-kolonisten. De kinderen namen vanaf de leeftijd van dertien jaar deel aan het werk; tot de vijftienjarige leeftijd waren zij echter wel verplicht het avondonderwijs te volgen. De vrijboeren waren geheel voor eigen rekening werkzaam, hoewel zij in behoeftige omstandigheden door de Maatschappij werden gesteund.

De Staatscommissie van I 84I was van mening, dat het teveel aan handenarbeid en het geringe aantal werktuigen één van de hoofdgebreken vormden van het landbouwstelsel in de koloniën. De arbeidslonen te Wateren achtte de commissie te hoog. Als oorzaak noemde men de stelregel, dat elke oppassende jongen dit Instituut op twintigjarige leeftijd moest kunnen verlaten met een tegoed van $f 25,-\operatorname{tot} f 3^{\circ}, \mathbf{1}^{17}$.

De financiële positie van de Maatschappij noopte in 1844 tot enkele nieuwe bezuinigingsmaatregelen. Zo werd het minimumloon voor kinderen tot en met 14 jaar verlaagd met enkele centen per week ten aanzien van het winkel- en kledinggeld, „zonder dat daardoor het noodige voor levensonderhoud te zeer werd beperkt" ${ }^{\prime 18}$. Niettemin beklaagden de kolonisten zich over deze maatregelen. De broodprijs was echter niet verhoogd en sinds 1842 vastgesteld op $f \circ, 07$ per Nederlands pond $(=\mathrm{kg})$.

Teneinde eenheid in de werktijden te verkrijgen werd in 1845 bepaald, dat 's zomers „de landwerkers even als de fabrykarbeiders” om 5.00 uur moesten beginnen inplaats van 6.00 uur $^{19}$.

Sharing en Quarles van Ufford hebben zich in hun rapport uitvoerig beziggehouden met de arbeidsverhoudingen in de koloniën ${ }^{20}$. Zij wezen er na hun inspectie van 1846 in de eerste plaats op, dat het verschaffen van werkgelegenheid het doel van de landbouw in de koloniën was en de 
verklaring vormde voor de zeer weinige werktuigen en het kleine aantal trekdieren. De in gebruik zijnde schoppen waren echter van ondoelmatige vorm. Een veel steviger en anders gevormd model was volstrekt noodzakelijk. Ook deze beide heren waren van mening, dat te Wateren niet die behoefte bestond aan het verrichten van veel handenarbeid. Het aantal kwekelingen was hiervoor te klein. „... veel tijd en kosten konden er stellig bespaard worden door werktuigen en een grooter aantal trekvee”. Bovendien konden de jongelui dan het gebruik van werktuigen leren.

Staring oordeelde, dat men de kolonisten stellig niet te veel arbeid liet verrichten, terwijl het loon eerder hoger dan lager was, vergeleken met het dagloon buiten de koloniën. Dit laatste in tegenstelling tot de op blz. I 62 vermelde mening. „Elken bezoeker der koloniën, der zake kundig, moet zich steeds verwonderen, hoe het mogelijk is om zulk goed werk te leveren met een troep arbeiders, waarvan men bijna zoude kunnen beweren, dat de beste voor een der slechtsten zal worden gehouden, bij elke verzameling van vrije daglooners." De z.g. aanbesteding van het werk (tariefloon) met voortdurend toezicht kreeg dan ook de volle goedkeuring van Staring.

Hij vond, dat het bouwland, vooral in de gewone koloniën, onvoldoende diep werd geploegd door het gebrek aan trekvee. Eén os moest dikwijls het werk van een driespan doen. Indien mogelijk, raadde Staring aan het roggeland op bedden of smalle akkers te ploegen, waarbij de grond dieper kon worden losgemaakt, het onkruid beter bestreden en het water beter kon aflopen.

Een belangrijk punt van kritiek vormde voor Staring en Quarles van Ufford het systeem van schuldoverschrijving in de gewone koloniën ${ }^{21}$. Elk gezin, dat werd geplaatst op een hoeve, ontving van de Maatschappij kleding, huisraad en gereedschappen op voorschot. De waarde hiervan bedroeg gemiddeld $f 200,-$, welk bedrag het gezinshoofd door inhoudingen op het arbeidsloon moest aflossen in 16 jaar (de z.g. 16-jarige schuld). Dit kon uiteraard alleen gebeuren, als het verdiende loon meer dan het vastgestelde minimumloon bedroeg. In de praktijk zagen vele kolonisten geen gelegenheid (of geen noodzaak) tot aflossing. Door invaliditeit was het ook dikwij]s onmogelijk meer te verdienen dan het minimumloon.

Wanneer nu een hoeve vrijkwam door overlijden, ontslag of ontvluchting, was het regel, dat de schuld van het vertrokken gezin bleef rusten op de hoeve en werd overgeschreven op het nieuwe gezin, dat de hoeve ging bewonen. De totale kolonistenschuld was in 1846 aangegroeid tot $f 300.000$, - en bedroeg voor enkele hoeven zelfs meer dan 
$f 2.000,-$. Het is duidelijk, dat de nieuwe gezinnen zich niet inspanden om een dergelijke aanvangsschuld, buiten hun eigen toedoen ontstaan, te verminderen. Indien zij al hard zouden werken, ontvingen zij toch niets meer dan het minimumloon, omdat de oververdiensten werden ingehouden tot schuldaflossing, hetgeen zeer lang kon duren.

De rapporteurs concludeerden dan ook, dat het onrechtvaardige systeem van schuldoverschrijving geheel verkeerd was, „als uiterst nadeelig werkende op het zedelijk gevoel van zoo vele kolonisten, als bij hen alle energic en werklust uitdoovende, en als niet het minste voordeel aan de Maatschappij aanbrengende." Zij stelden in dit verband voor de oude, overgeschreven schulden te laten vervallen. Hierdoor zouden de energie en werklust van de kolonisten worden bevorderd.

Om dezelfde reden was Staring ook tegenstander van het stelsel van maximumloon ter grootte van $f \mathrm{I}$,- winkelgeld per week per volwassen arbeidskracht (het minimum winkelgeld was $f \circ, 80$ ). Deze maatregel was z.i. strijdig met alle gezonde principes van de economie. Staring hoopte dan ook, dat de financiële toestand van de Maatschappij eenmaal zo zou zijn, dat men ieder kon belonen in evenredigheid tot de verrichte arbeid. In dit verband gaf hij als zijn mening te kennen: „De mensch is zelden geneigd om te werken alleen om het werk zelf en de zekerheid van door zijnen arbeid zijne inkomsten te vermeerderen, is het alleen, die hem in den regel meer werk doet verrigten, dan volstrekt van hem gevorderd wordt." Stellig een uitspraak, die nog steeds van kracht is.

De hoogte der arbeidslonen kan men niet beoordelen zonder ook het prijsniveau van de levensbehoeften in de beschouwing te betrekken. Hierover merkten Staring en Quarles van Ufford op, dat de prijzen, die de kolonisten voor de produkten uit de koloniën moesten betalen (aardappelen, roggebrood), de veranderingen in de marktprijzen niet volgden, hoewel doorgaans ook aardappelen en rogge door de Maatschappij werden aangekocht buiten de koloniën. De prijzen van de overige levensmiddelen en andere winkelwaren werden om de drie maanden vastgesteld met kleine wijzigingen. Doordat de Maatschappij in alle verkoopprijzen $20 \%$ administratiekosten incalculeerde, maakte zij "schijnbaar" grove winsten. Deze schijn kon worden ontzenuwd door de opmerking, dat ook de daglonen in de koloniën hoger waren dan elders. In dat geval pleitten Staring c.s. voor verlaging van prijzen én lonen, waardoor men alle schijn van misbruik zou vermijden en de afscheiding van de koloniën van de z.g. „burgermaatschappij” zou verminderen ${ }^{22}$.

In weerwil van de deskundigheid van Staring op agrarisch gebied 
meende het bestuur van de Maatschappij zijn aanbevelingen niet te moeten volgen. Zelfs betichtte het Staring c.s. van een vijandige gezindheid jegens de Maatschappij! In de arbeidsverhoudingen, de loonregelingen en het systeem van schuldoverschrijving is dan ook tot 1859 geen verandering gebracht, zoals blijkt uit de geschriften van de directeur Van Konijnenburg en zijn opvolger Jongkindt Coninck ${ }^{23}$.

Zo pleitte eerstgenoemde voor invoering van één loonstelsel voor de produktieve arbeid (zonder minimum en maximum), afgestemd op de lonen in de omgeving van de koloniën. Met de maximumloonregeling diende ook het reserveringssysteem te verdwijnen. Wel voelde Van Konijnenburg voor een spaarrekening voor de kolonisten. De gespaarde bedragen zouden echter geheel hun eigendom moeten blijven en worden bestemd voor uitkering bij ziekte, onwerkzaam weer, bevordering tot vrijboer of huwelijk van kinderen. De verstrekking van een gedeelte van het loon in natura wilde hij beëindigen. Ook moesten de kolonisten z.i. volledige vrijheid krijgen elders te gaan werken.

Van Konijnenburg stelde voor op het loon in te houden: $10 \%$ voor de spaarrekening, $\pm 10 \%$ voor de administratie (ambtenarenapparaat, onderhoud gebouwen, geneeskundige dienst en onderwijs) en I $5 \%$ voor kleding. De resterende $\pm 65 \%$ zou de directie in algemeen gangbaar Nederlands geld moeten uitbetalen.

Wel zou de Maatschappij aan zwakke gezinnen een jaarlijkse toelage dienen te geven, die men echter moest verhalen op de instellingen, die deze gezinnen hadden opgezonden. Het ging hier n.l. om aanzienlijke bedragen. Slechts $\mathrm{x} / 3$ der gezinnen kon in eigen onderhoud voorzien. Aan wekelijkse toelagen besteedde de Maatschappij vóór r 859 in totaal $f 20.000$, - per jaar, d.i. $\pm f 45$, - gemiddeld per gezin.

$\mathrm{Na}$ de reorganisatie van I 859 zijn de door Staring, Van Konijnenburg e.a. bepleite wijzigingen in de arbeidsvoorwaarden omstreeks i 865 inderdaad ingevoerd, zodat sindsdien de Maatschappij van Weldadigheid in dit opzicht meer als een normale werkgever is gaan optreden met dien verstande, dat de kolonisten in geval van moeilijke omstandigheden een toelage konden ontvangen.

\section{NIET-AGRARISCHE WERKGELEGENHEID}

In de oorspronkelijke opzet had Van den Bosch het hoofdaccent van de werkverschaffing gelegd bij de ontginning en de landarbeid. In de vorige paragraaf is reeds vermeld, dat hij echter in zijn eerste verhandeling van I 8 r 8 ook rekening hield met de wenselijkheid van lichtere arbeid voor de 
minder sterke mannen, die ook geschikt zou zijn voor de vrouwen. Als zodanig noemde hij het spinnen van vlas en wol tot garen en sajet en het weven van garen tot linnen. Daar er toentertijd een invoeroverschot was van grof linnen, zou deze textielfabricage in de koloniën onschadelijk zijn voor de Nederlandse nijverheid.

Inderdaad was in 1820 in iedere sectie van de koloniën een schuur aanwezig, die als spinlokaal of "spinschool" werd gebruikt. De vrouwen en meisjes moesten hierin een bepaalde hoeveelheid vlas spinnen, terwijl de jongens van 6 tot en met i 5 jaar, die niet op het land werkten, verplicht waren wol te spinnen, dus buiten de schooltijden. De produkten werden door de Maatschappij centraal verkocht; zij betaalde de verrichte arbeid volgens een tariefloonstelsel. Naast de spinschool per sectie had elke kolonie nog de beschikking over een grotere spinzaal. Niettemin was de spinnerij in de eerste jaren vooral bedoeld als een bron van aanvullende werkgelegenheid voor vrouwen en kinderen. De mannen konden bijverdiensten ontvangen door te werken in de turfgraverij, de steenbakkerij en kalkbranderij of door het graven resp. onderhoud van de vaarten in de periode, waarin de landbouw onvoldoende werkgelegenheid bood 24 .

Omdat de latere groepen kolonisten ten dele ongeschikt waren voor de landarbeid, konden deze ook verplicht worden tot z.g. „fabriekmatige arbeid". Degenen, die een ambacht konden uitoefenen, kregen de gelegenheid dit in de koloniën voort te zetten. Wat zij vervaardigden, diende echter uitsluitend ter voorziening van de kolonisten van kledingstukken, schoenen, gereedschappen en huisraad. Deze benodigdheden behoefde de Maatschappij reeds omstreeks I 825 niet meer aan te kopen buiten de koloniën.

In de volgende jaren is de nijverheid steeds meer uitgebreid, al diende men hiermede toen nog alleen de eigen behoeften. In verscheidene hoeven werd een weefgetouw geplaatst. Het is waarschijnlijk, dat de vergroting van de niet-agrarische werkgelegenheid ook noodzakelijk was in verband met de omstandigheid, dat het aantal aanwezige arbeidskrachten groter was dan de gemiddelde arbeidsbehoefte in de landbouw. Om deze reden is ook in juli 1827 ,aan eenige jonge Kolonisten, die de noodige krachten hebben, op hun verlangen de vrijheid verleend, om buiten de Koloniën aan de dijken en wegen in Vriesland te gaan arbeiden"25.

De veranderingen, die in $18{ }_{3} 6$ en volgende jaren in de koloniën werden aangebracht, betekenden o.a. ook, dat het z.g. "fabriekwezen” sterk werd uitgebreid, vooral door de invoering van de katoenweverij. Daar ongeveer een derde deel van alle gezinnen ongeschikt was voor de 
landarbeid, moesten deze overschakelen op het fabriekswerk, eventueel gesteund met een subsidie. In hun hoeven plaatste de Maatschappij drie of vier weefgetouwen van de heer Van den Berghe de Heyder ${ }^{26}$, fabrikant te Leiden. De „fabriekmatige arbeid" bestond in $18{ }_{3} 6$ dus nog vrijwel uitsluitend uit huisnijverheid; men produceerde voor de interne behoeften van de koloniën.

Op grond van de goede resultaten van deze proefneming met de katoenweverij stelde Van den Bosch reeds in 1837 aan de Permanente Commissie voor ook te gaan exporteren. Aldus werd besloten. De generaal vroeg en verkreeg de hulp van enkele relaties uit de zakenwereld. Van Hoboken, handelsmagnaat te Rotterdam, leverde de katoenen garens, terwijl de fabriek van Prévinaire te Haarlem iemand zond om in de koloniën het weven van imitatiekatoen te onderrichten ${ }^{27}$.

Het aantal weefgetouwen was in 1839 toegenomen tot 400 , waarvan I 20 een plaats vonden in een drietal grote schuren, de overige in de hoeven van de "invalide" gezinnen, hoofdzakelijk te Willemsoord. Vanaf dit jaar kan men dus eerst spreken van eigenlijke fabrieksgebouwen in de vrije koloniën naast de katoenweverij als huisnijverheid. In I 840 werd de hoogste produktie bereikt: ruim 800.000 el, waarvan de Maatschappij voor meer $\operatorname{dan} f 220.000$, - aan imitatie- en hemdenkatoen afleverde aan het Departement van Koloniën.

Hoewel volgens het reglement van orde van 1837 , aangehaald door Westendorp Boerma, vooral kinderen van 12 tot I 5 jaar in de katoenindustrie werkten, al naar de tijd van het jaar 6- I 2 uur per dag, kan men toch wel aannemen, dat deze bedrijfstak in eerste instantie als algemene bron van aanvullende werkgelegenheid was bedoeld om het arbeidsoverschot in de koloniën produktief te maken. Als tweede en wellicht belangrijkste doelstelling dient men ongetwijfeld aan te merken de verbetering van de hachelijke financiële omstandigheden, waarin de Maatschappij van Weldadigheid verkeerde. De arbeidslonen waren in de koloniën relatief laag. Het is wel zeker, dat de Maatschappij door de afzet van katoen via het Departement van Koloniën naar Oost-Indië belangrijke inkomsten heeft verworven, dank zij het ministerschap van Van den Bosch aan dit departement.

De vergroting van de niet-agrarische werkgelegenheid in de gewone koloniën had echter tot gevolg, dat de landbouw soms te kampen had met te weinig arbeidskrachten. Het aantal kinderen en jongelui, werkzaam in de katoenweverij, liep in 1838 op tot 400 , waarvan een groot gedeelte vroeger in de landbouw had gewerkt ${ }^{28}$.

In het rapport van de Staatscommissie van $\mathrm{I}_{44 \mathrm{I}}$ is duidelijk uitge- 
sproken, dat de katoenweverij met haar 406 weefgetouwen meer valide arbeiders aan de landbouw onttrok, dan wenselijk was ${ }^{30}$.

Ook Staring en Quarles van Ufford besteedden in 1846 aandacht aan de katoenweverij. Zij bezochten enige kleinere weverijen en ook de grote katoenweverij te Willemsoord. Behalve in deze afzonderlijke gebouwen had men hier en daar in de achterste gedeelten van de hoeven Io of 12 weefgetouwen geplaatst. Per week vervaardigde men in de gewone koloniën ongeveer I000 stuks katoen, voldoende voor de eigen behoefte en de bestellingen. De fabrieksarbeid duurde "slechts ro uren daags", zodat de kinderen van I 2 tot 14 jaar de avondschool konden bezoeken. Het scheen, dat het werk in de fabrieken volstrekt geen nadelige gevolgen voor de gezondheid had, aldus de rapporteurs. Men wisselde dan ook wel af met veldarbeid ${ }^{3} \mathrm{r}$.

Niettemin keurden Staring c.s. het in het algemeen af, dat de Maatschappij aan de „fabriekmatige arbeid" een te grote uitbreiding had gegeven, en wel om twee redenen. In de eerste plaats wegens het feit, dat het Departement van Koloniën volgens het contract naar eigen goeddunken wijziging kon brengen in de bestellingen van katoentjes en deze ook kon beëindigen. Vervolgens omdat vele kolonisten in de katoenweverij slechts één vak leerden, waarin zij t.z.t. buiten de koloniën veelal geen bestaan zouden kunnen vinden. Zowel het risico voor de Maatschappij als voor de jeugdige arbeidskrachten achtten Staring en Quarles van ufford te groot ${ }^{32}$.

Deze bedrijfstak is evenwel na I 846 in stand gebleven. Directeur Van Konijnenburg vermeldde in zijn beschrijving van de vrije koloniën in I 859 , dat er zes grote "fabrijklokalen" stonden met woningen voor vijf fabrieksbazen en onderbazen. De meeste fabriekbazen hadden de leiding over omstreeks roo wevers tegen een inkomen van $f 6,-$ of $f 7,-$ per week met vrije woning en tuin. Enkele fabrieksbazen waren gewone kolonisten, evenals alle onderbazen. In de laatste jaren voor I 859 waren de bestellingen van katoen zeer beperkt en kon de Maatschappij slechts een matig arbeidsloon uitbetalen ${ }^{33}$.

Het was te verwachten, dat men in de eerste jaren na 1859 een voldoende bestelling van katoen zou verkrijgen, echter tegen gewone prijzen. Voorheen had de regering aan de Maatschappij hogere prijzen betaald dan aan de particuliere katoenfabrikanten. Dezen hadden hiertegen voortdurend bezwaar gemaakt, zodat de Maatschappij voortaan met de gewone fabrikanten moest concurreren. Van Konijnenburg meende, dat de Maatschappij hiertoe in staat was en adviseerde derhalve de katoenweverij ook na 1859 voort te zetten, vooral als bron van werkgelegen- 
heid voor kinderen van I $_{3}$ tot 16 jaar, en voor oudere jongelui in de winter. Bovendien zouden de voordelen op de katoenweverij ten goede komen aan de algemene financiële positie van de gereorganiseerde Maatschappij van Weldadigheid.

\section{HET ONDERWIJS}

Het hoofddoel van de stichting van de landbouwkoloniën was de werkverschaffing aan behoeftige gezinnen. Een belangrijke nevenfunctie vond de Maatschappij van Weldadigheid in de opvoeding van de kinderen der kolonisten tot gezonde jonge mensen, gewend aan de veldarbeid, en geschikt voor een werkkring in de gewone maatschappij. Overeenkomstig de gangbare opvattingen van de vooruitstrevende groeperingen in de I gde-eeuwse Nederlandse samenleving heeft de Maatschappij sedert de eerste jaren van de kolonisatie zeer veel belang gehecht aan het onderwijs.

Reeds in I 8 I 8 verklaarde Van den Bosch, dat het onderwijs als "het enige middel moet beschouwd worden om deze klasse van menschen, veelal tot den laagsten trap van verbastering weggezonken, wederom uit hun dierlijken staat op te beuren en te veredelen" 34 .

De kolonistenkinderen uit de eerste koloniën (I en II) bezochten aanvankelijk de school te Vledder, die werd geleid door het hoofd J.H. van Wolda. Te Willemsoord is echter zeer kort na de aanvang van de kolonisatie reeds een eigen Maatschappijschool gebouwd, die in 1820 is geopend. Deze school was een schenking van de Prins van Oranje, later Koning Willem II, naar wien Willemsoord is genoemd. Vervolgens bouwde de Maatschappij op eigen kosten een school te Frederiksoord, één te Wilhelminaoord en enkele bijscholen in de meer verwijderde gedeelten van de koloniën 35 .

In december 1823 werd per dag slechts twee uur lang les gegeven aan drie afzonderlijke groepen leerlingen, t.w. de kleine jongens en meisjes gezamenlijk, de grote meisjes ('s middags) en de grote jongens ('s avonds). De schooltijden waren aangepast aan het seizoen, daar de kinderen buiten schooltijd moesten werken. De bezoeker Von Grouner vermeldde in zijn reisbeschrijving verder, dat het onderwijs vooral was gericht op de ontwikkeling van het verstand. Eén van de onderwijzers, K. Mulder, was drie jaar werkzaam geweest aan de Wehrli-Anstalt van de Zwitserse paedagoog Von Fellenberg te Hofwyl ${ }^{36}$.

Ten aanzien van de aard van het onderwijs is op te merken, dat de Maatschappij in 1820 het advies inwon van de Maatschappij tot Nut van het Algemeen. Waarschijnlijk is de invloed van de eerdergenoemde Van 
Wolda op het onderwijs in de koloniën van het begin af groot geweest. Deze leerling van de Groninger paedagoog Van Swinderen stelde op verzoek van de Maatschappij in januari 1823 een verslag op voor de directeur.

De toen aanwezige drie lagere scholen telden niet minder dan $\mathrm{I} 200$ leerlingen. De oudere jongens moesten ook op zaterdagavonden naar school. Aan elke school was een eerste en een tweede onderwijzer verbonden. Het onderwijs in de koloniën kon volgens Van Wolda de vergelijking met scholen in de omgeving ruimschoots doorstaan. Hij merkte op, dat „de koloniale scholen voor geene anderen in den omtrek behoeven onder te doen" 37 .

Vooral na de aanstelling van Van Wolda tot adjunct-directeur voor het onderwijs (in r 824) is zijn bemoeienis met de scholen in de koloniën toegenomen. Hij oefende deze functie twintig jaren uit, gedurende welke periode hij als volgeling van Pestalozzi zijn stempel drukte op de aard van het onderwijs. Dit werd gericht op een algemene ontwikkeling van de verstandelijke capaciteiten; de zelfwerkzaamheid van de leerlingen was primair, het bijbrengen van feitenkennis kwam op de tweede plaats.

Naast lees-, schrijf- en rekenkunde werden ook de vakken aardrijkskunde en geschiedenis gegeven. Ook praktische vakken als gymnastiek en handenarbeid kwamen voor op het lesrooster. Wijsheid, arbeidzaamheid, zedelijkheid en vaderlandsliefde vormden de doelstelling van het onderwijs. Tevens trachtte men bij de kinderen „eene stille tevredenheid met hunnen eigen stand" te bevorderen.

Uit het voorgaande blijkt, dat het onderwijs in de koloniën qua inhoud en methodiek zeker op een hoger niveau stond dan dat in de gewone plattelandsscholen.

Een dergelijke taak kon de Maatschappij niet uitvoeren zonder leerplicht. Deze is dan ook vanaf de stichting van de koloniën in 1818 van kracht geweest, aanvankelijk vanaf het zesde jaar tot en met de I 2-jarige leeftijd. De oudere kinderen van I 3 en 14 jaar waren verplicht de avondschool te bezoeken. 's Zomers nam de bevolking het met de leerplicht niet zo nauw in verband met de landbouwwerkzaamheden ${ }^{38}$.

In 1830 zijn de officiële schooltijden voor de kinderen van 6 tot $\mathrm{I} 2$ jaar tweemaal zo lang gesteld: in plaats van twee uren per dag moesten zij voortaan van I0.00-12.00 uur en van 14.00-16.00 uur de scholen bezoeken gedurende vijf dagen per week. In de maanden mei, september en oktober hadden de kinderen van Io tot 12 jaar echter vrij om te kunnen helpen bij het poten en rooien van de aardappelen. Ook mocht per gezin één kind in de maanden april tot en met oktober thuis zijn als koehoeder. 
De jongens van $I_{3}$ en $1_{4}$ jaar moesten de avondschool bijwonen van r 8.00-20.00 uur op maandag, woensdag en vrijdag, de meisjes op dinsdag en donderdag 39 .

Het aantal scholen in de gewone koloniën was in $183 \mathrm{r}$ toegenomen tot zes, waarvan één hoofdschool te Frederiksoord, één hoofdschool en twee bijscholen in de langgerekte kolonie Wilhelminaoord en één hoofdschool en één bijschool te Willemsoord. Laatstgenoemde hoofdschool had de meeste leerlingen, n.l. i 7 I op de dagschool en 195 op de avondschool, totaal 366. De kleinste school was de 2 de bijschool te Wilhelminaoord met 22 dag- en 37 avondscholieren. Het totale leerlingental bedroeg in juni $183 \mathrm{I}$ (dag-en avondscholen) $\mathrm{I}$ $72^{40}$.

In de volgende jaren daalde het aantal leerlingen tot 1024 in 1836 . De hoofdscholen in kolonie II en mI telden resp. 300 en 299 leerlingen, de 2 de bijschool in kolonie II werd nog slechts door 39 kinderen bezocht. Neemt men in aanmerking, dat het onderwijzend personeel bestond uit twee leerkrachten per hoofdschool en één leerkracht per bijschool (voor het dag-en avondonderwijs), dan is het duidelijk, dat de onderwijzers een zware dagtaak hadden te vervullen voor in het algemeen grote klassen ${ }^{4}$. Het gemiddelde aantal leerlingen per leerkracht bedroeg op de dagscholen $5 \mathrm{x}$.

Het onderwijs is in $\mathrm{I}$ 84I in alle scholen uitgebreid met enig theoretisch onderricht in de landbouw, ,zoo als die in onvruchtbare streken gedreven en beoefend wordt". De directeur was hiervan een krachtig voorstander. Tevens is het aantal klassen per school vergroot tot drie42.

In het volgende jaar is ook te Groot Wateren „eene kleine landelijke school gebouwd, toereikend om de daar aanwezige kinderen te bevatten"43. Dit schooltje telde slechts I I leerlingen. Het aantal kinderen op de overige zeven scholen (te Willemsoord waren toen twee bijscholen) bedroeg in 1842 niet meer dan 897 . De voortgaande daling werd veroorzaakt door de veroudering van de bevolking. De hoofdschool te Wilhelminaoord was nog steeds de grootste met 235 leerlingen. De twee bijscholen waren hier gevestigd in de Oostvierdeparten en in kolonie vII4.

Staring en Quarles van Ufford waren in 1846 vol lof over „de uitmuntende wijze, waarop in al de Koloniën het schoolonderwijs is ingerigt". Zij vermeldden ook, dat de 2 de bijschool te Willemsoord speciaal was gebouwd voor de kinderen van de Joodse gezinnen, die aldaar in de z.g. Jodenhoek waren gevestigd. Aan deze school was een Joodse onderwijzer verbonden 45 .

Kan men dus aannemen, dat de Maatschappij veel zorg besteedde aan 
het onderwijs en aan de inrichting van de schoolgebouwen, om financiële redenen moest men ook op dit punt wel eens improviseren. Zo kan men in het Algemeen Verslag over I $85^{2}$ lezen, dat de hiervoor genoemde „kleine landelijke school” te Groot Wateren destijds was gevestigd in een zodenhut. Eerst in i 852, dus na io jaren, is hier een nieuw schooltje van steen gebouwd met een pannendak.

Afzonderlijke vermelding verdient het Instituut voor den Landbouw te Wateren, dat de Maatschappij van Weldadigheid in I 823 heeft gesticht. Feitelijk was dit de eerste landbouwschool in de provincie Drenthe en de tweede in Nederland ${ }^{46}$. Het gebouw is terug te vinden in het huidige dorpje Zorgvlied (gemeente Diever), dat destijds nog niet onder die naam bekend was. In $\mathrm{I} 860$ is het Landbouwinstituut gesloten in verband met de verkoop van Wateren en omgeving.

In de 37 jaren van zijn bestaan heeft het Instituut steeds uitsluitend ten doel gehad aan kinderen uit de koloniën van de Maatschappij een opleiding te geven, die hen voorbereidde op een latere functie als ambtenaar in dienst van de Maatschappij. Weliswaar zijn verscheidene pogingen aangewend (o.a. door Jan Kops) aan de landbouwschool te Wateren een meer algemene functie toe te kennen, maar deze gedachten zijn nooit gerealiseerd 47 .

Het voortgezet onderwijs aan deze instelling was zowel theoretisch als praktisch van aard met het accent duidelijk op de praktische werkzaamheden. Hiervoor was rondom het Instituut \pm 85 ha heide beschikbaar, die allengs werd ontgonnen. Tevens was aan het Instituut een boerderij verbonden.

In de geschiedenis van het onderwijs te Wateren zijn drie perioden te onderscheiden. De eerste strekt zich uit van de oprichting tot I 83I. In deze jaren berustte de leiding bij $\mathrm{K}$. Mulder, de eerdergenoemde oudleerling van het instituut van Fellenberg (Zwitserland), een geestverwant van Pestalozzi. Het onderwijs moet naar toenmalige maatstaven modern ( verlicht”) zijn geweest, hetgeen strookte met het voornemen van Wateren een modelschool te maken.

In I $_{3}$ I werd de eerste directeur overgeplaatst en opgevolgd door Van Wolda, de adjunct-directeur voor het onderwijs in alle koloniën. In de volgende jaren werd de oppervlakte cultuurgrond bij het Instituut aanzienlijk uitgebreid en stichtte men een veefokkerij, die ten dienste stond van de overige koloniën van de Maatschappij. Als gevolg van het een en ander kwam het theoretische onderwijs in het gedrang. Het werd beperkt tot enig avondonderwijs in elementaire vakken, die met de landbouw weinig hadden uit te staan. Deze situatie duurde voort tot $\pm 185 \mathrm{I}$. 
De laatste periode (1 $851-1860)$ kenmerkte zich door meer afwisselend praktisch onderwijs overdag en op een hoger niveau staande avondlessen. Op 20-jarige leeftijd konden de leerlingen nog één of twee jaren als boerenknecht werkzaam zijn op de grote boerderijen te Veenhuizen, die behoorden bij de wezengestichten en het bedelaarsgesticht.

Het aantal „kwekelingen" steeg van 30 in de eerste maanden van 1824 tot 60 in 1826 . In volgende jaren schommelde het leerlingental om de 75 .

Dat het Instituut te Wateren niet beantwoordde aan de gestelde doeleinden, blijkt uit de door de oud-leerlingen uitgeoefende beroepen. Fabius vermeldde, dat in de periode $183 \mathrm{I}$ tot en met $184^{\circ}$ van de 145 ontslagen jongens slechts $\mathrm{r} 8$ een betrekking in de koloniën waren gaan vervullen. Het aantal vacante plaatsen bij het bestuur van de koloniën is in deze tien jaren ongetwijfeld groter geweest. Verreweg de meeste oud-leerlingen van het Instituut vertrokken naar de "gewone maatschappij". 36 jongens werden boerenknecht, 25 gingen in de steden werken en 2 bij de binnenscheepvaart, terwijl niet minder dan 59 jongens beroepsmilitair werden (w.v. I officier, 6 onderofficier, 14 korporaal, I schermmeester en 35 fuselier). Slechts ongeveer $\mathrm{r} / 3$ van de kwekelingen vond een werkkring in de landbouw, zodat het Instituut ook in dit opzicht van beperkte betekenis was48.

Niettemin pleitte directeur Van Konijnenburg in april 1859 in zijn brochure voor het behoud van het Instituut voor den Landbouw49. $\mathrm{Na}$ hun opleiding kregen de meeste leerlingen volgens hem een gunstige plaatsing; hij noemde nog betrekkingen bij het onderwijs en als huisbediende. Van Konijnenburg ontving vele verzoeken om toelating tot het Instituut. Als bijlage gaf hij bij zijn brochure een antal uittreksels uit brieven van oudleerlingen, die gedurende zes jaren te Wateren waren opgeleid.

Ondanks deze poging het Instituut te doen voortbestaan, besloot de Maatschappij tot verkoop van Wateren en omgeving. In $1860 \mathrm{kwam}$ het einde van het Instituut voor den Landbouw, de enige school voor voortgezet onderwijs in de koloniën van de Maatschappij van Weldadigheid in de periode tot 1859 . 


\section{SA MENVATTING EN CONCLUSIES; \\ OVERZICHT VAN DE ONTWIKKELING NA 1859}

Ir laatste hoofdstuk heeft een tweeslachtig karakter. Het ligt voor de hand op deze plaats een globale samenvatting te geven van hetgeen in de voorafgaande hoofdstukken als meest kenmerkende aspekten van de landbouw in de vrije koloniën der Maatschappij van Weldadigheid naar voren is gekomen. Deze samenvatting kan tevens een bondig antwoord zijn op de vragen, die aan het einde van hoofdstuk I de probleemstelling vormden. Vervolgens zullen enige conclusies worden geformuleerd.

Een dergelijke opzet bevredigt echter niet geheel en al. $\mathrm{Na}$ kennisneming van de ontwikkeling van de landbouw van 18 I 8 tot 1859 is men onwillekeurig geneigd de vraag op te werpen, welke richting de koloniën na de reorganisatie van i 859 zijn ingeslagen. Volledigheidshalve zal daarom aan het einde van dit hoofdstuk een beknopt overzicht worden geschetst van de landbouwkundige geschiedenis van i 859 tot heden.

\section{VERWERVING VAN GROND EN ONTGINNING}

Hoewel in Drenthe omstreeks 1818 zeer veel woeste grond voorhanden was (ruim $2 / 3$ van de provincie bestond uit heidevelden en veengrond), vormde de aard van het eigendomsrecht een grote belemmering voor de aankoop door derden. De gemeenschappelijke eigendom van de woeste gronden was in handen van de boermarken. Teneinde langdurige en mogelijk vruchteloze onderhandelingen met de volmachten van de marken te voorkomen koos de Maatschappij van Weldadigheid een meer efficiënte tactiek ter verkrijging van de benodigde grond.

In de eerste plaats zocht men een particuliere eigenaar van een landgoed, die bereid was tot verkoop van zijn bezittingen. Deze eigenaar vond de Maatschappij in R.A.L. Nobel, lid van Provinciale Staten van Drenthe, die zijn landgoed Westerbeeksloot in de gemeente Vledder in de zomer van 1818 verkocht voor $f 56.000$,- - De Maatschappij werd hierdoor eigenaar van een landhuis, een herberg, drie boerenplaatsen, 
drie keuterboerderijtjes en een hoeveelheid los grasland, bouwland, bos en heidegrond. Van de totale oppervlakte van $53^{2}$ ha was 62 ha in cultuur als bouw- of grasland, 53 ha bestond uit bos, terwijl 417 ha nog als woeste heidegrond aanwezig was. Door deze transactie kon men de eerste kolonistengezinnen direct in de landbouw tewerkstellen en overigens ook bij de verdere ontginning. Op deze gronden ontstonden de koloniën I en II (Frederiksoord) en een gedeelte van IV (Wilhelminaoord).

De volgende fase van het aankoopbeleid had vermeerdering van de voorraad woeste grond ten doel. In een snel tempo sloot de Maatschappij in de jaren 18 I 9-1 824 nog 75 koop- en ruilovereenkomsten. Slechts 20 van de objecten bestonden uit volledige boerderijen met opstallen. Hierbij ging het niet zo zeer om deze hofsteden zelf als wel om de in de koop begrepen aandelen in onverdeelde marken (heide- en veengrond). Dit blijkt uit het feit, dat de Maatschappij in vele gevallen de landbouwbedrijven naderhand doorverkocht, maar de aandelen zelf behield. Van de overige aankopen hadden 20 betrekking op losse percelen bouw- en grasland, heide en veengrond. De resterende 35 overeenkomsten betroffen de aankoop van losse aandelen in de boermarken. Op deze wijze namen de rechten van de Maatschappij toe in de onverdeelde heide in de gemeenten Vledder, Diever, Ooststellingwerf en Weststellingwerf. Door het afsluiten van convenanten met de marken verkreeg men vervolgens uitgestrekte heidevelden ter grootte van ruim 4000 ha in eigendom.

Alleen met de gecommitteerden van de erfgenamen van het kerspel Steenwijkerwold kon de Maatschappij in I 820 een rechtstreekse koopovereenkomst sluiten, die ongeveer 298 ha heideveld opleverde voor de stichting van kolonie III (Willemsoord).

De derde fase, bestaande uit het afsluiten van convenanten met de marken, had betrekking op de Marke van Vledder, de Marke van Doldersum, de Marke van Diever en Wateren en de Marke van Appelscha. De uitscheiding van de Maatschappij uit deze marken had resp. plaats in 1820, I 821,1823 en 1824 . De onder Doldersum verkregen heidegrond is voor een klein gedeelte gebruikt voor de aanleg van kolonie vII, die echter nooit is voltooid. Op de heide te Wateren richtte men in 1823 het Instituut voor den Landbouw op, dat bestemd was voor de opleiding van lagere en middelbare ambtenaren voor de Maatschappij. Deze instelling was tevens de eerste landbouwschool in Drenthe en één van de eerste van Nederland. De in de omgeving van Appelscha verworven woeste grond is niet meer voor kolonisatie benut.

Bij de kadastrale opneming van de goederen omstreeks 1830 bleek de 
Maatschappij eigenaar te zijn van ruim 4100 ha grond in de gemeenten Vledder, Diever en omgeving. Hieronder bevond zich bijna 1400 ha cultuurgrond en $5^{\circ}$ ha bos; niet minder dan ruim $265^{\circ}$ ha was woest in de vorm van heide, veen en zandverstuiving.

Als eerste handeling bij de ontginning van heide met maximaal i $5 \mathrm{~cm}$ veen ging men de grond afplaggen tot $\pm 4 \mathrm{~cm}$ diepte. De plaggen werden verbrand en de ondergrond met de hak doorgespit tot hoogstens $45 \mathrm{~cm}$ onder het maaiveld. De nog warme plaggenas werd als meststof over het land gebracht, soms aangevuld met natte turf. In de herfst bemestte men met een mengsel van verse paardenmest, straatvuil, ongebluste kalk en plaggen om vervolgens in het voorjaar zomerrogge te zaaien als eerste gewas.

Bij de hoogveenontginning stak men de bovenlaag tot $\pm 30 \mathrm{~cm}$ af om te verbranden. Indien de veendikte meer dan $90 \mathrm{~cm}$ bedroeg, ging men turf steken. Was de veenlaag minder dik, dan werd deze bezand met omstreeks $15 \mathrm{~cm}$ zand uit de sloten en vermengd met as en het hiervoor genoemde mengsel van paardenmest.

De Maatschappij was van mening, dat de toegepaste ontginningsmethoden naar hun aard nieuw waren. In het bijzonder achtte men de diepe grondbewerking en de vermenging van veen met zand van veel belang.

Bebossing van heidegrond is tot 1859 slechts weinig uitgevoerd. In 1832 is ten noorden van het Sterrebosch te Frederiksoord een heideperceel van 6 ha bezaaid met gewone grove den.

Overigens is sinds 1825 in het algemeen slechts weinig grond in cultuur gebracht. Vermelding verdient de ontginning van een perceel heide van $3^{\circ}-40$ ha tot blijvend grasland bij Wateren in $1832 / 33$. In deze omgeving zijn ook enkele percelen bebost met dennen, eiken en berken.

\section{PRODUKTIE - OMSTANDIGHEDEN}

De ruimtelijke ligging van de vrije koloniën vertoonde een eigenaardige T-vorm, die veroorzaakt werd door de min of meer toevallige situering van de verkregen heidegrond. Langs de grenzen van Friesland, Overijssel en Drenthe lagen de koloniën Willemsoord, Wilhelminaoord en kolonie vII (het latere Boschoord) met een grootste lengte van 3 uren gaans. Loodrecht hierop strekten zich in de gemeente Vledder een deel van Wilhelminaoord en de kolonie Frederiksoord uit. Het instituut te Wateren lag geheel afgezonderd in de noordwestelijke hoek van de gemeente Diever, hoewel het door de heide van Doldersum verbonden was 
met kolonie vir. De vrije koloniën en de heidevelden vormden een aaneengesloten complex.

Door de grote afstanden werd het bestuur bemoeilijkt. De directie te Frederiksoord oefende het beheer uit via de adjunct-directeur van de vrije koloniën en de onderdirecteuren, die aan het hoofd van de afzonderlijke koloniën waren gesteld. Elke kolonie was weer opgebouwd uit twee of meer wijken, elke wijk uit twee secties van 12 woningen. De onderdirecteuren, wijk- en sectiemeesters woonden in het gedeelte van de koloniën, waarover zij het toezicht uitoefenden. Bij de herindeling van I 826 zijn de oorspronkelijke zes koloniën samengevoegd tot drie, n.1. Frederiksoord, Wilhelminaoord en Willemsoord.

In verband met de uiteenlopende hoogteligging van het gebied zou een goede waterbeheersing van veel betekenis zijn geweest. In het algemeen was echter alleen sprake van maatregelen in het belang van de afwatering.

De detailontwatering had plaats door de grenssloten van de kolonistenhoeven en hier en daar door begreppeling. Omstreeks i 820 liet de Maatschappij langs de lengte-assen van het kolonisatiegebied twee kanalen graven, die zowel voor de scheepvaart als voor de hoofdafwatering dienst deden. De Kolonievaart verbond de Vledder Aa via Frederiksen Wilhelminaoord met Noordwolde en de Linde in Friesland. Loodrecht hierop groef men langs de Drents-Friese grens zijkanalen naar Willemsoord en Boschoord.

Waterinlaat was alleen mogelijk bij de Vledder Aa door middel van een windmolen. De waterstand van de Aa was evenwel vaak te laag om de kanalen in bevaarbare staat te kunnen houden.

Langs de doorgaans rechte hoofd- en zijwegen werden bij de ontginning de kolonistenhoeven geprojecteerd. Elke hoeve bestond uit één rechthoekige kavel ter grootte van gemiddeld 2,4 ha in de oudste koloniën te Frederiksoord en 2,7 of 2,9 ha in Willemsoord en Wilhelminaoord.

Op grond van het voorgeschreven bouwplan was elke hoeve in de eerste jaren van de kolonisatie verdeeld in 7 percelen. Naderhand is het aantal percelen per hoeve sterk vergroot in verband met het zeer ingewikkelde vruchtwisselstelsel. Omstreeks I 859 trof men per hoeve 20 - 50 perceeltjes aan, die elk een afzonderlijk gewas droegen en door brede greppels waren gescheiden. De gemiddelde perceelsoppervlakte varieerde van 0,05 tot $0, \mathrm{I}$ ha.

Beschouwt men de kolonistenhoeven als afzonderlijke bedrijfjes, dan bedroeg de bedrijfsgrootte dus doorgaans iets minder dan 3 ha of 3,5 morgen (mg). Volgens het eerste plan van Van den Bosch zou een gezin 
van zes personen voor zijn bestaan voldoende hebben aan de opbrengst van I mg aardappelen, te verbouwen door uitsluitend handenarbeid. In afwisseling met een braakjaar was per gezin $2 \mathrm{mg}$ nodig. Bovendien zou men voor elk gezin I mg met sparren beplanten, waarvan de opbrengst later ten goede kon komen aan de kinderen voor hun uitzet. Met enige roeden tuingrond voor eigen gebruik zou een hoeve derhalve $\pm 2,6$ ha (3 $\mathrm{mg}$ ) groot moeten zijn.

In de praktijk zijn de braakjaren en de bosbouw op de hoeven niet ingevoerd. Van de omstreeks 3 ha cultuurgrond is aanvankelijk 28 are bestemd tot tuingrond. Van den Bosch heeft weliswaar de mogelijkheid overwogen per gezin meer grond uit te geven, maar hij is hiertoe niet overgegaan om drie redenen. Allereerst wilde hij door de kolonisatie een zo groot mogelijk aantal arme gezinnen een redelijk bestaan bieden. In de tweede plaats dienden de kolonisten het niet al te goed te hebben in verband met de kans op verkwisting. Tenslotte moest de Maatschappij rekening houden met de beschikbare arbeidskracht van de kolonisten, die voor het merendeel in lichamelijk en geestelijk opzicht niet sterk waren, "dikwijls het uitschot van de stadsbevolking”.

Omstreeks I 827 ontstond het inzicht, dat elk gezin de beschikking moest hebben over $6 \mathrm{mg}$ (ruim 5 ha) cultuurgrond, opdat de koloniën geheel in de behoeften van de bewoners zouden kunnen voorzien. Vergroting van de bedrijven heeft echter tot 1859 niet plaatsgehad.

Het landbouwbedrijf, dat de Maatschappij van Weldadigheid bij het Instituut voor den Landbouw te Wateren in eigen exploitatie had, was in 1826 omstreeks $5^{\circ}$ ha groot. Door verdere ontginning en samenvoeging met andere boerderijen is dit bedrijf uitgegroeid tot ongeveer $200 \mathrm{ha}$ cultuurgrond.

In de vrije koloniën zijn de kolonistengezinnen gehuisvest in afzonderlijke boerderijtjes van een uniform type, die op vaste afstanden langs de wegen zijn gebouwd. Het bedrijfsgedeelte was opgetrokken van houten palen met muren van geteerde planken en was bij het oudste model breder dan het woongedeelte. Achter elke hoeve bevond zich een gierbak, waarmee de mestgang van de koestal en het sekreet in verbinding stonden. De nieuwere hoeven hadden een verbreed woonhuis. Het woongedeelte was gebouwd van muren zonder spouw. Ook overigens heeft de Maatschappij een lichte constructie toegepast, terwijl zij later onvoldoende onderhoud uitvoerde. 
In tegenstelling tot de normale gemengde bedrijven van de Drentse zandgrond had de Maatschappij van Weldadigheid in de vrije koloniën slechts de beschikking over enkele ha natuurlijk grasland. Vanwege de mestbehoefte, die op de uitgestrekte oppervlakte ontginningsgrond relatief groot was, was de Maatschappij genoodzaakt deze grond niet uitsluitend voor akkerbouwgewassen te bestemmen. Van den Bosch voerde daarom een intensief wisselbouwsysteem in zonder blijvend grasland en legde tevens sterk de nadruk op een goede mestbereiding.

Hoewel Van den Bosch zijn landbouwkundige kennis grotendeels had geput uit de publikaties van schrijvers als Thaer, Sinclair, Serrurier en Kops, en geen praktische ervaring had, ging hij in het bestuur van de Maatschappij door voor de enige "landbouwkundige”, wiens adviezen men dan ook blindelings opvolgde. Zo kon hij zijn inzichten betreffende het systeem van de "verlichte landbouw" in de koloniën in praktijk brengen.

Feitelijk vormde de mestbehoefte het grote knelpunt van de landbouw. Om hierin te kunnen voorzien pleitte Van den Bosch in de aanvang reeds voor de cultuur van brem als tweejarig groenbemestingsgewas, een surrogaat voor de stalmest. Wegens gebrek aan goed zaaizaad is deze teelt niet direct ingevoerd.

Exclusief de tuingrond werden per hoeve twee percelen bestemd voor aardappelen en rogge en drie percelen voor groenvoederverbouw, waaronder tijdelijk klaver- en grasland met het nieuwe fioringras. In de verhouding bouwland-grasland $=8$ : I I resulteerde dit stelsel in een "gemengd" bedrijfstype, wanneer men de voedergewassen tot het grasland rekent. In het graan werd klaver als ondervrucht en nagewas ingezaaid.

In 1828 ontwierp Van den Bosch een nieuw reglement voor de landbouw, waarin een belangrijke plaats was ingeruimd voor de bremcultuur. Eind i 829 besloeg de brem dan ook $20 \%$ van de cultuurgrond, terwijl de verhouding tussen akkerbouw- en groenvoedergewassen was gewijzigd in $3: \mathrm{r}$. De teelt van voedergewassen had men dus anzienlijk ingekrompen. Tegelijkertijd werd de stalvoedering ingevoerd in het belang van de mestverzameling. Door deze hervormingen hoopte Van den Bosch de koloniën in staat te stellen zelf in alle behoeften te voorzien. Niets bleek minder waar; jaarlijks waren grote bedragen nodig voor de aankoop van hooi en stalmest.

De toenmalige directeur Van Konijnenburg kon zich met de opvat- 
tingen van Van den Bosch niet verenigen. Eerstgenoemde was aanvankelijk tegen de bremteelt en voorstander van een verdubbeling van de rundveestapel tot ruim 900 stuks met vergroting van het areaal voedergewassen. In een brief aan het bestuur van de Maatschappij wees hij in 1831 nog op het vele onkruid en de gebrekkige grondbewerking als symptomen van "de achterlijkheid van den kolonialen landbouw".

Tijdens het verblijf van generaal Van den Bosch in Oost-Indië zag Van Konijnenburg zijn kans schoon en breidde hij op eigen gezag de veehouderij uit. Hij bracht de bremteelt terug tot $15 \%$ van de cultuurgrond en voerde het areaal kunstweide op tot een verhouding akkerbouw : groenvoeder $=\mathrm{I}, \mathrm{I}: \mathrm{I}$.

Als tegenmaatregel en wegens de nog steeds onvoldoende resultaten van de landbouw ontwierp Van den Bosch na zijn terugkeer tenslotte in I 836 wederom een hervormingsplan, dat in hetzelfde jaar van kracht werd. Het was een laatste poging de koloniën zelfverzorgend te maken zonder regeringssteun door de brembemesting te stimuleren en de veestapel in te krimpen. Voortaan nam de brem een belangrijke plaats in op niet minder dan 30\% van de cultuurgrond. De groenvoederteelt werd daarentegen sterk verminderd, zodat bovengenoemde verhouding $6:$ I was.

Hoewel van verscheidene kanten is aangedrongen op uitbreiding van de rundveestapel en de oppervlakte voedergewassen, heeft het bestuur van de Maatschappij aan deze aanbevelingen geen gevolg gegeven. De Permanente Commissie nam het standpunt in, dat de maximale omvang van de veestapel werd bepaald door de zuivelbehoefte, terwijl de behoefte aan rogge en aardappelen het areaal voedergewassen beperkte. Zo is tot I 859 weinig in het landbouwstelsel veranderd.

Van den Bosch is steeds overtuigd geweest van het belang van de mestvoorziening voor de landbouw in zijn koloniën. Aan de eerste kolonisten werden twee koeien per gezin in bruikleen verstrekt. Ook de fecaliën werden angstvallig goed verzameld in de mestputten achter de woningen, evenals het keukenafval en het waswater. Door groenbemesting en het houden van schaapskudden werd de mestproduktie aangevuld. Als de kolonisten de strenge voorschriften voor de mestbereiding goed toepasten, zou de eigen mestvoorziening volgens de berekening van Van den Bosch zijn verzekerd. Zelfs voerde de Maatschappij chemisch mestonderzoek uit om te bepalen, of de mest voldoende was verteerd en hoeveel kalk men moest toevoegen.

De eerste proeven met brembemesting zijn in $1826 / 27$ te Wateren genomen. Zij betroffen de teelt van rogge en aardappelen na onderge- 
spitte brem. In latere jaren verbouwde men de aardappelen vrijwel uitsluitend op bremland, doorgaans aangevuld met een halve gewone bemesting, soms ook met een hele normale bemesting. $\mathrm{Na}$ tien jaar bremcultuur liepen de meningen nog steeds uiteen over het nut van deze groenbemester, hoewel de aardappelopbrengst na brembemesting af en toe 10 tot $20 \%$ groter was dan na gewone bemesting.

Men kan dan ook stellen, dat in 1836 het voordeel van de bremcultuur onvoldoende was gebleken, toen Van den Bosch de bremteelt op grote schaal ging invoeren. Het feit echter, dat in de gewone koloniën de gebruikte mest in sommige jaren zelfs voor meer dan de helft uit aangekochte mest bestond, dreef hem tot het aangrijpen van dit redmiddel.

De noodzaak tot mestaankopen bleef evenwel aanwezig. Zo bestond in 1843 de gebruikte mesthoeveelheid weliswaar voor $30 \%$ uit brembemesting, maar toch had men voor $16 \%$ mest moeten kopen, hetgeen ruim $f 7700$, - vergde. Ook bleek, dat de bremcultuur aan het onkruid de gelegenheid verschafte welig te tieren.

De Maatschappij besloot ook andere mestbronnen aan te boren. In I 844 zijn de eerste proeven met guano genomen, die onvoldoende resultaat opleverden in vergelijking tot koemest.

Sinds omstreeks $185^{\circ}$ werden de juichkreten over het uitmuntende nut van de bremteelt schaarser en de mestaankopen groter van omvang, b.v. $f 9300,-$ in $1855, f_{16} 6000,-$ in 1856 en $f 12.400,-$ in 1857 . Het wondermiddel van de brem had niet het gewenste resultaat gehad.

De vruchtwisseling was in I 820 een variant op het Norfolkse systeem, nl. gerst met klaver als ondervrucht, klaver, rogge met knollen als nagewas en in het vierde jaar aardappelen. Deze vruchtopvolging had dus plaats op vier percelen per hoeve. In 1822 was het systeem reeds uitgebreid tot acht slagen. De gerst was vervangen door zomerrogge, terwijl de klaver gedurende twee jaar op het land bleef. In het vijfde jaar werden vlas en groenvoeders ingevoegd. Het gehele teeltplan bestond uit $50 \%$ rogge, $30 \%$ voedergewassen, $15 \%$ aardappelen en $5 \%$ vlas. Ook nam men al gauw proeven met winterraapzaad, wintertarwe, zomerraapzaad, mangelwortelen en erwten. In I 827 deden ook de Zweedse rapen, koolrapen of Ruta-baga hun intrede als voedergewas.

Vooral na ${ }_{1} 836$ deed de ingevoerde bremcultuur zijn invloed gelden op de vruchtwisseling. Ofschoon deze in beginsel eenvoudig van opzet was, nl. achtereenvolgens rogge met brem als nagewas, brem en aardappelen, was de praktijk ingewikkelder. Een deel van de brem werd door klaver vervangen (tweejarig), terwijl in het derde jaar in plaats van een gedeelte van de aardappelen ook vlas werd verbouwd. Het teeltplan 
resulteerde in $33 \%$ rogge, $26 \%$ brem, $19 \%$ aardappelen, $14 \%$ klaver en $7 \%$ vlas.

Nadat nog enkele wijzigingen in de vruchtopvolging waren aangebracht. concludeerde Staring in I $84^{6}$, dat het voorgeschreven schema resulteerde in niet minder dan 18 slagen, hetgeen hij een onmogelijk systeem noemde, dat in de praktijk niet was toe te passen. Ondanks deze en andere kritiek bracht het bestuur van de Maatschappij tot 1859 geen vereenvoudiging aan in de vruchtwisseling.

De belangrijkste akkerbouwgewassen waren rogge en aardappelen. In het algemeen lag de opbrengst van de rogge per ha in de gewone koloniën op ongeveer $60 \%$ van de elders in Drenthe en Overijssel gemiddeld behaalde oogsten. In de koloniën oogstte men slechts het viertot vijfvoudige van het zaaizaad tegenover het achtvoudige buiten de koloniën. Te Wateren was de rogge-opbrengst echter wel $50 \%$ hoger dan in de gewone koloniën.

De aardappelen deden het na 1840 in Wateren minder goed dan in Frederiksoord c.a. In de gewone koloniën nam de gemiddelde aardappelopbrengst per ha van i 83 I tot i 845 langzaam toe, hoewel een normale oogst van $230 \mathrm{mud} / \mathrm{ha}$ alleen in $\mathrm{r} 843 \mathrm{en} \mathrm{I} 844$ werd bereikt. Dit was het acht- tot negenvoudige van de hoeveelheid pootgoed. Het kwam dan ook maar zelden voor, dat de behoefte van de kolonisten door de rogge- en aardappeloogst werd overtroffen.

Vooral door het optreden van de gevreesde aardappelziekte in r 845 en volgende jaren is de aardappelopbrengst aanzienlijk teruggelopen tot de helft à tweederde van de oogst in de voorafgaande jaren. Ook voor de koloniën betekende de aardappelziekte niet minder dan een ramp. Bovendien veroorzaakte de roest ter zelfder tijd een aantal geringe roggeoogsten. Verschillende malen sprong de regering bij met financiële hulp in verband met de misoogsten. De enige remedie tegen de aardappelziekte zag men in het vroeg poten.

Ten aanzien van de veestapel verdient vermelding, dat de Maatschappij zich in 1820 voorstelde aan elk gezin twee koeien te verstrekken tegen $f \circ$, ro vergoeding per week per koe voor het gebruik van de melk. In verband met de noodzakelijke kostbare hooiaankopen is dit aantal reeds in 1822 verminderd tot eén koe per gezin. Toch had men in 1827 nog gemiddeld $\mathrm{r}, 4$ melkkoeien per gezin, sinds $\mathrm{r} 84^{\circ}$ echter $\pm 0,9$.

Was de melkveedichtheid per 100 ha grasland (incl. kunstweide) in I 827 nog 70 koeien, door de sterke inkrimping van de oppervlakte voedergewassen bedroeg dit dichtheidsgetal in $184^{\circ}$ niet minder dan $35^{\mathrm{I}}$. 
Hieruit blijkt wel duidelijk de noodzaak van omvangrijke aankopen van hooi buiten de koloniën.

Een gevolg van de schrale voeding van het vee was zeker ook de relatief geringe produktie van boter, die de directeur in de gewone koloniën in $\mathrm{I}_{32} \mathrm{~b}$ b.v. schatte op $5^{\circ} \mathrm{kg}$ per koe, d.i. de helft van de destijds elders verkregen opbrengst van goed gevoerde koeien. De stalvoedering is blijkbaar niet geheel ingevoerd. In de gewone koloniën paste men in 1838 de z.g. halve stalvoedering toe: 's zomers stonden de koeien alleen 's nachts op stal, overdag werden zij geweid.

Voor de Maatschappij is het verlies in de veehouderijsector in de gewone koloniën steeds aanzienlijk geweest. Het is voor de jaren vóór I 859 geschat op $f 20.000$,- - per jaar.

\section{ARBEIDSVERHOUDINGEN}

De oorspronkelijke plannen van Van den Bosch hielden in, dat elke kolonist na enkele jaren als pachter voor eigen rekening zijn hoeve zou beheren. Hij moest dan een lage pachtsom betalen en een uniforme bedrijfsvoering toepassen. Ook zou Van den Bosch het voornemen hebben gehad de hoeven na een reeks van jaren aan de kolonisten in eigendom over te dragen.

Eigendomsoverdracht heeft echter in het geheel niet plaatsgehad, terwijl verpachting slechts in weinige gevallen is voorgekomen. In de praktijk begonnen alle kolonisten als arbeiders in dienst van de Maatschappij van Weldadigheid. Zij bewerkten de grond in gezamenlijke arbeid onder leiding van de sectiemeesters voor rekening van de Maatschappij, die een tariefloon uitbetaalde.

De meest oppassende en vlijtigste kolonisten-arbeiders konden via een onderscheidingensysteem met koperen, zilveren en gouden medailles opklimmen tot z.g. vrijboeren. $\mathrm{Zij}$ waren in feite pachters, die het vrije gebruik van hun hoeven hadden en de vrije beschikking over hun oogst. Ook de arbeiders moesten verschillende betalingen aan de Maatschappij verrichten, t.w. voor schuldaflossing, administratiekosten, onderwijs en het ziekenfonds. Elke kolonist had één koe in bruikleen, maar de kalveren waren zijn eigendom, evenals de aardappelen en groenten van de tuinpercelen.

De verplichte betalingen, te voldoen in natura of door inhouding op het arbeidsloon, waren voor vele kolonisten in verhouding tot de oogst zo hoog, dat slechts weinige arbeiders in staat waren vrijboer te worden. In 1848 hadden van ongeveer 430 kolonisten niet meer dan 25 de status 
van vrijboer. Zij konden toestemming krijgen buiten de koloniën te gaan werken. Als vrijboeren bleven zij verplicht de algemene voorschriften voor de koloniale landbouw ook op hun bedrijven toe te passen en het overschot van hun produkten aan de Maatschappij te verkopen. Zij genoten dus een zeer beperkte vrijheid.

Het tariefloon is reeds in 1822 vervangen door een stelsel van minimum- en maximumlonen, dat tot $\mathrm{r} 859$ is gehandhaafd. Wat na aftrek van de inhoudingen van het arbeidsloon overbleef, kregen de kolonistenarbeiders uitbetaald als winkelgeld in z.g. koloniale munt, die zij alleen in de koloniewinkels konden besteden. Uit vergelijkingen is af te leiden, dat het loonpeil in de koloniën 's winters hoger, 's zomers lager was dan buiten de koloniën.

\section{CONCLUSIES}

Bij de formulering van de conclusies, die uit deze studie voortvloeien, is het gewenst zich rekenschap te geven van enkele factoren, die niet van belang zijn ontbloot. Vooropgesteld zij, dat met name de landbouwkundige aspecten van de kolonisatie te Frederiksoord en omgeving onderwerp van beschouwing zijn geweest. Ook wanneer men deze beperking aanbrengt, blijft de moeilijkheid, dat een beoordeling van een activiteit, die plaatsgreep in de periode van $1818-1859$, dient te worden gezien in het licht van de toenmalige omstandigheden. Het is zeker onjuist bij het achteraf trekken van conclusies deze tijdsfactor uit het oog te verliezen. Tenslotte wordt in herinnering gebracht, dat de weinige landbouwbedrijven, die in het verleden een boekhouding voerden, stellig niet representatief waren voor de bedrijfstak landbouw als geheel of een bepaald gebied. Dit geldt met name voor een instelling als de Maatschappij van Weldadigheid.

Uit de doeleinden van de kolonisatie komt direct de conclusie naar voren, dat de landbouwkoloniën niet zijn gesticht als een project van een naar financiële winst strevende onderneming, maar als een toevluchtsoord voor sociaal-economisch zwakke gezinnen. Het is duidelijk, dat een dergelijke opzet en doelstelling in het algemeen een in economische zin niet rendabele investering vraagt. Hier staat dan tegenover, dat een sociale winst wordt behaald, die echter niet in een geldbedrag is uit te drukken. In het geval van de landbouwkoloniën was de Maatschappij van Weldadigheid wel in steeds toenemende mate genoodzaakt te trachten het financiële verlies zo gering mogelijk te doen zijn in verband met de afwezigheid van een duidelijk en blijvend subsidiebeleid van de zijde van 
de overheid. Deze noodzaak hield derhalve toch de wenselijkheid in van een zo economisch mogelijk beheer van de koloniën, ook ten aanzien van de landbouw.

Reeds in de eerste jaren van de kolonisatie heeft de Maatschappij niet de nodige zuinigheid betracht bij het aankoopbeleid. Van een proefkolonisatie is feitelijk geen sprake geweest. Terwijl men in het geheel geen zekerheid kon hebben ten aanzien van het welslagen van de onderneming, zette de Maatschappij niet alleen de kolonisatie in betrekkelijk snel tempo voort, maar tevens werden woeste gronden in te grote uitgestrektheid in een te korte tijd aangekocht. Zelfs nadat de vestiging van kolonisten in 1823 tot stilstand kwam, werd het bezit van woeste grond nog aanzienlijk uitgebreid. Het gevolg van dit onevenwichtige beleid was, dat in 1859 nog geen $40 \%$ van de grond in het gebied van de vrije koloniën in cultuur was. De investering in 2500 ha woeste grond heeft gedurende tientallen jaren geen rente opgebracht. Dit renteverlies is evenmin gecompenseerd bij de latere verkoop in $\mathrm{s} 860$, toen een voor de landbouw minder gunstige tijd was aangebroken.

Ondanks de gunstige opvattingen, die de Maatschappij destijds huldigde over de toegepaste ontginningsmethoden, is naderhand wel gebleken, dat hieraan enkele tekortkomingen kleefden. De heidegrond is onvoldoende diep doorgespit, zodat harde lagen in de ondergrond niet werden gebroken. Dit gaf aanleiding tot wateroverlast. Het staat verder wel vast, dat de kleinere oppervlakten hoogveen na de afgraving te weinig zijn bezand. In het algemeen is vrijwel geen egalisatie uitgevoerd. Een gedeelte van de cultuurgrond van de Maatschappij heeft ook thans nog behoefte aan herontginning.

De geografische ligging van de langgerekte koloniën en het Instituut te Wateren vormde een belemmering voor een efficiënt beheer en toezicht. Bovendien had de Maatschappij van Weldadigheid alleen voor de gewone koloniën en Wateren te maken met drie provinciale besturen en vier gemeentebesturen.

Uitgaande van de in eigendom verkregen grond kan men stellig spreken van een doelmatige, rationele verkaveling en landinrichting, zoals te verwachten is bij een dergelijke georganiseerde kolonisatie. De kavels van \pm 3 ha waren rechthoekig en alle aan een weg gelegen.

Hiermee is uiteraard niet gezegd, dat de indeling van de grond in dergelijke kleine bedrijfjes van 3 ha een gelukkige opzet is geweest. De opvatting van Van den Bosch, dat een ontginningsbedrijf van deze of zelfs nog kleinere oppervlakte aan een gezin van zes personen een volledig bestaan zou kunnen bieden, was onjuist, ook in de ogen van tijdgenoten. 
Men raakt hier aan de meest fundamentele vergissing, die bij de aanleg van de koloniën is gemaakt en zich tot de reorganisatie van 1859 is blijven wreken. Toen de Maatschappij omstreeks 1827 tot het inzicht kwam, dat de bedrijven zeker tweemaal zo groot moesten zijn, had men bedrijfsvergroting moeten toepassen. Het is aannemelijk, dat men terugschrok voor de financiële consequenties van een dergelijke ingreep.

Van meer belang is waarschijnlijk geweest, dat het bestuur inmiddels het besef had gekregen, dat het aanvankelijke plan de kolonisten tot min of meer zelfstandige bedrijfshoofden (vrijboeren of pachters) op te leiden, niet voor uitvoering vatbaar was. Slechts weinige kolonisten waren naar hun aard en capaciteiten geschikt voor het vrijboerschap. De grote meerderheid bleef kolonist-arbeider. Men kan dus concluderen, dat de Maatschappij zelf exploitant was en bleef van vrijwel alle cultuurgrond.

Het is dan ook onbegrijpelijk, dat men niet terstond is overgegaan tot een teeltplan, dat was gebaseerd op een perceelsindeling overeenkomstig de verkaveling van de hoeven. Anders gezegd: een vruchtwisseling, waarbij elke hoeve als één perceel grond met één bepaald gewas werd beteeld, zou een grote vereenvoudiging in de bedrijfsvoering hebben betekend. De Maatschappij zou in dit geval tevens op een doeltreffende wijze toezicht hebben kunnen uitoefenen op de gang van zaken.

In de praktijk zette men in de koloniën de landbouw voort, alsof elke kolonist een zelfstandig bedrijf beheerde. Zelfs na de beperkte reorganisatie van I 836 en volgende jaren werd op elke hoeve een afzonderlijke vruchtwisseling uitgevoerd. Dit systeem leidde tot een onoverzichtelijke chaos in het grondgebruik.

De verschillende vruchtwisselingssystemen, die achtereenvolgens zijn toegepast, hadden de afwezigheid van blijvend grasland gemeen. De Maatschappij bezat slechts weinig wei- of hooiland langs de Vledder Aa. Op de ontginningsgrond is uitsluitend akkerbouw in de vorm van wisselbouw uitgeoefend. In het algemeen lag het accent sterk op de rogge en aardappelen, zodat te weinig voedergewassen werden verbouwd om een veestapel te kunnen voeden, die voldoende stalmest opleverde. Ook na de eerste ontginningsjaren bleven de mestaankopen schering en inslag. Op alle mogelijke wijzen trachtte de Maatschappij de beschikking te krijgen over een maximale hoeveelheid mest van mens en dier. Uitvoerige voorschriften waren van kracht voor de mestverzameling en -conservering. In deze reglementen waren zeker goede gedachten verwerkt, tevens geven zij blijk van het levensbelang, dat de Maatschappij hechtte aan de mestvoorziening. Alle stoffen, die maar enigszins bruikbaar waren, werden 
benut. Ook de invoering van de teelt van brem als groenbemester, met de verbouw van aardappelen als nagewas zonder of met gedeeltelijke gewone bemesting, getuigt van de vindingrijkheid van Van den Bosch. De resultaten van de bremcultuur waren echter wisselvallig en zeker niet van dien aard, dat zij de voortzetting van deze teelt rechtvaardigden.

Op zichzelf beschouwd vertoonde de vruchtwisseling enkele vooruitstrevende onderdelen, die in de omgeving van de koloniën onbekend waren. Als zodanig is te noemen het intensieve bouwplan met voedergewassen als onderteelt na rogge. De verbouw van rode klaver, fiorinen raaigras als kunstweiden behoort mede tot de aspecten van de koloniale landbouw, die navolging verdienden. De voorbeeldfunctie van de koloniën is in landbouwkundig opzicht echter van zeer beperkte betekenis geweest.

Ondanks het feit, dat de veestapel te gering was om in de mestbehoefte te kunnen voorzien, is de veedichtheid voortdurend te groot geweest in verhouding tot de beschikbare oppervlakte voedergewassen. Het gevolg was dan ook een vrijwel jaarlijks terugkerende noodzaak tot aankoop van grote hoeveelheden hooi.

Wanneer men in aanmerking neemt, dat de opbrengstcijfers in de koloniën doorgaans lager waren dan het normale niveau in Drenthe en Overijssel, zowel van de rogge en aardappelen als van de veehouderij, kan de algemene eindconclusie zijn, dat de Maatschappij van Weldadigheid met het gekozen landbouwstelstel onvoldoende resultaten heeft bereikt in de periode van 18 I 8 tot 1859 . Het getuigt van een zekere mate van eigenzinnigheid van Van den Bosch en het bestuur, dat men in dit tijdvak geen drastische hervorming heeft uitgevoerd, die tegemoetkwam aan de door verscheidene waarnemers gedane aanbeveling de veehouderij uit te breiden ten koste van de akkerbouw. Bij een grotere oppervlakte cultuurgrond per gezin en een meer gemengd bedrijfstype zouden de uitkomsten van de koloniale landbouw waarschijnlijk gunstiger zijn geweest. Het zal echter duidelijk zijn, dat bij een onderneming als dit kolonisatieproject de onbekendheid met en gedeeltelijke ongeschiktheid van de kolonisten voor de landbouw, zelfs bij overigens optimale bedrijfsomstandigheden en bedrijfsvoering, een negatieve factor vormen. De bedrijfsresultaten worden hierdoor onvermijdelijk ongunstig beïnvloed. Dit aspect is echter inherent aan de sociale oogmerken van een dergelijke kolonisatie. De koloniën van de Maatschappij van Weldadigheid mogen zeker worden aangemerkt als een sociaal-economisch en landbouwkundig experiment van de eerste orde, dat in de eerste helft 
van de i gde eeuw dan ook in het middelpunt stond van de belangstelling van filantropen, economen en landbouwkundigen.

\section{OVERZICHT VAN DE ONTWIKKEIING NA I 859}

Op I 6 september I 859 nam het Rijk de gestichten te Ommerschans en Veenhuizen van de Maatschappij van Weldadigheid over mét de directeur Van Konijnenburg. Door een gunstige financiële regeling met de Regering kon de Maatschappij zich voortaan uitsluitend gaan toeleggen op de verdere ontwikkeling van de koloniën te Frederiksoord en omgeving, zonder gebukt te gaan onder een zware renteverplichting en een grote schuld.

Ook dit summier overzicht van de gang van zaken sedert i 859 beperkt zich tot de landbouwkundige aspecten. Hoewel deze verscheidene belangwekkende details opleveren, zal op deze plaats moeten worden volstaan met een schets van de grote lijnen. Een periode van meer dan een eeuw laat zich in enkele bladzijden niet in bijzonderheden weergeven ${ }^{x}$.

Verscheidene aanbevelingen van critici, die de Permanente Commissie voordien in de wind had geslagen, zijn in de jaren na 1859 door het toen optredende College van Commissarissen ten uitvoer gebracht. Als belangrijkste wijziging op landbouwgebied is melding te maken van de reorganisatie van het grondgebruik. Door samenvoeging van de grond van de kolonisten-arbeiders ontstonden in I $864-I 867$ zes grote boerderijen van omstreeks 50 ha, elk met een modern bedrijfsgebouw, die de Maatschappij onder toezicht van bedrijfsleiders in eigen exploitatie nam. Hiervoor was een verhuizing van 50 vrijboeren- en 50 arbeidersgezinnen noodzakelijk. Het bedrijfskapitaal was ten dele verkregen uit de verkoop van het gebied van het Instituut voor den Landbouw te Wateren en omgeving in $\mathrm{r} 860$ voor $f 88.868$, - bruto, d.i. bijna $f 50.000$, - minder dan de balanswaarde. Te Frederiksoord stichtte de Maatschappij de hoeve "Koning Willem III”, te Wilhelminaoord de hoeven „De Dankbaarheid” en "'s-Gravenhage" en te Willemsoord de hoeven "Utrecht”, "Generaal Van den Bosch" en "Amsterdam”.

In elke boerderij was stalruimte voor 24 stuks grootvee, 42 stuks jongvee en 8 paarden. De melk werd gebruikt voor de mesterij van kalveren en varkens. Het hoofddoel van de veehouderij was de mestproduktie. Tevens voerde de nieuwe directeur Jongkindt Coninck (later de eerste directeur van de Rijkslandbouwschool te Wageningen) vele proeven uit om vergelijkingen te kunnen trekken tussen een groot aantal „hulp- en kunstmeststoffen”, zoals guano, wollen lompen, 
ammoniakzout, potas, gips en Chilisalpeter ${ }^{2}$. Door de resultaten van deze en andere proeven te publiceren vestigde de Maatschappij de aandacht van de landbouwkundigen steeds meer op Frederiksoord en omgeving.

In I 864 en volgende jaren schreef de directeur in de LandbouwCourant vele artikelen over de landbouw in de koloniën, o.a. over rijenteeltproeven met rogge en haver, over de opbrengstcijfers, bemestingsproeven en proeven met de teelt van erwten, wikken en haver als groenvoer, mengsels van spurrie en serradella en reuzeklaver. De bremcultuur is na I 859 nog slechts op enkele percelen toegepast, hoewel Jongkindt Coninck hier niet geheel afwijzend tegenover stond.

In een uitvoerig artikel heeft de directeur de reorganisatie van de landbouw beschreven ${ }^{3}$. Als belangrijkste punten wordt hier nog het volgende vermeld. Het bouwplan was gebaseerd op wisselbouw. Blijvend grasland achtte men op de ontginningsgrond niet mogelijk. Het gehele jaar door paste de Maatschappij op de grote boerderijen stalvoedering toe. Het aantal slagen van de vruchtwisseling was gelijk aan het aantal voormalige hoeven van $\pm 2 \frac{1}{2}$ ha, waaruit de grote bedrijven waren opgebouwd. Elk perceel van $2 \frac{1}{2}$ ha droeg dus slechts één gewas, hetgeen een grote verbetering betekende ten opzichte van de vroegere situatie. De vruchtwisseling bestond bij nadere beschouwing uit 7 of 8 slagen, drievoudig uitgevoerd. Het systeem was gebaseerd op het grondplan:

I. aardappelen;

2. erwten of bonen;

3. rogge;

4. snijrogge, spurrie, boerenkool of knollen;

5. gerst of haver met als nagewas klaver en gras;

6. klaver- en graskunstweide;

7. idem.

De Maatschappij schafte een groot aantal gereedschappen en werktuigen aan, ten dele uit Engeland en Amerika via de heer Boeke te Groningen. Men gebruikte niet minder dan vier soorten ploegen en eveneens vier modellen ondergrondsploegen, die onderling werden vergeleken. Hiermede is nog slechts een klein gedeelte van het assortiment werktuigen genoemd.

De koloniën bestonden in 1865 uit I 200 ha bouwland, roo ha bos, 600 ha heide en 100 ha wegen, pleinen en erven, zodat de totale oppervlakte \pm 2000 ha bedroeg. De bevolking telde \pm 2400 zielen. De kolonisten-arbeiders ontvingen sinds 1859 weer hun loon in aangenomen werk, uitbetaald in normaal Nederlands geld. Het stelsel met een 
minimum- en maximumloon is afgeschaft. Het aantal vrijboeren (pachters), in I 859 niet meer dan 20 , is de volgende jaren sterk vergroot. In 1860 en I 86 I zijn 160 arbeiders gepromoveerd tot vrijboer. Hun aantal bedroeg in 1865 niet minder dan 242 .

$\mathrm{Na}$ I 859 is een grote oppervlakte slechte landbouwgrond en heide bebost, vooral in het gebied van kolonie vII, later Boschoord genoemd. De bosbouw werd een belangrijke bron van werkgelegenheid in de koloniën. Tevens werd sinds I 870 aanvullende werkgelegenheid geboden in de mandenmakerij, touwslagerij en de weverij van koedekken. De produkten werden ook buiten de koloniën verkocht. Op een tentoonstelling van de Hollandsche Maatschappij van Landbouw te Purmerend verwierf de Maatschappij van Weldadigheid in 18 jo voor haar koedekken een bestuursprijs.

De belangstelling van landbouwkundigen voor de landbouw te Frederiksoord en omgeving blijkt uit de volgende uitspraak van Staring4 :

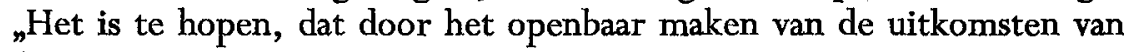
den landbouw der 4000 hectaren, welke bij deze gestichten ${ }^{5}$ behooren, evenzeer als van dien der 400 ha in eigen bouw door de Maatschappij van Weldadigheid beheerd, meer dan tot dusverre geschied is, de aandacht op die zoo reusachtig in 't groot gedreven proefboerderijen gevestigd worde. De beoordeling van die bouwerijen, als inrichtingen tot bestrijding van armoede, moet aan staathuishoudkundigen en menschenvrienden worden overgelaten, aan den wetenschappelijken landbouwer past het om ze te beoordeelen als landbouwondernemingen, en om nutte leeringen in menigte te trekken uit hetgene daar omgaat".

In het pachtsysteem, dat nog steeds was vastgelegd op een jaarpacht $\operatorname{van} f 5^{\circ}$, - voor de vrijboerhoeven van $2 \frac{1}{2} \mathrm{ha}$, kwam in 1876 een wijziging. Bij elke verhuring aan een nieuwe vrijboer kreeg het bestuur de vrijheid een andere pachtsom vast te stellen, overeenkomstig een door buitenstaanders uitgevoerde taxatie, in verband met de verschillen in bodemvruchtbaarheid.

Nadat in 1875 was meegedeeld, dat de opbrengst van de kunstweiden afnam, constateerde het bestuur: „Het stelsel van vaste weiden moet dan ook meer en meer op den voorgrond komen". In 1879 waren op de grote boerderijen vaste, omheinde weilanden aanwezig. De vorming van een goede zode duurde betrekkelijk lang. Het vee werd nog gedeeltelijk getuierd of gehoed.

Wegens de lage prijzen van de vette kalveren besloot de Maatschappij in 1880 over te gaan op de verwerking van melk tot boter volgens het nieuwe Deense koudwatersysteem. Hiertoe kwam in maart $188 \mathrm{I}$ bij de 
hoeve „De Dankbaarheid” een botermakerij gereed, die ook de melk van de hoeven „Koning Willem III" en „'s-Gravenhage” en van een aantal vrijboeren centraal verwerkte. Ook is aan dit zuivelfabriekje een kaasmakerij verbonden, die in 1882 in bedrijf werd genomen.

In hetzelfde jaar is te Wilhelminaoord door een particulier uit Leiden een conservenfabriek gesticht, die jam en blikgroenten produceerde. De grondstof werd betrokken van een bij de fabriek behorende moestuin en van de kolonistentuinen. Hierdoor breidde de tuinbouw in de koloniën zich uit. In $\mathrm{r} 887$ is deze fabriek echter verplaatst naar Beverwijk.

Ook in 1882 nam de Maatschappij enkele proeven met het inkuilen van gras, klaver, koolraapblad en mais met bevredigend resultaat. Deze proefnemingen zijn in het volgende jaar op grotere schaal voortgezet.

De centrale melkinrichting te Wilhelminaoord ontving sedert $188_{3}$ ook de melk van de drie boerderijen te Willemsoord. Met de boterfabricage werd succes geboekt; op een tentoonstelling van het Drentsch Landbouwgenootschap behaalde de Maatschappij uit 2 I inzendingen de eerste prijs.

De uitkomsten van landbouw en veeteelt ontwikkelden zich echter, ondanks de ingrijpende hervormingen, niet naar wens. In de tien jaren van 1874 - I 883 kocht de Maatschappij per jaar gemiddeld voor bijna

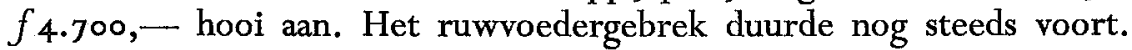
Hoewel in de periode 1867 tot en met 1885 gemiddeld een kleine jaarlijkse winst van $f 2.35^{\circ}$, - werd behaald op de landbouw en veehouderij in eigen beheer, was in 1884 sprake van financiële nood.

De melkproduktie per koe ging evenwel vooruit, hetgeen men bevorderde door aankoop van beste Friese stieren en het bijhouden van melkcontrôleregisters. De Maatschappij ging rond 1885 steeds meer stamboekkoeien gebruiken voor de fokkerij. Ter verbetering van de varkensstapel werd een volbloed Yorkshire beer gekocht.

Op onderwijsgebied is vermeldenswaard de stichting van een drietal scholen voor voortgezet agrarisch onderwijs. Hiertoe is de Maatschappij in staat gesteld door een belangrijke gift van de majoor der Cavalerie b.d. F.H.L. van Swieten te Delft. Zo is in oktober I 884 de thans nog bestaande Gerard Adriaan van Swieten Tuinbouwschool te Frederiksoord geopend. In januari i 888 volgde de G.A. van Swieten Bosbouwschool, eveneens te Frederiksoord gevestigd in het huidige kantoorgebouw van de Maatschappij. Deze school is in 1902 opgeheven wegens het te geringe aantal leerlingen. Tenslotte opende men in oktober 1890 een landbouwvakschool in het hiertoe aangekochte huis „De Ronde Blesse” nabij Willemsoord. Deze school is gesloten in $190 \mathrm{I}$ in verband met de op- 
richting van verscheidene landbouwwinterscholen in andere plaatsen.

De zuivelfabriek te Wilhelminaoord werkte niet met voordeel. Een noodzakelijke modernisering zou ongeveer $f$ r 2.000 , - kosten. Daar de Maatschappij dit bedrag niet kon investeren, is de fabriek op 3 I december I 893 opgeheven. De melk werd tot 1898 aan een naburige zuivelfabriek verkocht.

Het nijpende gebrek aan financiële middelen noopte in 1895 tot verkoop van 14 kolonistenwoningen met grond (ruim 48 ha) en ruim 23 ha bos en heide aan de Paasloregel te Willemsoord, getaxeerd op $f$ i 8.000,Deze eerste verkoping, die slechts $f$ I $3.700,-$ opbracht, was het begin van de verdere inkrimping van het onroerend eigendom van de Maatschappij. Het volgende jaar moest men nog een aanvullende lening van $f 40.000$,- - sluiten.

Inmiddels was sedert I 865 het bosareaal van roo ha uitgebreid tot 445 ha in 1895 , hoofdzakelijk door bebossing van zandverstuivingen en heideveld in kolonie vII (Boschoord). Teneinde tot een economischer beheer van de bossen te komen is in 1896 door de Heidemaatschappij een rapport uitgebracht over de bosbouw. Hoewel enkele goede bossen voorkwamen, ontbrak er heel wat aan de verzorging van het bosbezit.

Met betrekking tot de boerderijen in eigen beheer kan worden vermeld, dat de hoeve "Utrecht” in $x 888$ werd herbouwd, omdat deze in een slechte toestand verkeerde. "De Dankbaarheid” in Wilhelminaoord heet sinds I 895 hoeve „Prinses Marianne” naar de naam van de schenkster, die destijds de middelen voor de bouw verschafte. In het verslag over 1896 is voor de eerste maal ook sprake van de hoeve „Boschoord” in kolonie vII, zodat de Maatschappij toen 7 boerderijen exploiteerde.

De koloniën hebben het slechts vier jaren zonder zuivelfabriek moeten stellen. In juli 1898 is op de plaats van de vroegere melkinrichting de stoomzuivelfabriek „Deli” geopend. De bouw is bekostigd uit een gift van de Amsterdamse oud-planter P. W. Janssen. Deze fabriek is gesticht op coöperatieve grondslag met 263 leden, wonende in en buiten de koloniën, die de melk van ruim 700 koeien leverden.

Dezelfde milde gever had reeds in I 893 de bouw van het bejaardentehuis „Rustoord” mogelijk gemaakt, terwijl hij in I 897 ook de telefoonaanleg in de koloniën bekostigde en een bedrag fourneerde voor de aankoop van \pm 2 I ha heide in het Vledderveen. Deze woeste grond was bestemd voor ontginning en stichting van één of meer boerderijen. In de volgende jaren is hier de boerderij „Rustoord” ontstaan, die in $190 \mathrm{I}$ gereedkwam. De opbrengst was bestemd voor het bejaardentehuis.

Een vermeldenswaardige proef op het gebied van de veefokkerij was 
de kruising van „ons klein Drentsch koetje” met Jersey-vee. Hiertoe zijn in I 899 twee Jersey-koeien uit Engeland ingevoerd. Zij leverden melk met een vetgehalte van $7,4 \%$.

Doordat nog slechts incidenteel nieuwe kolonistengezinnen in de koloniën werden opgenomen, ook om redenen van bezuiniging, kwamen steeds meer kolonistenwoningen en grond vrij van bewoning. Per ultimo I 896 werden 37 vrijboerhoeven en 59 arbeiderswoningen door de Maatschappij verhuurd aan personen van buiten de koloniën, die ook na hun vestiging niet tot de eigenlijke koloniale bevolking werden gerekend.

De vermindering van het aantal kolonistengezinnen maakte het ook mogelijk vrijboeren in de gelegenheid te stellen hun bedrijfjes van 3 ha te vergroten met vrijgekomen grond van andere vrijboerhoeven. Sinds het einde van de Igde eeuw heeft de Maatschappij op deze wijze bedrijfsvergroting toegepast in het belang van de vrijboeren, die feitelijk meer en meer gewone pachters werden.

Bij de eeuwwisseling had de Maatschappij 400 ha cultuurgrond in eigen exploitatie, w.o. de zes oorspronkelijke boerderijen van $5^{\circ}$ ha en r 00 ha verspreide percelen, meest grasland, o.a. in Boschoord en langs de Vledder Aa. Op elke boerderij was 15 ha blijvend grasland, io ha kunstweide van rode klaver en Italiaans raaigras en $\mathrm{I}_{3}$ à $\mathrm{I}_{4}$ ha andere voedergewassen. zoals duivebonen, bruine bonen, voederbieten, koolrapen en serradella. Ongeveer de helft van elke hoeve werd gebruikt voor voederbouw, de andere helft voor rogge, aardappelen en haver.

Bij dit teeltplan hield men per boerderij ruim 20 melkkoeien, Io pinken, ro kalveren, 3 paarden en 2 trekossen. Zomerstalvoedering werd niet meer toegepast; volledige weidegang was mogelijk. Hoewel het grasland alleen kunstmest kreeg, kon men nog hooi verkopen. In de potstallen werd soms nog gestrooid met heideplaggen. De melkopbrengst bedroeg per stal gemiddeld wel eens $3000 \mathrm{~kg}$ per koe per jaar, terwijl het vetgehalte kon stijgen tot $4 \frac{1}{2} \%$, bij de koeien van vrijboeren soms tot $5 \%$.

Het totale grondbezit besloeg omstreeks I 900 een oppervlakte van 2030 ha, w.v. 1300 ha cultuurgrond, 400 ha bos, 30 ha hoogveen en 300 ha heide 6 .

De eigen exploitatie van de landbouwbedrijven leverde afwisselend winst en verlies op. De Maatschappij als geheel had echter voortdurend met verlies te kampen, hetgeen werd toegeschreven aan de hoge administratiekosten, de kosten van het onderwijs, de overwegend stedelijke herkomst van de bevolking en het feit, dat de beste arbeidskrachten de Maatschappij verlieten. Tegen deze achtergrond nam het bestuur het 
belangrijke besluit de eigen landbouwexploitatie in te krimpen door in 190 I de hoeve "Generaal Van den Bosch" te Willemsoord, die het minst opbracht, te verpachten. In het volgende jaar is ook de boerderij "Amsterdam", eveneens te Willemsoord, verpacht.

Op de bedrijven in eigen beheer bleek op den duur de veeteelt rendabeler te zijn dan de akkerbouw. Men streefde daarom naar uitbreiding van het blijvend grasland en de veestapel. In dit licht dient men ook de proeven te zien met kruisingen van landvarkens en Yorkshire varkens en van Jersey en Friese stieren met Drentse koeien. Het verlies, dat de boerderijen in eigen beheer vaak opleverden, werd ook veroorzaakt door het filantropisch karakter van de werkverschaffing. Zo gaf de Maatschappij op één hoeve van ruim 48 ha in 1904 aan arbeidsloon $\pm f 4.000$, - uit aan de wijkmeester ( $=$ bedrijfsleider) en I 8 arbeiders, die het gehele jaar werk vonden. De Zeeuwse pachter van de hoeve „Generaal Van den Bosch" had evenwel slechts ro man vast in dienst.

De nieuwe hoeve "Rustoord" is in 1906 eveneens verpacht. Van de acht grote boerderijen waren sindsdien nog vijf hoeven in eigen exploitatie. Inmiddels had de Maatschappij de ontginning van heideveld op grotere schaal weer hervat. Ten dele werd de woeste grond ontgonnen tot grasland, maar vooral is de bebossing uitgebreid. De bosbouw ontwikkelde zich tot een belangrijke bedrijfstak in het gebied van de Maatschappij.

In 1910 bestond het grondbezit uit ongeveer 2400 ha, waarvan I roo ha landbouwgrond, I 000 ha bos, 300 ha heide en ro ha kwekerij van bosplantsoen (o.a. larix). Van de kolonistenwoningen waren $\mathrm{I}$ ro als kleine boerderijen verpacht aan vrijboeren, 80 bewoond door kolonistenarbeiders en $4^{\circ}$ verhuurd als burgerwoningen aan niet-kolonisten ${ }^{7}$.

Omdat de gebouwen van de boerderijen "'s-Gravenhage” en „Prinses Marianne" in zeer slechte staat waren, besloot men deze in 1913 af te breken en te vervangen door één nieuwe boerderij met \pm 80 ha cultuurgrond. De resterende grond van de niet herbouwde "'s-Gravenhage" werd verpacht aan enkele vrijboeren. De nieuw gebouwde „Prinses Marianne" kwam in r914 in gebruik. De hoeve "Willem III" is in I9I 7 verbouwd.

De oorlogsjaren brachten de Maatschappij ongekend grote winsten, vooral op de bosbouw. Door aankoop verwierf men in I 9 I 8 de boerderij "De Werkhorst" in eigendom met 25 ha land, gelegen bij Boschoord. Door ontginning van een aangrenzend heideperceel werd dit een bedrijf van $5 \mathrm{x}$ ha, in eigen beheer. Eveneens door ontginning is in $192 \mathrm{I}$ de boerderij „Immer Moed" gesticht ter grootte van $20 \mathrm{ha}$, die ook in eigen beheer werd genomen. 
De slechte financiële uitkomsten van de naoorlogse jaren noopten de Maatschappij in 1922 te besluiten over te gaan tot verkoop van Willemsoord, voorhands met uitzondering van de drie grote hoeven „Gen. Van den Bosch”, „Utrecht” en „Amsterdam” en de bossen. De opbrengst zou men kunnen gebruiken voor schulddelging en ankoop van heideveld voor ontginning tot nieuwe boerderijen. Deze beslissing betekende een belangrijke inkrimping van de bezittingen der Maatschappij. In de jaren 1923-1958 zijn successievelijk alle eigendommen te Willemsoord, inclusief de grote boerderijen, publiek verkocht. Van de oorspronkelijke koloniën zijn sindsdien Frederiksoord, Wilhelminaoord en Boschoord eigendom van de Maatschappij gebleven. $\mathrm{Na} \mathrm{I}_{927}$ is ook het in Friesland gelegen deel van Wilhelminaoord vrijwel geheel in andere landen overgegaan.

Overeenkomstig het plan is in 1926 een aanvang gemaakt met de ontginning van 350 ha aangekochte heide onder Doldersum. Dit gebeurde met trekker en ondergrondsploeg. Bij de ontginning van andere percelen wilde de Maatschappij zich toeleggen op de tewerkstelling van werklozen en zo mogelijk vestiging van jonge boeren op nieuw te stichten bedrijven. Zoals de directeur in 1925 opmerkte: „Het is een feit, dat het plaatsen van gezinnen, zoals oorspronkelijk het doel van de Maatschappij was, den laatsten tijd wel eenigermate in het gedrang is gekomen ... een gevolg van de omstandigheid, dat de menschen in de groote steden worden gesteund ..."

Hoewel ook nog na 1900 tot in de dertiger jaren aan verscheidene afdelingen van de Maatschappij het recht tot plaatsing van een gezin in de koloniën is verleend, heeft men hiervan slechts sporadisch gebruik gemaakt. Sinds 1920 is alleen in 1927 en in 1931 nog een gezin door bemiddeling van een afdeling opgenomen. Het is dan ook begrijpelijk, dat het aantal inwoners van de koloniën (incl. ambtenaarsgezinnen) tussen I 9 I 8 en I 940 daalde van 1774 tot 875 personen.

In $1928 \mathrm{kwam}$ bij Doldersum als nieuwe ontginningsboerderij de "Sophiahoeve" met 40 ha cultuurgrond gereed, die voor de eerste jaren in eigen beheer werd genomen. Het lag in de bedoeling nog 12 à I 3 andere boerderijen te stichten. Aan dit plan is echter slechts ten dele uitvoering gegeven. Zo zijn te Frederiksoord in 1929 nog twee pachtboerderijen gebouwd, elk met $\mathrm{I}_{4}$ ha wei- en bouwland. Overigens ging men door met bedrijfsvergroting door samenvoeging van vrijboerhoeven tot 6 - I 2 ha.

Wegens het voortdurende grote verlies op de eigen exploitatie zijn in r 935 de drie boerderijen „Marianne”, „Immer Moed” en „Sophiahoeve” 
met een totale oppervlakte van Ior ha verpacht. In eigen exploitatie resteerden nog „Willem II" met 70 ha en "Boschoord” met 40 ha. Ook is de zuivelfabriek "Deli” in dit jaar opgeheven. Door het hoge onkostencijfer lag de uitbetaalde melkprijs per liter 0,5 cent lager dan bij een andere fabriek in de omgeving. In I 950 heeft de hoeve „Boschoord” een andere bestemming gekregen als verpleeginrichting voor \pm 30 mannelijke onmaatschappelijke debielen. Tenslotte heeft de Maatschappij in 1 955 de eigen landbouwexploitatie geheel beëindigd door ook de hoeve "Willem III" te verpachten.

De achtereenvolgende wijzigingen in de exploitatie van haar bezittingen hebben belangrijke gevolgen gehad ten aanzien van de structuur van de bevolking. In Frederiksoord en Wilhelminaoord wonen thans op if boerderijen nog afstammelingen van kolonisten, die zich vóór $185^{\circ}$ hebben gevestigd. Bovendien zijn in het gebied van de Maatschappij ro gezinnen woonachtig, waarvan het hoofd als werknemer zijn bestaan vindt in de land-, tuin- of bosbouw en eveneens afstamt van oorspronkelijke kolonisten van vóór 1850 . Dit laatste geldt eveneens voor I 4 andere gezinnen, waarvan het gezinshoofd buiten de agrarische sector werkt, en voor 7 weduwen of weduwnaren en 10 bejaarden.

In totaal kan men dus van de huidige bewoners van Frederiksoord en Wilhelminaoord $4^{\mathrm{I}}$ gezinnen en 17 alleenstaanden beschouwen als nakomelingen van kolonisten uit de periode tot $185^{\circ}$. Het is opvallend, dat deze bevolkingsgroep in overwegende mate de oorspronkelijke tongval heeft bewaard. In zekere zin kan men nog steeds spreken van een „Hollandse enclave” in de provincie Drenthe.

De activiteiten van de Maatschappij (sinds 1960 niet meer als vereniging, maar als stichting werkzaam) bepalen zich thans in de agrarische sector tot het beheer van $77^{\circ}$ ha bos in eigen exploitatie en $64^{\circ}$ ha cultuurgrond, verdeeld over 37 landbouwbedrijven, 66 ha los verpacht land, de Van Swieten Middelbare Tuinbouwschool met i 3 ha cultuurgrond en de boerderij van i I ha, behorende bij de hoeve „Boschoord”. Van de 37 verpachte landbouwbedrijven zijn thans nog slechts 3 kleiner dan 5 ha, 24 zijn $5-15$ ha groot en 10 groter dan I 5 ha. Met 320 ha woeste grond, 43 ha huizen, tuinen en erven en 37 ha wegen en waterlossingen heeft de stichting $18 \times 0$ ha in eigendom, hoofdzakelijk in de gemeente Vledder ( 16 ha in Friesland). De bosbouw en de kwekerij van laanbomen en kerstbomen ( $\pm 6 \mathrm{ha}$ ) vormen de belangrijkste bron van inkomsten. De exploitatie van de overige vaste goederen (verpachte boerderijen en los land, \pm roo verhuurde woningen) levert doorgaans een verlies op door de grote onderhoudskosten van de verhuurde gebouwen. 
Op sociaal gebied houdt de stichting zich bezig met het ter beschikking stellen van een gedeelte van de hoeve "Willem III" voor de organisatie van kindervakantiekampen. Voor de bewoners van Frederiksoord en Wilhelminaoord steunt men de exploitatie van het Dorpshuis. Van betekenis voor een wijdere omgeving is de huisvesting en verzorging van bejaarden in Rustoord I, bestaande uit 8 bejaardenwoningen, en Rustoord II, waarin omstreeks 40 personen verzorging hebben gevonden. De bouw van een nieuw bejaardentehuis is in voorbereiding. Door bemiddeling van de stichting is in Schoonebeek een aantal minder-valide arbeiders werkzaam bij de aanleg en het onderhoud van beplantingen en plantsoenen. Ten slotte exploiteert men de hoeve "Boschoord” als een open inrichting tot verpleging van $20-30$ debiele of asociale jongemannen, die ter beschikking van de regering zijn gesteld. Zij zijn o.a. werkzaam op de leerboerderij "Eikenhof" en in de bossen.

Zo zijn in de loop van bijna 150 jaar belangrijke wijzigingen opgetreden in de functie van de Maatschappij van Weldadigheid. In de eerste helft van de 19 de eeuw heeft dit particulier initiatief een voorbeeld gegeven van georganiseerde werkverschaffing door ontginning van woeste grond en stichting van landbouwkoloniën. Vervolgens exploiteerde de Maatschappij een aantal grote landbouwbedrijven, die vooral in de tweede helft van de vorige eeuw een voorbeeldfunctie op landbouwkundig gebied uitoefenden. Thans kan men dit in zekere zin nog zeggen van het bosbouwbedrijf. In de laatste decennia tracht het bestuur op sociaal terrein nieuwe wegen te vinden, die kunnen leiden tot een voortzetting van de sociale arbeid van Johannes van den Bosch, thans aangepast aan de omstandigheden van de moderne welvaartsstaat. 


\section{SUMMARY}

$\mathrm{I}^{\mathrm{N}}$

N 1818 the Benevolent Society of Holland was founded as a private society aiming at the reclamation of vast areas of waste land, suitable for agriculture, and there to establish settlements of poor families migrating from the towns. The Society succeeded in buying large tracts of waste land on sandy soil with some peat, covered with heath and situated between the towns of Assen and Steenwijk along the borders of the provinces of Drenthe, Friesland and Overijssel in the northern part of the Netherlands.

Agricultural colonies were founded in the years 1818 till 1823 as settlements for the relief of the poor. They demanded large investments which were non-profitable in an economic sense. The social profits cannot be evaluated in terms of money. In the absence of a clear and permanent policy of government subsidies the Benevolent Society was obliged to do its utmost to keep the financial loss in check by means of a strict administration, also with regard to agriculture.

Actually the Society did not start with experimental colonisation on a small scale. Without any certainty as to the success of the project, the Society not only carried out colonisation at a relatively high speed, but at the same time also bought far more waste land than afterwards appeared to have been necessary. In I 859 less than $40 \%$ of the surface in the region of the free pauper colonies was lying in arable land.

The geographic location of the colonies of Frederiksoord, Willemsoord and Wilhelminaoord and the Agricultural Institute (one of the earliest agricultural schools in the country) at Wateren presented great difficulties in respect of efficient administration and supervision.

It may be asserted that within the borders of the property owned, the system of land-allocation was rational and suitable, as might be expected in organised colonisation-projects of this kind. The parcels of about 3 hectares each ( $\pm 7,5$ acres) were square and situated along the roads.

The land was divided into a great number of small farms, consisting 
of one 3 hectare parcel each. The conception of the founder, General Van den Bosch, that farms of this size and even smaller offered complete subsistence to a family of six persons, proved to be wrong, as contemporary agronomists had foreseen.

This has certainly been the most fundamental mistake until the year of reorganisation ( 1859 ). When the Society discovered in 1827 that the farms should have been twice this size, they did not do anything in the way of readjustment, probably because of the financial consequences of such a reorganisation.

In the meantime the board of administration considered it impossible to execute the original plan of education and training which aimed at the colonists becoming more or less independent free farm operators (tenants). Only few colonists possessed the attitude and ability required for free farmers. The great majority remained colonists-labourers. The Society was the operator of almost all the arable land.

This could have been remedied by the Society introducing a farming plan based on a parcelling in accordance with the allocation of the original small holdings. In other words : a production plan dealing with each small farm as one parcel with one crop so as to simplify management.

The Society continued farming as if each colonist were in charge of an independent holding. Even after the limited reorganisation of 1836 each holding carried a seperate rotation of crops. This system led to complete chaos in the utilisation of the arable land.

The different crop-rotation schemes applied in the period I 8 I 8 - I 859 had the absence of permanent grazing in common. The Society possessed only a small area of permanent pasturage along the river. The former waste land was cultivated for field crops only, although fodder crops were included in the rotation. In general the accent was laid on rye and potatoes. Too few fodder crops were grown for the number of cattle required to produce sufficient manure. The purchase of manure became a permanent item.

On the other hand detailed rules were introduced for the collection and conservation of manure from animals and men. These regulations indicate the great importance the Society attached to the supply of manure. All possible stuffs were used. Also the introduction of broom as a fertilising crop, with potatoes afterwards either with or without an admixture of ordinary manure, is an indication of the inventiveness of Van den Bosch, though he borrowed the idea from the Flemish farmers. The cultivation of broom resulted in a succession of ups and downs, which did not justify the continuation of this crop. 
The crop rotation however did contain some modern elements unknown in the surroundings of the colonies. As such is to be mentioned the intensive cropping scheme with fodder crops after rye. The growing of red clover, fiorin and ryegrass as artificial grassland was one of those aspects of "colonial” agriculture, which deserved attention from outside the colonies.

In spite of the fact that the number of cattle was insufficient to cover the demand for manure, the density of cattle has always been too high in relation to the area of fodder crops. Owing to this disparity large quantities of hay had to be bought practically every year.

Regarding the crop yields per hectare and the yields per animal it is clear that the figures were usually relatively low compared with the normal ones in the provinces of Drenthe and Overijssel. The general conclusion may be that the Society obtained insufficient results with the chosen system of agriculture in the period of 1818 till 1859 . A certain measure of obstinacy on the part of the board of administration is evidenced by their refusal to introduce drastic reforms in accordance with the recommendations of several qualified observers who advocated more animal husbandry and less field crops. Probably the results of "colonial" agriculture would have been more favourable if there had been a larger area of cultivated land per family and a more mixed type of farming.

. It will be clear however that, even in optimal other circumstances of farm management, a negative factor is still formed by the fact that colonists in projects of this kind are not familiar with agriculture and partially unable to work in it. One cannot obviate this unfavourable influence. This aspect is closely connected with the social aims of every colonisation plan of this kind.

The colonies of the Benevolent Society of Holland may certainly be mentioned as a socio-economic and agricultural experiment of the first rank. In the first half of the igth century the interest of philanthropists, economists and agronomists was focussed upon this project. 
GRONDAANKOPEN MAATSCHAPPIJ VAN WELDADIGHEID I8I9- I840

\begin{tabular}{|c|c|c|c|c|c|c|}
\hline \multirow{2}{*}{ Jaar } & \multicolumn{4}{|c|}{ Aantal aankopen ${ }^{I}$} & \multicolumn{2}{|c|}{ Grond gelegen in de } \\
\hline & totaal & $\begin{array}{l}\text { behuisd } \\
\text { land }\end{array}$ & los land & $\begin{array}{l}\text { aandelen } \\
\text { in marke }{ }^{2}\end{array}$ & gemeente & onverdeelde marke \\
\hline 1819 & 6 & 3 & 2 & $1(+5)$ & $\begin{array}{l}\text { Vledder, } \\
\text { Steenwijkerwold, } \\
\text { Weststellingwerf, } \\
\text { Havelte, } \\
\text { Diever }\end{array}$ & $\begin{array}{l}\text { Vledder, } \\
\text { Doldersum, } \\
\text { Diever en Wateren }\end{array}$ \\
\hline 1820 & 12 & 5 & 6 & I $(+3)$ & $\begin{array}{l}\text { Vledder, } \\
\text { Weststellingwerf, } \\
\text { Diever, } \\
\text { Dwingeloo, } \\
\text { Steenwijkerwold }\end{array}$ & $\begin{array}{l}\text { Doldersum, } \\
\text { Diever en Wateren }\end{array}$ \\
\hline 1821 & 17 & 3 & 8 & $6(+2)$ & $\begin{array}{l}\text { Diever, } \\
\text { Vledder, } \\
\text { Steenwijkerwold, } \\
\text { Weststellingwerf }\end{array}$ & $\begin{array}{l}\text { Diever en Wateren, } \\
\text { Doldersum }\end{array}$ \\
\hline 1822 & 9 & 4 & - & $5(+2)$ & $\begin{array}{l}\text { Vledder, } \\
\text { Diever }\end{array}$ & $\begin{array}{l}\text { Doldersum, } \\
\text { Diever en Wateren }\end{array}$ \\
\hline 1823 & 14 & 2 & 3 & $9(+3)$ & $\begin{array}{l}\text { Diever, } \\
\text { Vledder, } \\
\text { Ooststellingwerf }\end{array}$ & $\begin{array}{l}\text { Diever en Wateren, } \\
\text { Akinge en Ter- } \\
\text { wissche, } \\
\text { Appelsche }\end{array}$ \\
\hline 1824 & 17 & 3 & $\mathbf{I}$ & $x_{3}(+2)$ & $\begin{array}{l}\text { Smilde, } \\
\text { Ooststellingwerf }\end{array}$ & $\begin{array}{l}\text { Appelsche, } \\
\text { Weper }\end{array}$ \\
\hline 1825 & $\mathbf{I}$ & - & $\mathbf{I}$ & - & Weststellingwerf & 2 \\
\hline 1829 & $\mathbf{I}$ & - & $\mathbf{I}$ & - & Vledder & - \\
\hline 1830 & $\mathbf{I}$ & - & $\mathbf{I}$ & - & Vledder & - \\
\hline I 837 & $\mathbf{I}$ & - & $\mathbf{I}$ & - & Vledder & - \\
\hline 1840 & I & - & $\mathbf{I}$ & - & Vledder & - \\
\hline
\end{tabular}

I Incl. ruiltransacties, excl. aankopen ten behoeve van de gestichten te Ommerschans (Ov.) en Veenhuizen (Dr.).

2 In deze kolom betreffen de linker aantallen de aankopen van losse aandelen, de aantallen tussen () hebben betrekking op eerdervermelde aankopen van behuisd of los land, waartoe tevens aandelen behoorden.

Bron: Register van akten van koop etc. der M.v. W. 1819-1846. 
ONROERENDE EIGENDOMMEN MAATSCHAPPIJ VAN WELDADIGHEID $1825 / 33$

\begin{tabular}{lccc}
\hline & \multicolumn{2}{c}{ Ongebouwd } & Gebouwd \\
\cline { 3 - 4 } Gemeente, sectie $\quad$ Aanduiding & $\begin{array}{c}\text { Aantal } \\
\text { percelen }\end{array}$ & $\begin{array}{c}\text { Totale } \\
\text { opp. in } \\
\text { ha }\end{array}$ & $\begin{array}{c}\text { opp. in } \\
\text { ha per } \\
\text { perc. }\end{array}$ \\
\hline
\end{tabular}

Gem. Vledder (1825)

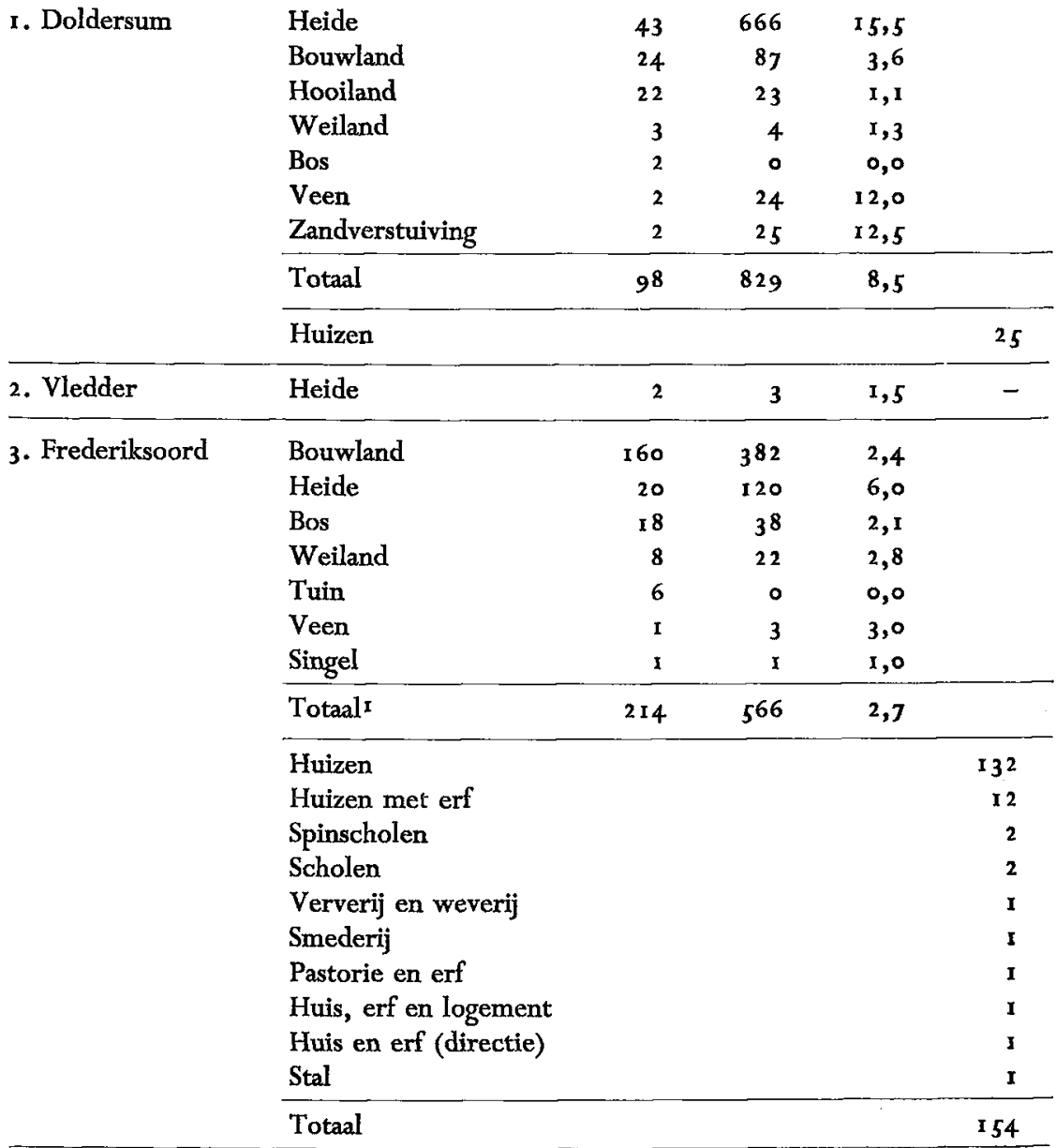

I Excl. 3 afzonderlijk vermelde percelen (1 gracht, 2 allees). 


\begin{tabular}{lcccc}
\hline & \multicolumn{3}{c}{ Ongebouwd } & Gebouwd \\
\cline { 3 - 5 } Gemente, sectie & Aanduiding & $\begin{array}{c}\text { Totale } \\
\text { percelen } \\
\text { opp. in } \\
\text { ha }\end{array}$ & $\begin{array}{c}\text { opp. in } \\
\text { ha per } \\
\text { perc. }\end{array}$ \\
\hline
\end{tabular}

\begin{tabular}{llllll}
$\begin{array}{l}\text { 4. Nijensleek } \\
\text { Oostzijde }\end{array}$ & Weiland & 2 & 5 & 2,5 & - \\
\hline $\begin{array}{l}\text { 5. Nijensleek } \\
\text { Westzijde }\end{array}$ & Heide & I & 20 & 20,0 & - \\
\hline
\end{tabular}

Gem. Diever (1826)

\begin{tabular}{|c|c|c|c|c|c|}
\hline \multirow[t]{10}{*}{ I. Wateren } & Bouwland & $3^{8}$ & 103 & 2,1 & \\
\hline & Weiland & 14 & 12 & 0,9 & \\
\hline & Hooiland & 4 & 14 & 3,7 & \\
\hline & Heide & 3 & 936 & $3 \times 2,0$ & \\
\hline & Hakhout & 2 & 0 & 0,0 & \\
\hline & Tuin & 2 & $\mathbf{I}$ & 0,5 & \\
\hline & Totaal & 63 & 1.066 & 16,9 & \\
\hline & Huis en hof & & & & 4 \\
\hline & Huis of kweekschool & & & & I \\
\hline & Totaal & & & & 5 \\
\hline 2. Kalteren & Weiland & $\mathbf{I}$ & 4 & 4 & - \\
\hline
\end{tabular}

Gem. Steenwijkerwold (1830)

\begin{tabular}{|c|c|c|c|c|c|}
\hline \multirow[t]{4}{*}{ Willemsoord } & $\begin{array}{l}\text { Bouwland } \\
\text { Heide } \\
\text { Tuin }\end{array}$ & $\begin{array}{r}143 \\
8 \\
1\end{array}$ & $\begin{array}{r}380 \\
36 \\
0\end{array}$ & $\begin{array}{l}2,7 \\
4,5 \\
0,0\end{array}$ & \\
\hline & Totaal & 152 & 416 & 2,7 & \\
\hline & $\begin{array}{l}\text { Huis en erf } \\
\text { School en erf } \\
\text { Huis, erf en schuur } \\
\text { Spinzaal, huis en erf }\end{array}$ & & & & $\begin{array}{r}125 \\
1 \\
I \\
I\end{array}$ \\
\hline & Totaal & & & & I 28 \\
\hline \multirow[t]{4}{*}{ 3. Vierde Wijk } & Bouwland & 16 & 47 & 2,9 & \\
\hline & Heide & $\mathbf{I}$ & 3 & 3,0 & \\
\hline & Totaal & 17 & 50 & 2,9 & \\
\hline & Huis en erf & & & & 16 \\
\hline
\end{tabular}




\begin{tabular}{lcccc}
\hline & \multicolumn{3}{c}{ Ongebouwd } & Gebouwd \\
\cline { 3 - 4 } Gemeente, sectie $\quad$ Aanduiding & Aantal & Totale & Gemidd. Aantal \\
percelen & $\begin{array}{c}\text { opp. in } \\
\text { ha }\end{array}$ & $\begin{array}{c}\text { opp. in percelen } \\
\text { ha per } \\
\text { perc. }\end{array}$ \\
\hline
\end{tabular}

4. Eesveensche

Hooilanden

Hooiland

6

9

I, 5

Gem. Smilde (1833)

(één boerenplaats)

\begin{tabular}{|c|c|c|c|}
\hline Weideland & 4 & I & 0,3 \\
\hline Heide & 3 & $2 \mathrm{I}$ & 7,0 \\
\hline Bouwland & 3 & 4 & $\mathrm{x}, 3$ \\
\hline Bos & I & 3 & 3,0 \\
\hline Totaal & II & 29 & 2,6 \\
\hline
\end{tabular}

Gem. Ooststellingwerf (1833)

\begin{tabular}{llrrrr} 
I. Elsloo & Heide & I & 30 & 30,0 & - \\
\hline 2. Appelscha & Heide & 14 & 630 & 45,0 & - \\
\hline 3. Oosterwolde & Bouwland & 10 & 8 & 0,8 \\
(boerenplaats te & Hooiland & 4 & 5 & $x, 3$ \\
Weper) & Heide & 4 & 76 & 19,0 \\
& Weiland & 4 & 3 & 0,8 \\
& Bos & 1 & 0 & 0,0 \\
& Boomgaard & I & 0 & 0,0 & \\
& Tuin & 1 & 0 & 0,0 & \\
\cline { 2 - 7 } & Totaal3 & 25 & 92 & 3,7 & \\
\cline { 2 - 6 } & Huis & & & & I
\end{tabular}

Gem. Weststellingwerf (1833)

I. Noordwolde

\begin{tabular}{lrrrr}
$\begin{array}{l}\text { Bouwland } \\
\text { Heide }\end{array}$ & $4 \mathrm{I}$ & I 10 & 2,7 \\
\\
\hline Totaal 4 & 3 & 4 & 1,7 & \\
\hline Huizen & 44 & 115 & 2,6 & \\
\hline
\end{tabular}

2 Excl. 7 afzonderlijk vermelde percelen (4 percelen weg, 2 percelen vaart, I perceel wijk), belast als heide.

3 Excl. 2 afzonderlijk vermelde percelen (I perceel erf en I perceel water, belast als heide).

4 Excl. enige afzonderlijk vermelde percelen weg en vaart. 


\begin{tabular}{|c|c|c|c|c|c|}
\hline \multirow[b]{2}{*}{ Gemeente, sectie } & \multirow[b]{2}{*}{ Aanduiding } & \multicolumn{3}{|c|}{ Ongebouwd } & \multirow{2}{*}{ 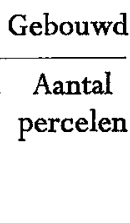 } \\
\hline & & $\begin{array}{c}\text { Aantal } \\
\text { percelen }\end{array}$ & $\begin{array}{l}\text { Totale } \\
\text { opp. in } \\
\text { ha }\end{array}$ & $\begin{array}{l}\text { Gemidd. } \\
\text { opp. in } \\
\text { ha per } \\
\text { perc. }\end{array}$ & \\
\hline \multirow[t]{4}{*}{ 2. Kolonie } & Bouwland & 37 & 108 & 2,9 & \\
\hline & Heide & 4 & IO & 2,5 & \\
\hline & Totaals & $4 I$ & 118 & 2,9 & \\
\hline & Huizen & & & & $3^{8}$ \\
\hline \multirow[t]{3}{*}{ 3. Boyl } & Bouwland & I 3 & 34 & 2,6 & \\
\hline & Heide & 8 & 24 & 3,0 & \\
\hline & Totaal5 & $2 \mathrm{I}$ & $5^{8}$ & 2,8 & - \\
\hline \multirow[t]{6}{*}{ 4. Steggerda } & Heide & 14 & 23 & $x, 6$ & \\
\hline & Bouwland & II & 20 & 1,8 & \\
\hline & Bos & 5 & 6 & 1,2 & \\
\hline & Weiland & 2 & $\circ$ & 0,0 & \\
\hline & Totaal5 & $3^{2}$ & 49 & 1,5 & \\
\hline & Huizen & & & & 5 \\
\hline \multirow[t]{3}{*}{ 5. Finkenga } & Heide & 4 & 6 & 1,5 & \\
\hline & Bos & I & I & 1,0 & \\
\hline & Totaal & 5 & 7 & 1,4 & - \\
\hline
\end{tabular}

5 Excl. enige afzonderlijk vermelde percelen weg en vaart, waaronder de Steggerdersloot in sectie 4 .

Bron: Stukken betreffende de classificatie der gebouwde en ongebouwde eigendommen der Maatschappij ten behoeve van het kadaster en stukken inzake vrijdom van grondbelasting, 1832 en 1833 , oud archief der M.v.W. No. 924, Rijksarchief te Assen. 
Omrekeningsnormen voor de totalisering van de mestproduktie van dieren en mensen:

4 stuks 3 -jarig rundvee $=3$ koeien;

3 vaarzen $=2$ koeien;

2 pinken $=\mathrm{I}$ koe;

3 kalveren $=$ I koe;
2 paarden $=3$ koeien;

Io schapen $=1$ koe;

1000 volwassenen ${ }^{I}=90$ koeien .

Omdat de "stalvoedering op verre na nog niet algemeen" was, vooral niet in 1834 wegens de droogte, rekende Van Konijnenburg slechts op 25 voer per koe per jaar.

\begin{tabular}{|c|c|c|c|c|c|c|c|}
\hline \multirow{2}{*}{ Kolonie } & \multirow{2}{*}{\multicolumn{2}{|c|}{$\begin{array}{l}\text { Mestproduktie } \\
\text { in koeien }\end{array}$}} & \multicolumn{3}{|c|}{ Opp. land in ha } & \multirow{2}{*}{\multicolumn{2}{|c|}{$\begin{array}{l}\text { Mesthoev. in } \\
\text { koeien per ha } \\
\text { bemest land }\end{array}$}} \\
\hline & & & ben & & onbemest & & \\
\hline \multirow[t]{3}{*}{ x } & \multirow{2}{*}{$\begin{array}{l}\text { Koeien } \\
\text { Schapen, kal- } \\
\text { veren, varkens } \\
822 \text { personen = } \\
548 \text { volwasse- } \\
\text { nen }\end{array}$} & \multirow{2}{*}{$\begin{array}{l}198 \\
= \\
20 \\
48\end{array}$} & $\begin{array}{l}\text { Bouwl. } \\
\text { Tuingr. }\end{array}$ & $\begin{array}{l}97,5 \\
16,-\end{array}$ & $\begin{array}{l}\text { Hooil. } \\
\text { Boekweit- } \\
\text { veen }\end{array}$ & 3,5 & \\
\hline & & & \multirow[t]{2}{*}{ Totaal } & \multirow[t]{2}{*}{ I 13,5} & \multirow[t]{2}{*}{ Totaal } & \multirow[t]{2}{*}{$8,-$} & \\
\hline & Totaal & 266 & & & & & 2,3 \\
\hline \multirow[t]{2}{*}{ II } & \multirow[t]{2}{*}{$\begin{array}{l}\text { Totaal } \\
\text { (w.v. aange- } \\
\text { kocht }\end{array}$} & \multirow{2}{*}{$\begin{array}{l}2 \times 9 \\
32)\end{array}$} & $\begin{array}{l}\text { Bouwl. } \\
\text { Tuingr. }\end{array}$ & $\begin{array}{l}68,4 \\
I X, 5\end{array}$ & \multirow[t]{2}{*}{$\begin{array}{l}\text { Boekweit- } \\
\text { veen }\end{array}$} & \multirow[t]{2}{*}{12,6} & \\
\hline & & & Totaal & 79,9 & & & 2,7 \\
\hline \multirow[t]{2}{*}{ III } & \multirow{2}{*}{$\begin{array}{l}\text { Totaal } \\
\text { (w.v. aange- } \\
\text { kocht }\end{array}$} & \multirow{2}{*}{$\begin{array}{l}329 \\
32)\end{array}$} & $\begin{array}{l}\text { Bouwl. } \\
\text { Tuingr. }\end{array}$ & $\begin{array}{r}133,1 \\
19,3\end{array}$ & - & & \\
\hline & & & Totaal & $15^{2}, 4$ & & & 2,2 \\
\hline \multirow[t]{2}{*}{ Wateren } & \multirow[t]{2}{*}{ Totaal } & \multirow[t]{2}{*}{162} & $\begin{array}{l}\text { Bouwl. } \\
\text { Tuingr. }\end{array}$ & $\begin{array}{r}35,4 \\
0,4\end{array}$ & $\begin{array}{l}\text { Hooil. } \\
\text { Boekweit- } \\
\text { veen }\end{array}$ & $\begin{array}{r}74,9 \\
13,5\end{array}$ & \\
\hline & & & Totaal & 35,8 & Totaal & 88,4 & 4,5 \\
\hline
\end{tabular}

I Excl. ambtenaren; de verhouding is afgeleid uit de vermelding, dat ro00 volwassenen per dag 2 voer sekreetmest $=6$ voer rundermest produceerden tegen een koe per jaar 25 voer zuivere mest met een weinig stro.

Bron: Algemene Oogststaat over 1834 . 


\begin{tabular}{|c|c|c|c|c|c|c|c|c|c|c|c|c|}
\hline \multirow{2}{*}{ Gewas } & \multirow{2}{*}{ Kolonie } & \multicolumn{11}{|c|}{ Beteelde oppervlakte in ha in } \\
\hline & & 1831 & 1832 & $1833^{I}$ & 1834 & 1835 & 1836 & 1837 & 1838 & 1839 & 1840 & $184 I$ \\
\hline \multirow[t]{2}{*}{ Rogge } & Gewone koloniën & 203 & I 83 & I $\mathcal{J}_{3}$ & 165 & 160 & 184 & 269 & & 201 & 285 & 205 \\
\hline & Wateren & 17 & 16 & 22 & 25 & 29 & 30 & 25 & & I 8 & 2 I & \\
\hline \multirow[t]{2}{*}{ Gerst, haver ${ }^{2}$} & G.k. & 4 & - & 2 I & - & - & o & & & 3 & $\mathbf{I}$ & \\
\hline & W. & - & 5 & 3 & $\mathbf{I}$ & 3 & 3 & 6 & & 9 & - & \\
\hline \multirow[t]{2}{*}{ Boekweit } & G.k. & 14 & 9 & 17 & I 8 & 20 & 14 & 9 & & 10 & $\mathbf{I}$ & \\
\hline & W. & - & 5 & 6 & I 6 & I 6 & I 6 & 15 & & 10 & 8 & \\
\hline \multirow[t]{2}{*}{ Aardappelen } & G.k. & 98 & 133 & 110 & I 2 I & 96 & $\mathbf{2 7}$ & 148 & & 205 & 183 & \\
\hline & W. & 5 & 5 & 5 & 5 & 5 & 7 & 7 & & 8 & 7 & \\
\hline \multirow[t]{2}{*}{ Vlas } & G.k. & 2 & - & 6 & 6 & 5 & 6 & - & & - & - & \\
\hline & W. & - & - & - & - & - & - & - & & - & - & \\
\hline \multirow[t]{2}{*}{ Zomerkoolzaad } & G.k. & - & - & - & - & - & - & - & & - & - & \\
\hline & W. & - & - & 2 & - & - & - & - & & - & - & \\
\hline Knollen, wortels & $\begin{array}{l}\text { G.k. } \\
\text { W. }\end{array}$ & $\begin{array}{r}16 \\
-\end{array}$ & & & & & & & & & & \\
\hline \multirow[t]{2}{*}{ Gras en klaver } & G.k. & 386 & & 420 & 515 & & & & & I $20^{3}$ & & I73 \\
\hline & W. & 26 & & 102 & & & & & & - & & 70 \\
\hline Brem & $\begin{array}{l}\text { G.k. } \\
\text { W. }\end{array}$ & & & $\begin{array}{r}133 \\
6\end{array}$ & 143 & & & & & & & \\
\hline $\begin{array}{l}\text { Tuinbouw- } \\
\text { gewassen }\end{array}$ & $\begin{array}{l}\text { G.k. } \\
\text { W. }\end{array}$ & & & $\begin{array}{r}54 \\
1\end{array}$ & 55 & & & & & & & \\
\hline
\end{tabular}


Bijlage 5

BOUWPLAN EN VRUCHTOPVOLGINGIN I 854

\begin{tabular}{|c|c|c|c|c|c|c|c|c|}
\hline \multirow{3}{*}{ Voorvrucht } & \multicolumn{8}{|c|}{ Beteelde oppervlakte (ha) } \\
\hline & \multirow{2}{*}{ winterrogge } & \multirow{2}{*}{ aardappelen } & \multirow{2}{*}{ zomergerst } & \multirow{2}{*}{ haver } & \multirow{2}{*}{ boekweit } & \multirow{2}{*}{ tuingrond } & \multicolumn{2}{|c|}{ groenland $\mathbf{I}$} \\
\hline & & & & & & & kw. & bl. \\
\hline \multicolumn{9}{|l|}{ Gewone koloniën } \\
\hline Rogge & 0,7 & - & - & 4,8 & 2,3 & - & - & - \\
\hline Aardappelen & 203,0 & - & 7,0 & - & 0,4 & . & . & . \\
\hline Brem (2-jarig) & 48,8 & $\times 33,1$ & - & - & - & . & - & - \\
\hline Stoppelbrem & - & 63,4 & - & 0,3 & - & - & . & - \\
\hline Kunstweide & 37,9 & 8,8 & - & - & - & . & . & - \\
\hline Bosgrond & - & 0,7 & - & - & - & . & . & . \\
\hline Nieuwe grond & - & 1,0 & - & - & - & - & - & - \\
\hline Totale opp. ${ }^{2}$ & 290,4 & 206,9 & 7,0 & $5, I$ & 2,7 & 23,9 & 284,1 & $\mathbf{2 , 6}$ \\
\hline \multicolumn{9}{|l|}{ Wateren } \\
\hline Rogge & 6,5 & $3,-$ & - & - & 0,8 & . & - & . \\
\hline Aardappelen & 8,4 & - & - & 2,8 & - & - & . & . \\
\hline Brem (2-jarig) & 0,8 & 6,8 & - & - & $\mathrm{I}, \mathbf{8}$ & - & - & - \\
\hline Kunstweide & 3,0 & 1,5 & - & - & - & - & - & - \\
\hline Tot. opp. ${ }^{2}$ & I 8,6 & I I, 3 & - & 2,8 & 2,6 & 0,6 & 17,8 & 35,0 \\
\hline
\end{tabular}

I $\mathrm{kw}=$ kunstweide, bl = blijvend.

2 Exclusief brem.

Bron: Staat der te veld staande Gewassen in den zomer van 1854 . 
Bijlage 6

OPBRENGST VAN ROGGE EN AARDAPPELEN I $831-185^{8}$

\begin{tabular}{|c|c|c|c|c|}
\hline \multirow{2}{*}{ Jaar } & \multicolumn{2}{|l|}{ Rogge } & \multicolumn{2}{|c|}{ Aardappelen } \\
\hline & Gewone koloniën & Wateren & Gewone koloniën & Wateren \\
\hline \multicolumn{5}{|c|}{ (in $\mathrm{mud} / \mathrm{mg}$ ) } \\
\hline $183 \mathrm{I}$ & 7,0 & 5,2 & 136 & 124 \\
\hline $3^{2}$ & 7,8 & I 3,3 & 160 & 175 \\
\hline $33^{I}$ & 12,9 & $\times 9,5$ & 180 & 202 \\
\hline 34 & IO, I & 16,0 & I 33 & 167 \\
\hline 35 & 14,8 & 20,3 & I 58 & 175 \\
\hline 36 & 12,8 & 22,6 & 189 & 2 II \\
\hline 37 & $\times 2,5$ & 19,6 & 140 & 175 \\
\hline $3^{8}$ & I 1,8 & 17,2 & 162 & 161 \\
\hline 39 & 10,9 & 19,4 & 193 & 180 \\
\hline I $84^{\circ}$ & 13,6 & 23,3 & 198 & 204 \\
\hline $4 \mathrm{I}$ & 8,3 & 13,4 & 193 & 126 \\
\hline $4^{2}$ & 10,9 & 13,4 & 162 & ror \\
\hline 43 & 13,0 & $x 7,6$ & 218 & 191 \\
\hline \multicolumn{5}{|c|}{ (vanaf 1844 in $\mathrm{mud} / \mathrm{ha}$ ) } \\
\hline 44 & 11,6 & 16,5 & 263 & 201 \\
\hline 45 & 14,6 & r 7,6 & r 27 & 60 \\
\hline 46 & 7,2 & 7,9 & 140 & 72 \\
\hline 47 & 20,4 & $22, I$ & 172 & I Io \\
\hline $4^{8}$ & 16,9 & 23,6 & $I_{4}$ & 68 \\
\hline 49 & 15,3 & 26,5 & 169 & I 27 \\
\hline $185^{\circ}$ & II, J & I 4,5 & 130 & 90 \\
\hline 51 & I I, 5 & I 7,6 & I 53 & 106 \\
\hline 52 & 10,6 & 18,1 & $130^{2}$ & $89^{2}$ \\
\hline 53 & $\mathrm{II}, \mathrm{I}$ & 14,2 & 99 & 78 \\
\hline 54 & $\mathrm{r}_{\mathcal{T}}, \mathrm{r}$ & 27,3 & $15^{\circ}$ & 123 \\
\hline 55 & 15,0 & 17,9 & 100 & 87 \\
\hline $5^{6}$ & 16,2 & 24,5 & 155 & I I I \\
\hline 57 & 12,5 & 17,5 & 162 & 104 \\
\hline $5^{8}$ & 14,9 & $17, \mathrm{I}$ & 205 & 120 \\
\hline
\end{tabular}

I Vanaf I 833 „zuiver gemeten” maat i.p.v. „voetstoots”。

2 Vanaf 1852 excl. zieke aardappelen.

Bron: oogststaten. 
Bijlage 7

OOGSTRAMING I $856-1859$

\begin{tabular}{|c|c|c|c|c|c|c|c|c|c|c|c|c|}
\hline \multirow{3}{*}{ Gewas } & \multicolumn{12}{|c|}{ Oogstraming in mud/ha voor } \\
\hline & \multicolumn{3}{|c|}{1856} & \multicolumn{3}{|c|}{1857} & \multicolumn{3}{|c|}{$\times 859$} & \multicolumn{3}{|c|}{ gemiddeldr } \\
\hline & Fr. ${ }^{2}$ & W. 3 & $\mathrm{Dr}^{4}$ & Fr. & W. & Dr. & Fr. & W. & Dr. & Fr. & W. & Dr. \\
\hline Aardappelen & 165 & 120 & 200 & I70 & I 20 & 120 & 190 & 100 & 100 & 150 & 150 & 100 \\
\hline Rogge & 16 & 24 & 22 & 13 & 18 & 26 & 12 & $\mathrm{r} 6$ & 18 & 16 & 20 & 22 \\
\hline Haver & 36 & $4 \mathrm{I}$ & 34 & 29 & 19 & 20 & - & - & 20 & 35 & 35 & 34 \\
\hline Boekweit & 15 & 20 & 24 & - & - & 18 & - & - & 28 & 20 & 20 & 22 \\
\hline Gerst & 25 & - & 25 & - & - & - & - & - & - & 30 & 30 & 25 \\
\hline
\end{tabular}

I gemiddelde voor "gewone jaren".

2 Fr. = Frederiksoord $=$ gewone koloniën.

$3 \mathrm{~W}_{\text {. }}=$ Wateren.

4 Dr. = Drentse essen.

Bron: Landbouw-Courant 1856 no. 45,1857 no. 47,1859 no. 46 . 
Bijlage 8

VEESTAPEL IN DE GEWONE KOLONIËN EN TE WATEREN I $827-1858$

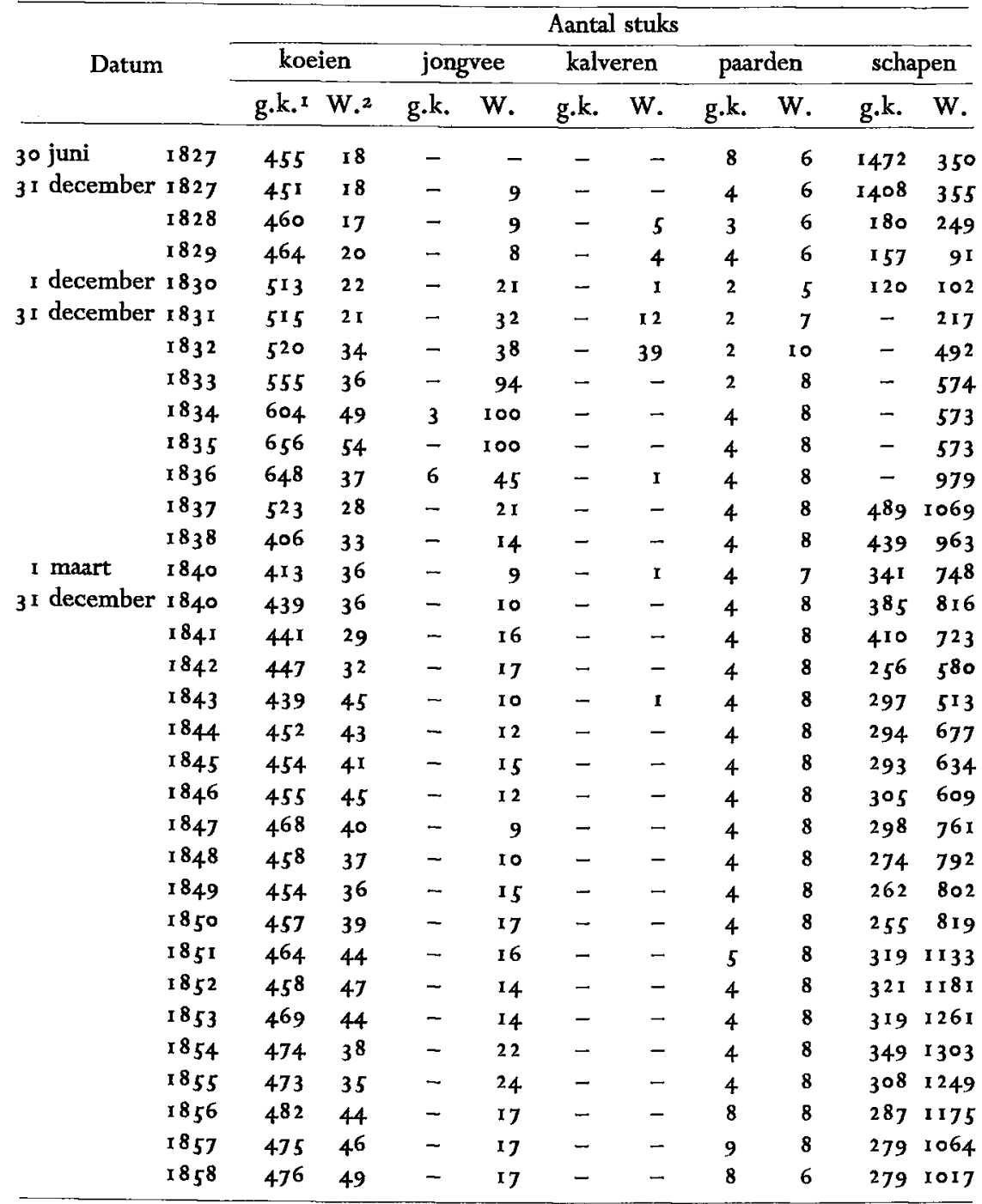

I g.k. = gewone koloniën.

$2 \mathrm{~W}$. = Wateren.

Bronnen: $1827-1839$ Vriend des Vaderlands; $184^{0}-185^{8}$ Algemeene Verslagen. 
VOORZITTERS, SECRETARISSEN EN DIRECTEUREN VAN DE MAATSCHAPPIJ VAN WELDADIGHEID

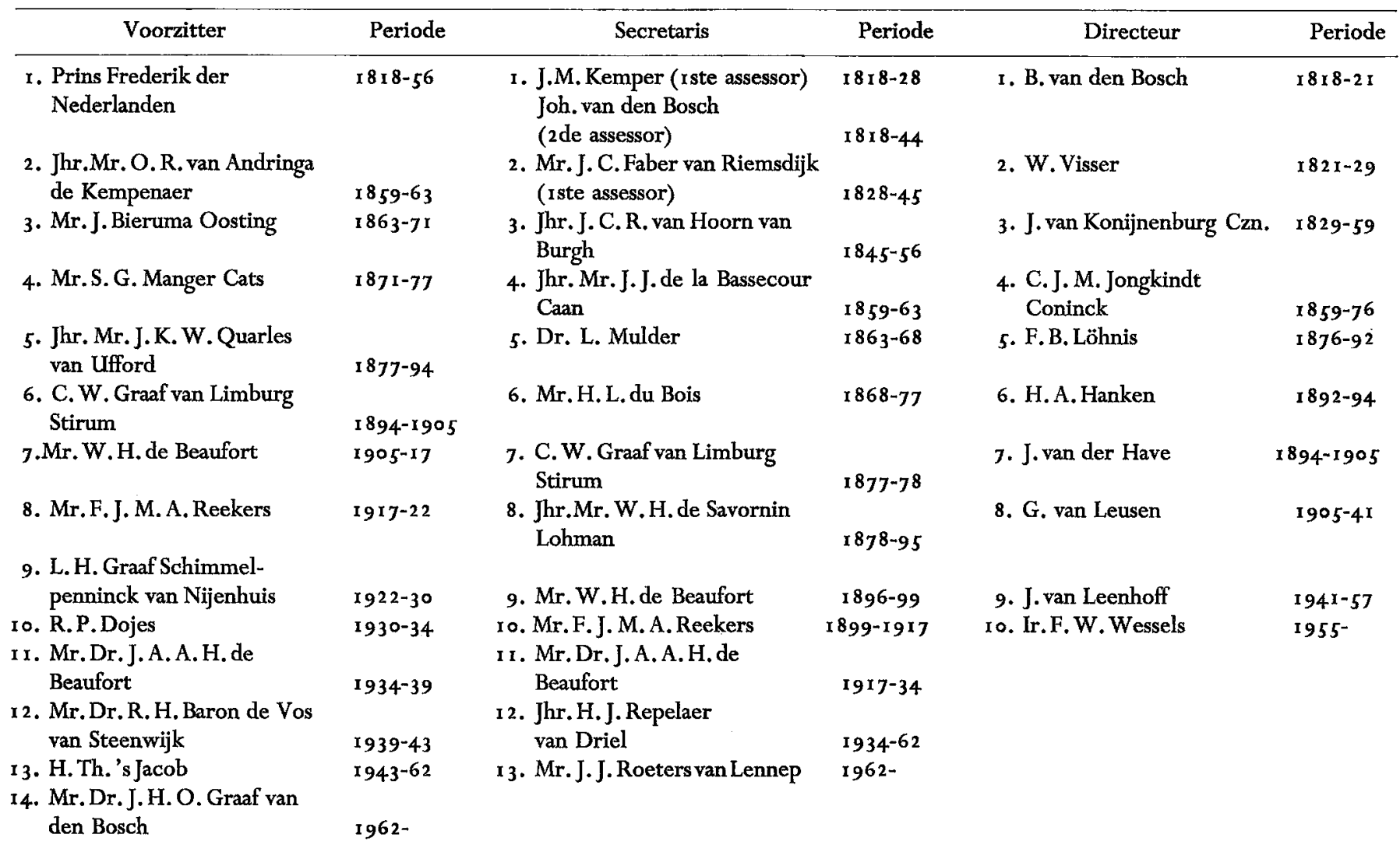




\section{AANTEKENINGEN}

\section{BIJ HOOFDSTUK I - INLEIDING EN PROMBLEEMSTELLING}

I $\mathrm{H}$. Witlox, Schets van de ontwikkeling van welvaart en bedrijvigheid in het Verenigd Koninkrijk der Nederlanden, Benelux 18 I $5-1830$, Nijmegen $\times 956$, blz. 175 .

2 Joh. van den Bosch, Verhandeling over de mogelijkheid, de beste wijze van invoering en de belangrijke voordeelen eener algemeene armeninrigting in het Rijk der Nederlanden, door het vestigen eener landbouwende kolonie in deszelfs Noordelijk gedeelte, Amsterdam 18 I 8, blz. 8 I e.v.

3 J.J. Westendorp Boerma, Johannes van den Bosch als sociaal hervormer; De Maatschappij van Weldadigheid, Groningen 1927, blz. 63 e.v.

4 N.W. Posthumus, Nederlandsche prijsgeschiedenis, I, Leiden 1943 , blz. 3 en 498 .

5 J.C. Ramaer, Het Koninkrijk der Nederlanden ( 18 1 5-193 I), vermeldt in bijl. I, blz. 251 en 253 , als inwonertal in I 8 I 5 voor Purmerend I.496 en voor Amsterdam I 80. I 79 .

6 Van den Bosch, t.a.p., blz. 64 e.v.

7 L.G. J. Verberne, Geschiedenis van Nederland in de jaren $1813-1850$, Utrecht-Antwerpen 1958 , blz. 193 en 194.

8 Van den Bosch, t.a.p., blz. 57 e.v.

9 Hierna, hfdst. $v, \mathbf{r}$.

10 (P. J. Ameshoff), Beschouwing van den tegenwoordigen toestand van Drenthe, in gemeenzame brieven, Amsterdam 18 1 8, blz. 9 en 47 e.v.

II Van den Bosch, t.a.p., blz. 72 e.v.

12 Witlox, t.a.p., blz. 175 en 176.

13 B. H. Slicher van Bath, De agrarische geschiedenis van West-Europa (500-1 $85^{\circ}$ ), Utrecht/Antwerpen 1960, blz. 243 e.v.

14 Zie over de plaggenbemesting: W.A.J. Oosting, De ouderdomsbepaling van onze bouwlanden op het plistoceen en het vraagstuk der ophooging door plaggenbemesting, in : Landbouwkundig Tijdschrift, 52 ste jrg. 1940 , blz. 695 e.v.

${ }_{15}$ J.H.P. van Lier, Tegenwoordige Staat van Drenthe, I795, blz. I3 e.v. en 169.

16 (Ameshoff), t.a.p., blz. Ix e.v. en 118.

$17 \mathrm{~J}$. Linthorst Homan, Van kerspel tot gemeente, Assen 1938, blz. 153.

18 Slicher van Bath, t.a.p., blz. 364 en 365 .

I9 B. v. H. Blink, Geschiedenis van den boerenstand en den landbouw in Nederland, II, Groningen I 904, blz. 4I 2.

20 S. von Grouner, Beschreibung einer Reise durch das Königreich der Niederlande, r, Passau 1826 , blz. 346 en 347 .

2x Blink, t.a.p., blz. $7 x$ e.v.

${ }^{22}$ Verslag gehouden door den Commissaris van Landbouw op de huishoudelijke reize van den Agent van Nationale Economie der Bataafsche Republiek, J. Goldberg, wegens den staat van den landbouw, in: Historia agriculturae, v, Groningen 1959 , blz. 232 e.v.

23 Van Lier, t,a.p., blz. 18.

24 Directie van de Landbouw, De Nederlandsche landbouw in het tijdvak 18 13-19 3 , 's-Gravenhage 1913 , blz. 327 . 
25 I. J. Brugmans, Paardenkracht en mensenmacht; Sociaal-economische geschiedenis van Nederland $1795-1940,196 x$, blz. 55 .

26 Slicher van Bath, t.a.p., blz. 26 I e.v.

27 Westendorp Boerma, t.a.p., blz. 87 ; hierin ook een uitvoerige biografie van Joh. van den Bosch.

28 W.H. de Beaufort, De woeste gronden in Nederland, in: De Gids, 1882 no. 19; Joseph Marshall, Travels through Holland, Flanders, Germany, Denmark, Sweden, Lapland, Russia, the Ukraine and. Poland in the years 1768,1769 and 1770,3 vols., 1772 .

29 Van den Bosch, t.a.p., blz, roo e.v.

30 Idem, blz. 174 e.v.

3i Reglement voor de Maatschappij van Weldadigheid, 's-Gravenhage/Amsterdam 18 I 8.

32 Algemeene Staat van Ontvangsten tot primo April i 8 19.

33 Van den Bosch, De la colonie de Frederiksoord et des moyens de subvenir aux besoins de l'indigence par le défrichement des terres vagues et incultes, Gent I82 I, blz, ro en 11 .

34 A.F. Eilerts de Haan, De Noordnederlandsche landbouwkoloniën, Amsterdam I872, blz. 23.

35 Van den Bosch, De la colonie, t.a.p., blz. 22 e.v.; hierna hfdst. II, I.

${ }^{36}$ Eilerts de Haan, t.a.p., blz. 50.

37 Nadere gegevens in: Eilerts de Haan, t.a.p., en Westendorp Boerma, t.a.p.

38 Algemeen Verslag over $1822 / 23$.

39 Von Grouner, t.a.p., blz. 268 en 364.

40 De Star (eerste tijdschrift der M.v.W.), vil (I 825), blz. 848 en Verslag der subcommissie uit de Commissie van Toevoorzigt, belast met het onderzoek der rekening en verantwoording over 1833 .

4x J.F. Martinet, Het vaderland en het Verenigd Nederland, II, Zaltbommel 1830 , blz. 200.

42 Verslag Subcommissie uit C.v.T. tot onderzoek der rekening en verantwoording over I 836 .

43 J.K. W. Quarles van Ufford, De hervorming der Maatschappij van Weldadigheid, in: De Economist, nov./dec. 1859 en jan. 1860 .

44 Algemeen Verslag over 1843 , resp. 1844 .

45 L.Ph. C. van den Bergh, Gedachten over armoede, overbevolking en kolonisatie, Leiden 1845 , blz, 28 en 38 .

46 O.G. Heldring, Binnen- en buitenlandsche kolonisatie, in betrekking tot de armoede, Amsterdam 1846, blz. 99 .

47 Verslag van het verhandelde op het vijfde Nederlandsch Landhuishoudkundig Congres, gehouden te Leyden, van den roden tot den 14 den Juny $185^{\circ}$, Leiden $x 850$, blz. 37 e.v.

48 W.R. Boer, Denkbeelden over pauperisme en armenverzorging, Amsterdam 1850, blz. 20.

49 Algemeen Verslag over $\times 853$.

so Eilerts de Haan, t.a.p., blz. I87.

5 I In: Landbouw-Courant, I3 de jrg. I 859 , no. 48, blz, 190.

32 Van den Bosch, De la colonie, t.a.p., blz. 83 en 84 .

33 Westendorp Boerma, Generaal Van den Bosch in Drenthe, in: Nieuwe Drentse Volksalmanak, LXXI 1953 (1952), blz. 79 .

54 Linthorst Homan, t.a.p., blz. 179 e.v.

55 Von Grouner, t.a.p., blz. 242 e.v.

56 De Star, (vi) 1824, blz. 788.

57 De Vriend des Vaderlands (tweede tijdschrift der M.v. W.), (III) I 829, blz. 230 e.v.

58 Verslag van de subcommissie uit de Commissie van Toezicht ter inspectie van de koloniën over 1837 .

59 Eilerts de Haan, t.a.p., blz. 34 en 35 .

6o (Wybenga), De Maatschappij van Weldadigheid, overdruk uit: Het Nieuwsblad van Friesland, \pm r930, blz. 2 .

61 Eilerts de Haan, t.a.p., blz. 74 en 75. 
I Hiervoor, blz. 8.

2 x Rijnlandse morgen $(\mathrm{mg})=0,8516 \mathrm{ha} ; 750.000 \mathrm{mg}=638.700 \mathrm{ha}$.

3 Eilerts de Haan, t.a.p., blz. I7.

4 (Ameshoff), t.a.p., blz. 104 e.v.

5 Zoals nader zal blijken, noodzaakte de onverdeelde eigendom van de boermarken echter tot een vrij omslachtige verkrijgingsprocedure ten aanzien van de heidevelden.

6 (Ameshoff), t.a.p., noot bij blz. 107.

7 Linthorst Homan, t.a.p., blz. 76 e.v.

8 Idem, blz. 106 e.v.

- Deze en volgende gegevens zijn ontleend aan het Register, houdende aantekening van de akten van koop, ruiling en verhuur en van overeenkomsten betreffende de eigendommen der Maatschappij, 7 juli 18 I 9-25 april 1846, no, 922 van het oud archief der (rste) Maatschappij van Weldadigheid, berustende in het Rijksarchief te Assen.

ro I mudde bouwland $= \pm 184$ Rijnlandse roeden $=0,26$ ha; 25 mudde $=6,5$ ha.

II I dagmat hooiland $=\frac{2}{3}$ Rijnlandse morgen $=0,57$ ha; 6 dagmat $=3,4$ ha.

12 Gemeente Steenwijkerwold (Overijssel).

$13 \mathrm{I} \mathrm{mg}=600$ roeden; $\mathrm{I}$ roede $=0,14.2$ are; 400 roeden $=0,57$ ha.

14 Gemeente Weststellingwerf (Friesland).

15 Westendorp Boerma, Johannes van den Bosch, t.a.p., blz. I 04.

16 Thans (in 1961) ontvangt de Nederlandse Hervormde Kerk te Vledder in mei en november nog steeds roggepachten van de eigenaren van bepaalde bedrijven en kavels. De pachtsom is uitgedrukt in liters rogge, maar wordt in geld voldaan volgens de geldende roggeprijs.

17 Met deze opbrengst ging de Marke van Steenwijkerwold de bebossing van het niet verkochte gedeelte van het Steenwijkerwoldscheveld financieren (F. B. Löhnis, Verhandeling over de houtcultuur en de bosschen in Drenthe, Haarlem $\times 88_{5}$, blz. 24).

I8 De grondaankopen in dit gebied zijn uitvoerig beschreven in mijn bijdrage De eerste Landbouwschool in Drenthe, in: Nieuwe Drentse Volksalmanak, (80e jaar) 1962, Assen, blz. 30 en 31 .

to Register, t.a.p., akte no. 17 .

${ }^{20}$ Idem, akte no. 44.

2I Aanvankelijk was het de bedoeling in dit gebied twee nieuwe koloniën te stichten, die resp. Frederikaoord en Louisaoord zouden heten (cf. Westendorp Boerma, Generaal Van den Bosch, t.a.p., blz. 66).

22 Register, t.a.p., akte no. 88; De eerste Landbouwschool, t.a.p., blz. 30 en $3 x$.

$23 \mathrm{~J}$. Baert, Het landbouwonderwijs in Nederland vóór 1876, in: Landbouwkundig Tijdschrift no. $691-693$, aug. 1944/dec. 1945 , jan. en febr. 1946 .

24 Register, t.a.p., akte no. $x 16$.

25 De mededeling van Eilerts de Haan (t.a.p., blz. 65), dat in de periode $1827-1843$ geen gronden meer werden aangekocht, is niet juist.

26 Algemeen Verslag over 1858 .

27 Eilerts de Haan, t.a.p., blz. 296.

28 Algemeen Verslag over $1822 / 23$.

29 Stukken betreffende de classificatie der gebouwde en ongebouwde eigendommen der Mij. ten behoeve van het kadaster en stukken in zake vrijdom van grondbelasting, 1832 en $\times 833$, no. 924 van het oud archief der (rste) M. . W., berustende in het Rijksarchief te Assen.

30 J.van Konijnenburg Czn., De toestand der vrije koloniën en het instituut te Wateren bij de afscheiding der gestichten van de goederen, Meppel I 859 , blz. 4 .

3r Linthorst Homan, t.a.p., blz. 9.

32 Naar de kaart van Brauns; Provinciale Planologische Dienst van Drenthe, Beschrijving van de gemeente Vledder, Assen 1955, blz. 5.

33 Bron: Directie van de Landbouw.

34 Bron: Centraal Bureau voor de Statistiek, Bodemstatistiek 1954. 
35 Linthorst Homan, t.a.p., blz. 179.

36 Hiervoor, blz. 8 .

37 Van den Bosch, Verhandeling, t.a.p., blz. 2 1 0 e.v.

38 Over de cultuur van brem als groenbemesting meer in hfdst. vI, 2 .

39 Westendorp Boerma, Johannes van den Bosch, t.a.p., blz. 167 .

40 Von Grouner, t.a.p., blz. 278 e.v.

41 I centenaar was waarschijnlijk gelijk aan Ioo halve ponden.

42 Von Grouner, t.a.p., blz. 282 en 283.

43 Van den Bosch, De la colonie, blz. 37 e.v.

44 I schepel $= \pm \mathrm{I} 2 \frac{1}{2} 1$.

45 Van den Bosch, De la colonie, t.a.p., blz. 40 e.v.

46 De Star (v) I 823 , blz. 926 e.v.; Zie over de studeerkamergeleerde J.Kops: J. Baert, Jan Kops, Pionier van Hollands landbouw, 1943 .

47 Algemeen Verslag over $1822 / 23$.

48 De Star, (VI) I 824, blz. 5 Io.

49 Westendorp Boerma, Johannes van den Bosch, t.a.p., blz. 165 .

so Van Konijnenburg, t.a.p., blz. I7.

5 I Eilerts de Haan, t.a.p., blz. 292.

52 C. J. M. Jongkindt Coninck, Beschouwingen over den landbouw in de koloniën der Maatschappij van Weldadigheid, in: De Nieuwe Boerengoudmijn, (2) I 865 (no. r I), blz. 16 r e.v. Jongkindt Coninck was vóbr 1859 adjunct-directeur van de Landhuishoudkundige School te Groningen en Haren en werd in 1876 de eerste directeur van de toen opgerichte Rijkslandbouwschool te Wageningen.

53 J.van der Have, Kort overzicht van de geschiedenis der Maatschappij van Weldadigheid, I904, blz, 9 .

54 Zie b.v. J.Z.ten Rodengate Marissen, Grondverbetering, deel 11, Ontginning van veen- en heidegronden, Groningen-Batavia 1949, blz. 127 e.v.

55 Algemeen Verslag over $1823 / 24$.

56 Van Konijnenburg, Berigt omtrent de ontginning van een klein stuk heidegrond in de gemeente Vledder, in: De Vriend des Vaderlands, (vIr) I 833 , blz. 8 Io e.v.

57 De Star, (vi) I 824 , blz. 789 e.v.

58 Vriend, (VII) I 833 , blz. 80 .

59 Algemeen Verslag over 1828.

60 Westendorp Boerma, Generaal Van den Bosch, t.a.p., blz. 75.

6I Van den Bosch, Vérhandeling over de inrichting van den landbouw, den arbeid en de administratie, 1836 , no. 1648 van het oud archief der (Iste) M.v.W., te Assen.

62 Algemeen Verslag over 1836.

63 Vriend, (XI) 1837 , blz. 917 : Kolonie-Berigten over December 1837.

64 Idem, (XIV) I840, blz. 263 : Kolonie-Berigten over de maand Maart 1840.

65 Algemeen Verslag over 1840.

66 Idem over I 844 .

67 Idem over I 837 .

68 Idem over I 849.

69 B.D. G. Wardenburg, Kunnen de nadeelen, met welke eene ontbinding der Maatschappij van Weldadigheid alle bij die instelling belanghebbenden bedreigt, niet afgewend worden? Amsterdam 1857 , blz. 16.

70 Algemeen Verslag over $1823 / 24$.

71 Afgeleid uit: De toestand der Maatschappij van Weldadigheid in 1860, door H.H. Commissarissen, 's-Gravenhage $186 \mathrm{I}$, blz. 28 en 30. Deze opgaven wijken af van die van Van Konijnenburg, aangehaald aan het einde van $\S \mathrm{I}$. 
I Beschreven in het artikel : De excursie naar de Maatschappij van Weldadigheid te Frederiksoord op 8 en 9 juni $x$ 899, in: Orgaan der Vereeniging van Oudleerlingen der Rijkslandbouwschool, Tiel I 899 , blz. I 5 en 16 .

2 Westendorp Boerma, Johannes van den Bosch, t.a.p., blz. 165 en 166.

3 Jongkindt Coninck, t.a.p.

4 Von Grouner, t.a.p., blz. 295 e.v.

5 Idem, blz, 298 en 299.

6 Algemeen Verslag over 1855 .

7 Idem over I 841 .

8 Idem over 1842 .

9 Hiervoor, blz. 3 .

roVan den Bosch, Verhandeling over de mogelijkheid, t.a.p., blz. 55 en $5^{6 .}$

II Idem, blz. I42 e.v.

t2 Bijlage 2 bij Van den Bosch, De la colonie, t.a.p., blz. 6x e.v.

13 Idem, blz. 93.

I4 Idem, blz. 12 e.v, en 37.

Is Vriend, (I) 1827 , blz. 931 .

I6 Algemeen Verslag over $182 \mathrm{j} / 28$.

17 Hiervoor, bla. 37.

I8 M.v. W., Tets over de inrigtingen der Maatschappij van Weldadigheid in het Koningrijk der Nederlanden, 1840 , blz. 8 e.v.

ro Staatscommissie I 84. I, Rapport van de Staatscommissie, ingesteld op 26 oktober I841, blz. 32 e.r.

20 De beide overige leden waren: Jhr. Mr. J. K. W. Quarles van Ufford, advocaat bij de Hoge Raad te 's-Gravenhage, en D. Viehoff, predikant bij de Lutherse Gemeente te Monnikendam, later te Utrecht. Omdat de critische inhoud van het rapport de Permanente Commissie niet welgevallig was, besloot zij niet tot publikatie over te gaan in tegenstelling tot de normale gang van zaken. Staring en Quarles van Ufford hebben het rapport daarop zelf en onder hun eigen verantwoordelijkheid gepubliceerd. Het vroegere privé-exemplaar van Quarles van Ufford, thans berustend in het archief van de M.v.W. te Frederiksoord, is voorzien van talrijke interessante aantekeningen van zijn hand.

2I W.C.H. Staring en J. K. W. Quarles van Ufford, De koloniën der Maatschappij van Weldadigheid in 1846 , Arnhem 1847 , blz, 64 en 65 .

22 Van Konijnenburg, De toestand, t.a.p., blz. 3.

23 Von Grouner, t.a.p., blz. 254 en 255.

24 Hiervoor, 2, laatste alinea.

25 Van den Bosch, De la colonie, t.a.p., blz. 37.

26 M.v.W., Iets over de inrigtingen, t.a.p., I 840, blz. 8 e.v.

27 Staring en Quarles van Ufford, t.a.p., blz. 22 en 23.

28 Van Konijnenburg, De toestand, t.a.p., blz. 32 e.v.

29 Algemeen Verslag over I848.

30 Jongkindt Coninck, t.a.p.

3I Von Grouner, t.a.p., bla. 289 e.v.

32 Idem, blz. 291 e.v.

33 Verslag van de subcommissie uit de Commissie van Toezicht tot onderzoek van de rekening en verantwoording over 1833 .

34 Hiervoor, blz. 25.

35 Algemeen Verslag over 1844 .

36 Idem over 1846.

37 Staring en Quarles van Ufford, t.a.p., blz. I 2. 
38 Linthorst Homan, t.a.p., blz. 208.

39 Von Grouner, t.a.p., blz. 295 e.v.

40 Westendorp Boerma, Johannes van den Bosch, t.a.p., bla. I 13.

41 Berigten uit de Koloniën over Augustus 1832 , in: Vriend, (VI) I 832 , blz. 603 .

42 Idem over November 1833 , in: Vriend, (vII) 1833 , blz. 891 en 892.

43 Idem over November 1836 , in: Vriend, $(x) 1836$, blz. 853.

44 Staring en Quarles van Ufford, t.a.p., blz. 12 en 13 .

43 Hiervoor, blz. 42.

46 Van den Bosch, Verhandeling over de mogelijkheid, t.a.p.

47 Idem, blz. 175 e.v.

48 Idem, blz. 206 e.v.

49 Idem, blz. 222.

50 Quarles van Ufford, t.a.p.

5x Eilerts de Haan, t.a.p., blz. 32.

52 Westendorp Boerma, Johannes van den Bosch, t.a.p., blz, 136 e.v.

53 Van den Bosch, De la colonie, t.a.p., blz. 24 e.v.

54 Idem, blz. 55 e.v. (bijlage I: Reglement voor de kolonie Frederiksoord, en voorwaarden, waaraan de gezinshoofden zichzelf en hun gezinsleden verplichten zich te onderwerpen, door het stellen van hun handtekening, bij aankomst in de koloniën).

55 Von Grouner, t.a.p., noot bij blz. 360.

56 Westendorp Boerma, Johannes van den Bosch, t.a.p., blz. i 71 .

57 B.v. De Star, (vr) 1824 , blz. 5 ×4 e.v.; noot 53 hiervoor.

58 Opgesteld door een subcommissie uit de Commissie van Toezicht; het lid Jan Kops onderschreef dit voorstel niet; in: De Star, (v) I 823 , blz. 960 en 961.

59 Het onderwijs en de geneeskundige verzorging werden sedert de stichting van de koloniën bekostigd door de Maatschappij, die de nodige onderwijzers en een arts in dienst had. Op het loon van de kolonisten-arbeiders werd een bedrag ingehouden voor de geneeskundige dienst, zodat men kan stellen, dat bijna 150 jaar geleden hier reeds sprake was van een verplicht ziekenfonds!

60 M.v. W., Tets over de inrigtingen, t.a.p., blz. 29.

6x Over de teelt van brem als groenbemestingsgewas nader in hoofdstuk Iv, 2 .

62 F.W.Fabius, De Maatschappij van Weldadigheid, in hare werking, strekking en geldelijken toestand, Amsterdam $184 \mathrm{r}, \mathrm{blz} .6 \mathrm{r}$.

63 Zie het volledige citaat op blz. 46 en 47.

64 H. G. Willink, The Dutch home labour colonies, their origin and development, London 1889 , blz. 15 en 16 ; J. M'Neill, Free and pauper colonies in Holland, in: Eigth annual report van de Board of Supervision for the Relief of the Poor (Scotland), Westminster i 853 .

65 Eilerts de Haan, t.a.p., blz. 189.

66 W.J.van Welderen Rengers, Overzicht van het beheer der Maatschappij van Weldadigheid na de reorganisatie $\operatorname{van} 1859$, 1893 , blz. 5 en 6 .

67 Van Konijnenburg, De toestand, t.a.p., blz. 36 .

68 Von Grouner, t.a.p., blz. 300 e.v.

69 (Wardenburg), Vlugtige waarnemingen omtrent de ondernemingen der Maatschappij van Weldadigheid in de noordelijke provinciën van het Koninkrijk der Nederlanden, Koevorden 1828, blz. 23 e.v.

70 Vriend, (Ir) I 828, blz. 3 10 e.v. en blz. 368 e.v.

71 Westendorp Boerma, Johannes van den Bosch, t.a.p., blz. 135 .

72 Staring en Quarles van Ufford, t.a.p., blz. 54.

73 Van Konijnenburg, De toestand, t.a.p., blz. 5 e.v.

74 (Wardenburg), Vlugtige waarnemingen, t.a.p., blz. 89 e.v. De potstal was destijds het normale staltype.

75 Eilerts de Haan, t.a.p., blz. 2 ro e.v.

76 Staring en Quarles van Ufford, t.a.p., blz. 93 en 94. 
I Deze en volgende bijzonderheden zijn ontleend aan Westendorp Boerma, Johannes van den Bosch, t.a.p., blz. 164 en 165 . Zie over Thaer: W.Simons, Albrecht Thaer, nach amtlichen und privaten Dokumenten aus einer grossen Zeit, Berlijn I929; over Sinclair: R. Mitchison, Agricultural Sir John, The life of Sir John Sinclair of Ulbster, 1754-1835, Londen I962 ; over Cobbett: William Reitzel (ed.), The autobiography of William Cobbett, The progress of a plough-boy to a seat in parliament, Londen 1947 .

2 Van den Bosch, Verhandeling over de mogelijkheid, t.a.p., blz. xi 7 e.v.; hiervóór blz. 8.

$3 \S 2$ van dit hoofdstuk.

4 Van den Bosch, De la colonie, t.a.p., blz. 37 e.v.

3 Idem, Préface door De Keverberg, blz, xxm e.v.

6 Eilerts de Haan, t.a.p., blz. 59.

7 Westendorp Boerma, Generaal Van den Bosch, t.a.p., blz. 71 .

8 Brief d.d. 2 2-8-3 I van Van Konijnenburg aan de Permanente Commissie, bijlage bij de oogststaten, I 83 I-1 857 , no. I 14I-1 143 van het oud archief der Maatschappij, berustend in het Rijksarchief te Assen.

9 Algemene oogststaat over 1834 .

Io Geschreven door Van den Bosch in 1836 ; no. 1648 van het oud archief der Maatschappij, berustend in het Rijksarchief te Assen.

II Westendorp Boerma, Johannes van den Bosch, t.a.p., blz. 189.

I2 In feite waren de hooiaankopen door de Maatschappij in Friesland en bij Kuinre in de kop van Overijssel reeds lang regel geworden.

I 3 Staatscommissie i 841, t,a.p., blz. 32 e.v.

14 Staat van de opbrengst van het zuivel in 1842 .

15 Staring en Quarles van Ufford, t.a.p., blz. I 7 en 18.

16 Algemeen Verslag over 1848 .

17 Staat der te veld staande Gewassen in den zomer van 1854 .

18 Idem 1857 .

19 Wardenburg, Kunnen de nadeelen, t.a.p., blz. $x_{3}$ e.v.

20 Uitvoerig beschreven door Eilerts de Haan, t.a.p., blz. I 45 e.v.

21 Verslag van de subcommissie uit de Commissie van Toezicht over het onderzoek van de algemene toestand der koloniën in $\times 837$.

${ }^{22}$ Idem in 1838 .

23 Oogst-staat van Tuinvruchten en Zaden in 1840.

24. Van Welderen Rengers, t.a.p., blz. 5 en 6.

25 Vriend, (vir) I 833 , blz. 80 .

26 Staat van de opbrengst van het zuivel in 1842 , resp. Staat dex te veld staande Gewassen in den zomer $\operatorname{van} 1854$.

27 Idem 1857 .

${ }^{28}$ Staat van den oogst der Tuinvruchten en Zaden in $r 846$.

29 Idem 1851 .

30 De Star, (VII) I826, blz. I 99 .

31 Van Konijnenburg, De toestand, t.a.p., blz. 15 .

32 Van den Bosch, Verhandeling over de mogelijkheid, t.a.p., blz. 149 e.v.

33 J.F. Serrurier, Boerengoudmijn, Amsterdam I 807, blz. 269.

34 I. Thys, Memorie of vertoog over het uytgeven en tot culture brengen der vage en inculte gronden in de Meyerye van 's-Hertogen-Bosch, blz. $40 \mathrm{r}$ e.v.

35 Van den Bosch, De la colonie, t.a.p., blz. I3.

36 Idem, blz. 4I.

37 Von Grouner, t.a.p., blz. 283 e.v.

38 Idem, blz. 323 e.v.

39 Westendorp Boerma, Johannes van den Bosch, t.a.p., blz. 167 , noot ${ }^{2}$, maakt melding van het 
plan van de stichter gemetselde gierbakken te laten maken. Zijn opmerking, dat deze waarschijnlijk achterwege zijn gebleven wegens te hoge kosten, wordt door Von Grouner's beschrijving bevestigd.

40 Von Grouner, t.a.p., blz. 337.

4x Idem, blz. 340 en $34 \mathrm{I}$.

42 B.v. Westendorp Boerma, Johannes van den Bosch, t.a.p., blz. 167 .

43 Onderdeel van het verslag over de staat der koloniën in 1823 door een subcommissie uit de Commissie van Toezicht, opgenomen in De Star, (v) 1823 , blz. 926 e.v.

44 De Star, (vi) 1824, blz. 5 I 3.

45 Vriend, (I) 1827 , blz. 908 e. .

46 Idem, (II) I 828 , blz. 802 .

47 Vriend, (I) 1827 , blz. 664 en 665 .

48 P. Lindemans, Geschiedenis van de landbouw in België, Antwerpen 1952, 1, blz. 435 en 436.

49 (Wardenburg), Vlugtige waarnemingen, t.a.p., blz. I $_{3}$ e.v.

so Verzameling van reglementaire en organieke wetten en verordeningen der Maatschappij van Weldadigheid, Amsterdam r 820 , blz. 85.

5I Huishoudelijke bepalingen voor de vrije koloniën, Amsterdam 1822 .

52 Beoordeeling en wederlegging van de vlugtige warnemingen, in: Vriend, (II) x 828, blz. 368 e.v.

53 Vriend, (III) 1829 , blz. 844.

54 Idem, (Iv) 1830 , blz. $3 \times 3$.

55 Hiervoor, blz, 68 e.v.

56 Staat van den Aardappel-Oogst in I 831 , resp. 1832 .

37 Staat van de te velde staande gewassen in 1833 .

58 Staat van den Aardappel-Oogst in 1833 .

59 Eilerts de Haan, t.a.p., blz. 379, en rapport van de subcommissie uit de Commissie van Toezicht tot onderzoek van de staat der koloniën en gestichten d,d. I 7 oktober 1834 .

60 J. M.L. Otten en G. Veenstra, Bemestingsleer, Groningen-Batavia 1 943, blz. 52 e.v.

61 Hiervoor, blz. 69 e.v.

62 Van den Bosch, Verhandeling over de inrigting, t.a.p., iste afdeling.

63 Algemeene Oogst-Staat van $\times 837$.

64 Verslag betrekkelijk het geldelijk beheer der M.v. W. over I $_{37}$ of het twintigste Dienstjaar, namens de Commissie van Weldadigheid aan die van Toezigt.

65 Algemeene Oogst-Staat van 1838 .

66 Staat van den Aardappel-Oogst in 1839.

67 Algemeene Oogst-Staat van I 839.

68 Vriend, (XIV) I 840, blz. 30x e.v.

69 M.v. W., Iets over de inrigtingen, t.a.p., blz. 8 e.v.

70 Staat van den Aardappel-Oogst in 1840.

7x Staat van den Rogge-Oogst in 1840.

72 Staat van den Boekweit-Oogst in 1840 .

73 Vriend, (xIv) I 840, Kolonie-Berigten over Augustus 1840.

74 Staat van den Rogge-Oogst in 1842.

75 Staat van den Aardappel-Oogst in 1842 .

76 Oogst-Staat van de Groene erwten en Duivenboonen in 1843 .

77 Staat van den oogst der Tuinvruchten en Zaden in 1843 .

78 Staat van den Aardappel-Oogst in 1844.

79 Algemeen Verslag over 1844 ; volgens Van der Poel in Historia Agriculturae, r, GroningenDjakarta 1953, blz. 130 , noot ${ }^{\mathrm{t}}$, is poortaarde ${ }_{2} .$. . de stoffe, die uit de sekreeten van tijd tot tijd geruimd wordt, en, op staalen bij een gebragt, eene wijl tijds voor de opene lucht is blootgesteld geweest."

80 Staat van den Rogge-Oogst in 1845; in het Algemeen Verslag over 1845 zijn wel de resultaten van de proeven vermeld, maar geen conclusies. 
81 Staring en Quarles van Ufford, t.a.p., blz. I6 e.v.

82 Staat van den Aardappel-Oogst in $\times 847$.

83 Staat van den Oogst der Tuinvruchten en Zaden in 1847.

84 Idem $x 849$.

85 Idem 1851 .

86 Staat van den Rogge-Oogst in 1851 volgens de tauxatie.

87 Idem in 1856

88 Hiervóór, blz. $9^{2}$.

89 Stat van den Rogge-Oogst in 1857 volgens de tauxatie.

90 B.D.G. Wardenburg, Verhandeling over de beste wijze, op welke, door de ontginning eene nieuwe mildvloeyende bron van volksbestaan en welvaart in het Koninkrijk der Nederlanden kan geopend worden, Groningen 1829 , blz. I 97 e.v.

9I Aangehaald door Schwerz, Anleitung zur Kentniss der Belgischen Landwirtschaft; vlgs. Lindemans, t.a.p., blz. 436, was De Coster in het laatst der 18 de eeuw de grote propagandist van de kunstmatige bremweiden.

92 In: de Landbouw-Courant, $x$ xde jrg. 1857 , no. 43.

93 Wardenburg, Kunnen de nadeelen, t.a.p., blz. 5 e.v.

94 Van Konijnenburg, De toestand, t.a.p., blz. 13 e.v.

95 Eilerts de Haan, t.a.p., blz. I 43.

96 Eilerts de Haan, Is de Maatschappij van Weldadigheid eene instelling van armenzorg?, in: De Gids, december 1879 .

97 Jongkindt Coninck, t.a.p.

98 Eilerts de Haan, De Noordnederlandsche landbouwkoloniën, t.a.p., blz. 7o.

99 Van den Bosch, Verhandeling over de mogelijkheid, t.a.p., blz. 2 Io e.v.

s00 Idem, De la colonie, t.a.p., blz. 36 e.v., hiervóór fig. 3, blz. $5 x$.

rox Slicher van Bath, t.a.p., blz. 275.

I02 Von Grouner, t.a.p., blz. 342 e.v.

ro3 Algemeen Verslag over I 822/23.

104 De Star, (v) I 823 , blz. 926 e.v.

ros Vriend, (I) 1827 , blz. 529 en $53^{\circ}$; de mangels of voederbieten zijn afkomstig uit Duitsland, de turnips of voederknollen uit Engeland.

106 Vriend, (II) I 828, blz, 400.

107 Westendorp Boerma, Johannes van den Bosch, t.a.p., blz. I 78 en 179.

108 Van den Bosch, Over de inrigting, t.a.p.

109 M.v.W., Iets over de inrigtingen, t.a.p., blz. 8 e.v.

110 Staat van den Hooi-Oogst in 1845 .

III Staring en Quarles van Ufford, t.a.p., blz. 19 e.v.

$x_{2}$ Opbrengstcijfers komen voor in het volgende gedeelte (c) van deze paragraaf.

113 Staat van den Hooi-Oogst in I 848 .

x14 Berigten omtrent de M.v.W., inzonderheid wegens den staat van hare koloniën, 25 oktober 1854 .

II5 Van Konijnenburg, De toestand, t.a.p., blz. 32 e.v.

I16 Algemeen Verslag over $1822 / 23$.

II Het betreft hier schepels van 40 oude ponden.

1 mud $=66$ Ned. p. $=$ 7o kg rogge en consumptie-aardappelen.

I Ned. p. $=2$ oude p.

I18 Landbouw-Economisch Instituut en Centraal Bureau voor de Statistiek, Landbouwcijfers 1961, blz. 87.

I19 Vriend (I), I827, blz. 838 .

120 (Wardenburg), Vlugtige waarnemingen, blz. 55 e.v. en 92 e.v.

I21 Vriend (II), r828, blz. 88 1 en 958, (III), 1829, blz. 688 e.v., 844, 921 en 922 , Algemeen Verslag over 1829 .

I22 Westendorp Boerma, Generaal Van den Bosch, blz. 72 e.v. 
123 Wardenburg, Verhandeling over de ontginning, t.a.p., blz; 97, noot 8.

124 Van Konijnenburg, De toestand, t.a.p., blz. 17 .

125 Vriend (v), $x 83 \mathrm{I}$, blz. 617 e.v.

126 Idem, blz. 854 .

127 Staat van den Aardappel-oogst in 1832 .

128 Staat van den Vlas- en Lijnzaadoogst in 1832 .

I29 Staat van den Rogge-oogst in 1832 .

r30 Idem 1833 .

I3I Vriend (vo), 1833, blz. $99 \mathrm{x}$.

132 Vriend (vix), 1834 , blz, 626 en 627.

133 Staat van den Rogge-oogst in 1836 .

I34 Idem 1837 .

133 Staat van den Aardappeloogst in 1837 .

x 36 Westendorp Boerma, Johannes van den Bosch, t.a.p., blz. I 87 .

$x_{37}$ Staat van den Rogge-oogst in $1_{83} 8$.

r 38 Vriend (Xim), r 839 , bla. 233 en 234.

I39 Staat van den Aardappel-oogst in 1838 , resp. 1839 en 1840.

I40 Staat van den Rogge-oogst in 1840 .

I41 Staat van den Haver-oogst in 1843 .

I42 Staat van den Rogge-oogst in 1843 .

I43 Staat van den Aardappel-oogst in 1843 .

144 Algemeene Oogststat van 1843; citat hiervoor, blz. 96 e.v.

I45 Algemeene Oogststaat van 1844 .

446 Staat van den Rogge-Oogst in 1845 .

147 Staat van den Aardappel-Oogst in 1845 , geschreven op 3 december 1845 .

48 De genoemde periode beslaat 4 maanden.

I49 De hitte kostte zelfs hier en daar mensenlevens (Algemeene Oogststaat van I 845).

130 Financieel Verslag over I 845 .

151 Staat van den Aardappel-Oogst in 1846 .

r52 Staat van den Rogge-Oogst in 1846 volgens de tauxatie.

x53 Financieel Verslag over 1846.

I54. Idem over 1847 .

I55 Staat van den Rogge-Oogst in 1847 volgens de tauxatie.

156 Staat van den Aardappel-oogst in 1847 .

${ }_{157}$ Eilerts de Haan, t.a.p., blz. 147 .

158 Staat van den Aardappel-Oogst in 1848 .

159 Eilerts de Haan, t.a.p., blz. 148 e.v.

I60 Hiervóór, blz. 72, 73, 1 I 5 en I 16 .

161 Staat van den Boekweit-Oogst in 1848 .

I62 Staat van den Rogge-Oogst in 1849 volgens de tauxatie.

163 Staat van den Aardappel-Oogst in $185^{\circ}$.

I64 Staat van den Rogge-Oogst in 1851 volgens de tauxatie (resp. in 1852 ).

165 Staat van den Aardappel-Oogst in 1852 , resp. 1853 .

I66 Stat van den Haver-Oogst in 1853 .

I67 Eilerts de Haan, t.a.p., blz, 149.

168 Staat der te veld staande Gewassen in den zomer van 1854.

I69 Staat van den Aardappel-Oogst in 1855 , resp. 1856 .

170 Staat der te veld staande Gewassen in den Zomer van 1857.

171 Staat van den Rogge-Oogst in $\times 857$ volgens de tauxatie.

I72 Landbouw-Courant, rode jrg. (1856) no. 45 , I Ide jrg. (1857) no. 47 en r 3 de jrg. (1859) no. 46.

173 C. A. Bergsma, De aardappel-epidemie in Nederland in den jare 1845,1845 , blz. 32 .

I74 W. C. van der Meer en P. A. van den Ban, Bijzondere plantenteelt, I953, blz. 142. 
175 Hiervoor hoofdstuk Iv, I, resp. 2, sub b.

176 Hiervóór, blz. 66 en 79.

177 Van den Bosch, De la colonie, t.a.p., blz. 24 e.v.

178 Von Grouner, t.a.p., blz. 348 e.v.

179 De Star, (v) I 823 , blz. 926 e.v.

180 Westendorp Boerma, Johannes van den Bosch, t.a.p., blz. I 36, noot 3 .

I8I Vriend, (WI) I 829 , blz. 688 e.v.

182 Vriend, (Iv) 1830 , blz. $3 \mathrm{r}_{3}$.

183 Vriend, (v) 1831 , blz. 772 e.v.

I84 Staat van den Hooioogst in 1832 .

I85 Vriend, (vi) $\times 832$, blz. 897.

I86 Wardenburg, Verhandeling, t.a.p., blz. 9 i e.v.

I87 Vriend, (VIr) 1833 , blz. 76 , Berigten over Januarij 1833 .

188 Deze aantallen betroffen alle koloniën incl. de gestichten. Staat van opbrengst van vee en wol over 1833 .

I89 Algemeen Verslag over 1834 .

r9o Vriend, (virr) I834, blz. 420.

r9r Idem, blz. 85 en 86 .

192 Staat van den Hooi-oogst in 1834 .

193 Algemeene Oogststaat over 1834 .

194 Staat van de Opbrengst in Vee en Wol in 1835 .

195 Hiervóór blz. 70 en 7 I.

196 Staat van de Opbrengst in Vee en Wol in 1836.

197 Staat van den Hooi-oogst in 1836.

r 98 Staat van de Opbrengst van aangefokt en Slagtvee en van Wol in 1837 .

199 Verslag betrekkelijk het geldelijk beheer der M.v.W. over 1837 of het twintigste Dienstjaar, namens de Commissie van Weldadigheid aan die van Toevoorzigt.

200 Over Numan: H.A.Zwijnenberg, Alexander Numan, in het bijzonder zijn invloed op de Nederlandsche schapenfokkerij, diss. Utrecht 1925 .

201 Staat van den Hooi-oogst in 1838 .

202 Verslag van de Subcommissie uit de Commissie van Toevoorzigt betreffende het onderzoek van den staat der Koloniën en Gestichten over 1837 (verricht juli 1838 ).

203 Idem over 1838 (verricht in 1839 ).

204 P.W. Alstorphius Grevelink, Statistiek van de Provincie Drenthe, voornamelijk uit het oogpunt van Nijverheid en Volkswelvaart, met opgave der hoofd-middelen tot opbeuring van dat gewest, blz. 9 I.

205 Vriend, (xrv) I 840 , blz. 30 I e.v.

206 Staat van den Hooi-oogst in 1839.

207 Idem in $184 \mathrm{x}$.

208 Idem in $x 842$.

209 Idem in 1843 .

210 Staat van den opbrengst van het Zuivel in 1843 .

21 S Stat van de Opbrengst der Aanfokkerij, Vetmesterij en van de Wol over I 843 .

212 Staat van den Hooi-Oogst in 1844 .

213 Idem in 1845 .

214 Staat van de Opbrengst van het Zuivel in 1845 .

215 Staring en Quarles van Ufford, t.a.p., blz. I4 e.v.

${ }_{216}$ Staat van de Opbrengst der Aanfokkerij, Vetmesterij en Wol in $x 847$.

217 Staat van den Hooi-Oogst in 1847.

218 Hier bedoelde Van Konijnenburg blijkbaar de kunstweiden.

219 H. Hovius, Zomerstalvoedering, in: Landbouwdocumentatie, (17) I96r, blz. 707 e.v.; J. M. G. van der Poel, Heren en boeren, 1949, blz. 7 .

220 Staat van den Hooi-Oogst in $185 x$. 
${ }_{221}$ Staat der teveld staande Gewassen in den Zomer van 1857 .

222 Staat van den Hooi-Oogst in 1857 .

223 Algemeen Verslag over 1858 ; sinds het aftreden van de Commissie van Weldadigheid op 6 december 1856 stond de M.v.W. tot de afscheiding van de gestichten in de herfst van $18_{59}$ onder toezicht van een regeringsgecommitteerde; deze stelde de (summiere) jaarverslagen samen over I $856 \mathrm{t} / \mathrm{m} \times 85^{8}$.

224. De Star, (VII) I 825 , blz. 26 e.v.

22s Van Konijnenburg, De toestand, t.a.p., blz. 29.

226 Jongkindt Coninck, Beschouwingen, t.a.p.

227 Westendorp Boerma, Johannes van den Bosch, t.a.p., blz. 169 .

228 Hiervoor blz. 75 .

229 Verslag over de staat der koloniën door een subcommissie uit de Commissie van Toevoorzigt (o.a. Jan Kops) in: De Star, (v) I 823 , blz, 926 e.v.

230 (Wardenburg), Vlugtige waarnemingen, t.a.p., blz. 25 en 26.

23I Deze uitspraak ontleende hij aan: Hermans, Landwirthschaftlicher Katechismus.

232 Algemeen Verslag over 1840 .

233 Idem over 1843 .

234 Staring en Quarles van Ufford, t.a.p., blz. 25 e.v.

233 Algemeen Verslag over 1848 .

236 Idem over 1849 .

237 Löbnis, t.a.p., blz. 45 e.v.

BIJ HOOFDSTUK V - ENKELE SOCIALE ASPECTEN VAN DE LANDBOUWKOLONIË

I Van den Bosch, Verhandeling over de mogelijkheid, t.a.p., blz, ro3 e.v.

2 Idem, blz. 1 rg e.v.

3 Idem, blz. 142 e.v.

4 Idem, blz, $x 86 \mathrm{e} . \mathrm{v}$.

5 Idem, blz, 206 e.v.

6 Eilerts de Haan, De Noordnederlandsche landbouwkoloniën, t.a.p., blz. 33 e.v.; zie ook hiervóór blz. 48 voor een overzicht van de hiërarchische opbouw.

7 Hiervóór blz. 57 en 58.

8 Westendorp Boerma, Johannes van den Bosch, t.a.p., blz. 136 e.y.

9 Von Grouner, t.a.p., blz. 356 e.v.

ro De Star, (vi) I 824, blz. 5 r4 e.v.

II (Wardenburg), Vlugtige waarnemingen, t.a.p., blz. 26 e.v.

12 Vriend, (II) 1828 , blz. 400 ; in 1828 is voor de eerste maal sprake van de tewerkstelling van vreemde arbeiders, die niet tot de koloniale bevolking behoorden.

13 Westendorp Boerma, Johannes van den Bosch, t.a.p., blz, 139.

14 Van den Bosch, Over de inrigting, t.a.p.

15 Algemeen Verslag over 1839.

16 M.v. W., Iets over de inrigtingen, t.a.p., blz. 26 e.v.

17 Rapport Staatscommissie 26 oktober $184 \mathrm{r}$, blz. 32 e.v.

18 Algemeen Verslag over 1844 .

19 Idem over 1845 .

20 Staring en Quarles van Ufford, t.a.p., blz. 9 e.v.

2I Idem, blz. 55 e.v.

22 Idem, blz, 91 en 92.

23 Van Konijnenburg, De toestand, t.a.p., blz. 36 e.v.; Jongkindt Coninck, Beschouwingen, t.a.p.

24. Westendorp Boerma, Johannes van den Bosch, t.a.p., blz. 137; Eilerts de Haan, De Noordnederlandsche landbouwkoloniën, t.a.p., blz. 35 .

25 Vriend, (1) 1827 , blz. 598.

26 Van den Bosch, Verhandeling over de inrigting, t.a.p. 
27 Westendorp Boerma, Johannes van den Bosch, t.a.p., blz. i 89 en rgo.

28 Vriend, (XIII) I 839 , blz. 446.

30 Rapport Staatscommissie I 84I, bijl. 50 .

$3 x$ Staring en Quarles van Ufford, t.a.p., blz. 62 en 63 .

32 Idem, blz. 79.

33 Van Konijnenburg, De toestand, t.a.p., blz. 4, 30, 48 en 49.

34 Van den Bosch, Verhandeling over de mogelijkheid, t.a.p., blz. 186 e.v.

35 Eilerts de Haan, t.a.p., blz. 27 en 28.

36 Von Grouner, t.a.p., blz. 354 en 355 ; over Von Fellenberg zie: K. Guggisberg, Philipp Emanuel von Fellenberg und seine Erziehungsstaat, 2 Bände, Bern 1953.

37 J.H. van Wolda, Algemeen verslag van den staat van het onderwijs in de koloniën der M.v. W. over het jaar $\times 822$.

38 Westendorp Boerma, Johannes van den Bosch, t.a.p., blz. I 59 , 160 en 162 .

39 Vriend, (Iv) 1830 , blz. I 51 .

40 Vriend, (v) $\times 831$, Tabel, behelzende opgave van het aantal der schoolpligtige kinderen, in de koloniën der M.v.W.

4I G. Ruitenschild, Verslag over godsdienst, zedelijkheid en onderwijs in $183^{6}$, in Algemeen Verslag over $\times 83^{6}$.

42 Verslag wegens den staat van het Schoolonderwijs etc. over 184x, in Algemeen Verslag over I 84.

43 Idem over I 842 .

44 Eilerts de Haan, t.a.p., blz. 75 .

45 Staring en Quarles van Ufford, t.a.p., blz. 50 e.v.

${ }_{46}$ In 1815 stichtte Pieter Pous op zijn landgoed op het eiland Walcheren een instelling, die is betiteld als „een soort landbouwschool"; Directie van de Landbouw, De Nederlandsche landbouw in het tijdvak 18 × $3-19 \times 3$, 's-Gravenhage I $_{9}$ I $_{3}$, blz. 93.

47 Zie mijn bijdrage "De eerste landbouwschool in Drenthe” in: Nieuwe Drentse Volksalmanak, (80e jaar) r 962, Assen, blz. 23 e.v.

48 Fabius, t.a.p., blz. 59 e.v.

49 Van Konijnenburg, De toestand, t.a.p., blz. 53 .

BIJ HOOFDSTUK VI - SAMENVATTING EN CONCLUSIES; OVERZICHT

VAN DE ONTWIKKELING NA I 859

I De gegevens zijn, voor zover niet anders vermeld, ontleend aan de Jaarverslagen.

2 Verslag van het verhandelde op het xvmde Nederlandsch Landhuishoudkundig Congres, gehouden te Middelburg, r 862 .

3 Jongkindt Coninck, Beschouwingen, t.a.p.

4 Staring, Verslagen van den landbouw in Nerlerland over I 868, in : de Landbouw-Courant, 1870.

5 Bedoeld zijn de Rijksbedelaarsgestichten te Ommerschans en Veenhuizen.

6 De excursie naar de Maatschappij van Weldadigheid te Frederiksoord op 8 en 9 juni r899, in:

Orgaan der Vereeniging van Oudleerlingen der Rijkslandbouwschool, Tiel 1899.

7 G. van Leusen, Brochure over de Maatschappij van Weldadigheid, Steenwijk \pm 1930, blz. 7. 


\section{GERAADPLEEGDE LITERATUUR EN ARCHIEFSTUKKEN}

Alphonse, d', Aperçu sur la Hollande, I $\mathrm{II}$, in: Bijdragen tot de Statistiek van Nederland, nieuwe volgreeks I, I 900 .

Alstorphius Grevelink, P.W., Statistiek van de Provincie Drenthe, voornamelijk uit het oogpunt van Nijverheid en Volkswelvaart, met opgave der hoofd-middelen tot opbeuring van dat gewest, Assen 1840.

(Ameshoff, P.J.), Beschouwing van den tegenwoordigen toestand van Drenthe, in gemeenzame brieven, Amsterdam I 818 .

Beaufort, W.H. de, De woeste gronden in Nederland, in: De Gids, I 882 No. 19.

Bergh, L.Ph. C. van den, Gedachten over armoede, overbevolking en kolonisatie, Leiden 1845 .

Blink, H., Geschiedenis van den boerenstand en den landbouw in Nederland, I en Ir, Groningen 1902 en 1904 .

Boer, W. R., Denkbeelden over pauperisme en armenverzorging, Amsterdam $185^{\circ}$.

Bosch, I. G. J. van den, De excursie naar de Maatschappij van Weldadigheid te Frederiksoord op 8 en 9 Juni 1899 , Tiel 1899.

Bosch, Joh. van den, Verhandeling over de mogelijkheid, de beste wijze van invoering en de belangrijke voordeelen eener algemeene armeninrigting in het Rijk der Nederlanden, door het vestigen eener landbouwende kolonie in deszelfs Noordelijk gedeelte, Amsterdam I 8 r 8 .

- De la colonie de Frederiksoord et des moyens de subvenir aux besoins de l'indigence par le défrichement des terres vagues et incultes, van een voorwoord voorzien en in het Frans vertaald door Baron De Keverberg, Gand 1821 .

- Verhandeling over de inrigting van den landbouw, den arbeid en de administratie, 1 $83^{6}$; no. 1648 van het oud archief der (rste) Maatschappij van Weldadigheid, berustend in het Rijksarchief voor Drenthe te Assen.

Brugmans, I. J.,Paardenkracht en mensenmacht; sociaal-economische geschiedenis van Nederland I 795-1940, r961.

Colenbrander, H. T., Koning Willem r, dl. Ir, $193^{\mathrm{I}-\mathrm{r} 935 .}$

Commissie van Landbouw, Verslagen van de Commissie van Landbouw in Drenthe, I 805 -I 8 I 5 .

Directie van de Landbouw, De Nederlandsche landbouw in het tijdvak $1813-1913$, 's-Gravenhage 1913.

Eilerts de Haan, A.F., De Noordnederlandsche landbouwkoloniën, Amsterdam 1872.

- Bezoekers van Frederiksoord en hun gids, \pm r 887 .

Fabius, F. W., De Maatschappij van Weldadigheid, in hare werking, strekking en geldelijken toestand, Amsterdam 184 I. 
Gerlach,J.W.R., De vrije landbouwkoloniën der Maatschappij van Weldadigheid te Frederiksoord, Willemsoord en Wilhelminaoord, Amsterdam 1884.

Grouner, S، von, Beschreibung einer Reise durch das Königreich der Niederlande, dl. I, Passau 1826.

Have, J. van der, Kort overzicht van de geschiedenis der Maatschappij van Weldadigheid, 1904.

Heldring, O.G., Binnen- en buitenlandsche kolonisatie, in betrekking tot de armoede, Amsterdam I 846.

Hovius, H., Zomerstalvoedering, in: Landbouwdocumentatie, (17) 1961, (23) 10 juni. Jongkindt Coninck, C. J. M., Voor de lezers, die wat nader met de Maatschappij van Weldadigheid bekend willen worden, Frederiksoord 1864 .

- Beschouwingen over den Landbouw in de koloniën der Maatschappij van Weldadigheid, in: De Nieuwe Boerengoudmijn, 1865 , No. Ir.

- Twee belangrijke vragen. Vooral naar aanleiding van het laatste rapport der Financiële Commissie, Wageningen $x 877$.

Kleyn, A., Dorpen in Drenthe, Amsterdam 1949.

Konijnenburg Czn., J.van, De toestand der vrije koloniën en het instituut te Wateren bij de afscheiding der gestichten van de goederen, Meppel 1859 .

Kops, J., Etat de l'agriculture dans les Pays-Bas des Provincies Unies, I 814 t/m I828, 's-Gravenhage en Brussel i 8 I 7 - I 830 .

- Verslag gehouden door den Commissaris van Landbouw op de huishoudelijke reize van den Agent van Nationale Economie der Bataafschen Republiek, J. Goldberg, wegens den staat van den landbouw, in: Historia agriculturae, v, Nederlands Agronomisch-Historisch Instituut, Groningen 1959.

Landbouw-Courant, $1847 \mathrm{t} / \mathrm{m} \times 872$.

Leusen, G. van, The Agricultural Benevolent Institute Frederiksoord (Holland), Steenwijk r9ro.

- Brochure over de Maatschappij van Weldadigheid, Steenwijk \pm I 930.

Lier, J. H. P. van, Tegenwoordige Staat van Drenthe, 1795.

Lindemans, P., Geschiedenis van de landbouw in België, $\mathrm{I}$, Antwerpen 1952.

Linthorst Homan, J., Van kerspel tot gemeente, Assen $193^{8}$.

Löhnis, F. B., Verhandeling over de houtcultuur en de bosschen in Drenthe, Haarlem I 885 .

Maatschappij van Weldadigheid, De Star, rste tijdschrift der Maatschappij, I8I8 t/m I 826 .

- Algemene verslagen, $1818 \mathrm{t} / \mathrm{m}$ 1962.

- Reglement voor de Maatschappij van Weldadigheid, 's-Gravenhage/Amsterdam I8 8 .

- $\quad$ Algemeene staat van ontvangsten tot primo April 18 r 9 .

- $\quad$ Register, houdende aantekening van de akten van koop, ruiling en verhuur en van overeenkomsten betreffende de eigendommen der Maatschappij, met klapper, 7 juli 18 r 9-2 5 april $\times 846$, no. 922 van het oud archief der (rste) Maatschappij van Weldadigheid.

- Akten van koop, vruchtgebruik en verhuur van onroerende goederen benevens overeenkomsten, door de Maatschappij aangegaan, en brieven, daarop betrekking hebbende, 1823-1851, No. 923 van het oud archief.

- De Vriend des Vaderlands, 2de tijdschrift der Maatschappij, 1827 t/m I 842 .

- Stukken betrekkelijk de beantwoording van de brochure, getiteld: „Vlugtige waar- 
nemingen en aanmerkingen omtrent het bestaan der kolonisten-huisgezinnen in de

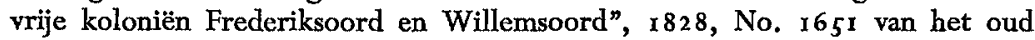
archief.

- Oogststaten, 1831-1857, no. 1141-1 443 van het oud archief.

- Stukken betreffende de classificatie der gebouwde en ongebouwde eigendommen der Maatschappij ten behoeve van het kadaster en stukken inzake vrijdom van grondbelasting, 1832 en 1833 , no. 924 van het oud archief.

- $\quad$ lets over de inrigtingen der Maatschappij van Weldadigheid in het Koningrijk der Nederlanden, 1840 .

- Verzameling van stukken nopens den stand der zaken van de Maatschappij van Weldadigheid, I 842 .

- Beoordeling van het rapport der Staatscommissie- 184 I, 1843.

- Beschouwingen over de Maatschappij van Weldadigheid, H.H.Commissarissen, 's-Gravenhage 1860 .

De toestand der Maatschappij van Weldadigheid in 1860 , H.H. Commissarissen, 's-Gravenhage I $86 \mathrm{r}$.

Beschouwingen over den tegenwoordigen toestand der Maatschappij van Weldadigheid en de middelen, die tot hare instandhouding kunnen bijdragen, Commissarissen der M.v. W. 1864 , bijlage bij de Landbouw-Courant No. 15 d.d. 14 april 1864 .

- Voorstel Löhnis tot wijziging der Statuten en adviezen daarover, 1893.

Martinet, J. F., Het Vaderland en het Verenigd Nederland, Zaltbommel 1830 .

Nederlandsch Landhuishoudkundig Congres, Verslag van het verhandelde op het vde Congres, gehouden te Leyden, den $10-14$ Juny $185^{\circ}$, Leiden $185^{\circ}$.

- Verslag van het verhandelde op het Xvir de Congres, gehouden te Middelburg, den I 7-2 I Juny I 862 , Middelburg I 862.

Oosting, W.A.J., De ouderdomsbepaling van onze bouwlanden op het plistoceen en het vraagstuk der ophooging door plaggenbemesting, in: Landbouwkundig Tijdschrift, 52 ste jrg. no. 643 , november 1940 .

Poel, J.M. G. van der, Heren en boeren; een studie over de Commissiën van Landbouw ( 1805 - 185 I), Wageningen 1949 .

Posthumus, N.W., Nederlandsche prijsgeschiedenis, 1 , Leiden 1943.

Prakke,H. J., Deining in Drenthe, Historisch-sociografische speurtocht door de „Olde Lantschap", Assen $195 \mathrm{x}$.

Provinciale Planologische Dienst van Drenthe, Beschrijving van de gemeente Vledder, Assen 1955.

Quarles van Ufford, J.K.W., De hervorming der Maatschappij van Weldadigheid, in:

De Economist, november, december 1859 en januari 1860 .

- De Maatschappij van Weldadigheid, in: De Economist, mei 1873.

Ramaer, J. C., Het Koninkrijk der Nederlanden (1815-1931), 's-Gravenhage 193 1.

Serrurier, J.F., Boerengoudmijn, Amsterdam 1807.

Slicher van Bath, B. H., Mensch en land in de Middeleeuwen, r en II, 1944.

- De agrarische geschiedenis van West-Europa (500-1850), Utrecht-Antwerpen 1960.

Staatscommissie- 1 841, Rapport van de Staatscommissie, ingesteld op 26 oktober $184 \mathrm{I}$.

Staring, W.C.H., Verslagen van den landbouw in Nederland over I 868, in: de Landbouw-Courant, 1870 . 
Staring, W.C.H. en J.K.W.Quarles van Ufford, De koloniën der Maatschappij van Weldadigheid in 1846, Arnhem 1847.

Stein, O., Pauperismus und Assoziation. Soziale Tatsachen und Ideeen auf dem Westeuropäischen Kontinent vom Ende des I 8. bis zur Mitte des I9. Jahrhunderts unter besonderer Berücksichtigung des Rheingebietes, 1936.

Ternooy Apel, J.F., Een woord ter opwekking tot het lidmaatschap der Maatschappij van Weldadigheid, Doetinchem 1885 .

Thys, I., Memorie of vertoog over het uytgeven en tot culture brengen der vage en inculte gronden in de Meyerye van 's-Hertogen-Bosch, Mechelen 1792.

Ven, F. van der, De openbare weldadigheid, Gent 1890.

Verberne, L. G. J., Geschiedenis van Nederland in de jaren $1813^{-1} 85^{\circ}$, Utrecht-Antwerpen 1958 .

(Wardenburg, B.D.G.), Vlugtige waarnemingen omtrent de ondernemingen der Maatschappij van Weldadigheid in de noordelijke provinciën van het Koninkrijk der Nederlanden, Koevorden 1828.

Wardenburg, B.D.G., Kunnen de nadeelen, met welke eene ontbinding der Maatschappij van Weldadigheid alle bij die instelling belanghebbenden bedreigt, niet afgewend worden?, Amsterdam 1857.

Welderen Rengers, W. J.van, Overzicht van het beheer der Maatschappij van Weldadigheid, na de reorganisatie van 1859,1893 .

Westendorp Boerma, J.J., Johannes van den Bosch als sociaal hervormer, De Maatschappij van Weldadigheid, Groningen 1927.

- $\quad$ Een geestdriftig Nederlander: Joh. van den Bosch, Amsterdam r $95^{\circ}$.

- Generaal Van den Bosch in Drenthe, in: Nieuwe Drentse Volksalmanak LXXI 953 (1952).

Willink, H. G., The Dutch home labour colonies, their origin and development, London I 889 .

Witlox, H., Schets van de ontwikkeling van welvaart en bedrijvigheid in het Verenigd Koninkrijk der Nederlanden, Benelux I 81 5-1830, Nijmegen $195^{6}$.

Worp van Peyma, Rapport over de landbouw in de koloniën van de Maatschappij van Weldadigheid, bijlage 52 van het Rapport der Staatscommissie-1 $84 \mathrm{I}$.

(Wybenga), De Maatschappij van Weldadigheid, in: het Nieuwsblad van Friesland, \pm 1930 . 